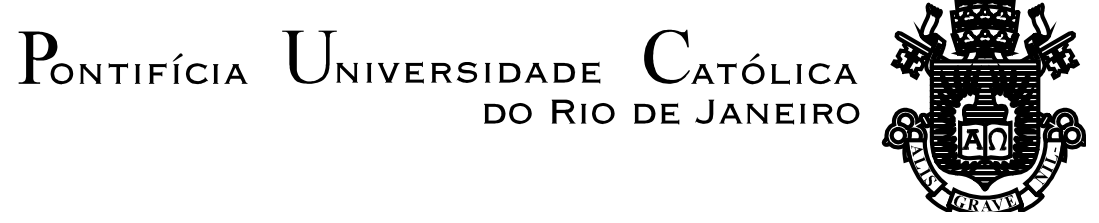

VALÉRIA FERNANDES LAMEGO

\title{
O CONTO E A VIDA LITERÁRIA DE LÚCIO CARDOSO (1930-1950)
}

\section{Tese de Doutorado}

Tese apresentada ao Programa de Pós-Graduação em Literatura, Cultura e Contemporaneidade da PUC-Rio como requisito parcial para obtenção do título de Doutor em Letras/Literatura, Cultura e Contemporaneidade.

Orientador: Prof. Júlio Cesar Valladão Diniz 
Pontifícia Universidade Católica $_{\text {a }}$

\section{VALÉRIA FERNANDES LAMEGO}

\section{O CONTO E A VIDA LITERÁRIA DE LÚCIO CARDOSO (1930-1950)}

Defesa de Tese apresentada como requisito parcial para obtenção do grau de Doutor pelo Programa de PósGraduação em Literatura, Cultura e Contemporaneidade do Departamento de Letras do Centro de Teologia e Ciências Humanas da PUC-Rio. Aprovada pela Comissão Examinadora abaixo assinada.

Prof. Júlio Cesar Valladão Diniz Orientador Departamento de Letras - PUC-Rio

Prof. Frederico Oliveira Coelho Departamento de Letras - PUC-Rio

Profa. Ruth Junqueira Silviano Brandão

UFMG

Profa. Beatriz Vieira de Resende UFRJ

Profa. Beatriz dos Santos Damasceno Instituto Superior de Ciências Humanas e Sociais Anísio Teixeira

Profa. Denise Berruezo Portinari Coordenadora Setorial do Centro de Teologia e Ciências Humanas - PUC-Rio

Rio de Janeiro, 26 de abril de 2013. 
Todos os direitos reservados. É proibida a reprodução total ou parcial do trabalho sem autorização da universidade, da autora e do orientador.

\section{Valéria Fernandes Lamego}

Graduou-se em Comunicação Social pela Universidade Federal Fluminense e obteve o título de mestre pela Escola de Comunicação da Universidade Federal do Rio de Janeiro. É autora de A farpa na lira: Cecília Meireles na Revolução de 30 (Record, 1996); organizadora de Contos da ilha e do continente de Lúcio Cardoso (Civilização Brasileira, 2012) e da Obra em prosa de Cecília Meireles (Nova Fronteira, 1997). Em 2010 recebeu o Prêmio Funarte de Literatura. Coordenou os seminários "Laboratório do Escritor", de 2006 a 2009, e "Carnaval: que festa é essa?", em 2011, e "Múltiplos e Contemporâneos: a literatura.com", em 2013. Como editora coordenou, dentre outros, o livro Impresso no Brasil (18081930): destaques da história gráfica no acervo da Biblioteca Nacional (Verso Brasil, 2009) e a coleção Cadernos de Samba (Verso Brasil, 2012 a 2015). É autora de diversos artigos, dentre eles "Dois mil dias no deserto: Maria Helena Vieira da Silva no Rio de Janeiro (1940-1947)" (MAM-SP, 2007) e "O itinerário de uma cronista", sobre a crônica em Cecília Meireles (Revista Poesia Sempre, Biblioteca Nacional, 2000).

Ficha Catalográfica

Lamego, Valéria Fernandes

O conto e a vida literária de Lúcio Cardoso (1930-1950) / Valéria Fernandes Lamego ; orientador: Júlio Cesar Valladão Diniz. - 2013.

186 f. : il. (color.) ; $30 \mathrm{~cm}$

Tese (doutorado)-Pontifícia Universidade Católica do Rio de Janeiro, Departamento de Letras, 2013.

Inclui bibliografia

1. Letras - Teses. 2. Lúcio Cardoso. 3. Modernismo. 4. Literatura brasileira. 5. Contos. 6. Crônicas. 7. Crime. 8. Vida literária. 9. Rio de Janeiro. I. Diniz, Júlio Cesar Valladão. II. Pontifícia Universidade Católica do Rio de Janeiro. Departamento de Letras. III. Título. 
Para Ivanir e Sebastião Lamego. 


\section{Agradecimentos}

Agradecimento especial a Júlio Diniz pelo apoio, dedicação e estímulo, acima de tudo.

Agradecimento a Priscila Serejo, cujo entusiasmo e apoio na pesquisa junto aos acervos foram fundamentais.

Agradecimentos aos amigos que me suportaram nos meses de escrita, a Vilmar Ledesma, Leila Lima, Cristiane Costa, Sérgio Alcides, Aydano André Motta, Flavia Oliveira, Pedro Carvalho de Miranda e Samuel Titan Jr. A Anna Paula Cordeiro, minha professora de pilates que manteve meus punhos firmes e aos herdeiros e pesquisadores de Lúcio Cardoso, principalmente, Andréa Vilela, Beatriz Damasceno, Luiz Carlos Lacerda e Rafael Cardoso. Agradeço também a equipe da Fundação Casa de Rui Barbosa, sobretudo a Laura Xavier e Leonardo Cunha do Arquivo Museu em Literatura Brasileira.

Agradecimentos mais do que especiais a toda minha família; a Ivanir, Sebastião, Mônica, Beatriz, Aninha e Vanda pelo eterno carinho e amor.

Por fim, agradeço à Editora Record e à Funarte, que subvencionaram parte da pesquisa. 


\section{Resumo}

Lamego, Valéria Fernandes; Diniz, Júlio Cesar Valladão. O Conto e a Vida Literária de Lúcio Cardoso (1930-1950). Rio de Janeiro, 2013. 186p. Tese de Doutorado - Departamento de Letras, Pontifícia Universidade Católica do Rio de Janeiro.

A partir do levantamento de cerca de 400 contos inéditos e desconhecidos do escritor Lúcio Cardoso (1912-1968) propomos uma análise e revisão de sua obra literária de 16 romances e novelas. Além disso, iremos discutir a relação do autor com o renegado realismo de seus primeiros livros, a influência do fantástico em suas novelas e contos e a difícil relação da literatura brasileira, nos anos 30, com obras não realistas. Por fim, analisaremos os mais de 265 contos dos anos 50 em que o crime e a morte são personagens frequentes, fechando o ciclo de melancolia e fracasso do mundo ficcional cardosiano.

\section{Palavras-chave}

Lúcio Cardoso; Modernismo; Literatura Brasileira; Contos; Crônicas; Crime; Vida literária; Rio de Janeiro. 


\section{Abstract}

Lamego, Valéria Fernandes; Diniz, Júlio Cesar Valladão (Advisor). The Short-Story and the Literary Life of Lúcio Cardoso (1930-1950). Rio de Janeiro, 2013. 186p. Doctoral Thesis - Departamento de Letras, Pontifícia Universidade Católica do Rio de Janeiro.

Through the surveying of about 400 unknown and not-published shortstories written by Lúcio Cardoso (1912-1968) we propose an analysis and review of his literary opus of 16 novels and short novels. Besides, we will discuss the author's relation with the rejected Realism of his first books, the influence of the fantastic in his novels and short-stories and the difficult relation of Brazilian literature of the 1930's with non-realistic works. Finally, we will analyze over 265 short-stories from the 1950's in which crime and death often appear, closing the cycle of melancholy and failure in Cardoso's fictional universe.

\section{Keywords}

Lúcio Cardoso; Modernism; Brazilian literature; Short-stories; Chronicles; Crime; Literary life; Rio de Janeiro. 


\section{Sumário}

Introdução

1. Breve introdução à recepção da obra de Lúcio Cardoso 20

1.1. Os três períodos da ficção 20

1.2. Romance de 30

1.3. O mundo pelo avesso: críticas de Jorge Amado e Mário de Andrade 33

1.4. O diabo e a busca pelo conto $\quad 46$

2. Lúcio Cardoso e o conto no Brasil (1930 a 1950) 50

2.1. Lúcio e o conto 50

2.2. De $1930 \mathrm{em}$ diante 57

3. Nasce um contista 61

3.1. Os contos gerais e os contos de crime 61

3.2. Uma ilha de melancolia, fracassos e mulheres 63

3.3. Um mar, só fuga 71

3.4. O continente fantástico 81

4. A coluna "O Crime do Dia" 90

4.1. Lúcio e Nelson: uma moeda, duas caras 90

4.2. O crime enquanto vida 96

4.3. É conto? É crônica? 102

4.4. Os 265 crimes de quase todo dia 104

4.5. A gênese da coluna "O Crime do Dia" 108 
5. Conclusão

6. Referências Bibliográficas

7. Anexos

170 


\section{Lista de Figuras}

Figura 1 - Bilhete ao editor Daniel Pereira

Figura 2 - "A mulher de Caruaru"

111 


\section{Introdução}

Revelar o que estava guardado há mais de 70 anos foi o maior objetivo desta tese, estudo e pesquisa inédita sobre o conto de Lúcio Cardoso. A partir deste esforço, descobrimos cerca de 400 contos não publicados em livro, muitos dos quais totalmente desconhecidos. A pesquisa, iniciada em 1996, e retomada em 2010, redundou na publicação de Contos da ilha e do continente (em dezembro de 2012) e, até o segundo semestre de 2013, será publicado também $O$ crime do dia, livro que encerra as edições de contos do escritor. A cada revelação e descoberta de textos sublimes, desconhecidos da literatura brasileira e jamais inseridos nas tantas antologias de contos nacionais, nos perguntávamos o motivo dessa volumosa produção ter ficado desconhecida do público leitor. O que levou o romancista e poeta a escrever tantos textos curtos e não reuni-los? Pretendemos responder a esta primeira pergunta e a outras tantas que surgiram ao longo de nosso trabalho. Teriam sido somente estes os contos que Lúcio escreveu? E quais foram as temáticas? O que os contos revelam do artista e, se revelam, onde ele inovou e como chegamos a esta produção?

Lúcio Cardoso (1912-1968), cujo centenário de nascimento foi comemorado em 2012, viveu, como seus personagens, por demais na sombra da história da literatura brasileira, apesar de seu prolongado sucesso literário dos anos 1930 ao início dos anos 1960. Precoce como a maior parte dos escritores estreantes na década de 1930, sucessores da geração modernista, lançou seu primeiro livro, Maleita, aos 22 anos. Passados 37 anos, publicou a obra considerada magistral, Crônica da casa assassinada, socialmente atemporal, recebida com ferocidade pelos mantenedores da moral, ordem e costumes sociais que regiam o final da década de $1950,{ }^{1}$ e com alguma reticência pela crítica literária. ${ }^{2}$ Escritores,

\footnotetext{
1 Artigos polêmicos e moralistas como "Romance imoral", de Olívio Montenegro (Diário de Pernambuco, 17/5/1959) e "A ilha de Lúcio Cardoso", assinado por A. L. em 28/8/1959, no Diário Carioca, geraram uma série de artigos defensores do livro e outros promovendo forte polêmica em vários jornais do país. Dentre os defensores estão Adonias Filho, Paulo Hecker Filho, Dinah Silveira de Queiroz, e outros. Na correspondência do autor, mantida pela Fundação Casa de Rui Barbosa, encontramos diversas cartas de leitores e de padres oferecendo-se para salvar a alma do escritor, tão perdida que estava ao escrever o livro em que trazia um suposto incesto e um homossexual travestido. Concluímos que a obra gerou grandes questionamentos morais, éticos, literários e, como escreveu Maurice Blanchot em seu clássico La littérature et le droit à la mort
} 
jornalistas e intelectuais, entretanto, souberam ver na obra do autor de mais outros 16 romances e novelas uma importância literária e textual incomum na literatura brasileira.

A coragem de Lúcio Cardoso em mergulhar no espírito da família patriarcal brasileira, levantando, por meio de uma rara habilidade poética empregada na prosa, o véu de moralismo e conservadorismo que cobria as vidas privada e pública, deve ser associada não somente à exposição das fraturas sociais (com seus personagens e situações insólitas transpostas com alto grau de verossimilhança), mas à sua insistência e perseverança em se manter criticamente exilado dos estilos dominantes, afirmando uma postura única na literatura brasileira. Se a Crônica da casa assassinada deu ao escritor a visibilidade e a posição definitiva e inconteste de grande autor, iremos propor aqui a leitura de peças menores, nas quais, de maneira mais resumida e enfática, o escritor manteve sua potência literária e sua forma de conceber o mundo por meio da estética, insistindo muitas vezes no quanto a política esmagava a literatura, mas, paradoxalmente, afirmando, por meio de suas lutas e polêmicas, políticas culturais e sociais, principalmente no que tangia aos seus personagens, sua abordagem e, sobretudo, sobre o que ele entendia como subversão do literário, do estético a partir do jogo político manipulador e definidor de um movimento literário social. Para inserirmos o conto de Lúcio Cardoso na literatura brasileira dos anos 1930 aos 1950 partimos primeiro, de uma leitura da recepção da obra do escritor. No Capítulo 1, propomos uma breve introdução à sua obra e, principalmente, à leitura feita pelos seus contemporâneos nas décadas de 1930 e 1940, quando dá início, também, à escrita dos contos.

Entre Maleita (1934) e Crônica da casa assassinada (1959), o escritor, nascido em Curvelo, mesorregião central de Minas Gerais, escreveu 16 romances e novelas, ${ }^{3}$ mais de uma dezena de ensaios, ${ }^{4}$ uma gigantesca obra poética,

(1949): "la littérature commence au moment où la littérature devient une question". Aqui a literatura estava oferecendo uma mudança social atordoante e cumprindo seu grande papel questionador.

${ }^{2}$ Escreve Wilson Martins: "Esta Crônica da Casa Assassinada não está longe de ser uma obraprima e os seus defeitos resultam, ao meu entender, de um excesso de literatura". Ver MARTINS, W., Um romance brasileiro. O Estado de S. Paulo, São Paulo, 1 de agosto de 1959.

${ }^{3}$ Maleita (1934); Salgueiro (1935); A luz no subsolo (1936); Mãos vazias (1938); o infantil Histórias da Lagoa Grande (1939); O desconhecido (1940); Céu escuro (1940); Dias perdidos (1943); Inácio (1944); A professora Hilda (1946); Anfiteatro (1946); O enfeitiçado (1954); Crônica da casa assassinada (1959); O mistério do MMM (1962); O viajante (obra inacabada, publicada postumamente em 1973); Baltazar (obra inacabada, publicada postumamente em 2002). 
recuperada em 2011 no livro Lúcio Cardoso: Poesia completa; 12 livros de ensaios sobre grandes figuras e assuntos da cultura brasileira, tais como Índios $e$ negros do Brasil e Machado de Assis, Castro Alves, contratados pelo Ministério da Cultura; oito peças de teatro, ${ }^{5}$ com destaque para $O$ filho pródigo, com a qual o Teatro Experimental do Negro estreou a dramaturgia brasileira em 1947; roteiros e dois filmes, um dos quais A mulher de longe (1949), inacabado e recuperado no ano do centenário pelo cineasta Luiz Carlos Lacerda; os Diários, ${ }^{6}$ escritos entre 1949 e 1962, também reunidos num único volume na ocasião do centenário.

Também no primeiro capítulo lembramos que além de escritor prolífico e contumaz, Lúcio Cardoso sobreviveu por longos períodos de sua vida como jornalista - embora vivesse vários conflitos com a profissão. ${ }^{7}$ A prática na imprensa e as dificuldades em ver sua obra inserida no meio transformou-o num feroz polemista, às vezes infeliz, ${ }^{8}$ mas, na maior parte das vezes, de uma sagacidade intolerável. Suas polêmicas com o regionalismo e os escritores do Norte, menos violentas do que as de Octávio de Faria na série de artigos publicados ao longo da década de $1930,{ }^{9}$ marcou uma cisão entre dois grupos literários: os regionalistas e um segundo grupo, cujo nome e contorno nunca foram nítidos, pois não se tratava de uma corrente estética programática, mas de tendências isoladas de autores que em sua obra permitiram que o indivíduo sobressaísse como herói e dono de seu destino, fosse ele fracassado ou tivesse sua existência ameaçada por Deus - sobre a lógica social e de movimento de massa,

É importante ressaltar que as datas aqui dispostas são do ano de publicação da obra, pois há casos de livros que foram finalizados 10, 20 anos antes desta data, como $O$ enfeitiçado, Baltazar e $O$ viajante.

${ }^{4}$ CARDOSO, L., Inventário do Arquivo, Fundação Casa de Rui Barbosa, p. 13.

${ }^{5}$ Além de $O$ filho pródigo, Lúcio Cardoso escreveu as peças $O$ escravo, A corda de prata, Angélica, O homem pálido, Os desaparecidos, Prometeu libertado e Auto de Natal. Ver em CARDOSO, L., Teatro reunido, posfácio de Antonio Arnoni Prado, Curitiba: Editora UFPR, 2006.

${ }^{6}$ CARDOSO, L., Diários, org. de RIBEIRO, E. M., Rio de Janeiro: Civilização Brasileira, 2012. Nessa tese iremos usar as duas versões dos Diários, pois no início da sua elaboração o Diários organizado por Ésio Macedo Ribeiro ainda não havia sido publicado. Por isso a convivência das duas edições, isto é, do Diário Completo, organizado por Octávio de Faria em 1970, com o atual.

7 "E quantos livros a menos são estes horríveis dias arrastados em redações de jornais, quantas obras, quantos empreendimentos, quanta glória sufocada. Nada existe de mais atroz para o escritor do que a necessidade de ganhar o seu sustento com as próprias mãos. É uma dupla condenação ao cativeiro", escreveu em Diário Completo, p. 208.

${ }^{8}$ No caso da Segunda Guerra, as polêmicas do escritor rebatendo os escritores do Norte foram muito infelizes e lhe renderam uma série de respostas.

${ }^{9}$ Ver FARIA, Octávio de, "Excesso de Norte", Boletim de Ariel, jul. 1935 citado em BUENO, Luís, Uma história do romance de 30, São Paulo: Edusp, p. 402. 
em que o coletivo ocupa o lugar do herói na narrativa, como era concebido no romance regionalista.

Viu-se nesse grupo, no qual Lúcio é inserido, a recuperação da literatura como espaço do subjetivo, onde o mundo interior dos personagens ganha relevância sobre os espaços externos. Vários nomes surgiram e algumas tendências foram relacionadas. Primeiro apareceu o conservador grupo espiritualista, fundado por Tasso da Silveira como reação ao modernismo paulista; em seguida cunhou-se o termo "literatura católica"; e, na década de 1940 em diante, teríamos o epíteto "literatura psicológica" ou "intimista". Na dificuldade e na urgência de arregimentar esses autores sob um guarda-chuva teórico e programático, os críticos do momento incluíram todos num mesmo saco, que ao longo da história da literatura foi mudando de nome, variando a tendência e os estilos. O que os mantinha juntos, entretanto, era uma reação quase natural ao romance social. Participavam dessa nova tendência escritores como Lúcio, Cornélio Penna, Octávio de Faria, Vinicius de Moraes e, anos depois, já a partir da década de 1940, Clarice Lispector. Autores que não incorporaram em sua obra o viés social do romance regional e realista, empregando, ao contrário, um subjetivismo inquietante se confrontado com a objetividade dos romances proletários - cujos autores encontravam imensa dificuldade para escrever na voz de operários e homens do campo, caindo invariavelmente num vazio expressivo. ${ }^{10}$ Numa passagem sobre o livro Salgueiro, de 1935, o segundo romance de Lúcio Cardoso, Luís Bueno comenta em Uma história do romance de 30: "Os motivadores das ações das personagens são muito remotamente sociais e mesmo a pobreza aparece menos como resultado das forças econômicas e sociais e mais como decorrência de um afastamento de Deus. Trata-se de 'um universo

\footnotetext{
${ }^{10}$ Para Luís Bueno, em Uma história do romance de 30, tanto Rachel de Queiroz, em João Miguel (1932), e Graciliano Ramos, em Vidas secas (1938), autores do romance regionalista e proletário, passaram a usar a terceira pessoa como solução para driblar as dificuldades que tinham em lidar com a fala operária ou rural em primeira pessoa, pois a tendência era que caíssem num artificialismo, aliás, situação só contornada com sucesso por Guimarães Rosa ainda na década de 1930, com Sagarana, escrita entre 1937 e 1938, porém só publicada em 1946. "Em primeiro lugar, a opção pela terceira pessoa, num gesto de abandono de qualquer tentativa de falar de dentro. Em segundo lugar, enfatizando o que há de cuidado em afastar a identificação fácil entre narrador e personagens proletários, a atitude de distanciada onisciência que se vê nesse narrador: nada daqueles comentários que encontramos em Suor (Jorge Amado, 1934), cuja função é mostrar que a voz narrativa tem um lado claro nos conflitos entre o capital e o trabalho. Em terceiro lugar, o uso do discurso indireto livre, que permite à voz narrativa, mantendo sua distância, dar voz também ao pensamento que não chega a ser verbalizado pelo personagem proletário.” Ver BUENO, L., Uma história do romance de 30, São Paulo: Edusp, p. 274.
} 
aparentado do trágico, uma espécie de Tebas vivendo sob a desgraça de um erro"". ${ }^{11}$ Salgueiro foi o último livro de Lúcio considerado regionalista, sobretudo por ele. Na história que se passa no morro do Salgueiro, no Rio de Janeiro, o autor desloca as relações sociais e as reapropria num universo local de caráter telúrico.

Ao longo de nossa busca pelo inusitado, descobrimos que ainda tínhamos um autor a ser revelado, um outro Lúcio, o dos contos. Mas, antes, fizemos uma breve introdução das suas fases literárias mais marcantes entre os anos de 1930 e 1950. Conforme realçado por Mário Carelli, autor de Corcel de fogo, estudo pioneiro da obra e vida de Lúcio, o que nos atraiu nessa pesquisa foram os momentos de "vazio curioso na bibliografia" (grifo meu) do escritor. É quando Lúcio cai do céu da literatura e encontra o inferno da vida prosaica, das redações de jornais, da rua, da cidade e do crime.

Lúcio se sente só, coberto de "cicatrizes", bebe cada vez mais. Seu mundo se torna mais sombrio. [...]. Perambula pelo bairro central (e suspeito) da Lapa, frequenta o café Vermelhinho, onde conversa com o jovem poeta Marcos Konder Reis, seu grande amigo, e sobre pintura com Santa Rosa. (Carelli, 1988, p. 66). ${ }^{12}$

Durante sete anos, de 1947 a 1953, o autor não publica livros, sendo que o único que sai a lume antes da publicação de Crônica da casa assassinada, de 1959, é a novela $O$ enfeitiçado, lançada em 1954, mas escrita anos antes, em 1947. ${ }^{13}$ Onde esteve a literatura de Lúcio Cardoso nesses anos de vazio editorial? O período é de grandes amarguras editoriais (livros recusados e fracassados), e de instabilidades de toda ordem na vida pessoal, como podemos ver no bilhete ao editor Daniel Pereira: ${ }^{14}$

\footnotetext{
${ }^{11}$ BUENO, L., op. cit.

${ }^{12}$ CARELLI, M., Corcel de fogo, Rio de Janeiro: Ed. Guanabara, 1988, p. 66.

${ }^{13}$ Em carta ao editor Daniel Pereira, Lúcio escreve: "Queria conversar com você, e especialmente sobre a 'Crônica', que finalmente tenho quase terminada na sua terceira versão. Não sei se você se lembra de uma coisa que anunciei há muitos anos, o 'Apocalipse', logo depois que publiquei 'A luz no subsolo'. Pois bem, com o correr do tempo, mudou-se ele para um 'roman-fleuve', em vários volumes, e é um trabalho que considero a minha melhor coisa, a mais bem realizada. Fiz questão de assinalar no fim de 'O enfeitiçado', que é de 1947, e que a 'Crônica' é de agora. [...]”.

${ }^{14}$ Daniel Pereira era o editor de Lúcio na José Olympio.
} 


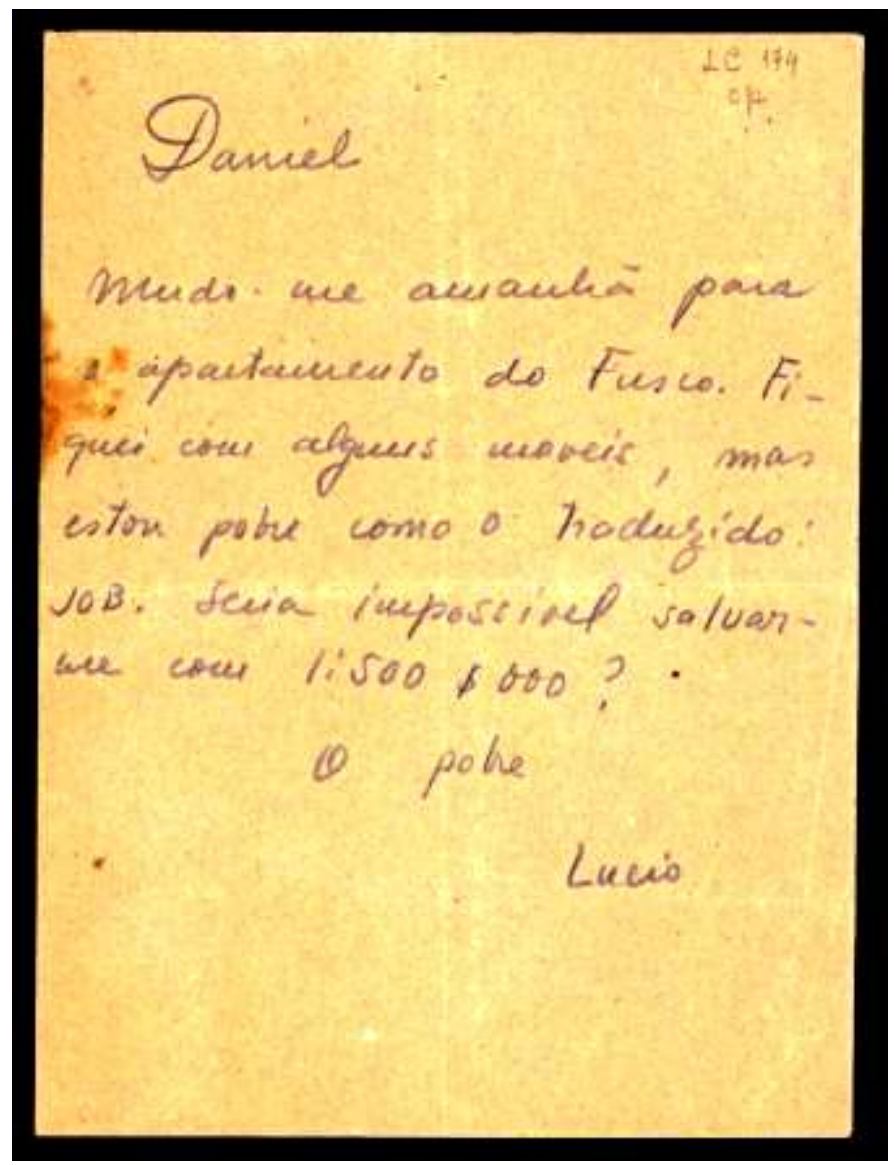

Figura 1 - Bilhete ao editor Daniel Pereira.

"Daniel, mudo-me amanhã para o apartamento do Fusco. Fiquei com alguns móveis, mas estou pobre como o traduzido JOB [BÍBLIA SAGRADA. O Livro de Job. Rio de Janeiro: José Olympio, 1943 (ilustrações de Alix de Fautereau)]. Seria possível salvar-me com 1:500\$00? O pobre, Lúcio”.

É curioso observar que em quase todos os estudos cardosianos, o personagem Lúcio Cardoso é imiscuído na análise de sua obra. Talvez o fato de o autor ter escrito um dos mais famosos diários da literatura brasileira e ter usado o gênero em sua Crônica da casa assassinada facilite a rápida transposição da persona na obra literária. Polemista, católico, homossexual assumido; morador de Ipanema, mas mineiro por religiosidade social; intimista; apaixonado e cético, Lúcio Cardoso é um dos raros autores brasileiros que não pertenceram a um mundo demarcado e de fácil reconhecimento. Flertou com o regionalismo e o abandonou raivosamente; foi autor intimista, mas lutou pelo Teatro Experimental do Negro; falou da homossexualidade claramente, mas se manteve discreto; foi conservador e fiel às liberdades. Como o intelectual latino-americano na versão de 
Silviano Santiago no artigo "O entre-lugar do discurso latino-americano", 15 acreditamos que o romancista não pertenceu a um lugar específico na plêiade da literatura brasileira. Ao contrário, esteve no entre-lugar. Assim como os mariscos resistentes, permaneceu entre a mais dura rocha e o soco das ondas, e, definitivamente, não foi um lugar confortável. De certa forma, seu posicionamento intelectual e estético o manteve e ainda o mantém pouco acessível ao leitor brasileiro.

Como detetives, nossa primeira pista foi justamente os anos de não produção, o vazio editorial, e a pergunta: onde esteve o autor de tantos romances, novelas, roteiros e peças de teatro? Teria Lúcio passado quase uma década sem contar e publicar histórias? Teria ele abandonado durante tantos anos o fio da narrativa? Quase impossível acreditar que o autor de romances tão complexos e caudalosos emudeceria por tão longo período. A segunda hipótese era, entretanto, encontrar a obra desconhecida. As pistas existiam, cerca de 20 contos foram listados pelos seus pesquisadores. Mas era pouco. Para compreender melhor o momento do conto na vida do escritor, os motivos de sua negação da obra, resolvemos fazer, no segundo capítulo da tese, uma pequena análise do conto no Brasil, sua inserção e adesão dos escritores e do público.

Nos dois capítulos seguintes, mergulhamos nas histórias curtas, no mundo de centenas de personagens tristes e apaixonantes e apaixonados do escritor. Nestes, tratamos exclusivamente da fase desconhecida do grande autor. O que fez Lúcio Cardoso durante os seis anos em que não publicou nenhum livro? Escreveu mais de 400 contos entre as décadas de 1930 e 1950. O centro de nossa análise estará nesses três importantes decênios. Parte desses contos foi recentemente publicado no livro, por mim organizado, Contos da ilha e do continente, em que 27 deles e uma novela foram recuperados. Além dos contos, as críticas e os artigos literários e algumas reportagens são igualmente desconhecidas. Parte do que foi localizado em nossa pesquisa e que faz parte do universo literário - Lúcio publicou até reportagens sobre o trânsito e a hidrologia da cidade do Rio de Janeiro, tal foi extensa sua participação na imprensa sobretudo nos anos 1950 -, publicaremos na bibliografia. Assim como incluímos no Anexo uma pesquisa

\footnotetext{
${ }^{15}$ SANTIAGO, Silviano. Uma literatura nos trópicos, Rio de Janeiro: Rocco, 1978, p. 9.
} 
sobre os crimes que ele tratou em seu diário, planilhas de análise quantitativa dos contos e alguns originais.

Os contos são todos imprescindíveis e de suma importância, mas os textos sobre crimes e sua relação, inclusive pessoal, com o submundo do Rio de Janeiro surge, aqui, pela primeira vez. A coluna "O Crime do Dia" (265 publicações) e a coluna sucessora "Novelinha do dia-a-dia" (78 publicações), não haviam recebido, até então, estudo literário ou pesquisa aprofundada. Mario Carelli apontou seu extenso trabalho sobre o crime na década de 1980, mas sem datas específicas e volume. Descobrimos também a grande relação do escritor com Nelson Rodrigues, como dividiram as mesmas obsessões, o mesmo espírito conservador sobre a mulher e como divergiam sobre sexo e o tabu. Aliás, dois personagens da literatura sobressaem nas relações de Lúcio: Jorge Amado, na década de 1930, como foi descrito no Capítulo 1, e Nelson Rodrigues, na década de 1950. Formavam um trio de grandes criadores nascidos em 1912.

Outras questões tangenciam a tese como a perquirida irrealidade de seus personagens e de suas histórias dos anos 1930 aos anos 1940. O que Lúcio entendeu como realidade? Como ele aceitou as críticas, sobretudo à novela $A$ luz no subsolo? E por que, anos depois, na década de 1950, quando se entrega totalmente às histórias de crimes, decalcadas de notícias de jornais, ele declara que todas as suas histórias são pautadas no realismo? O que mudou? No quarto e último capítulo nos dedicamos totalmente à análise dos contos de crime e não só ao estranho interesse do autor pelas histórias macabras de ficção, mas também a sua infinita curiosidade sobre a morte e todas as transgressões humanas.

Dividimos os contos do escritor em dois momentos: os contos gerais, que são tratados no Capítulo 3, e os contos de crime, no Capítulo 4. Por que contos gerais? O que define um conto geral e um conto de crime? Não são todos contos? Quantos foram e de quais períodos? Quem são os personagens? E qual o aspecto desses contos? Onde foram publicados e como foi a engenharia de descoberta? Ao contrário dos contos de crime, restritos às colunas e jornais específicos, por isso facilmente controlados, os contos gerais, embora em menor número, estiveram espalhados em uma dezena de revistas e jornais, e nossa pesquisa foi inteiramente realizada antes do lançamento da Hemeroteca Online da Biblioteca Nacional. Por fim, criamos duas tabelas (de contos gerais e de contos de crimes) a partir das 
quais analisamos percentualmente os temas recorrentes, os personagens, os cenários e a forma de o escritor narrar suas histórias sem final feliz. 


\section{1 \\ Breve introdução à recepção da obra de Lúcio Cardoso}

\section{1 \\ Os três períodos da ficção}

Para a análise da prosa de ficção de Lúcio Cardoso dividiremos sua produção em três períodos. O primeiro diz respeito aos anos de 1930, quando o autor se lança no meio literário, em 1934, com Maleita. Até meados da década manteve um flerte com o regionalismo, mas no final do período não só recusa radicalmente o gênero, como qualquer literatura de feitura realista.

O segundo período, de suma importância para o nosso trabalho, chamamos de "satânico" e ele cobre boa parte da década de 1940. De meados desta década até o início da de 1950, o autor dedica-se, sobretudo, ao conto e aos personagens de cunho fantástico. É um período pouco estudado pelas pesquisas cardosianas, uma vez que só agora esses textos, após longa pesquisa em fontes primárias, como manuscritos e jornais da época, virão a lume. Além do conto, a década de 1940 é povoada pelas novas experiências literárias do escritor, como a trilogia "O Mundo Sem Deus", formada pelas novelas Inácio, O enfeitiçado e Baltazar. É um período de mudanças e de algum silêncio editorial. Seus livros, ao contrário dos romances dos escritores do Norte, não são populares, e as vendas, fracas. É quando passa a colaborar com frequência para os jornais e revistas com textos exclusivamente literários. Desde a década de 1930 o escritor publicava invariavelmente nos jornais, mas na década de 1940 as publicações literárias se intensificam. É importante lembrar que surgem no mercado jornalístico cadernos e revistas especializadas, com destaque para o "Letras \& Artes" do jornal A Manhã, fundando em 1946. Período riquíssimo para o conto brasileiro, para a obra do escritor foi momento de transformação e amadurecimento, e nesse quadro o conto funcionou visivelmente de suporte para as novas linguagens e abordagens de Lúcio. 
Por último, temos o terceiro e, talvez, o mais rico período da obra cardosiana, que são os anos de 1950, que podem ser divididos em três grandes momentos: os anos dedicados ao jornalismo, de 1952 a 1956, quando escreveu a maior parte de seus contos de crime, matérias jornalísticas, crônicas e outros textos; o período dedicado aos diários, iniciado em agosto de 1949 e mantido até outubro de 1962 e, também, o período em que se debruça sobre o livro Crônica da casa assassinada, finalizando a década com a publicação da obra, seu último romance impresso em vida e que se tornou sua obra principal.

Sua estreia na imprensa diária se dá no jornal A Noite, em abril 1952, na coluna "O Crime do Dia". A periodicidade das publicações é quase diária, cerca de quatro a cinco textos semanais. Após "O Crime do Dia”, que termina em 1953, assina a coluna "Novelinha do dia-a-dia" e, em seguida, entre os anos de 1955 e 1956 expande seu diário para além das anotações íntimas, assinando a coluna misto de faits divers e de anotações pessoais e literárias (sempre com muita picardia) chamada "Diário não íntimo". Também no período entre 1954 e 1955 escreveu na Revista da Semana uma coluna semanal chamada "Crônica", em que discorria basicamente sobre figuras e lançamentos literários internacionais e nacionais. São essas colunas que pertencem à desconhecida fase do escritor que apelidei de "realismo jornalístico". Curiosamente, é nesse período que ele escreve duas de suas principais obras: o diário e Crônica da casa assassinada.

\section{2 \\ Romance de 30}

Adeus, o silêncio da rua é perfeito continuo insone e vagabundearei um pouco por essas calçadas desertas, seu, Lúcio ${ }^{16}$

Assim Lúcio se despede de Vinicius de Moraes numa carta escrita na década de 1930, após uma noite insone de festa. A mãe, D. Nhá Nhá, o mima com o copo de leite e o poeta segue escrevendo suas impressões ao amigo. A carta revela a mocidade boêmia, no Rio de Janeiro, errante nas calmas madrugadas de

\footnotetext{
${ }^{16}$ Carta de Lúcio Cardoso a Vinicius de Moraes, manuscrita, circa 1934-1936, AMLB, Fundação Casa de Rui Barbosa.
} 
uma cidade já tão perdida no tempo. Em 1934, aos 22 anos, Lúcio Cardoso foi considerado uma das revelações na ficção brasileira de feição regionalista com o romance Maleita. Mas não foi a prosa que o aproximou de seus primeiros amigos literários, mas a poesia. Com os poetas Vinicius de Moraes e Octávio de Faria formou uma tríade de escritores admirados pelo editor e também poeta Augusto Frederico Schmidt, o primeiro a reconhecer em Lúcio Cardoso um grande autor. Entusiasmado com sua descoberta, um jovem poeta, ficcionista, sobrinho de um empresário como ele, Schmidt apresentou a Vinicius e Octávio as primeiras poesias de Lúcio Cardoso, então apenas um rapaz que trabalhava com seu tio na firma de seguro Equitativa, ao que consta, vizinha do escritório de Schmidt.

O contentamento do poeta-editor por ter "revelado" mais um grande autor foi dividido com os dois jovens publicados por ele. A Schmidt Editora já tinha revelado algumas boas promessas literárias, como Rachel de Queiroz (João Miguel, em 1932) e Jorge Amado (O país do carnaval, em 1931). Em junho de 1934, Octávio de Faria escreve a Lúcio, depois de confirmar com Vinicius que o autor se tratava de um poeta à altura de suas leituras:

Por mais que Vinicius me tivesse falado bem do poeta nunca pensei que fosse gostar tanto. E quanto ao Schmidt, eu já o vi "descobrir" tanta pérola preta que ponho quase que sistematicamente de quarentena os entusiasmos dele. E no caso não foi certamente demais o dele - creia. (Carelli, 1988, p. 28)

Em carta a Octávio, Vinicius garantia que a poesia de Lúcio era de "grande qualidade”. E assim, de carta em carta, de revelação em revelação, teciam, além de uma grande amizade, um capítulo da história da literatura brasileira no Rio de Janeiro, à sombra de um movimento ainda sem nome e após a grande utopia da revolução modernista de 20. Para Luis Bueno, a década de 1930 questionou os ganhos do movimento de vanguarda de 1920 a partir do fracasso social e material da vida brasileira. "A arte da década de 1930 não poderá, portanto, abraçar qualquer projeto utópico e se colocará como algo muito diverso do que os modernistas haviam levado a cabo. É nesse sentido que se pode dizer que o romance de 30 vai se constituir numa arte pós-utópica" (Bueno, 2006, p. 68).

A década de 1930 foi um período de conflitos políticos e sociais que, como veremos, redundam num cenário cultural dividido entre direita e esquerda. Maleita surgiu num ano de grande efervescência literária da década, dominado 
pelo romance social e proletário. Em 1934, Graciliano Ramos lança São Bernardo, Jorge Amado, Suor, e dois anos antes Rachel de Queiroz havia lançado João Miguel. Como lembra Octávio de Faria, o jovem Lúcio era "um rapazola de mais ou menos vinte anos”. Schmidt fizera questão que Octávio o conhecesse e o "aconselhasse" (Carelli, op. cit., p. 28). A amizade entre os dois durou uma vida inteira, sendo Octávio responsável pela publicação da obra póstuma de Lúcio e da edição do Diário Completo. Ambos viam, no entanto, o mundo por lentes distintas. O conservadorismo confesso do jovem Octávio em ensaios marcadamente anticomunistas, antidemocratas e católicos, como Desordem do mundo moderno (1930); Machiavel e o Brasil (1931) e Destino do Socialismo (1932) (onde opunha cinicamente a expressão demofilia à democracia) - todos publicados pela Schmidt Editora - não contaminou nem a obra, tampouco a vida de Lúcio e Vinicius. O catolicismo, para Lúcio, como veremos, é menos um dogma moralista e doutrinário, e mais uma senha para liberdade, aceitação e compreensão dos "males" terrenos ${ }^{17}$ a partir das fábulas heroicas de um Cristo crucificado. Embora, a culpa triunfe.

O poeta Augusto Frederico Schmidt, que em 1930 criou a Schmidt Editora com o intuito de publicar somente autores nacionais - o que redundou, anos depois, num enorme fracasso (Hallewell, 2005, p. 466) -, foi tomado por uma grande admiração pelo jovem autor, contaminando positivamente parte da imprensa na época, ávida por novidades. A faina pelo novo, empreendida e alimentada pelo movimento de 22 , ainda abastecia, dez anos depois, as colunas literárias. Rachel de Queiroz, que surgiu em 1930, com apenas 19 anos, alimentou um tanto essa necessidade da literatura de jovens autores revolucionários que a partir da sua verve e potência literárias mudassem o cenário já tão revolvido e renovado pelos modernistas. "O Quinze caiu de repente ali em 1930 e fez nos espíritos estragos maiores que o romance de José Américo (A Bagaceira, de 1928, marco do romance regional) por ser livro de mulher, e o que na verdade causava assombro, de mulher nova", escreve Graciliano Ramos no artigo "Caminho de Pedras" (Ramos, s/d, p. 141). Ser jovem era uma das chaves para o sucesso. A segunda era ser jovem e dedicar sua prosa aos problemas sociais, de preferência seguindo a fórmula narrativa adotada e perpetuada por Jorge Amado em seus

\footnotetext{
${ }^{17}$ Ver CARDOSO, L., Diário, p.154-158. Aqui ele fala de alguns católicos, cita Octávio e a maneira como divergem radicalmente sobre a leitura católica.
} 
romances e na sua crítica: ${ }^{18}$ o herói não é mais o indivíduo, mas a luta de classe ou um movimento coletivo, o esvaziamento do sujeito como protagonista, uma linguagem sem excessos poéticos. O livro do jovem Cardoso foi citado em todos os jornais em 1934. A história da construção e civilização da cidade de Pirapora, decalcada da experiência paterna, gerou só nas colunas do Diário de Notícias, num período de alguns poucos dias de setembro, cerca de 5 longas críticas. Os textos, em sua maioria, destacavam a juventude do autor - alguns até diminuindo a idade para reforçar a genialidade - e a miséria humana e social relatada, além, claro, da verve poética do livro, algo raro nos escritos regionalistas do momento, que em sua maioria optavam por uma linguagem seca, descritiva e pouco lírica.

"O romance pode ser incorporado aos melhores dos últimos tempos", destaca um dos primeiros artigos, assinado por Renato de Alencar, da coluna "Editores em revista". "Maleita é um livro da observação da miséria [...]. A vida no interior do Brasil está descrita com toda a sua monotonia indolente e angustiada. Pirapora - apesar de ser nesse período - 1893 - um início de povoado, já abrigava a maledicência, a prostituição a inveja, todas as paixões turvas que convulsionam os grandes centros que foram o eterno redemoinho de ambição corroendo as aglomerações humanas, escreve o Sr. Luiz de Góngora (1934, p. 18) numa coluna chamada "Palestra masculina".

Lúcio Cardoso começou acertando com o cenário de seu romance, porque o rio São Francisco, que foi a estrada real do povoamento do Norte, caminho de civilização no meio da mata inóspita, era de há muito um convite aos nossos romancistas [...]. Maleita é um dos grandes milagres [grifo meu] do romance nacional. Livro bárbaro que revela um mundo novo iluminado por uma estranha poética [...] Maleita é uma grande agonia. Agonia da terra devastada pelo homem, agonia do homem que a sezão vai escravizando. E dentro desse sofrimento Pirapora vai nascendo, substituindo por habitações novas que se erguiam como monturos às margens do rio nas proximidades de águas imóveis, barrentas e infetas.

\footnotetext{
18 "Uma preocupação maior com a revolta das massas, o coletivo, a ausência de enredo e o fim do herói. Ao propor um romance esvaziado dessas categorias narrativas, ele (Jorge) faz um tipo de programa estético que prega o rompimento com o elemento definidor do romance burguês, ou seja, o conflito entre um sujeito como protagonista e os valores da coletividade. Se os problemas da sociedade contemporânea são derivados da luta de classes, portanto coletivos, não faria sentido pensar em como o indivíduo lida com as estruturas sociais, é preciso antes ver como as massas são exploradas pela burguesia e como elas lutam para fazer cessar essa exploração" (ver BUENO, L., op.cit., p. 165).
} 
Conta-nos Heitor Marçal no artigo "O romance de Lúcio Cardoso", também de setembro de 1934. E finaliza: "Maleita que é superior a Os Corumbas, como romance tem ainda a vantagem de ser mais bem escrito que o livro do Sr. Amando Fontes. Livro enérgico e humano como há poucos na nossa literatura" (Marçal, 1934, p. 20).

Os elogios ao Maleita prosseguem, sendo o livro indicado ao famoso prêmio literário de então, o Felipe de Oliveira, ao lado de Gilberto Freyre, com Casa Grande \& Senzala, e de Jorge Amado, com Suor. Naqueles anos, entretanto, a ascensão do romance social com ênfase no romance proletário era uma realidade, embora, como afirme Bueno, "balizas temporais para a história literária são inevitavelmente arbitrárias". O livro de Lúcio estava longe das hostes proletárias. Embora trouxesse o drama dos moradores ribeirinhos expostos às doenças e às precárias condições de vida, também trazia uma mensagem de esperança acentuada pela disposição de um engenheiro em civilizar (grifo meu) o ambiente rural, apesar de ser vencido pela natureza hostil. A tensão entre a civilização almejada pelo engenheiro (burguês), personagem na primeira pessoa, e as forças naturais do ambiente e do povo (proletário) que lá vivia não foi suficiente para Jorge Amado, na época filiado ao Partido Comunista, ver com bons olhos a primeira inserção de Lúcio na literatura.

Em 1934, Amado, que como Lúcio nasceu em agosto de 1912, já era autor de País do Carnaval (1931), editado também pela Schmidt, de Cacau (1933), e naquele ano publicava Suor, seu terceiro livro. Como relata Bueno, o ano de 1933 marca a entrada em cena do romance proletário, em que o herói, mais do que um personagem individual, é a coletividade e a luta de classe. "Não é tão absurdo ver como algo explode nos meses de julho e agosto de 1933, com a publicação praticamente simultânea de Cacau, de Jorge Amado, Serafim Ponte Grande, de Oswald de Andrade, pela Ariel, e daquele que seria considerado o grande romance do ano, Os Corumbas, de Amando Fontes, pela Schmidt. Esses três livros provocariam um grande debate em torno do romance proletário" (Bueno, op. cit., p.205). Schmidt capitaneava, até então, boa parte desses lançamentos. Mas jogava suas fichas num estreante, de origem mineira, com um primeiro romance que flertava com o movimento regionalista, embora escrito numa linguagem poética e que revelava uma relação subalterna dos ribeirinhos e moradores do povoado com um Deus ora severo, ora apaziguador. 
Segundo Bueno, o debate em torno do romance proletário rendeu até 1935 e levou tanto Os Corumbas como Cacau à condição de best-seller da década (Bueno, op. cit.). A ideia principal do gênero de romance era a de "fixar vidas miseráveis", revelar os movimentos de massas e gerar no interior da obra uma ideia de luta e revolta, perfazendo o que Walter Benjamin preconizava no mesmo período. "O escritor progressista conhece essa alternativa. Sua decisão se dá no campo da luta de classes, na qual se coloca ao lado do proletariado. É o fim de sua autonomia. Sua atividade é orientada em função do que for útil ao proletariado, na luta de classes. Costuma-se dizer que ele obedece a uma tendência”, escreve na conferência “O autor como produtor”, de abril de 1934.

Jorge Amado era o grande entusiasta do romance proletário e das fórmulas literárias que dessem voz às ideias entendidas naquele momento como progressistas, nem que com isso perdesse a sua "autonomia" como escritor. Amado empregou as técnicas em Suor, que concorria com Maleita ao título de melhor livro do ano de 1934. A preocupação com a revolta das massas e com o coletivo, o fim do herói e, sobretudo, a abolição do enredo eram alguns dos ingredientes importantes à narrativa proletária. Suor, entretanto, encontrou na crítica conservadora fortes opositores que consideraram os palavrões citados ao longo da obra como gratuitos, o que fez com que a venda fosse até suspensa por um período (ver Bueno, op. cit.). Mas a fúria de Jorge se voltou, entretanto, contra Maleita. Recebido com grande alvoroço pela crítica, tinha um apelo social, buscava na linguagem uma aproximação - embora artificial - com o sertanejo do interior mineiro e a prevista luta de classes, mas com a devida proximidade com a religião e o sobrenatural, como podemos observar neste trecho (Cardoso, 2005, p. 119):

- Nhozinho tenha pena de mim... Não me deixe só, eu morro, nhozinho!

Tinha pavor à calada da noite e falava de almas do outro mundo. Como se convencesse de que nada me faria voltar para trás, pediu a Deus que o fulminasse, em grandes gritos que encheram o povoado.

Como o céu e os homens permanecessem indiferentes, implorou que ao menos deixassem junto dele uma lamparina.

A sombra, o mistério, a noite, apavoravam-no.

$\mathrm{Na}$ voz do engenheiro, que "tem pena" do pobre negro fugitivo, Deus é igualmente temido. 
A recepção de Maleita por Jorge Amado, em artigo para $O$ Jornal, foi o primeiro ataque do escritor baiano à obra de Lúcio Cardoso. Naquelas linhas, começava lentamente, cozinhada em fogo brando, a disputa entre escritores do Norte e os "ditos" intimistas.

A Maleita com sua febre e o seu frio é o personagem desse romance de Lúcio Cardoso. Ou melhor, é a espinha dorsal do livro, o eixo em torno do qual ele gira. No entanto, há um momento em que a bexiga aparece. E como certos filmes nos quais um extra rouba os olhares da platéia, que deviam se dirigir ao ator principal, a bexiga toma conta do romance, se coloca num plano importante e domina 3 ou 4 capítulos. E esses capítulos, da bexiga, são sem dúvida os melhores do romance do jovem mineiro. [...] E temos em Maleita um romance? [...] Maleita não é apenas narrativa com belas paginas de poesia. É romance e romance bem feito.

$$
* * *
$$

Há no momento uma bruta confusão de valores dada a avalanche de livros que surgiram ultimamente. E já se destacar dessa confusão um livro, é prova do seu valor. É o que acontece com Maleita. [...] Talvez seja um defeito de Maleita como romance: a sua intensidade poética que atrapalha um pouco a densidade dramática do romance e chega às vezes a criar confusão. Eu prefiro o livro com esse defeito. Se o drama perde, ganha o ambiente (o rio, a Maleita, a bexiga, Pirapora) uma força que o anima e os faz viver.

Sem esse hálito tão forte de poesia, talvez ficasse mais seguro o drama do homem que foi construir uma cidade no sertão e perdeu tudo, desde a esposa até a saúde. Possivelmente o romance ganharia em construção, se fazendo mais sólido, com uma continuidade mais segura. Porém duvido que tivéssemos então, o belo livro que é Maleita, meio largado, feio por construir, mas com algo de epopéia, com alguma coisa de novo e de inédito.

***

No mais não sei onde se possa pegar para negar Maleita como romance. E até os mais ordeiros livros, que pouco se afasta dos moldes clássicos do romance, mesmo nesse ano de 1934, depois das novidades que Rachel de Queiroz trouxe em João Miguel e José Lins em Menino de Engenho.

Ainda um romance branco, romance de simples literatura, o que é uma pena. Note-se, no entanto, uns quadros fortes como o da pescaria com os homens nus, de repente atrapalhados no seu trabalho honesto pela voz do capitalismo que vem chegando com a moral e um chicote. E em nome daquela, com a força deste, obriga os homens a se vestirem.

Sei que Lúcio Cardoso não pretende parar nesses romances catolizantes. Sei que irá mais adiante, mesmo porque a sua extraordinária força de romancista não se pode perder em simples livros sem outra finalidade que divertir leitores gordos e ricos. (Amado, 1934, p. 1, grifos meus) 
Jorge Amado foi dos poucos a analisar criticamente o romance do jovem Lúcio. Num texto dúbio, que ora discorda, ora concorda sobre o mesmo tema e, sobretudo, sobre a forma poética que o autor deu à narrativa regionalista, encontramos na crítica de Amado uma tentativa de trazer o jovem para o círculo dos autores de esquerda, pois embora Maleita se tratasse de um romance claramente social, não era politicamente de esquerda. Pelo contrário, o autor de Suor viu no romance uma tendência catolizante. As críticas são fortes: "romance de simples literatura", "romance para divertir leitores gordos e ricos", "romance com hálito de poesia". E o mais grave: "catolizante".

Ser católico, nos anos 1930, era uma postura política. Além do modernismo continuador, sem rupturas, pregado por Alceu Amoroso Lima - o grande crítico católico - e por toda a hoste de escritores católicos, o grupo era contrário a toda filosofia de vanguarda empreendida pela Semana de 22. O modernismo continuador foi ideia defendida por Amoroso Lima, no círculo de autores da revista Festa (ver Caccese, 1971, p. 64; Rodrigues, 2009) - que pregava o conservadorismo literário e moral, e o fim das ideias comunistas e coletivas dos autores do realismo socialista que tanto faziam sucesso naquele período.

Para Darcy Damasceno (1958, p. 21), os católicos previam a renovação da literatura brasileira "na base do equilíbrio e do pensamento filosófico". E neste aspecto produziam um modernismo bem diferente daquele divulgado por Mário de Andrade e Oswald de Andrade. Para Mário, o movimento modernista foi "uma revolta contra o que era a Inteligência nacional" (Andrade, M., s/d, p. 235). O grupo espiritualista oferecia à cultura brasileira a versão conservadora de um movimento modernista, sem rupturas com as tradições anteriores - simbolista e romântica - e sobretudo sem "revolta". As ideias deste grupo vêm se firmar no cenário literário carioca a partir do lançamento da revista Festa, em 1927, e tinha como um dos próceres, claro: Alceu Amoroso Lima.

A revista Festa apresentou uma série de alternativas ao entendimento sobre a modernidade e a ideia de Nação formuladas pelos modernistas do Rio de Janeiro, principalmente durante as desbravadoras experiências estéticas da década de 1920. O nome da revista, inspirado na obra A Festa Inquieta, de Andrade Muricy, é justificado pelo autor como uma remissão a uma forma de alegria que vence a dor. A revista foi publicada em duas fases, o primeiro número surgiu em agosto de 1927, no Rio de Janeiro, e teve larga divulgação e distribuição, principalmente na Livraria Católica e no Centro da Boa Imprensa. A publicação foi interrompida em 1929 e retomada para uma segunda fase entre 1934 e 1935 . Teve como principais 
colaboradores, além de Tasso da Silveira, Ronald de Carvalho, Andrade Muricy, Jackson de Figueiredo (apenas na primeira fase), Alceu Amoroso Lima, Afrânio Coutinho, Murilo Mendes, Henrique Abílio, Cecília Meireles, Ribeiro Couto, Manuel Bandeira, Adelino Magalhães e Adonias Filho. De longe a colaboração vinha de Mário de Andrade (São Paulo) e Rosário Fusco (Minas Gerais). A primeira fase, com o nome de Festa: mensário de pensamento e de arte, representou seu período mais importante, já que por ter sido publicada ainda na década. (Rodrigues, op. cit., p. 111)

Para Leandro Garcia Rodrigues, estudioso da obra e pensamento do católico Amoroso Lima, na década de 1930 intelectuais da esquerda pregavam que os "pensadores da direita não tinham qualquer tipo de sensibilidade social e ignoravam profundamente o que estava acontecendo na realidade brasileira daquele momento". Para justificar, ele cita o artigo "A Esquerda e a Direita Literária”, publicado no carioca Boletim de Ariel, em agosto de 1935, assinado por Miranda Reis, que constata:

\begin{abstract}
O palco literário tem, portanto, uma direita e uma esquerda. A família literária está desunida, dividida, bipartida. Há, dentro dela, duas tendências contrárias, dois partidos adversos e não há como furtar-se a gente a uma posição definida, sem incorrer na pecha de oportunista. Enquanto a esquerda insiste no primado do social, a direita sobrepõe ao sentido do social o sentido do humano: que, enquanto a esquerda prega misticamente a revolução, a direita descobre "a verdadeira mística"; que, enquanto a esquerda deblatera contra as desigualdades e as injustiças sociais, contra a exploração do homem pelo homem, a direita perscruta o "verdadeiro sentido da vida" e se perde em particularidades, em profundidades, em densidades, em superposição de planos e outras sutilezas; que, enquanto a esquerda critica os preconceitos sociais, a direita, emprestando a um não-sentido, a uma imbecilidade, um sentido profundo, alude ao "preconceito de não ter preconceito". (id., p. 110).
\end{abstract}

Diferenças ideológicas, oposições estéticas e filosóficas dividiam o cenário da literatura brasileira e, desde então, essa polaridade permaneceu simbolicamente colada às paredes da cultura brasileira. Em 1934, ter um livro "acusado" de catolizante poderia ser desestabilizador para um jovem escritor. Tanto que no mesmo período o editor Augusto Schmidt, da Schmidt Editora, suprimiu o nome "católica" de sua livraria, que antes de "Schmidt Livraria e Editora" era "Livraria Católica" (Hallewell, op. cit., p. 468). Com o novo nome pode apostar tanto na literatura e ensaios conservadores de padre Leonel Franca, como na nova safra de autores preocupados com as questões sociais brasileiras e claramente de esquerda. 
A saudável turbulência do período não afetou a decisão literária de Lúcio Cardoso, que no ano seguinte à publicação de Maleita surge com Salgueiro, livro também em tons regionalistas que se passa no morro homônimo, na Tijuca, bairro que conheceu na sua infância. Salgueiro é um livro curioso e que acendeu a ira de Jorge Amado pela segunda vez. Traz um universo que poderia ser cenário de qualquer obra de cunho social, mas sobrepõe os conflitos individuais dos personagens sobre os problemas coletivos. Na crítica de Luís Bueno, Salgueiro traz em si uma oposição ao romance proletário.

Haverá muito da intenção de fazer uma oposição (grifo meu) ao romance proletário no projeto de Salgueiro, já que ali Lúcio Cardoso faz uma apropriação por assim dizer espiritualista do universo social habitualmente explorado por ele. Há mesmo uma marca realista no livro, em que a miséria física aparece descrita de forma econômica, mas ainda assim bastante crua. A pobreza dos barracões, a condição ainda pior daqueles que moram na parte superior do morro, o recrutamento de mulheres para prostituição, o sistema de exploração dos alugueis, o desamparo dos operários que adoecem: tudo isso tem função relevante no desenvolvimento do enredo. (Bueno, op. cit., p. 275)

Discordo quando o autor fala de oposição ao romance proletário, preferindo apontar Salgueiro como um livro de transição, de um jovem autor que chegava à literatura com um cabedal enorme de leitura de escritores como Dostoiévski, Julien Green e outros, para os quais os dramas individuais e a profundidade de seus personagens sempre foram mais relevantes e superiores do que o cenário e as questões meramente sociais. Além disso, é inegável a influência da crítica católica, embora Lúcio Cardoso não tenha feito parte do grupo católico da literatura. É bom ressaltar que o morro do Salgueiro, na Tijuca, era apresentado na imprensa diária como lugar violento, onde uma série de crimes e suicídios acontecia regularmente, além de ser palco de muita pobreza. ${ }^{19} \mathrm{E}$ foi na Tijuca que o escritor passou boa parte de sua infância e adolescência, chegando ao bairro em 1923, quando ainda era chamado de Aldeia Campista (Carelli, op. cit., p. 24).

\footnotetext{
${ }^{19}$ Em 14 de junho de 1935, uma manchete na capa do Diário de Noticias, "O Salgueiro em polvorosa", anunciava conflito entre vários moradores após um culto religioso; homens e crianças foram feridas, houve tiroteio e correria. Em 13 de maio do mesmo ano, A Manhã estampava a seguinte notícia na primeira capa: "Morro do Salgueiro: pedaço da Índia dos párias na 'Cidade Maravilhosa'. A reportagem de A Manhã visita a população mais abandonada da capital brasileira".
} 
Jorge Amado, no entanto, vê o novo livro de Cardoso como um libelo oportunista. Até porque, Suor, escrito no Rio de Janeiro, publicado no mesmo ano pela editora Ariel, ${ }^{20}$ concorrente da Schmidt, onde o baiano iniciou sua vida literária, tinha como cenário a vida numa parte pobre, favelizada do Pelourinho em Salvador, onde teria morado aos 16 anos para vivenciar a experiência proletária.

Amado, entretanto, mescla poucos elogios com uma crítica devastadora: "grande romancista", "grande poeta", mas o que "estraga o romance são outras coisas", escreve no artigo de junho de 1935, cujo título "Octávio de Faria no Morro de Salgueiro" já é abertamente uma declaração de guerra a Lúcio, aos católicos e ao que era chamado de romance burguês. Amado destrói o livro de Cardoso, que na sua visão não atendia a nenhum critério do romance social, além de usurpar o cotidiano dos moradores do morro do Salgueiro e colocar Deus numa narrativa que tinha como cenário a pobreza e os problemas sociais. A violência de Amado dá uma noção dos graves conflitos literários pelos quais passava a literatura brasileira nos anos 1930 .

\begin{abstract}
Não sei de título menos oportuno que este de "Salgueiro" dado pelo Sr. Lúcio Cardoso ao seu último romance [...] ele botou tipos intelectuais, botou os seus conhecimentos de bancada de café com a suas tremendas discussões espiritualistas no morro do Salgueiro. Personagens bem levantados, porque vivem por conta própria porque o Sr. Lúcio Cardoso é um romancista, ambiente bem descrito, mas os personagens falsos dentro do ambiente, desligados inteiramente deles. E como se num romance de psicologia o romancista colocasse índios do Amazonas de casaca em bailes dos Cassinos do Rio, sem dizer a ninguém que eles vieram das margens do Amazonas [...]. O sr. Lúcio Cardoso colocou no morro do Salgueiro o Sr. Octávio de Faria e outros senhores e senhoritas que continuaram lá as intermináveis discussões que vem tendo há cinco ou seis anos sobre a existência de Deus e o valor do Sr. Tristão de Athayde... Ora, estes senhores, principalmente estas senhoritas, não estão acostumadas ao ambiente das misérias do grande morro dos sambas e das navalhadas do Rio de Janeiro. Se sentiram realmente mal naquele ambiente e estragaram um romance...

A prova disso é que todo diálogo do Sr. Lúcio Cardoso é de uma falsidade desoladora [...].

Também não foi um homem do Salgueiro que recebeu Deus em língua de fogo, de repente, quando todo o ambiente o levaria a receber coisa muito diversa se este romance fosse em verdade um romance dos moradores do morro do Salgueiro. O Sr. Lúcio Cardoso aplica Deus ao seu personagem como certos médicos aplicam pastilhas ao seu doente. Depois vem o Sr. Octávio de Faria e bate palmas... Parece até o Sr. Amoroso Lima relatando a sua conversão... [...].
\end{abstract}

\footnotetext{
${ }^{20}$ A editora Ariel, que iniciava naquele ano suas atividades, tinha como um dos sócios o temido crítico literário Agripino Grieco.
} 
Tão falso que o romancista jogou mal a cartada e não soube explicar a penetração de Deus no seu herói. [...] os moradores do Salgueiro podem protestar. Eles não estão fotografados no romance de Lúcio Cardoso. Por isso mesmo um literato perverso me dizia que o livro do Sr. Lúcio Cardoso devia ter o título de Metrópole $^{21}$ e não de Salgueiro. (Amado, 1935, p. 3)

Para Luis Bueno, Amado e Cardoso buscavam em suas obras a mesma questão: a liberdade como meio para alcançar a utopia, sendo que o baiano recorre à revolução social, enquanto o mineiro, segundo o ensaísta, a Deus (Bueno, op. cit.). Em busca ou não de uma utopia para construir o sentido do mundo por meio da literatura, é fato que Lúcio Cardoso sugere em Salgueiro uma literatura em que os personagens vivem por meio de violentas experiências de ódio e dramas profundos na miséria a que foram relegadas. Não há na narrativa esperança possível. E sobra um gosto de fracasso e sofrimento.

Curiosamente, a crítica de Amado que apontava a inverossimilhança dos personagens cardosianos e a fragilidade narrativa do autor sobre a pobreza, da qual ele não fez parte, é a mesma crítica que recebe de Francisco de Assis Barbosa, em 1935, no artigo "O imperador Jones da Bahia", publicado na ocasião do lançamento de Jubiabá:

O autor de Jubiabá preocupado como anda de fazer literatura social, cai na insinceridade para com a vida. Ora, eu acho que o escritor tem que seguir um sentido talvez mais do que objetivo. Criar homens verdadeiros, dentro do drama da vida. O senhor Jorge Amado, no seu furor criador, não teve dúvida: deformou os homens. A pessoa que tem uma feridinha no pé, para ele virou leproso. Todas as prostitutas são anjo. Todos os ricos são maus e todos os pobres bons (este contraste foi a coisa mais chocante de Cacau). (Barbosa, 1935, p. 19)

Muitos anos depois a obra de Jorge Amado recebeu críticas ainda mais contundentes, e que levavam em conta as mesmas críticas feitas por ele a Cardoso:

\footnotetext{
${ }^{21}$ Jorge Amado certamente estava se referindo à seguradora Metrópole: Companhia de Seguros Gerais onde Lúcio trabalhava e que tinha dentre os membros do conselho fiscal Alceu Amoroso Lima.
} 
Os críticos apontam como defeitos persistentes na obra de Jorge Amado:

1. falta de complexidade interior nas personagens

2. linguagem pouco trabalhada, ausência de experiências formais, construção romanesca e técnica nos moldes tradicionais.

3. ação por vezes emperrada pelo discurso (geralmente poético). (Lucas, Fabio, apud Bueno, 2006, p. 176)

\section{3 O mundo pelo avesso: críticas de Jorge Amado e Mário de Andrade}

No ano seguinte, em 1936, Lúcio Cardoso radicaliza e lança o intimista $A$ luz no subsolo (1936), que levou Mário de Andrade a repensar a literatura regionalista daquele momento, e, apesar de considerar a leitura penosa e difícil, confidenciou ao jovem escritor: "seu livro me fez percorrer escalas de vaidade pessoal, de esforço de compreensão, de desejo de gostar, de prazeres reais e de impossibilidades pessoais de acertar". ${ }^{22}$ Se o escritor e crítico paulistano reconheceu que havia um sopro de novidade no romance, uma literatura até então não realizada no país, também não poupou críticas.

A luz no subsolo foi um dos livros mais atacados da obra de Lúcio Cardoso e um divisor de águas em sua bibliografia, como observa Mário Carelli em Corcel de fogo: vida e obra de Lúcio Cardoso (1912-1968), estudo pioneiro e que serviu de fonte a todos os estudos atuais. As críticas ao livro só não se comparam às de Crônica da casa assassinada, lançado 23 anos depois. Os ataques ao hermetismo de $A$ luz no subsolo vieram, sobretudo, da incompreensão em relação à inverossimilhança num momento em que o realismo social ainda era fundamental para o intelectual-escritor brasileiro, enquanto as críticas à Crônica da casa assassinada são ecos de um moralismo decadente.

A primeira grande incompreensão vem, como mencionado, de Mário de Andrade, numa carta com severas implicações que poderia levar um jovem autor à desistência, se não fosse a confiança de Lúcio em sua literatura e, sobretudo, na aderência positiva e entusiasmada de um grupo de amigos, leitores e "lucistas", como os apelidou Octávio de Faria. Na devastadora crítica de Mário, as últimas

\footnotetext{
${ }^{22}$ ANDRADE, M., em Correspondência pessoal no Arquivo de Lúcio Cardoso, Fundação Casa de Rui Barbosa, LC 13, cp.
} 
linhas não deixam dúvida quanto ao seu parecer: o livro tinha sido um erro, aos seus olhos. "Acho besta profetizar, parece que estou consolando você dum livro errado! Quando não tenho elementos meus pra garantir que você errou!...”. Mas, ao mesmo tempo, Mário dá uma chance à dúvida. Teria sido realmente um erro aquele universo tão diferente de tudo que vinha sendo publicado até então? Ou era o novo mais uma vez?

São Paulo, 20 de agosto de 1936.

Lúcio Cardoso.

Muito obrigado pelo envio da "Luz no subsolo". Que romance estranho e assombrado você escreveu! Já tinha começado a ler ele, quando recebi o presente, e agora ajunto este a minha vaidosa coleção de "exemplar dedicado e não cortado" que guardo junto ao exemplar cortado, lido e anotado. Quase sempre anotado. Este seu não anotei. Me deu um bruto soco no estômago, fiquei sem ar, lia, lia, o caso me prendia, os personagens não me interessavam, às vezes as análises me fatigavam muito, às vezes me iluminavam, não sabia em que mundo estava, inteiramente despaisado. Falar que gostei do seu livro, não seria propriamente uma insinceridade. Seria muito mais vaidade de escritor já da segunda linha e que quer bancar o conhecedor up to date. Achei seu livro absurdo porque os personagens me pareceram absurdos. Tanto no Brasil como em qualquer parte do mundo. E não me pareceram, não cheguei a senti-los como personagens do outro mundo. Loucos? Aberrados de qualquer realidade já percebida por mim? Ou antes, criaturas exclusivamente criadas pelo autor pra demonstrar a sua percepção subtil e pra mim um bocado confusa (não compreendi exatamente) da luz no subsolo? Tive mais a sensação que se tratava deste último caso.

$\mathrm{E}$, no entanto, não gostando do todo, não me interessando os personagens, não vivendo muitas das análises, não percebendo muitas das reticências, gritos, medos, gestos: apesar de tudo, fui até o fim, preso, lendo horas seguidas. É verdade que esta prisão ao livro deriva em parte duma curiosidade falsa: esse desejo que dá às vezes, romanticamente, de saber o que vai acontecer pros personagens. Mas nesse caso é que os personagens viveram dentro de mim!...

Seu livro é um forte livro, artisticamente me pareceu ruim. Socialmente me pareceu detestável. Mas compreendi perfeitamente a sua finalidade de repor o espiritual dentro da materialistica literatura de romance que estamos fazendo agora no Brasil. Deus voltou a se mover sobre a face das águas. Enfim, é possível que você tenha agido um pouco nazisticamente, ou comunistamente demais. Quero dizer: viu por demais a tese, teve o desejo de agir de certo modo, e abandonou por essa norma de ação e intenção, arte e realidade.

Também senti o esforço pessoal de não marcar passo, transformasse completar-se. Também aplaudo isso violentamente.

E assim fiquei. Você perceberá pela sinceridade desta carta que seu livro me fez percorrer escalas de vaidade pessoal, de esforço de compreensão, de desejo de gostar, de prazeres reais e de impossibilidades pessoais de acertar. Mas me prendeu. Livro ruim, livro bom: sou incapaz de decidir. Mas que é a abertura de uma coisa nova pra nós, uma advertência forte, é incontestável. E você, cristalizado nesse caminho que abriu, quando as suas intenções forem menos ostensivas e o seu amor dos homens e da vida voltar, dominando a intenção, você não sei, não sou profeta, acho besta a profetizar, parece que estou consolando você dum livro errado! Quando não tenho elementos meus pra garantir que você errou!... 
Um grande abraço ${ }^{23}$

Mário redimiu o livro "errado", pelo acerto de introduzir o "espírito" na literatura brasileira. "Socialmente me pareceu detestável (grifo meu). Mas compreendi perfeitamente a sua finalidade de repor o espiritual dentro da materialística literatura de romance que estamos fazendo agora no Brasil. Deus voltou a se mover sobre a face das águas". Suas dúvidas em torno dos personagens loucos, aberrados, despaisados, e sua falta de serventia pareciam mais fortes do que o intuito do escritor em reposicionar-se dentro da literatura e, por meio de seu próprio romance, abrir radicalmente um novo caminho e possibilidades narrativas. Como bom crítico e intelectual perspicaz, Mário, antes de cravar no peito do autor a pecha do erro, coloca-se como um mau crítico, incapaz de se aventurar naquela terra desconhecida: "Livro ruim, livro bom: sou incapaz de decidir".

Chamado pela imprensa, Lúcio explicou seu novo livro, suas escolhas por personagens enlouquecidos, sua decisão em tratar das aflições humanas e sua postura diante do realismo de então. E A luz no subsolo gera, pela primeira vez na década de 1930, os sinais incipientes de esgotamento do romance social. Numa longa entrevista ao jornalista curitibano Newton Sampaio - de formação católica - o título da matéria, "Caminho do espírito no Brasil de Lúcio Cardoso", ilustra a tendência da conversa com o autor de Maleita:

\begin{abstract}
Não há nada a explicar em A luz no subsolo fora do que está dito no próprio livro. Sinto-me um pouco surpreendido com toda esta confusão; mesmo o título, é explicado por um dos personagens [...]. Sou insistentemente acusado pelos críticos de criar personagens trágicos e histórias sombrias, sem simplicidade, onde ninguém vive normalmente. Para os outros todos aqueles personagens padecem de sofrimentos imaginários. Ninguém pode acreditar naquilo que nunca sentiu; estes nunca padeceram dessas preocupações e julgam irreais as preocupações dos outros. Cada um vê a vida através da sua natureza. (Sampaio, 1936, p. 3)
\end{abstract}

A luz no subsolo foi mal recebida pela crítica e teve pouquíssima repercussão na imprensa, mas o descontentamento do mainstream literário com as obras de Lúcio, no final de 1930, não termina com o romance. Em 1938, quando

\footnotetext{
${ }^{23}$ ANDRADE, M., Arquivo-Museu de Literatura Brasileira (AMLB), Fundação Casa de Rui Barbosa. LC $13 \mathrm{cp}$. (grifos meus).
} 
lança Mãos vazias, sofre novas críticas, e desta vez sem afagos. Manuel Bandeira é duro com o autor e não vê espaço na literatura brasileira para um romance “inverossímil”.

Não entendo porque você foi colocar esse drama de ação todo numa cidadezinha do interior S. José das Almas. Por intenção simbolista? Mas isso cria um disparate que chega a ser cômico. A maioria dos pequenos episódios não podia passar-se num lugarejo daqueles. ${ }^{24}$

Tanto Bandeira como Mário de Andrade urgem por verossimilhança na nova obra do escritor mineiro, que abandona totalmente o aplaudido realismo "poético" de Maleita e Salgueiro para entrar num túnel obscuro, de personagens alegóricos, que mais se assemelham a figuras oníricas do que a seres palpáveis em voga naquele momento de construção de uma obra identificada politicamente com apelos nacionalistas. Os romances de estreia receberam os maiores elogios dos críticos, sobretudo de Agripino Grieco, temido por jovens escritores e editor da Ariel, concorrente da Schmidt no espaço da nova literatura brasileira.

A luz no subsolo e Mãos vazias são os primeiros livros em que Lúcio Cardoso desbrava o mundo sombrio, intimista, de indivíduos apagados, distante de uma coletividade realista e destinados ao fracasso. É nesse teatro de sombras e dúvidas em que deságua, na década de 1940, sua literatura incompreendida pelos seus pares, mas aplaudida por uma nova geração de escritores residentes no Rio de Janeiro, como Clarice Lispector e Fernando Sabino.

\section{Polêmicas à vista}

Apesar das críticas, não desiste de ficar na contramão. Numa desajeitada entrevista ao crítico e jornalista Brito Broca $\left(1938^{25}\right)$, justifica suas escolhas e

\footnotetext{
${ }^{24}$ BANDEIRA, M. Correspondência para Lúcio Cardoso, em 17 de janeiro de 1939, Fundação Casa de Rui Barbosa, LC24 cp.

${ }^{25}$ Um ano antes, em 1937, ele teria se envolvido numa luta corporal como José Lins do Rego que, por sua vez, teria chamado Octávio de Faria de "carola". A discussão ia alta entre um grupo contra e a favor do novo romance de Octávio de Faria, Mundos mortos, de 1937: "É formidável. Sim, o romance do Octávio é formidável. Mas o Sr. José Lins do Rego não julgava assim, e atacara-o barbaramente. Ah! Chamava o Octávio de Faria de "fascistóide", sim senhor, de "fascistóide". [...] Chegava à livraria o romancista Lucio Cardoso. Eis senão que com os olhos vidrados de ódio, o Sr. Lins do Rego fixa o autor de Maleita e fala:

- Cambada de carolas, carolas! Carolas! ...
} 
ataca ferozmente Jorge Amado. A luz no subsolo, segundo ele, foi um processo de renascimento e renovação de sua literatura: "Foi o livro em que fixei a minha orientação de romancista, desfazendo-me completamente da observação", diz, referindo-se aos primeiros livros.

Neste artigo, Brito Broca analisa A luz no subsolo como um livro incômodo para o meio literário, incompreendido e atacado. $\mathrm{Na}$ entrevista fica clara a dificuldade do escritor em falar da obra rejeitada, que teria sido o primeiro volume da trilogia A luta contra a morte, que não foi completada. A trama, desse que foi um dos romances mais incompreendidos da historiada literatura de 30, era sobre um casal em crise e dois homens que disputavam a mesma mulher. Diante do romance social do período, dos personagens proletários e heróis lutando por justiça social, o novo livro de Cardoso trazia um cenário decadente burguês, sufocado por decisões pessoais e por personagens que lutavam pela supremacia de suas individualidades. $\mathrm{O}$ crítico insiste em falar no livro. $\mathrm{O}$ escritor que lançava naquele ano o seu quarto romance, Mãos vazias, é taxativo: “creio que não vale a pena tratar de A luz no subsolo".

É a partir do livro rejeitado pela crítica - refletido numa fortuna crítica pífia - que o autor se decide pelo escritor que hoje conhecemos. Mesmo com a adversidade de seu tempo, em que tanto escritores como críticos se guiavam pura e simplesmente pelas questões nacionais urdidas nas páginas literárias, ele trouxe o drama e "o clima de pesadelo" de um casal cindido pelo surgimento de um triângulo amoroso cujo vértice era uma jovem também disputada por um outro homem.

A novo estava na angústia e nas dúvidas mundanas acima de qualquer dor coletiva e, como em Salgueiro, a ideia da morte surge como a única transcendência humana possível, uma marca de seu catolicismo, sempre em

Lucio Cardoso estranhando volta e indaga:

- Que é?

- Não é com você, é com o Octávio ... E fez uma insinuação...

Como era natural, o Sr. Lucio Cardoso responde altivamente. E há luta. Pancadaria! Apartaram... E quando apartaram o Sr. Lins do Rego - cabelo assanhado - foi lá para o fundo resmungando, resmungando, apanhado..." A matéria foi publicada no jornal $O$ povo com o titulo "Esbofeteado o Sr. José Lins do Rego". O recorte se encontra sem data no AMLB da Fundação Casa de Rui Barbosa. Segundo Bueno, a revista Acadêmica teria saído em defesa de Lúcio Cardoso negando o matéria publicada em $O$ Povo, que segundo a publicação seria um complô integralista para ganhar a adesão do escritor. Ainda no livro de Bueno, Graciliano Ramos teria negado totalmente o incidente. Ver BUENO, L., op.cit., p. 418-419. 
contradição com seu horror ao tradicionalismo e reacionarismo mineiro. A luz no subsolo veio a ser um tema espinhoso para o autor: "Tínhamos tocado num ponto capital”, escreve Brito Broca em sua entrevista.

A luz no subsolo foi um livro incompreendido e muito atacado, há dois anos quando apareceu em edição da José Olympio. Era um romance hermético, difícil, em que nossos críticos rotineiros preferiram ver uma mistificação. O que pretendia o escritor com aqueles personagens absurdos, agindo numa atmosfera asfixiante de mistério? Ninguém admitia a novidade, a originalidade? Qual seria o pensamento que norteava as criações de Lúcio Cardoso. (Broca, op. cit.)

A dúvida de Brito Broca e sua instigação levaria a um retorno da celeuma Norte-Sul, já bem amenizada em 1938 por motivos diversos e, dentre eles, pelo esvaziamento do projeto do romance social. Naquela mesma entrevista Lúcio tenta resolver e esclarecer sua posição diante de seus contemporâneos e comenta seus pontos de vista acerca do romance social.

A minha concepção de romance vai de encontro ao da maioria dos romancistas modernos, que preconizam uma arte da observação pura, a fotografia da realidade. Querem apanhar essa coisa que vemos aí e nada exprime, porque a verdade está no subsolo. Não os reconheço como romancistas, mas talvez como bons repórteres. (Cardoso apud Broca, op. cit.)

É quando afirma: "Jorge Amado é a maior indignidade do romance brasileiro". Numa guerra aberta com os autores do romance realista principalmente Jorge Amado ${ }^{26}$ e José Lins do Rego - e carregado de certezas sobre a impossibilidade de realização de uma arte literária decalcada pura e simplesmente da realidade, Lúcio desenvolve um processo de negação de suas obras anteriores inspiradas pelo realismo dos anos 1930. Três anos antes, em 1935, em carta a Vinicius de Moraes, é claro sobre o seu posicionamento acerca dos primeiros livros. Renegar parece ser o único caminho: "Reneguei a Maleita e o Salgueiro. Não penso agora senão no 'Demônio",27.

\footnotetext{
${ }^{26}$ Jorge Amado curiosamente, nasceu, como Lúcio, em agosto de 1912.

${ }^{27}$ MORAES, V. de, Cp. 116, de maio de 1935, AMLB, Fundação Casa de Rui Barbosa. A correspondência com Vinicius de Moraes, que só foi liberada ao público em 2011, revela o grau de animosidade, não aberta publicamente até essa entrevista, entre os grupos. Numa resposta a Lúcio, Vinicius escreve: "Evidentemente é preciso fazer qualquer coisa contra essa lava de titica nortista que emburreceu todo mundo de repente. Não se salva mais nada. A não ser o Armando e o
} 
Preocupado com a repercussão da desastrada polêmica, escreve para a redação da revista Dom Casmurro e acusa o crítico de interpretar equivocadamente suas ideias. Há então uma troca intensa de cartas entre ele e Brito Broca, mas o crítico não arreda pé. "Precisava lhe esclarecer um detalhe: a publicação da entrevista na revista Dom Casmurro não teve propósito determinado de dar maior repercussão a conceitos que você já havia considerado 'mal entendidos"', escreve o crítico, que menciona conversa com Álvaro Moreira sobre a decisão de publicar suas declarações sobre Jorge Amado e a literatura do Norte.

Não houve em mim o objetivo de insistir num escândalo literário, na indiferença do ressentimento que pudesse acusar um amigo. Isso já estava para lhe falar há dias quando ontem a acrimônia de sua nota ao Dom Casmurro me fez supor que você se tivesse magoado. [...] Quero ainda mais frisar que ao escrever a entrevista não me passou, nem de longe, a ideia de que ela viesse a suscitar um caso. Você me havia dado plena liberdade (recordo-me até das palavras suas nesse sentido e eu supunha estar sendo demasiado fiel à realidade da nossa palestra). [...] já estou bastante desiludido e experimentado para não sentir a volúpia e os ardores de encrencas literárias, principalmente num momento em que há coisas tão grandes pesando sobre minha vida. Sinceramente, o Brito. ${ }^{28}$

Lúcio teve que conviver com seu ressentimento estampado nas páginas de uma das mais importantes publicações culturais. E, por fim, como ele temia, seu posicionamento sincero sobre a "catastrófica celeuma norte-sul" reacendeu a polêmica do início dos anos 1930 já esquecida naquele período de Segunda Guerra, de Estado Novo e do esvaziamento paulatino do romance regional.

Do erro cometido - deixar-se navegar pelas águas do realismo dos anos 30 à busca do "demônio" foi um passo largo e único na sua história literária. A partir da decisão anunciada a Vinicius de Moraes, com quem trocou inúmeras impressões sobre a situação da literatura naqueles anos, segue em busca de uma literatura fantástica, trágica, que atinge o ápice nas novelas Inácio e $O$ enfeitiçado, de meados da década de 40, em na continuação, a novela Baltazar, publicada em

Graciliano (apenas São Bernardo...), o próprio Zé Américo arrebenta com A Bagaceira com essas suas patadas de cretino-louco. Essa outra gente de Jorge Amados, Clovis Amorins, José Lins do Regos, para a puta que os pariu! São uns burros, não sabem mais o que fazem. É ridículo, é engraçado, como se debatem dentro das mesmas coisas, dentro dessa pocinha de mijo que eles chamam de romance". (Os grifos são meus.) Esta carta, escrita em papel pautado e sem data, certamente foi escrita em 1935 e se encontra do arquivo de Lúcio Cardoso, LC 155 cp, Fundação Casa de Rui Barbosa.

${ }^{28}$ BROCA, B., LC, cp 36, AMLB, Fundação Casa de Rui Barbosa. 
capítulos no "Letras \& Artes” durante os anos 1940. “A imaginação é tudo. É dela que parto para atingir a realidade", disse a Brito Broca na fatídica entrevista de 1938.

A passagem dos anos 1930 para os anos 1940 trouxe uma inquietante transformação na cultura brasileira, muito influenciada por todos os movimentos externos e políticos da sociedade. A Revolução de 30 foi seguida pelo golpe do Estado Novo (1937-1945), e o mundo, por sua vez, tremia com a Segunda Guerra mundial, a perseguição a judeus e o aniquilamento de uma série de liberdades individuais. O Brasil acolhia artistas de toda a parte da Europa e, o romance social de 30, que primava pela heroicização do coletivo, cede aos poucos lugar ao indivíduo, e às preocupações inerentes a esse homem dizimado diante de toda a fúria que o mundo oferecia. Tanto que escritores identificados com o social, como Rachel de Queiroz, Graciliano Ramos e Dyonélio Machado se entregam a dramas ambientados na dúvida e na individualização do homem em Caminho de pedras (1937), Angústia (1936) e Os ratos (1935) (ver Bueno, op. cit., p.439).

Com a mitigação do romance social e o desaparecimento do herói proletário, bem como das grandes revoluções empreendidas por esses homens, surge na literatura um novo personagem, um anti-herói, um individuo fracassado diante da sociedade e dizimado pelas doenças e pela fraqueza moral.

Em abril de 1940 Mário de Andrade, em sua coluna "Vida Literária" do jornal carioca Diário de Notícias escreve o artigo "O traço característico":

É estranho que está se fixando no romance nacional a figura do fracassado. Bem, entenda-se: para que haja drama, pra que haja romance, há sempre que estudar qualquer fracasso, um amor, uma terra, uma luta social, um ser que faliu. Mas o que está sistematizado, em nossa literatura, como talvez péssimo sintoma psicológico nacional não é isso. [...] Em nossa novelística (e é possível buscar bastante longe as raízes disto, num Dom Casmurro, por exemplo, ou sistematicamente num Lima Barreto) o que está se fixando, não é o fracasso proveniente de forças em luta, mas a descrição do ser incapacitado para viver, o indivíduo desfibrado, incompetente, que não opõe força pessoal nenhuma, nenhum elemento de caráter contra as forças da vida, mas antes se entrega sem que nem porque à sua própria insolução. Será esta, por acaso, a profecia de uma nacionalidade desarmada para viver?" (Andrade, 1993, p. 181).

Para Bueno, a hipótese de Mário de Andrade é a de que o fracasso domina o romance e define sua visão da nacionalidade. "Contrapondo-a à sua própria visão de nacionalidade, é natural que vá considerá-la derrotista, vetor da desistência, 
'sintoma de que o homem brasileiro está às portas de desistir de si mesmo'. E ele acerta em cheio ao apontar o fracassado como a figura hegemônica no romance de 30", escreve o ensaísta (Bueno, op. cit., p.76). Mas supomos que esse fracassado, além de representar a ideia de um herói incompleto, um herói em que as lutas sociais redundaram num vazio social, é o reflexo de como as ideias não resultaram em melhora de vida íntima ou social. Por outro lado, o fracassado é também um personagem que une as visões de mundo de todos os romances e de todas as linhas estéticas e éticas que guiavam a literatura brasileira e deságua em 40 numa procura pelo entendimento social a partir do individuo. A figura do fracassado vem, de alguma maneira, colocar sob um mesmo parâmetro tanto o romance ideológico, como o intimista. O sentimento de perda, de ausência de projeto, de futuro e de utopia podem, segundo Bueno, ser encontrados tanto em São Bernardo, de Graciliano Ramos (1934), como em A luz no subsolo, de Lúcio Cardoso (1936). De qualquer maneira, esse era um elo comum, reflexo de toda uma experiência social negativa num país que, mesmo após todas as incipientes revoluções, não atendia às expectativas formuladas pelas gerações anteriores.

Embora a figura do "fracassado" constitua um ponto comum entre os projetos literários diversos da época, a disputa travada naqueles anos entre o social e o íntimo, a direita e a esquerda, carolas e não carolas, comunistas e liberais, prossegue em vários setores da intelectualidade, sobretudo nas disputas ideológicas travadas nos cadernos literários. A Segunda Guerra “implodiu consciências" e para um grupo, ainda majoritário, do romance social, não havia espaço para o íntimo num mundo em chamas. E para os intimistas, literatura não podia ser feita a partir do "caderninho de reportagem". Lúcio Cardoso e outros, como Cornélio Penna, acreditavam que o espaço literário não poderia ser asfixiado pela narrativa do presente e tampouco transformado numa reportagem de época. A obra literária, de arte, segundo eles era atemporal. Como lembra Antonio Candido:

Depois de 1940, ou pouco antes, vamos percebendo a constituição de um período novo. Nos dois decênios de 1920 e 1930, assistimos ao admirável esforço de construir uma literatura universalmente válida (pela sua participação nos problemas gerais do momento pela nossa crescente integração nestes problemas) por meio de uma intransigente fidelidade ao local. A partir de 1940, mais ou menos, assistiremos, ao lado disso, a um certo repúdio ao local, reputado apenas pitoresco e extraliterário; e um novo anseio generalizador, procurando fazer da expressão 
literária um problema de inteligência formal e de pesquisa interior. [...] Os novos manifestaram pouco interesse pela literatura ideológica de esquerda e de direita. (Candido, 2008, p. 133)

Já na década de 1940, o próprio Lúcio Cardoso tenta estruturar o momento literário em que vivia em três correntes: a mística-teológica, a comunista (de finalidade místico-coletiva) e a terceira, na qual certamente ele se encontrava, a individualista (de finalidade místico-egocentrista). Neste artigo, "Confissões de um homem fora do tempo", de meados de 40, faz, além da sua classificação das formas literárias vigentes, afirmações polêmicas sobre a relação do escritor com a Segunda Guerra, transpondo para o cenário de guerra aquela que se tornou sua questão desde o momento em que renegou o realismo de seus primeiros livros: até em que medida os problemas sociais influenciam a literatura e a criação. Sua visão sobre a recepção da Segunda Guerra no país, pelos seus contemporâneos, torna-se, entretanto, uma provocação polêmica e, aparentemente, insensível. "Acho a guerra monótona, bem sem interesse como experiência e já bastante adivinhada nas suas conseqüências profundas. E depois, a morte em certos casos é tão banal! Já não há esse horror que os telegramas teimam em nos apresentar. [...] Ao meu ver é quase uma morte burocratizada. ${ }^{29}$

A banalização da morte por meio do noticiário e de fotografias de guerra, aqui sublinhada, remonta às mais recentes teorias da espetacularização, seja do mal, seja da mídia. Como veremos adiante, a relação do autor com a morte e com a imaginação da morte e do que possa estar além da vida é mais do que religiosa, estética e literária. A morte e a luta entre o bem e o mal foram seus principais personagens em mais de uma centena de contos e crônicas que analisaremos nos dois principais capítulos. Sua banalização sugere uma perda dos sentimentos éticos e estéticos por ele corporificado. "A morte é, antes de tudo, uma libertação do corpo de sua vida sob a ameaça da doença e do desaparecimento - uma espécie de saúde, definitiva, que nos ilumina sempre jovens como uma primavera do sangue", escreveu em seu Diário completo (Cardoso, 1970, p. 242).

Lúcio Cardoso foi escritor e católico - muito diferente de ser escritorcatólico como muitos o credenciaram - e ao longo de sua vida e obra a relação paradoxal entre o bem e o mal proposta pela religião, bem como a morte

${ }^{29}$ CARDOSO, L., "Confissões de um homem fora do tempo", circa 1940, Arquivo Lucio Cardoso, AMLB, Fundação Casa de Rui Barbosa. 
redentora, balizaram seus primeiros conflitos éticos e estéticos. Mas com o tempo, a figura de um Deus redentor e de uma morte que pudesse superar a vida já não frequenta com tanta certeza as páginas de seus contos e novelas. Tornou-se, como muitos autores de formação católica (ver Andrade, M. Aspectos da literatura brasileira, 1974) ${ }^{30}$ mais interessado no eu profundo e nas "camadas mais fundas da tristeza humana", ${ }^{31}$ como escreveu em $O$ Enfeitiçado, do que na entrega ao destino puramente religioso. Entre o seu Deus e a vida eterna, existiam homens de carne e osso, seres frustrados e aniquilados pela vida, sobrevivendo dramaticamente no subsolo das relações afetivas e pessoais, demonstrando muitas vezes o lado oculto e profundo dos indivíduos cindidos pela moral social e religiosa.

\begin{abstract}
"Que era a vida, que era morte?", pergunta em O enfeitiçado, para em seguida responder: "Criação de um Deus impotente para arrastar suas criaturas até a luz plena, ali jaziam os destroços de sua visão, consciências vivas e visionárias, cerceadas de todos os lados pela doença, pela fome, pelo tédio, pelo vício e pela morte. Não, nenhum Deus ousaria ter levantado semelhante caos. O homem nasce do chão [...]. Não há destino, nem missão a cumprir. Duramos como os objetos mortos duram. (Cardoso, 1954, p. 227).
\end{abstract}

O catolicismo, como Minas Gerais, sempre foi um espinho, ou como escreveu em carta ao crítico gaúcho Paulo Hecker Filho: "Inventei um catolicismo a minha moda, frouxo e sem consciência" (ver Carelli, op. cit., p. 63). Em diversas passagens de seu diário, e mesmo de seus contos fantásticos, a morte ora foi compreendida como detentora de um poder e caráter libertador, ora como "um acontecimento sem filosofia" (Cardoso, 1970, p. 257). Para defender a sua opção não realista escreveu alguns artigos. Alguns deles confusos e herméticos, outros esclarecedores. Mas igualmente hermético para seus principais receptores: os defensores políticos de um romance social. "Há muitos anos que ouço os nossos arrebatados jovens me chamarem de reacionário. [...] É verdade que não creio no romance sociológico, mas também não creio em Virginia Woolf'. 32

\footnotetext{
${ }^{30}$ Especialmente "A volta do Condor (1940-41)", artigo sobre Augusto Frederico Schmidt, p. 141172.

${ }^{31}$ Id., p. 169.

${ }^{32}$ CARDOSO, L.. "Confissões de um homem fora do tempo", Arquivo Lúcio Cardoso, AMLB, Fundação Casa de Rui Barbosa, s/d.
} 
Em resposta às suas teorias sobre a banalização da morte a partir dos relatos de guerra, foi publicado o artigo "O sapateiro e a guerra" assinada por Clovis Ramalhete. O jornalista não poupou críticas pessoais e estéticas ao escritor, acusando-o, dentre outras atitudes, do fato de trocar o sol dos primeiros romances, pela sombra e o ambiente soturno do indivíduo em sua obra recente. Era imperdoável para a crítica secundária, de jovens estudantes de direito e beletristas, uma mudança de posicionamento.

Começou [sua literatura] tentando por problemas sociais descrevendo dramas de gente de carne, osso e andrajos. Estava, até então, de olho na partitura da moda. Mas logo optou por um caminho de solidão. Como mais propício à celebridade, e pôs fermento de pão-de-ló no subjetivismo, para aplicar-se a uma ficção de fofas introspecções. [...].

Adotou o "tom noturno" na ficção deste país de sol, pedras coruscando, cactus, seca e seca e crimes passionais, confundindo erro com originalidade. E descansou serenamente sobre a certeza de sua obra. Não sofre de insônias, nem jamais duvida de si próprio esse inabalável. [...] Em certas páginas de sua estética de subterrâneo, aborda lances vigorosos, de nervos crispados, mas tudo soa falso e frágil. Lembra dó de peito de menino de coro. Toda a aparência de fracasso vem da "maneira" literária, da "fórmula" adotada para sua literatura de quarto de doente, sem janelas abertas. ${ }^{33}$

No artigo "Os romances do ódio", de 1944, Lúcio promove uma blague sobre um concurso literário em que um dos critérios era realizar, em tempos de guerra, um romance sem encontro amoroso ou um crime. E, mais uma vez o escritor polemiza com o apelidado "romance de anotação" e com as delicadas questões frente à guerra.

A guerra existe, mas também não é possível erigi-la como objeto sagrado. É o que faz grande número de escritores - artistas sem alma, escritores medíocres inundando o mundo com uma classe de literatura mais efêmera do que o vento que passa.

Como justificativa alegam que o romance deve refletir sua época, sem tempo, condições e não sei que mais. Evidentemente é desprezar o verdadeiro escritor. Não que ele não deva refletir seu tempo, mas o fato que se "existe" nele um grande artista, querem ou não políticos e os acusadores, refletirá o tempo na sua obra, e isto não porque saia de caderninho em punho tomando nota o que se passa, mas porque é próprio dos verdadeiros artistas modular a fisionomia da época em que vive. (Cardoso, 1944)

\footnotetext{
${ }^{33}$ RAMALHETE, C.. "O sapateiro e a guerra”, Diário Associados, Arquivo Lúcio Cardoso, AMLB, Fundação Casa de Rui Barbosa, s/d.
} 
Uma guerra nada silenciosa foi travada no centro da literatura brasileira eriçada por ideologia estanques fez com que grupos lutassem por uma função política (ou não) da literatura. Ao longo da década de 1940, e com o fim da guerra, o debate mostrou-se circunstancial e decadente. Novos autores, tais como Clarice Lispector, Fernando Sabino e mesmo os autores relacionados no passado ao romance regional, como mostramos acima, já apresentavam uma nova relação do homem com o espaço literário e esse lugar passava eminentemente pelo subjetivo, pelo retorno do indivíduo no centro da trama. Lúcio e os regionalistas, ou os escritores do Norte, jamais voltaram a ter uma relação amistosa. Em abril de 1954, uma década após as últimas contendas, escreve em seu Diário completo:

Lembro-me de alguns anos atrás e um nome se impõe na minha memória, o de Rachel de Queiróz. Lembro-me como naquela época fui grosseiro, voluntarioso e tolo; como desconhecendo completamente os valores efêmeros deste mundo, esmaguei uma amizade com os fumos do meu orgulho e da minha leviandade. (Cardoso, 1970, p. 186)

Em 1957, no dia da morte de José Lins do Rego, Lúcio Cardoso manifestase saudosista em seu Diário: "Lembrei-me do tempo que andávamos juntos [...]. Podemos não sentir a idade, mas ela se faz presente através dos mortos que vai semeando em torno de nós" (id., p. 220). Já com relação a Jorge Amado, anos depois, passada todas as mágoas dos anos 1930, Lúcio numa entrevista à revista Chuvisco, em fevereiro de 1961, cita dentre seus escritores nacionais prediletos, Jorge Amado, ao lado de Octávio de Faria e Guimarães Rosa. Jorge Amado, por sua vez, em seu discurso de posse na Academia Brasileira de Letras, no mesmo 1961, faz a seguinte referência a Lúcio ao falar do Romance de 30: “A dilacerante novelística de Lúcio Cardoso, o espantoso menino dos tempos de Maleita, o romance de hoje o mesmo de Crônica da Casa Assassinada. ${ }^{34}$

\footnotetext{
${ }^{34}$ Ver em http://www.academia.org.br/abl/cgi/cgilua.exe/sys/start.htm?infoid=723\&sid=244
} 


\section{4 \\ O diabo e a busca pelo conto}

Após o conturbado final da década de 30, com a frustração da crítica, dois livros renegados e uma intensa campanha defensiva, Lúcio Cardoso inicia a década de 1940 com as novelas Céu escuro e $O$ desconhecido. Em 1943 publica o romance Dias perdidos, considerado autobiográfico, e talvez o único romance do período que não tenha o clima sufocante de dias "opressos", para usarmos uma das expressões mais constantes de seu vocabulário. Mas aqui, como em quase toda sua obra, as vidas são entregues à mesma doença do fracasso. A linguagem deste romance difere, entretanto, daquela usada pelo autor nos livros posteriores e anteriores. Limpa, sem os exageros quase barrocos caracterizados pelo embate de sombras e luminosidades das novelas da década anterior e da primeira metade dos anos 1940, Dias perdidos tem momentos de profunda beleza pictórica, uma das duas características sempre muito presente em toda a obra de Lúcio Cardoso: as imagens e os enredos roteirizados, herança de sua paixão pelas artes e pelo cinema. $^{35}$

É em 1944, entretanto, que lança Inácio, sua primeira obra de cunho fantástico - por nós considerado - e que inaugura uma fase denominada pelo estudioso Mário Carelli de "satânica”. Na sequência de Inácio, entre 1945 e 1946, escreve $O$ enfeitiçado, cuja publicação só ocorre quase uma década depois, em 1954, mas trechos do livro são publicados no "Letras \& Artes", em 1946, com o nome de "Reaparição de Inácio", e no qual Lúcio Cardoso explicita seu desejo de ter as novelas ditas "satânicas" continuadas: "A história de Inácio, de Lúcio Cardoso prossegue em duas novelas subsequentes que se denominarão Reaparição e Céu Escuro. É de Reaparição o capítulo que publicamos nesta página" (Cardoso, 1946, p. 5), adverte o olho da página emoldurada por uma bela gravura de Goeldi, que ilustra a maior parte das contribuições de Lúcio para o "Letras \& Artes", suplemento literário do jornal A Manhã.

Há várias ponderações a serem feitas sobre esse anúncio, e a primeira delas é que Céu escuro já havia sido publicado numa separata da revista Vamos ler, em

\footnotetext{
${ }^{35}$ Lúcio Cardoso dirigiu dois filmes, Almas adversas e Mulher de longe, em 1948 e 1949, respectivamente, além de ter escrito uma dezena de roteiros. Após o AVC, em 1962, dedica-se à pintura.
} 
1940. E o título "Reaparição de Inácio" nunca foi utilizado pelo autor para a obra subsequente a Inácio, que foi $O$ enfeitiçado. O importante dessa pequena explicação do "L\&A" é nos mostrar a clara intenção do autor no sentido de dar à sua obra um projeto globalizante, fechado sempre em trilogias. A primeira delas, ainda na década de 1930, se chamaria "Luta contra a morte", da qual fariam parte A luz no subsolo, Apocalipse e Adolescência, esses dois últimos escritos, porém jamais finalizados. ${ }^{36}$ Depois surge o projeto de "O mundo sem Deus", no qual as novelas Inácio, $\mathrm{O}$ enfeitiçado e Baltazar, publicados primeiro na imprensa da década de 40 e depois postumamente, enfeixariam o conjunto em torno da principal ideia de um mundo povoado pelo diabo no fracasso de um Deus contemporizador e do homem aniquilado pelo "mundo de sono", pelo ódio, pelo tédio, pela cobiça, pela carne, pela insatisfação, orgulho, fantasia e vaidade (Cardoso, $O$ enfeitiçado, p. 178). Enfim, pelos mais humanos, extremamente humanos, aspectos da vida.

Todos os projetos de suas trilogias jamais foram levados ao fim. Romances que pudessem ser lidos como o roman-fleuve francês foi um cacoete de época, e lançou alguns escritores ao desafio de criar uma longa e definitiva visão de mundo por meio de uma história-espelho do contemporâneo, como em Balzac e Proust, e influenciados pela obra de Dostoievski. Dentre os escritores, Octávio de Faria levou às últimas consequências essa ideia de um mundo à parte, criando os 15 volumes de sua laudatória Tragédia burguesa, que se inicia em 1937, com Mundos mortos, e termina em 1970, com O pássaro oculto.

Ainda na década de 1940, Lúcio Cardoso publica duas outras novelas, A professora Hilda e Anfiteatro, ambas em 1946, mas deste ano em diante suas publicações tornam-se rarefeitas e só ressurgem em 1954, quando finalmente publica $O$ enfeitiçado, escrito em meados da década de 1940. O escritor cai num profundo ostracismo editorial, e nenhuma de suas produções literárias, muito

\footnotetext{
${ }^{36}$ Ver CARDOSO, L., "Inventário do Arquivo L. C.”, AMLB, Fundação Casa de Rui Barbosa. O mais interessante dessa arqueologia literária é anotar e perceber as falhas da história, os momentos de dúvida e incompletos de um autor. Lúcio em seu Diário sempre reclamava de si mesmo como uma pessoa que não se levava a sério. Podemos confirmar sua autocrítica ao longo de seu acervo e no cotejo entre os documentos manuscritos e o que foi publicado em vida na imprensa. Nesse caso específico, encontramos nos arquivos parte do romance Apocalipse, datado de 1951, enquanto sabemos que o mesmo já vinha sendo escrito em meados de 1940, como fica evidente a partir da menção no "L\&A" de 1946. As lutas entre o desejo e as possibilidades ficam claras nesses projetos que jamais foram finalizados, deixando hoje um rastro daquele confuso presente.
} 
menos o roman-fleuve, são levadas a cabo. Na verdade, após esse longo silêncio, somente em 1959 surge um livro realmente novo, quando a Crônica da casa assassinada é publicada. Como ele próprio explica ao seu editor, Daniel Pereira, da José Olympio, em carta de maio de 1954, a Crônica não faz parte do universo do mundo demoníaco de Inácio e $\mathrm{O}$ enfeitiçado. Na Crônica, Lúcio retoma o drama familiar, das inter-relações e dos jogos de poder, mas numa narrativa verossímil, dentro da perspectiva cardosiana e não de um romance social, e em nada fantasiosa como dos escritos de 40.

\begin{abstract}
Queria conversar com você, e especialmente sobre a Crônica que finalmente tenho quase terminada na sua terceira versão. No sei se você se lembra de uma coisa que anunciei ha muitos anos, o Apocalipse, logo depois que publiquei A luz no subsolo. Pois bem, com o correr do tempo mudou-se ele para um roman-fleuve, em vários volumes, e é um trabalho que considero a minha melhor coisa, a mais bem realizada, Fiz questão de assinalar no fim de $O$ enfeitiçado, que é de 1947, e que a Crônica é de agora. Queria sua opinião sobre o interesse de José Olympio - que tenho visto de vez em quando, na rua - sobre sua publicação, para o ano que vem. Poderia entregá-lo, por exemplo, em Janeiro. Só ha uma complicação: há dois outros, imediatos, que se seguem a ele e que também se acham prontos. Portanto, queria saber também sua opinião, o mais precisa que for possível sobre este ponto: haveria possibilidade de serem editadas as três obras (no caso a Crônica da casa assassinada, $O$ viajante e Réquiem) ou José Olympio publicaria apenas uma? Que acha você? Para mim, e como reaparição de verdade, a publicação dos três seria formidável. Uma grande oportunidade, que me faria recuperar todos esses anos de inatividade. ${ }^{37}$
\end{abstract}

Essa correspondência revela o momento pelo qual passava o escritor e nos mostra sua intenção de finalizar esboços de livros como Viajante e Réquiem, que jamais foram finalizados. O citado Apocalipse transformou-se, em parte, no conto "A escada". E aqui começamos um capítulo da história de Lúcio Cardoso ainda não contada: a sua enorme produção de contos entre o período de meados de 1940 a 1959.

O que nos salta aos olhos é que nessa primeira produção, até 1948, encontramos contos que beiram o fantástico. Histórias em que a evasão e a morte estão constantemente presentes. Quase dez anos depois, o escritor apelidou a primeira leva de Contos da Ilha, e a posterior, de 1948 a 1957, de Contos de Continente (Cardoso, 1970, p. 232). A imensa produção de contos para uma

\footnotetext{
${ }^{37}$ CARDOSO, L., LC 174 cp, correspondência com Daniel Pereira, Arquivo Lúcio Cardoso, AMLB, Fundação Casa de Rui Barbosa.
} 
coluna de jornal, realizados a partir de um tema único, o crime, surge em 1952. A cidade do Rio de Janeiro é cenário dessas mortes e de todos os tipos urbanos, delinquentes, e marginais que finalizam nossa análise. 


\section{2 Lúcio Cardoso e o conto no Brasil (1930 a 1950)}

\section{1 Lúcio e o conto}

Lúcio Cardoso escreveu ao longo de 28 anos de produção literária cerca de 400 contos, dos quais mais da metade sob encomenda do jornal A Noite, ${ }^{38}$ no qual manteve entre 1952 e 1957 três colunas ${ }^{39}$ sobre o crime e a vida trágico-urbana de homens e mulheres na cidade do Rio de Janeiro. Muitas dúvidas e poucas respostas cercam a produção de contos do autor. Por que essa volumosa produção ficou por mais de setenta anos inédita em livro $?^{40} \mathrm{O}$ que levou o romancista e poeta a escrever tantos textos curtos? E o que escreveu Lúcio Cardoso? Quais foram suas temáticas e personagens, onde ele inovou?

Até a publicação de Contos da ilha e do continente, em dezembro de 2012 fruto de minha pesquisa, levantamento e organização -, não havia qualquer registro da produção no gênero do escritor, com isso sua obra inexistiu em todas as compilações do conto brasileiro. Intimista, realista, fantástica, seguidor irrestrita dos preceitos do "efeito único", técnica narrativa preconizada por Edgar Allan Poe no século XIX, o conto de Lúcio Cardoso é o resumo de toda a sua invenção ficcional, onde ele pode experimentar os mais variados estilos e

\footnotetext{
${ }^{38}$ Jornal carioca diário e vespertino, fundado em 18 de junho de 1911 e extinto em 27 de dezembro de 1957. Durante o período do Estado Novo (1937-1945), foi encampado pelo governo em 8 de março de 1940, passando a fazer parte do patrimônio da União. O jornal viveria sua última fase, de 1940 a 1957, em crise permanente. Sendo parte das Empresas Incorporadas do Patrimônio Nacional, após a encampação a administração de A Noite, ficou a cargo do superintendente do órgão, o coronel Luiz Carlos da Costa Neto, e a direção propriamente do jornal foi ocupada pelo jornalista André Carrazzoni. Após o suicídio de Vargas, em 1954, as novas e sucessivas substituições nos quadros administrativos representaram um golpe final para as Empresas Incorporadas, em particular para A Noite. Segundo Carvalho Neto, em entrevista à equipe do CPDOC/DHBB, a inviabilidade do jornal deveu-se também ao fato de ser ele um órgão do governo: "O povo não admite, com toda razão, que o governo seja dono de jornal para ele ler. E deixou de ler A Noite... Jornal do governo é Diário Oficial". Cerca de dois anos após a posse de Juscelino Kubitschek, em janeiro de 1956, o jornal saiu de circulação. Ver Dicionário HistóricoBiográfico Brasileiro Pós-1930 (2001, volume IV, p. 4107).

${ }^{39}$ As colunas "O crime do dia", "Novelinha do dia-a-dia" e "Diário não-íntimo".

${ }^{40}$ Com exceção do conto "Acontecimento da noite", parte do livro $O$ conto mineiro, de 1959, organizado por Edgard Cavalheiro para a editora Civilização Brasileira, e de "Carnaval de antigamente", que consta da Antologia de Carnaval, edições O Cruzeiro, 1945.
} 
temáticas. Para Alfredo Bosi, em $O$ conto brasileiro contemporâneo, no gênero literário a "invenção temática" tem um lugar fundamental.

\begin{abstract}
Quanto à invenção temática, o conto tem exercido ainda e sempre o papel de lugar privilegiado em que se dizem situações exemplares vividas pelo homem contemporâneo. Repito a palavra-chave: situações. Se o romance é um trançado de eventos, o conto tende a cumprir-se na visada intensa de uma situação, real ou imaginária, para a qual convergem signos de pessoas e de ações e um discurso que os amarra. [...] A invenção do contista se faz pelo achamento (invenire = achar, inventar) de uma situação que atraia, mediante um ou mais pontos de vista, espaço e tempo, personagens e trama. Daí não ser tão aleatória ou inocente, como às vezes se supõe, a escolha que o contista faz do seu universo. (Bosi, 1974, p. 8)
\end{abstract}

E quais foram as escolhas do escritor em seus contos? Houve alguma unidade? Classificamos a produção de contos de Lúcio Cardoso em dois grandes blocos. O primeiro, que começa ainda na década de 1930 e se estende até o final da década de 1950, início de 1960, chamamos de os contos gerais, ou simplesmente, contos. Foi onde ele inovou, colocando em prática novas temáticas e concepção de tempo e espaço surpreendentes para o período. O segundo bloco tem início na década de 1950, e o chamamos de contos de crime. A temática, aqui, é a vida, o crime e os personagens populares das colunas de A Noite.

O primeiro conto de Lúcio Cardoso de que temos notícia foi "Cantiga de roda", publicado em $O$ Malho um ano antes de sua estreia com Maleita (1934). As publicações do autor na década de 1930 foram escassas, e esse primeiro texto atendia ao modelo de literatura engajada socialmente, tendo na denúncia da miséria e no confronto social o ápice da história. Alguns periódicos mantinham as publicações de contos, e um deles era $O$ Malho, que já no início dos anos 1920 trazia a coluna "O conto da semana", ampliada na década seguinte em pelo menos mais dois textos curtos de ficção. Autores secundários ocupavam as páginas dos jornais no período de 1920, ladeando autores internacionais como Rudyard Kipling e Charles Dickens. Mas, ao que consta no artigo "Notas em torno do conto", de Herman Lima (1946), foram naqueles anos que surgiu a primeira antologia de contos brasileiros organizada por Alberto de Oliveira e Jorge Jobim, em 1922, para a Editora Garnier. Esta publicação reuniu contos de José Veríssimo, Viriato Corrêa, Rodrigo Octavio, Aluizio de Azevedo, Gustavo Barroso, Monteiro Lobato, João Ribeiro, Medeiros de Albuquerque, Machado de Assis, Affonso Arinos, Graça Aranha, Thomaz Lopes, Lucio de Mendonça, João 
do Rio, Virgilio Varzea, Alcides Maya, Olavo Bilac, Garcia Redondo. Mas é também do período o primeiro volume de contos de Mário de Andrade, Primeiro andar, publicado em 1926.

Nos anos 1930, poucos autores do romance proletário ou social se aventuraram no conto, preferindo a novela e o romance. Em seu clássico artigo "O narrador", Walter Benjamim opõe o romancista à figura do narrador, apontando o primeiro como um sujeito segregado e isolado do mundo. "Escrever um romance significa, na descrição de uma vida humana, levar o incomensurável a seus últimos limites" (2008, p. 201). Para Benjamin, ao contrário do romancista, que tem a matéria de seu trabalho revelada pela invenção e solidão, o narrador retira da experiência do outro e de sua própria a expressão e o conteúdo de sua escrita, aproximando-se sobremaneira da literatura oral (e da reportagem). Os romancistas de 30, curiosamente, apropriaram-se das técnicas do narrador benjaminiano para desenvolver o romance, relegando o conto e a crônica, mais próximos da experiência e vivência, a um segundo nível. Em parte, podemos creditar essa postura ao fato de a imprensa brasileira no período ser majoritariamente de origem burguesa, isto é, lida, comprada e abastecida pelas classes urbanas e populares da pequena burguesia (ver El Far, 2006; Miceli, 2001). Não havia muito espaço para textos revolucionários, e mesmo o texto literário chegou aos suplementos dos impressos de grande circulação paulatinamente, sendo os mesmos ocupados por textos informativos e de entretenimento.

É na década de 1940 que o conto ressurge para os escritores que dominavam a cena literária. Em 1941, uma pequena nota no Diário de Notícias anunciava que Lúcio Cardoso publicaria ainda naquele ano um volume de contos: "Do Sr. Lúcio Cardoso vamos ter, talvez ainda este ano, um livro de conto também, cujo título ainda não está assentado". ${ }^{41}$

A nota, talvez inflacionada pelo desejo de publicação, não espelha a realidade, pois o grande volume de publicações do autor foi na segunda metade da década de 1940, a partir do surgimento do suplemento "Letras e Artes", em 1946. A dedicação de Lúcio aos contos nunca foi prioridade em sua literatura. Pouco escreveu sobre seus contos no diário, ao contrário das suas menções aos romances, e às produções teatrais e cinematográficas. Escrevia-os para

\footnotetext{
${ }^{41}$ Diário de Notícias, 12.10.1941, Rio de Janeiro, p. 18.
} 
experimentar novos cenários, linguagens, testar personagens e, sobretudo, para sobreviver, pois foi da venda desses textos e de seu trabalho na imprensa que tirou seu sustento por um longo período de sua vida, apesar de seu desgosto com o ambiente e a política dos jornais, conforme confessou diversas vezes em seu diário. Talvez seu desgosto pela imprensa tenha ajudado a deixar essa produção inédita, intocada por quase 70 anos. Até mesmo as novelas, gênero predileto do autor, foram uma espécie de atalho para chegar ao romance, e de preferência ao grande romance, a obra-prima, que atingiu com a publicação de Crônica da casa assassinada, em 1959. "Atormentado durante todo o dia pela ideia de escrever romances. Já não penso em novelas, o que resolvia um pouco a minha preguiça em atacar temas muito extensos." 42

Em outubro de 1957, entretanto, Lúcio Cardoso deu uma pista muito clara sobre seu desejo de reunir seus contos e menciona no diário seus escritos sobre ilhas. Também na mesma passagem comenta sobre sua nova produção de histórias curtas acerca do tema "continente", que vinha escrevendo para $O$ Estado de $S$. Paulo. E foi só. 'Escrevi um conto - 'Colchão Velho' - que muito me satisfez. Preparo um outro: 'Atriz no bar'. Ambos para um jornal em S. Paulo, e que marcarão o início de um novo livro de contos, bem diferente de Contos da ilha. Título? Não sei. Qualquer coisa como Contos do continente."43 O conto "Colchão velho" foi publicado somente em agosto de 1958 em O Estado de S. Paulo e foi incluído em Contos da ilha e do continente. Já "Atriz no bar" nunca foi encontrado, assim como não temos notícia de nenhum livro do autor chamado Contos da ilha.

Poucos autores se debruçaram sobre a história e origem do conto no Brasil. Esses poucos são unânimes em observar o forte vínculo do gênero com o crescimento industrial da imprensa e do número de leitores de jornais. Registram, também, a relutância do crescimento e da fixação da literatura brasileira como leitura ligeira.

A influência do periódico na expansão ou na proliferação do conto não foi imediata e instantânea. Há um processo lento de influências e reações dependentes do próprio desenvolvimento e do aperfeiçoamento da imprensa, assim como da formação de um público especial, numeroso e exigente, escreve Barbosa Lima

\footnotetext{
${ }^{42}$ CARDOSO, L. Diário, op. cit., p. 42.

${ }^{43}$ Idem, p. 232
} 
Sobrinho na apresentação de Os precursores, primeiro volume da série Panorama do conto brasileiro, de 1959 (p.7).

Já em 1934, Walter Benjamim, em suas reflexões sobre a literatura e as novas técnicas, afirmava que os textos informativos e jornalísticos se tornaram leitura indispensável, mas ao inserirem o caráter de urgência estariam servindo um veneno mortífero para o romance e seus leitores. A fome pela urgência seria, segundo ele, uma das responsáveis pela morte do romance e, sobretudo, do leitor de romances. Ainda no mesmo cipoal de ideias sobre o impacto da informação na literatura, opõe a narrativa oral das sociedades tradicionais àquela dos contos.

Com efeito, o homem conseguiu abreviar até a narrativa. Assistimos em nossos dias ao nascimento da short story, que se emancipou da tradição oral e não mais permite essa lenta suposição de camadas finas e translúcidas, que representa a melhor imagem do processo pelo qual a narrativa perfeita vem à luz do dia, como coroamento das várias camadas constituídas pelas narrações sucessivas. (Benjamin, 1985, p. 206)

O texto de Benjamin nos coloca diante das questões técnicas e de sobrevivência da narrativa naqueles anos em que o registro e as histórias decalcadas do cotidiano se sobrepunham à ficção e à fantasia no terreno das narrativas impressas. Além disso, as novas técnicas de impressão agilizavam a disseminação e divulgação das histórias cotidianas nos jornais e consequentemente influenciaram as narrativas (ver Ferreira, 1977; Cardoso, 2009). O conto, vinculado às tradições orais e ao folclore, ao contrário da poesia, sempre teve suas raízes nas camadas populares. Entretanto, entre nós sua veiculação foi tardia e encontra no jornalismo e na reportagem, que surgiam céleres nas décadas de 1920 e 1930, outras formas de narrar o cotidiano e de criar histórias, um concorrente talvez mais forte do que os outros gêneros literários.

“Todavia, mesmo quando as manifestações culturais se confinam à tradição oral, obteve a poesia uma preeminência, que leva historiadores a afirmar que ela constituía a primeira forma literária”, explica Barbosa Lima Sobrinho. Patinho feio entre os gêneros literários, espremido historicamente entre a poesia, o romance e a reportagem, esse fruto da tradição oral, entretanto, sempre esteve relacionado ao mundo do maravilhoso, da invenção, do suprarreal, dividido em cinco grandes temas: o conto popular; o conto infantil; o galante; o conto-fábula, 
incluindo as histórias com animais, que compreenderiam o conto maravilhoso; e o conto civilizador de fundo moral. Um dos gêneros mais antigos de narrar histórias humanas por meio da representação escrita, o conto reside no fundo das almas, no modo mais ancestral e quase atávico, pela repetição e uso, de contar histórias.

Em nossa literatura o conto chegou tardiamente. Há inúmeras discussões sobre qual teria sido o primeiro conto brasileiro. Segundo Barbosa Lima, a publicação pioneira, que divulgou o gênero, foi $O$ chronista, cujo primeiro volume data de maio de 1836, sob a direção de Justiniano da Rocha, brasileiro instruído na França. A publicação começa com alguns contos estrangeiros - como veremos se repetir em toda a sua história, até a década de 1930. O próprio Justiniano teria publicado uma série de contos que se assemelhavam a crônicas, como A caixa e o tinteiro, Mais venha dinheiro, $O$ enforcado, dentre muitos outros (ver Lima Sobrinho, 1959, p. 17). Barbosa Lima constrói a partir da verificação das primeiras publicações de $O$ chronista uma sequência meticulosa de cada edição de contos nos primeiros 50 anos do século XIX, citando título e temática. Entretanto, o grande momento do conto brasileiro, considerada a data de seu nascimento, é a publicação de estreia de Machado de Assis, na Marmota Fluminense, por volta de 1850. "Não haveria exagero em classificar o decênio 1850-1860 como o do apogeu da prosa de ficção, no período romântico. Teríamos, assim, três fases: 1830-1840 - para precursores; 1840-1850 - para afirmação do romantismo e 1850-1860 - para o apogeu da escola (conto), na prosa." (ibid, p. 21)

Machado de Assis (1839-1908), que ao longo de sua vida escreveu cerca de 200 contos (ver Gledson, J. org., 50 contos de Machado de Assis, p. 8), foi precursor do gênero, segundo R. Magalhães Júnior (1959, vol. 7, p. 19). Suas primeiras histórias foram publicadas a partir de 1862, quando já era poeta e jornalista conhecido. Com o "O país das quimeras", que tinha o subtítulo de “conto fantástico", Machado inaugura o conto brasileiro.

Apesar da força dos contistas que surgiram em 30 e, em maior número, em 40, Machado foi e é considerado pela crítica como o maior autor brasileiro de textos curtos, a aplicar a ideia de "efeito único" de Edgar Allan Poe (1809-1849) antes até mesmo de sua popularização entre nós. “A figura máxima em todas as épocas, insuperada mesmo por um João Alphonsus, Ribeiro Couto, ou Graciliano Ramos, é, no entanto, Machado de Assis, primeiro cronologicamente, depois por 
força de sua arte sem-par nas letras nacionais”, afirma Magalhães Júnior (ibid, p. 19).

Em 1873 (apud Lima, 1946, p. 4), no famoso artigo "Instinto da nacionalidade", Machado de Assis menciona o conto e registra que naqueles anos do século XIX o gênero não estava fixado na literatura brasileira, subsistindo nos jornais uma literatura de entretenimento.

No gênero dos contos, à maneira de Henri Murger, ou à de Trueba ou à de Charles Dickens, que tão diversos são entre si, tem havido tentativas mais ou menos felizes, porém raras, cumprindo citar, entre outros, o nome do Sr. Luís Guimarães Júnior, igualmente folhetinista elegante e jovial. É gênero difícil, a despeito da sua aparente facilidade, e creio que essa mesma aparência lhe faz mal, afastando-se dele os escritores, e não lhe dando, penso eu, o público toda a atenção de que ele é muitas vezes credor. (Machado de Assis, 1873, p. 107-108)

A divulgação do conto não foi simples no país. Nos primeiros anos, surgiram os textos de simples entretenimento, sempre impressos próximo às páginas de cinema, teatro e femininas. Entre os anos de 1920 e 1930, já tinha se distanciado da tradição oral, por mais que autores folcloristas recuperassem vez por outras histórias dessa natureza, e isso aconteceu durante a recuperação do conto na década de 1940, como veremos. ${ }^{44}$ No artigo "Notas em torno do conto", Herman Lima recupera, na década de 1940, os queixumes do crítico Araripe Junior, registrados na revista Semana (de Valentim Magalhães e Max Fleuiss), em 1893, sobre a deficiência de publicação de histórias curtas. Araripe Junior, ao lado de Aluizio Azevedo e Lúcio Mendonça, fez parte do júri de avaliação do concurso de "prosa" do suplemento, que, aliás, mantinha uma média de três a quatro concursos anuais, cujos prêmios variavam entre canetas tinteiro (de ouro) ou obras literárias. O conto era referido como "prosa" e, para o nosso crítico, o que se via naquelas publicações eram romances desistidos, páginas dispersas, longe do conceito da short novel moderna realizada majoritariamente pelos escritores ingleses e americanos.

\footnotetext{
${ }^{44}$ Em 1946, o suplemento do jornal A Manhã "Letras e Artes", publicou ao longo do ano contos folclóricos coletados e publicados por Silvio Romero no volume Contos populares do Brasil, de 1885. No mesmo ano, Aurélio Buarque de Holanda organizou uma edição crítica dos Contos gauchescos, de Simões Lopes.
} 
O desempenho da imprensa e da indústria editorial no país foi fundamental para a divulgação do conto "literário", em detrimento do conto de "diversão" e de imitação de autores franceses (como Alexandre Dumas e Anatole France). A criação de concursos literários foi uma das ferramentas aparentemente eficazes e constantes na divulgação do conto no país e na formação de autores, sobretudo. Na década de 1930, quando Lúcio estreia como contista nas páginas das revistas, publicações como Dom Casmurro, O Malho e Acadêmica mantinham concursos de "conto brasileiro" a fim de descobrir novos talentos para a "literatura ligeira no pais", como revela o anúncio do concurso da Para...Todos, publicado em $O$ Malho:

Todos os escritores do Brasil podem concorrer ao Concurso de Contos do Para todos. Para qualquer dos gêneros: sentimental ou romântico, trágico ou policial e humorístico. Com esse concurso, nós, os que nos batemos pelo conto, pela literatura ligeira no pais, nós vamos mostrar que vencemos! $!^{45}$

\section{2 \\ De 1930 em diante}

Em 1937 surge a revista Acadêmica, dirigida pelos jovens Murilo Miranda e Moacir Werneck de Castro, ambos, na época, com 22 anos. A Acadêmica, revista voltada para o debate de ideias, publicava uma média de dois a três contos gerais por edição e entrou na década de 1940 com o mesmo ímpeto. Paulatinamente, o conto ganha novo interesse do público, dos jovens editores e de uma leva surpreendente de escritores. É quando Lúcio Cardoso se firma como contista, mas é também quando surge Guimarães Rosa (Sagarana, cuja primeira versão foi entregue a José Olympio em 1937, e foi publicada somente em 1946). É nesse momento que o conto se profissionaliza e se estabelece nos jornais, como $A$ Manhãa, ${ }^{46}$ que publicava com frequência, sempre na $4^{\mathrm{a}}$ página.

\footnotetext{
${ }^{45}$ O Malho, 11.10.1930, Rio de Janeiro, p. 16.

${ }^{46}$ Sobre A Manhã: "Jornal carioca diário e matutino criado em agosto de 1941 como porta-voz do Estado Novo e sob a direção de Cassiano Ricardo e Menotti del Picchia. Foi extinto em 1953. Após a instalação do Estado Novo, embora mantida sob o controle da censura, a imprensa nunca foi verdadeiramente favorável ao governo. Desejando contar com um órgão divulgador das principais idéias do regime que inaugurara em 1937, Getúlio Vargas encarregou o coronel Luís Carlos da Costa Neto (superintendente das Empresas Incorporadas ao Patrimônio da União) e
} 
O grande divisor de águas para o conto na imprensa, e que de certa maneira impulsionou a produção de Lúcio Cardoso, foi o surgimento do suplemento "Letras e Artes" do jornal A Manhã. A década de 1940 foi generosa na divulgação da literatura e na inserção de intelectuais em altos cargos nos jornais. Com o suplemento "Letras e Artes" o conto se estabelece definitivamente como um gênero literário, que desde o século XIX, com Machado de Assis, passando pelas décadas de 1920 a 1950, foi formando uma narrativa à parte na literatura brasileira, voltada principalmente para a poesia e o romance, como aponta a crítica italiana Luciana Stegagno Pichio.

\begin{abstract}
Ainda que a literatura brasileira seja abundante de romances e também dos ciclos romanescos, a verdadeira medida do narrador brasileiro é, talvez, o conto, que tem uma precisa tradição como gênero literário autônomo na história literária do país: por um lado, ele nutre-se de um filão popular que lhe fornece a matriz simbólica, a intenção moralista ou a malícia do exemplum; e, por outro, de imitação europeia, sobretudo francesa, que encontra seu sopro no folhetim de meia página de jornal. (Stegagno-Pichio, 2004, p. 542)
\end{abstract}

A proximidade com a oralidade e a pouca tradição literária no país fizeram com que os dois registros, o oral e o literário, coexistissem na feitura do conto brasileiro. De certa forma, o gênero funcionou muitas vezes como uma experiência narrativa em que fosse possível, por meio da temática das histórias orais, introduzir, no literário, a trama popular. E isso aconteceu com a maior parte de nossos autores, inclusive com o intimista Lúcio Cardoso. A sua grande produção do gênero se deu justamente nesse período de 1940, quando encontra, inclusive, um novo cenário para suas histórias: o mar. O outro também é

André Carrazzoni (diretor do jornal A Noite, pertencente às Incorporadas) de elaborar uma lista de nomes de possíveis diretores para um jornal abertamente governista.

Em 1937, esse Cassiano Ricardo havia publicado o livro O Brasil no original, em que defendia "a idéia de uma democracia social como terceira solução, sem comunismo nem fascismo" — um tipo de visão que ia ao encontro das expectativas de Vargas. Além disso, o próprio Cassiano Ricardo afirmava que seu pensamento político tinha muitos pontos de contato com o Estado Novo.

Assim, em 24 de maio de 1941, Cassiano Ricardo foi oficialmente convidado a assumir a chefia do novo jornal a ser lançado pelas Empresas Incorporadas ao Patrimônio da União. A despeito de alguns desentendimentos iniciais relativos à formação do corpo de redação, o novo diretor teve liberdade para convidar elementos de sua escolha, entre os quais figuravam Menotti del Picchia, Barros Vidal (secretário), Jorge Lacerda (auxiliar de direção), Cecília Meireles, Leopoldo Aires, Múcio Leão e Ribeiro Couto. Além dos funcionários estáveis, foram também chamados a prestar sua colaboração Afonso Arinos de Melo Franco, José Lins do Rego, Alceu Amoroso Lima, Oliveira Viana, Manuel Bandeira e Vinícius de Morais, entre outros". Ver mais em Dicionário histórico-biográfico brasileiro, op. cit., vol. III (GAL-MEL), p. 3533-3535. 
valorizado nas novas histórias, bem como o desencontro, o fracasso e a tristeza embalam as tramas mais urbanas e menos familiares.

O conto geral de Lúcio é sobre um homem e uma mulher desassistidos de tudo, mas, principalmente, de sorte. Poucas vezes colocou em questão o material, que pairou em suas histórias como uma sombra da experiência humana, esta sim, fundamental para seu registro. Segundo a classificação histórica sobre o gênero, é um conto de fundo moral, embora o autor tenha escrito contos fantásticos e, no início da carreira, regionalistas.

A Manhã e seu suplemento "Letras e Artes" foram fundamentais, ao lado de A Noite, para a divulgação, e talvez a existência, do contista Lúcio Cardoso. Foi nesses dois periódicos que o escritor publicou mais de $90 \%$ de seus contos. Toda a exclusiva fase de contos marítimos foi publicada nas páginas de A Manhã, dada a generosidade com que esse periódico inseriu contos ao longo de seus oito anos de existência.

Um registro importante: em 1946, o "Letras e Artes" lançou o mais ambicioso concurso literário. Ambicioso não pelos prêmios - 300 contos para o texto premiado na semana e mais 500 contos para o texto premiado ao final da enquete -, mas pela movimentação e aderência que causou o certame. O suplemento dirigido pelo jornalista Jorge Lacerda cooptou grande parte dos escritores e intelectuais, à esquerda e à direita, do Sul e do Norte, católicos e de vanguarda. Tinha como uma das mais famosas colunas as duas páginas principais reservadas aos “Arquivos implacáveis”, de João Condé, em que fotos da infância dos escritores, além de bilhetes e ilustrações de próprio punho de famosos autores davam um ar de celebridade à literatura carioca, onde não houve vanguarda e experimentalismo como em São Paulo. Ilustrado pelos melhores artistas da época, como Goeldi, Santa Rosa, Grassmann, Athos Bulcão e muitos outros, o suplemento foi uma grande ferramenta na divulgação do conto. Foi lá, por exemplo, que surgiu a contista Clarice Lispector, já na década de 1950, e que Guimarães Rosa explicou a verdadeira "saga" para a publicação dos contos de Sagarana.

O grande concurso do "Letras e Artes", portanto, não poderia ser um evento deslocado do espaço literário; muito pelo contrário, foi um espaço de grande inclusão e divulgação da literatura, tendo como um de seus ganhadores o paranaense Dalton Trevisan, então com 21 anos. Seu conto "Eucaris, a dos olhos 
doces", foi publicado em 15 de setembro de 1946, e a comissão julgadora tinha entre seus membros Lúcio Cardoso, Marques Rebelo, Manuel Bandeira e Brito Broca.

Se o "Letras e Artes" legitima o discurso literário do conto nos anos 1940, na década seguinte, mais do que em nenhuma outra, o conto brasileiro surge com novos e grandes autores, a começar por Clarice Lispector, que publica pela coleção Os Cadernos de Cultura do MEC, em 1952, seu primeiro livro no gênero, Alguns Contos. Na mesma década é publicado As obras primas do conto brasileiro, organizado em 1950 por Amiro Rolmes Barbosa e Edgar Cavalheiro, para a Livraria Martins. No final do mesmo período, sai a maior coleção de contos que já surgiu na história da literatura brasileira: O panorama do conto brasileiro, publicado em 11 volumes, em 1959, pela Civilização Brasileira. Reuniu contos brasileiros em diversos tópicos: como o regional (conto do Norte, conto mineiro, conto do Rio de Janeiro, conto paulista, do Sul); como o temático (fantástico, trágico, feminino); e o de escolas literárias (conto romântico e precursores do conto no Brasil).

A coleção Panorama do conto brasileiro teve vários organizadores: Barbosa Lima Sobrinho, Raimundo Magalhães Júnior, Edgard Cavalheiro, dentre outros pesquisadores e conhecedores da narrativa brasileira. A publicação desses 11 volumes começa com Os Precursores do conto no Brasil, de Barbosa Lima Sobrinho, em que autores esquecidos como Justiniano da Rocha e Firmino Rodrigues da Silva são recuperados como os verdadeiros precursores do conto. Este volume inclusive não traz Machado de Assis, que surge somente no volume 7, O conto do Rio de Janeiro, de Raimundo Magalhães Júnior.

Lúcio Cardoso, que em vida não teve seus contos reunidos em livro, tem “Acontecimento da noite", publicado em 1950 no Jornal de Letras, incluído no volume $O$ conto de Minas Gerais. Nesse período dedica-se quase que exclusivamente aos contos feitos sob encomenda para o jornal A Noite. De 1952 a 1957 ele produz mais de 300 textos para as duas colunas que assinou durante o período. Mas a sua dedicação não fez com que abandonasse o literário, sendo desse período os contos por ele apelidados de "contos do continente", em que personagens urbanos sofrem no cadafalso de uma vida subterrânea, mais do que fracassada: verdadeiramente aniquilada e sem ilusões. 


\section{3 \\ Nasce um contista}

\section{1 Os contos gerais e os contos de crime}

Alfredo Bosi, em sua introdução de $O$ conto brasileiro contemporâneo, ao definir o conto atribui-lhe uma série de inter-relações, incertezas conceituais e nenhuma ideia fixa sobre um gênero fechado em técnicas e regras específicas. Para ele, o conto é uma ficção de "caráter plástico" e, por isto, desnorteou muitos teóricos que tentaram aplicar-lhe uma forma definitiva "no interior de um quadro fixo de gêneros" (Bosi, 1974, p. 7). A análise do prof. Bosi foi especialmente constatada na obra de Lúcio Cardoso; dificilmente teríamos como fixar todos os seus contos dentro de um gênero único. Uns tendem para contos urbanos, outros são quase crônicas, embora ficcionais e com desfechos de fundo moral.

A partir dessa variedade temática percebemos, entretanto, que a sua obra pode ser dividida em dois grandes blocos, o primeiro, de contos de temática e gênero livres, tateando aqui e acolá com temas burgueses, urbanos em sua maioria, e ousados em alguns casos pela escolha da temática e pelo tratamento dado aos personagens. Esses contos que nos surpreenderam estiveram presentes em todos os períodos de sua literatura, isto é, da década de 1930 até o final da década de 1950, início da de 1960. Chamamos, portanto, de "contos gerais". O nome dado foi uma das tentativas encontradas para diferenciá-los do segundo bloco de textos, apelidado de os "contos de crime". Em seu prefácio, Bosi menciona os contos que se assemelham à crônica e outros que são "quasedocumento folclórico, quase-drama do cotidiano burguês, ora quase-poema do imaginário às soltas, ora enfim, grafia brilhante e preciosa voltada às festas da linguagem" (Bosi, op. cit., p. 7). Podemos dizer que cada texto que lemos e encontramos se encaixa na definição do crítico. Como nos mostra em seu prefácio, existem contos quase crônicas, pelo simples fato de serem muito mais ficcionais e confabularem, ao mesmo tempo, com o cotidiano. Assemelham-se dessa maneira mais ao universo dos contos do que ao das crônicas, apesar de 
versarem sobre o cotidiano da cidade. Os "contos de crime" apresentam uma característica fundamental que os difere dos "contos gerais" e não é apenas sua temática, pois há crime em alguns dos contos gerais, mas pelo fato de terem sido encomendados para uma coluna popular. Ambos, contos gerais ou de crime, trazem em seu cerne o que define um conto como conhecemos: narrativas criativas que têm como condutor-contador um criador-autor que relata acontecimento, nem sempre real, nem sempre falso.

O fundamental em toda essa produção é que temos em cada um desses textos de Lúcio Cardoso uma história, curta, profundamente ligada à vida urbana e à intimidade própria de seus personagens. Nunca um autor brasileiro esteve tão próximo do íntimo de seus personagens, das dúvidas, rancores, memórias e felicidade (mesmo que fugaz), como também do medo coletivo e imemorial que deu longa vida ao gênero fantástico.

A ideia de nacionalidade e todos os outros atributos ideológicos do romance de 1930, e mesmo de um modernismo tardio, inexiste nestes textos e é substituído pelo íntimo que se desdobra no local, na cidade. O homem em seu cotidiano constrói, em cada um desses pequenos textos, uma imagem da cidade do Rio de Janeiro. Neste novo cenário, a partir desse "mosaico" de histórias, situações e intimidades, o local passa a ter prioridade sobre o nacional. "No mundo da 'instabilidade do indivíduo' - na expressão de (Marques) Rebelo - 'tempo de partidos, de homens partidos' (Drummond), o texto não pode ser reflexo do corpo inteiro. Reflete a cidade e os homens em seu aspecto lacunar", escreve Renato Cordeiro Gomes em "O Rio no espelho partido", referindo-se à obra de Marques Rebelo. Mas o mesmo serve para a obra de Lúcio, que, como Rebelo, “perpassa nos contos um traço de nostalgia de um Rio de um tempo mais "simples", (Gomes, 1994, p. 119).

A dramatização do indivíduo, "de cenas da infância", de desencontros amorosos, de frustrações íntimas e universais, das lacunas de cada um, no total, no conjunto, perfila a visão daquele momento, naquela cidade. E é o urbano e o mar que amalgamam essa relação. "O Rio de Janeiro é, assim, lido pela esfera privada da casa, mas que se relaciona com o exterior, a cidade grande sugerida ou anotada como um pano de fundo que interagem nos personagens", escreve Cordeiro Gomes (p. 120). Acrescentaria que, na cidade cardosiana, é o íntimo, é a luta entre e externo e o interno, que revela a cidade. 


\section{2 \\ Uma ilha de melancolia, fracassos e mulheres}

Quando estreou na literatura brasileira, com apenas 24 anos, Lúcio já tinha publicado um pequeno conto nas páginas de $O$ Malho um ano antes do triunfante lançamento de Maleita (1934). "Cantiga de roda", a história de uma criança doente, o coloca de chofre na tradição social da literatura dos anos 1930. No enredo, uma família pobre, uma criança doente, um crime e a morte: para satisfazer um desejo do filho de apenas 7 anos que sofre de uma tosse rouca pneumônica, o pai, trabalhador pobre, furta um realejo para alegrar o pequeno. $\mathrm{O}$ roubo redunda em sua prisão por um rico promotor. A criança, entretanto, ganha ainda em vida um presente, e o som metálico do brinquedo o leva a divagar sobre mundos fantásticos e desconhecidos. Nem por isso a doença arrefece.

A desgraça e o fracasso estão estampados na pobreza do cenário, no casebre, no berço da criança, no corpo raquítico, nos afazeres da mãe e na impossibilidade do pai, como provedor, de dar um fim digno ao filho que sofre e morre. O herói, como na engajada literatura social daqueles anos, é a exibição crua da miséria e da luta (nesse caso velada) entre classes. Não é o pai preso, a mãe cansada e fracassada na manutenção da vida do filho, tampouco a criança, que a cada dia perde um pouco de vida. $\mathrm{O}$ embate social, entre a mãe pobre, fracassada, contra o promotor, rico e insensível, funciona como a vingança da miséria sobre a riqueza. Sendo que o ápice, o "efeito único", está justo no momento em que o promotor, em busca da prova do crime, o objeto roubado, observa não apenas o menino, mas sua entrega à morte.

O promotor sentia que a morte estava dentro daquele quarto, olhando aquela miséria. Esfregava os olhos e tentava compreender aquela vida, de tão imensa amargura, de uma pobreza diferente do que aquela que vira descrita nos livros. Mas no silêncio do quarto, notas de música, música ingênua, de criança, soaram. Coisas de roda, de crianças felizes, que ainda não conhecem a vida e cantam em torno das árvores...

Mas aquele coitadinho, aquele pedaço de carne talhado para o sofrimento e para a angústia, como único consolo, ouvia falar de riquezas que jamais possuíra e escutava aquela música que só podia trazer saudades de alguma coisa.

O estertor crescia, crescia e chegava quase a dominar a música do realejo.

Subitamente ele ouviu que a mãe chorava. Soluços comprimidos rebentavam, misturados com a agonia do menino infeliz.

E, subitamente, o estertor parou. Os soluços diminuíram. A morte chegara. 
E no profundo silêncio do quarto, a música de pedacinhos de vidro soava triste, enternecida, saudosa...

Cantilena de roda, de crianças felizes, em torno de árvores frondosas...

Ficou a escutar, quase com encanto, a música ingênua que trazia sensações esparsas de campinas consoladoras, de fontes minúsculas e grandes paisagens onde pastam boizinhos de brinquedo...

Mas a mãe levantara-se, fechara a caixa e entregava-a ao promotor:

- Leve.

O homem fitou o cadaverzinho, tão pequeno e magro que mal se distinguia da colcha de farrapos. Sentiu a vergonha e o remorso queimarem-lhe as faces, uma repulsa por si mesmo impulsioná-lo para a rua.

E o promotor elegante, escondendo na manga do paletó lágrimas vergonhosas, lágrimas que ele não compreendida, fugiu para a luz gloriosa do dia (Cardoso, 2012, p. 42).

Este talvez tenha sido o único conto de Lúcio Cardoso em que a temática social estabeleça por completo na narrativa, embora o autor nunca tenha abandonado os personagens excluídos (vide Timóteo, em Crônica da casa assassinada, e Clara, em Dias perdidos) e as tensões imanentes. Outros insumos, já presentes nesse pequeno texto fundador, foram levados para toda a sua literatura, tais como a fuga da vida por meio da morte e uma melancolia doentia que arrasta os personagens até o seu fim.

A geração de escritores dos anos de 1930 a 1950 tiveram os jornais como suporte para suas histórias e como meio de trabalho. E a literatura era recebida com colunas e espaços cada vez mais dedicados e especialistas. Lúcio Cardoso, que na década de 1930 vivia como empregado de uma seguradora, a Metrópole, com o passar do tempo foi se tornando colaborador frequente dos jornais $\mathrm{e}$ revistas. Suas primeiras colaborações literárias são da década de 1930. Recuperamos em nossa pesquisa contos do período publicados nas revistas $O$ Malho e Acadêmica, em O Jornal e na Folha da Manhã. E a história mais remota que localizamos foi justo a "Cantiga de roda".

Após a leitura desse conto, em que a suavidade e a fantasia da infância são contrastadas com a doença, a pobreza e o desespero dos adultos, constatamos que o entusiasmo de seu primeiro editor, o poeta e empresário Augusto Frederico Schmidt, responsável pela publicação de suas primeiras novelas, não era despropositado. Schmidt viu em Cardoso não apenas um jovem autor trazendo frescor e mocidade à literatura, mas um escritor pronto e pouco afeito ao estilo literário predominante na época. É essa a sensação que temos ao ler "Cantiga de roda", conto de cunho realista, embora extremamente lírico. 
A produção dos "contos gerais" de Lúcio Cardoso esteve concentrada entre as décadas de 1940 e 1950 no suplemento "Letras e Artes", de A Manhã. Parte foi mapeada pelos pesquisadores da obra cardosiana, como Mario Carelli - um dos primeiros a se voltar academicamente para a obra de Lúcio, na década de 1980 -, Ésio Macedo Ribeiro e Cássia dos Santos, ambos da geração 2000. Entretanto, até a publicação de Contos da ilha e do continente (Cardoso, 2012) não se sabia de que tratavam aqueles textos. As listas bibliográficas sempre acompanharam os perfis literários sobre o escritor, mas até então não havia uma pesquisa que apontasse o conteúdo dos textos listados.

No período de 1933 a 1959 foram encontrados 31 contos em jornais e revistas, dos quais 25 foram publicados em Contos da ilha e do continente. Verificamos a presença de seus contos nos seguintes periódicos e em ordem cronológica de aparição: O Malho, Acadêmica, O Jornal, Folha da Manhã, A Manhã, suplemento "Letras e Artes", Jornal de Letras, Revista d'O Globo, O Estado de S. Paulo. De todos os contos encontrados, apenas um foi descoberto numa antologia, sem qualquer ocorrência nas páginas de jornal e revistas: trata-se de "Carnaval de antigamente", publicado em 1945 na Antologia de Carnaval, livro da editora de $O$ Cruzeiro.

Para melhor entendermos os contos, aplicamos, para a análise, cinco itens gerais: o ano de publicação; o gênero e tipo de personagens dominantes, se homem, mulher, casal ou criança; a situação social ou o estado de espírito dos personagens, tais como recorrentes em seus romances e novelas: felicidade, pobreza, se proletário, doente, louco, fracassado e se há a presença da morte; o gênero e o tema geral, se regional, íntimo, filosófico/memória ou fantástico. Também inserimos em nossa lista o tipo de paisagem ou cenário que prevalecem: se num cais, no mar, se é urbano ou rural. E, por último, se o narrador é em primeira ou em terceira pessoa.

Da totalidade dos contos listados, $84 \%$ têm mulheres como personagens principais e $74 \%$ homens, sendo que em muitos casos mulheres e homens são igualmente personagens principais, e em $35 \%$ dos contos são casais que surgem em primeiro plano. Nessa análise percentual e sociocultural encontramos algumas curiosidades: em mais da metade dos contos (52\%) temos personagens fracassados diante da vida social, afetiva e, sobretudo, financeira. Pessoas alegres, felizes, só surgem em "Simples encontro", um dos 31 contos lidos e analisados 
que tem como personagem principal uma adolescente e o mar como cenário. A temática social, com a qual o escritor se debateu na década de 1930 e foi inquirido pelos críticos, também só aparece no primeiro conto publicado pelo autor, não retornando ao seu interesse nas décadas seguintes. Em contrapartida, contos com fundo filosófico e que têm a memória como fio condutor do enredo perfazem $48 \%$ dos textos, nos levando a crer que Lúcio Cardoso foi um autor de muitas memórias, seja autobiográfica, como podemos ver no romance Dias perdidos, seja a memória inventada para e pelos seus personagens. E, por último, vale a pena ressaltar dois aspectos importantes dessa obra: mais da metade (52\%) de seus contos, como suas novelas satânicas, são urbanos; é quando a cidade, o Rio de Janeiro suburbano e central, aparece. Em 32\% deles surge o mar como cenário inusitado, tanto em seus romances, como em suas novelas. E, por último, verificamos que $42 \%$ dos contos são narrados na primeira pessoa, enquanto o restante, $58 \%$, na terceira. E a morte surge em $39 \%$ dos textos.

No início, na década de 1930, Lúcio era um jovem autor navegando nas águas da incerteza estilística, tateando seu universo de possibilidades temáticas. Nessa fase encontramos uma literatura com resquício regionalista convivendo com temáticas urbanas. Mas, na década seguinte, os cenários urbanos sobressaem sobre o rural. Desde sua primeira narrativa curta até a última, em final da década de 1950, uma cidade decadente, suburbana, surge com seus sobrados gastos, mansões abandonadas e divididas em cubículos sujos, vielas de bairros centrais como a Lapa, as casas de vila da Aldeia Campista, bairros à beira do mangue e os locais de passagem, como o Cais Faroux e as Barcas, no centro do Rio de Janeiro. Cenários recorrentes também nas novelas satânicas Inácio (1944), O enfeitiçado (escrito em 1947 e publicado em 1954) e Baltazar (cujos capítulos foram publicados como folhetim em 1950).

Nos $23 \%$ dos contos que se passam em ambiente rural, surgem ícones já presentes na ficção cardosiana, tais como velhas casas de fazenda, pastos gastos, cidadezinhas mineiras, portões largos, cincerros chacoalhando no pescoço dos animais, cheiro da terra, a esperança evocada nas cintilantes folhas cristalizadas pelo sereno e toda essa ideia de um triste, empobrecido e angustiante interior, expresso na maioria de seus romances.

Além dos cenários urbanos e dos rurais do interior provinciano, encontramos os surpreendentes textos que se passam à beira-mar ou numa ilha 
(que suspeitamos ser Paquetá, citada abundantemente não só em seu diário, como também nas páginas do "Diário-não-íntimo", coluna de A Noite). São textos como "Os náufragos", "Junto ao mar", "O afogado", "Simples encontro", "Acontecimento da noite", "Aventura”, "O viúvo", dentre outros. E, por último, analisaremos os dois únicos textos fantásticos do autor. Esses textos longos maiores que os demais publicados na coletânea - merecem nossa atenção por serem raros na obra Lúcio Cardoso, mas também pelo fato de o tema ter perpassado de maneira insinuante toda a sua obra.

Se a presença do mar nos causou surpresa, a existência dos textos fantásticos nos chamou ainda mais a atenção. Veremos que Lúcio nutria grande admiração por Edgar Allan Poe, a quem dedicou alguns ensaios, coligidos ao longo da pesquisa. E, de certa maneira, podemos afirmar que o gênero fantástico foi determinante em algumas passagens dos livros da trilogia "O mundo sem Deus". Os contos "A escada" e "Olhos mortos" terão análise própria, pois desvelam essa faceta do escritor.

\section{A busca e o encontro dos não contos}

A pesquisa pelos contos de Lúcio Cardoso nos consumiu cerca de dois anos e meio e foi feita majoritariamente na Hemeroteca da Biblioteca Nacional, na Academia Brasileira de Letras e na Fundação Casa de Rui Barbosa. No período de nosso trabalho o arquivo digital da Biblioteca Nacional, com sistema de busca, ainda não estava em funcionamento, dificultando sobremaneira o levantamento dos textos, principalmente dos "contos gerais", que se encontravam espalhados em vários jornais e revistas de pelo menos três décadas diferentes. Usamos como metodologia a leitura de toda, ou de boa parte, do arquivo do escritor e de sua irmã Maria Helena Cardoso, que se encontram no Arquivo Museu da Literatura Brasileira da Fundação Casa de Rui Barbosa. A partir dessa pesquisa minuciosa em conjunto com a leitura da bibliografia sobre o autor, em que são citados alguns textos - levantamos as primeiras incidências em jornais e revistas coletadas sobretudo pela irmã de Lúcio. Com esse material, fizemos uma lista dos principais periódicos em que poderiam surgir os contos, e a partir desses títulos buscamos, 
ano a ano, mês a mês, dia a dia, os textos do escritor. Essa primeira parte da pesquisa, a mais longa, foi toda voltada aos "contos gerais".

Os contos de crime publicados na coluna "O Crime do Dia" e "Novelinha do dia a dia" são frutos de outra descoberta. A coluna "O Crime do Dia" foi encontrada num simples recorte, sem data, anunciando a estreia do autor em uma nova coluna do jornal A Noite. A partir desse recorte localizamos a coluna nas páginas do jornal - descoberta, aliás, muito celebrada, uma vez que até então se ignorava a existência da coluna e dos 265 contos escritos por Cardoso sobre o crime e a cidade do Rio de Janeiro.

Em meio a essa busca, encontramos textos do escritor de outros gêneros - e textos publicados como contos que eram trechos de novelas e romances. E o mais interessante: Lúcio republicava seus contos com outros títulos, quatro, cinco anos após a primeira edição. Fazia pequenas mudanças e o republicava com um novo título. Ao longo desse levantamento encontramos colunas literárias e mundanas assinadas pelo escritor em diversos jornais e que, agora, sairão em livros. Também localizamos uma produção enorme de crítica literária sobre livros e escritores brasileiros, além de perfis de poetas e romancistas estrangeiros que, um dia, merecem ser publicados não só pelo seu valor histórico e literário - afinal, era a recepção de outras literaturas entre os brasileiros e a sua visão sobre seus pares , mas pelo cuidado analítico e narrativo desses artigos. Todos também inéditos em livro.

\section{Trechos e contos}

Desde a juventude Lúcio publicava trechos de seus romances como contos independentes. Em 1935, a revista Lanterna Verde publicou "Confissão" e anunciava, no pé de página, que se tratava de parte de Salgueiro, publicado no mesmo ano. Mas nem sempre o escritor e seus editores fizeram essa importante ressalva. Ainda em 1935 é publicado, na revista Acadêmica, como conto, "História do sertão", trecho de no 29 de Maleita. Três anos depois, em 1938, sai em O Jornal o conto "A morte de Matheus" - ilustrado com belo desenho de Santa Rosa, com quem anos antes Lúcio havia criado a Sua Revista. Dois anos depois, em 1940, publica a novela Céu escuro como separata da Vamos Ler! 
Percebemos daí que o conto publicado em 1938 faz parte da primeira parte da novela. Mas a saga continua: em 24 de novembro de 1940 sai no Diário de Notícias o texto "Um capítulo de romance", que vem a ser o excerto que faltava à novela Céu escuro, quase um capítulo final, pois narra o acerto de contas de um dos personagens, o irmão sobrevivente, com o que ficou da memória de sua vida na casa paterna, da lembrança de sua irmã e da relação tumultuada com as empregadas. Mas, quatro anos depois, em 1944, o escritor ainda publica em $A$ Manhã os contos "Diante do rio", "História de Cristiana" I e II, que de alguma maneira fariam parte da trama de Céu escuro. Desde o cenário, passando pelas personagens e a descrição da memória sufocante de tempos de tirania patriarcal, encontramos nesses trechos passagens inequívocas e perdidas de Céu escuro. Mas não há qualquer menção ao fato, e os textos foram publicados como contos independentes de qualquer história maior. Essa prática recorrente demonstra como Lúcio tratava o material para a publicação na imprensa, isto é, com absoluta falta de critérios. Céu escuro saiu em separata da revista Vamos ler!, em 1940, e não foi republicada por ele em vida. Os textos esparsos continuam separados e não houve nenhuma indicação - apesar das óbvias incidências - de que deveriam ser publicadas em conjunto.

Dos muitos casos pitorescos de edição e reaproveitamento de contos, o que nos causou imensa curiosidade foi "O regresso", publicado em O Jornal, também em 1938. Os personagens da história - Ida e Felipe - são os mesmos da novela Mãos vazias, que saiu naquele ano; o ambiente é idêntico, a tensão entre o casal idem, mas o conto não faz parte da novela e não surge como continuação, é apenas a reutilização do cenário e dos personagens para uma nova história.

Da década de 1940 encontraremos também a publicação de trechos de futuros romances que nunca deixaram a gaveta, é o caso de "Um capítulo de novela inédita", em 13 de fevereiro de 1944, no jornal A Manhã. Identificamos o texto como parte dos manuscritos incompletos de uma novela - jamais realizada. O texto se encontra na pasta LC 31 pi, do Acervo de Lúcio Cardoso no AMLB da FCRB, com o título de $O$ riso escuro ou o pavão de luto.

O levantamento dos contos nos levou inevitavelmente ao processo da sua escrita, a sua busca pelo acerto em meio aos erros, desistências e demonstração de uma incrível persistência para encontrar sua melhor história, mais perfeita até, e, sobretudo, do que a vida. Mas demonstra também total desapego ao gênero conto, 
usado parte das vezes para desaguar histórias incompletas e testar novos ambientes, bem como criar a partir de histórias já existentes e publicadas, como os casos de Céu escuro e Mãos vazias, repetições e desdobramentos de um mesmo universo, sem fim específico, dando a esses escritos uma estranha autonomia. A serialização dessas histórias se torna uma prática vinculada muito menos a ideia de continuação e repetição de um roman fleuve, afinal não foram publicadas enquanto tal. E se aproximam muito mais da serialização de folhetins e outras narrativas que derivaram da experiência do escritor na imprensa diária moderna.

\section{Entre 1940 e 1950}

No final da década de 1940, a vida de Lúcio estava longe da perfeição, ao contrário de sua literatura, que alcançava a cada dia uma sofisticação narrativa e poética como poucas da prosa brasileira, sempre muito descritiva e realista. Afasta-se da vida literária entre 1948 e 1949 e dedica-se ao cinema e ao teatro. Vê naufragarem dois grandes projetos profissionais e ambiciosos: a direção no cinema e a produção teatral. Retorna para a imprensa. Em meados de 1950, na Revista da Semana figura no expediente como "secretário" - abaixo apenas do diretor e redator-chefe - e publica, de 1954 até 1957, críticas literárias e longas reportagens sobre o sistema de águas e o trânsito ruidoso do Rio de Janeiro. No final da década encontramos colaborações para o jornal O Estado de S. Paulo.

Dentre os contos escritos neste período, um deles merece menção: "Basílio da Luz”. Após 1944, quando publica Inácio imbuído da ideia de criar grandes romances e novelas que se desdobrassem em trilogias, escreve na esteira $\mathrm{O}$ enfeitiçado e, em seguida, Baltazar, que seria a última novela da série "O mundo sem Deus". Baltazar, no entanto, permaneceu inédita e manuscrita. Em 2002, quando publicada pela Civilização Brasileira, não se sabia que a novela havia sido divulgada em oito partes em 1950. O primeiro título, "O delírio", referente ao capítulo 4 da publicação póstuma, é publicado em março, seguido por "Basílio da Luz", inédito até a sua aparição em Contos da ilha e do continente. Depois, em maio, veio "Capítulo de romance" (referente ao capítulo 2), "A cartomante" (capítulo 7) e, por último, "Flora" (capítulo 8). O conto para o romancista, como vemos, não era prioridade, mas um espaço de invenção, como aponta Bosi, e de 
apropriação, mostrando a plasticidade com que jornais e revistas do período entendiam e publicavam o gênero. O texto poderia, até, ser parte de uma história maior, mas naquele espaço do jornal, deslocado da trama do romance ou novela ao qual pertencia, ele funcionaria como conto. Pesava, além do efeito único, o tamanho e um desfecho para a trama.

\section{3 \\ Um mar, só fuga}

Como vimos em nossa pesquisa quantitativa, o conto de Lúcio Cardoso teria uma mulher como personagem principal, fracassada em sua vida afetiva ou social, com questões filosóficas que evocam sua memória história, e se passaria num cenário urbano. O conto, com todos esses elementos enunciados, existe. Podemos citar "Acontecimento da noite" ou "Novela humilde", mas, curiosamente, em ambos surgem elementos disruptivos: o mar e a praia urbanos.

Nos anos 1940, o escritor leva para a literatura sua paixão pelo mar e pelos encantos das ilhas, cenário inexistente em suas novelas e romances, cuja maior parte se passam no interior, na província, enquanto a cidade é local apenas da novela Salgueiro e das demais que compõem a trilogia "O mundo sem Deus". No cinema, onde estreou como diretor em Almas adversas (1948), o mar foi presença constante no longa inacabado A mulher de longe, filmado em 1949, em Niterói. Nesse período morou na cidade fluminense e tornou-se observador privilegiado das praias de Itaipu, das Flechas, Gradim e até de Maruí, praias de mar aberto, praias de fundo de baía, fétidas e habitadas pelo povo do manguezal, caiçaras em busca de alimento e urubus à espreita dos restos. A partir de dias e noites de observação, escreve em seu Diário completo:

Não sei porque tantos julgam que o mar é o símbolo da liberdade: vendo-o agora da minha janela, percebo-o como uma grande coisa aflita e aprisionada, lançandose sem descanso contra esses carcereiros imóveis que são os rochedos. Nada mais plangente em sua eterna queixa, em sua prisão perpetuamente agitada pelos ventos da distância. (Cardoso, 1970, p. 11). 
O mar de Lúcio desvenda e embala esse homem moderno, angustiado, aflito, que sobrevivia numa balança em que os pesos pendiam sempre irregulares entre as escolhas de uma vida e um deus traiçoeiro; os desejos e a religião; a realização e o fracasso. E tal como as dúvidas que cindiam a vida do escritor, sua escrita revela duas ou mais faces. Se o mar traduz essa "coisa limpa", 47 como descreve em seu Diário, as relações sociais humanas revelam um estado sombrio.

Esse suspeito mar surge na década de 1940, anos de guerra e de fracassos pessoais, mas também uma década de amizades, época em que conhece Clarice Lispector (ver Moser, 2009, p. 159), Fernando Sabino e outros jovens escritores e artistas, como a portuguesa Vieira da Silva (ver Lamego, 2007, p. 53) e seu marido, o pintor húngaro Arpad Szénes. Foram anos de amadurecimento, quando celebra os 30 anos, e produz incansavelmente, tendo publicado e escrito a maior parte de suas novelas e dos seus textos para o teatro. ${ }^{48}$ A redação para os jornais revelava essa pujante produção, tanto que $61 \%$ dos "contos gerais" datam deste período.

As primeiras lembranças do escritor sobre o mar vêm da infância, mas a força das águas como elemento ficcional e narrativo surge na maturidade, primeiro nos contos dos anos 1940, mais precisamente a partir da publicação de “Os náufragos”, em 1944, depois nas páginas de seu Diário completo e em seu filme inacabado e, por último, na coluna mundana de $A$ Noite, chamada "Diário não íntimo" (1956-1957), na qual o escritor demonstra aos poucos e, publicamente, seu fascínio pelas águas da Guanabara.

A primeira viagem que fiz para ver o mar, foi em companhia da minha mãe. Ela falava em Botafogo, íamos de bonde, mais dois ou três quarteirões adiante, senti que havia uma transformação no ar - como um cristal a atmosfera parecia tremer. - Já se pode ver alguma coisa - avisou minha mãe.

E eu, mineiro, esforcei-me por enxergar as distâncias da Glória - nada vi, mas de lá, como um hausto de alguém enorme e em constante luta contra o paredão, vinha

\footnotetext{
47 "O mar, a proximidade do mar torna todas as coisas mais limpas. Lembro-me de Congonhas do Campo, tão pobre quanto as mais pobres aldeias de pescadores que ora visito nos arredores de Niterói - e nenhuma delas possui aquele ar de sujeira e de moléstia, que tantas vezes surpreendia na velha cidade de Minas." (CARDOSO, L., 1970, p. 12).

${ }^{48}$ Pouco se escreveu sobre o teatro de Lúcio Cardoso, mas Mario Carelli, em Corcel de Fogo, citou algumas passagens. Ver CARELLI, M. (op. cit., p. 55).
} 
aquela brisa onde era possível se distinguir vários odores novos - e até mesmo um perturbador cheiro de sangue. ${ }^{49}$

O trágico, o perturbador e as memórias marcaram a literatura de Lúcio Cardoso, até mesmo quando o escritor evoca seu primeiro contato com o mar. As reminiscências infantis escritas na sua coluna de faits divers é apenas uma das muitas vezes em que as águas da Baía de Guanabara e do Oceano Atlântico estiveram presentes na sua obra. É esse elemento novo que rompe com a tradição da literatura de província.

Entre as décadas de 1940 e 1960, elegeu Ipanema, bairro boêmio, com intensa vida à beira-mar, como seu lugar, e lá viveu, palmilhou suas ruas estreitas entre o mar e a lagoa até morrer, em 1968. Por um longo período buscou neste cenário uma satisfação e um prazer conflitantes com o opressor interior mineiro. E ainda mais incompatível com os cenários de seus romances pós-regionalistas, todos vividos em pequenas cidades, de ruas soturnas, em noites e casa seculares igualmente escuras e envelhecidas, onde a marca do tempo e a ausência de luz são frequentes. Foi assim em A luz no subsolo e em Mãos vazias. Mesmo nas novelas urbanas, a mesma "atmosfera" ${ }^{50}$ se repete. O mar, entretanto, estava latente em sua vida e representava um ponto de estabilidade entre dois paradoxos: a cidade e a província. A ilha de Paquetá, na Baía de Guanabara, foi cenário de muitas histórias, sendo local de descanso, das férias prazerosas, lugar bucólico e destino dos convalescentes das tantas doenças que assolavam personagens da literatura naqueles dias. Ainda em sua coluna "Diário não íntimo" escreveu, em 4 de janeiro de 1957:

Não é sem emoção que piso Paquetá, desde que ali aportei, já lá se vão muitos anos, quando a ilha, inédita, sorri ao meu primeiro deslumbramento de menino [...]. $\mathrm{O}$ mar, que bate junto às pedras é sempre novo. Esta lancha sem serventia, cognominada "Mércia"; que descansa à sombra de um flamboyant - pintura que ninguém pintou [...]. Anoitece. E anoitecendo, Paquetá é bonita de qualquer modo. Há estrelas nascendo na barra distante, e o vento que sopra traz esse bom cheiro de velhas quintas, onde à salmoura característica, mistura-se o cheiro familiar da

\footnotetext{
${ }^{49}$ CARDOSO, L. "Diário não-íntimo". A Noite, 1.10.1956. AMLB/FCRB.

${ }^{50}$ Sobre a atmosfera: foi o crítico Tristão de Athayde que cunhou a frase que Lúcio Cardoso não era apenas um romancista, era um criador de atmosferas. Ver CARELLI, M. (op.cit., p. 13).
} 
murta e da hortelã e qualquer coisa agreste e fechada, que dá à ilha poente não sei que vago tom de mistério primitivo e vegetal. ${ }^{51}$

Nos contos, Lúcio Cardoso dedicou especial atenção às mudanças das marés, à bruma baixa colada à lâmina d'água nas madrugadas, ao cheiro acre da maresia, à espera solitária dos amantes nos portões das barcas, que cruzam até hoje a Baía de Guanabara, entrada do Rio de Janeiro. E o ir e vir dos anônimos nos lugares de passagens, nos não lugares de então, o cais, as barcas, onde personagens suicidas e desoladas ancoraram suas vidas na narrativa cardosiana.

Embora em suas conhecidas novelas e romances não exista essa vida marítima, sua obsessão pelas águas fluminenses é recorrente e de certa forma contradiz a crítica realizada pelos seus detratores de plantão. Em meados na década de 1940, numa batalha com o articulista e escritor Clovis Ramalhete sobre suas opiniões acerca da Segunda Guerra expressas em "Confissões de um homem fora do tempo", recebe a seguinte crítica no texto chamado "O sapateiro e a guerra".

\begin{abstract}
Adotou um "tom noturno" na ficção desse país de sol, pedras coruscando, cactos, secas e crimes passionais, confundindo erro com originalidade. E descansou serenamente sobre as certezas de sua obra. Não sofre de insônia e jamais duvida de si próprio, esse inabalável. ${ }^{52}$
\end{abstract}

\title{
"A ilha" ou "Junto ao mar"
}

Na ilha de Lúcio Cardoso existe o "país de sol”, de dias ensolarados, de luz intensa e frescor, que se alternam com manhãs sombrias, chuvosas. Seus personagens - fracassados - sobrepõem suas subjetividades à convivência com o real. Não há na literatura brasileira uma visão tão intimista quando o espaço é o mar, a praia, ou a ilha que em Lúcio está léguas de distância de qualquer regionalismo causticante, apesar de, em ambos os gêneros, os personagens serem doentes, excluídos, marginais e náufragos. A ilha, mais do que um refúgio num remoto (às vezes aprazível) torrão de terra cercado por água, é também o lugar de

\footnotetext{
${ }^{51}$ CARDOSO, L. "Diário não-íntimo". A Noite, 4.1.1957. AMLB/FCRB.

${ }^{52}$ RAMALHETE, C., "O sapateiro e a guerra", circa década de 40, Arquivo Lúcio Cardoso, AMLB, Fundação casa de Rui Barbosa.
} 
confinamento, recolhimento, restrição e marginalidade. A ilha mantém o indivíduo afastando do continente, da província ou da cidade. Da família ou da civilização devoradora.

Da cama, ele escutava a chuva bater duramente a terra do quintal. Através do vidro, as ramagens sombrias se agitavam no grande vazio em que o dia começava a nascer. Um sentimento sufocado e áspero parecia crescer do lado de fora e estreitar o pequeno quarto onde ele se achava deitado - e, com os olhos abertos, sentia aumentar na sua consciência a sensação da inutilidade daquela viagem, o repouso fracassado, o combate inútil contra a febre e o termômetro obstinado... E não lhe tinham dito que aquela era a sua grande oportunidade, que voltaria curado da tuberculose, com novas forças, pronto para reenfrentar a luta igual, a luta armada, a ambicionada luta de todo o mundo?...

Não, decerto jamais saberiam o que era aquela espécie de solidão, aquela densa, pesada, amarga solidão de alguém que traz em si a consciência de uma falta cometida — pois há também a solidão dos sanatórios, mas esta é uma solidão de que participa um pequeno mundo, como há a solidão particular, no mundo sem doenças e sem termômetros. Mas o terrível era estar assim isolado, doente, num mundo de pessoas sãs, onde jovens fortes - jovens da mesma idade que ele transitavam em roupas de banho ou jogavam tênis no pátio com moças ousadas e maravilhosas. (Cardoso, 2012, p. 64)

Assim Lúcio inicia o conto "Junto ao mar", escrito em 1946, para o suplemento "Letras e Artes" e republicado no mesmo suplemento quatro anos depois. "Junto ao mar" é um exemplo de conto que, anos após a primeira edição, reapareceu com novo título e alterações. Sua primeira edição chamou-se "A ilha", e em 1950 ganhou o título que consideramos definitivo. Neste conto, um rapaz recupera-se de uma grave doença num hotel à beira-mar e descobre a vida laboriosa e cheia de expectativas dos pescadores locais. A sua fraqueza e vida mitigada pela doença contrastam com a alegria exuberante dos hóspedes em férias e com a força bruta dos pescadores que se preparam para mais um dia no mar. Chove, as janelas estão fechadas, e os vidros turvos pelas gotículas. Mas nada o impede de buscar esta outra vida, e é a partir da ideia de evasão e de encontro com o novo, revelador de outra realidade, que está centrada a narrativa.

Oh! fugir, fugir dali o mais depressa possível! Ser uma vez ao menos como os outros, ter um amigo, ir pelas ruas indiferentes ao tempo, ser ousado e livre como um animal! E quase sem saber o que fazia, arrastado pelo descontrole dos seus sentimentos, abandonou a varanda e desceu a escada.

Uma súbita trégua se tinha feito no tempo: só os troncos negros escorriam. Ganhou o portão e daí se encaminhou para a praia. Barcos de pescadores, prontos para a partida, balançavam-se ao longo da amurada semidestruída. Era de lá que vinha a 
voz que o atraía, era de lá que vinha aquele tremendo, enervante apelo. Avançou, sem sentir o vento frio que lhe cortava o rosto. E, ainda que o sentisse, que the importava aquilo? Tudo, em torno, parecia recender e se mover num surdo arquejo de vida e de esperança. E lá estava o homem que cantava, o homem forte, dobrando a rede sobre a popa de um dos barcos. Era dele, só podia ser dele aquela voz. Tipo estranho e saudável, impregnado pela essência daquelas coisas que o cercavam, redes e estacas, velas, anzóis pendurados ao longo da amurada. Moreno, mas seus cabelos eram louros, um louro queimado, de gente acostumada a atravessar dias sobre o alto-mar. Aproximou-se timidamente, se bem que no fundo todo ele fremisse de inquietação e sofrimento...

- Eh moço, parece que o tempo vai amainar... - disse o pescador à guisa de saudação.

Respondeu, a voz travada:

- É...

Viu como o pescador manejava habilmente a rede complicada, como seus pés se afundavam na areia, cobiçosos, talhados em dura e passiva dignidade. Jamais compreendera como se pudesse viver assim, tão áspero e tão destemido ante a hostilidade das coisas - era talvez e porque a alma toda lhe fosse naquilo, uma ardente e misteriosa alma de criança, cheia dos segredos e das formas marítimas, como um grande mapa ainda não percorrido pelas correntezas fortes da solidão e do desespero.

— Vai pescar hoje? - indagou.

- Há garoupeta perto daqui - respondeu o outro. E acrescentou: - Não é viagem longa. (Cardoso, 2012, p. 67)

Apesar das mudanças de título, a narrativa permanece praticamente a mesma, com pequenas alterações. Na última e definitiva versão, não importa mais se aquele lugar pertence ou não ao continente, o que diminui o grau de isolamento de seus personagens. E a doença do rapaz, antes irrelevante, agora é identificada como tuberculose. As mudanças são poucas, mas acreditamos que, a título de exemplo, seria interessante citá-las para o entendimento da construção do escritor e de seu modus operandi diante do texto:

$\mathrm{Na} 9$ a linha do terceiro parágrafo, um possível erro e concerto. "Olhar ao longo lamentoso das águas ao longo das valas cheias", ganhou nova redação: "Olhar o escorrer lamentoso das águas ao longo das valas cheias". De fato a repetição da palavra "longo" não fez bem aos ouvidos do autor quatro anos depois. Na abertura do quarto parágrafo, a palavra "levantou-se" foi substituída por "ergueu-se". E na 14 linha do mesmo parágrafo, uma alteração interessante. Na primeira edição, "um cheiro novo de café errava", não menciona a palavra "ambiente" e a ênfase estava no cheiro novo e não no prosaico café, como agora: "Um cheiro de café novo errava no ambiente". Nos parágrafos seguintes aparecem frases e situações novas, certificando-nos de que as mudanças foram realizadas pelo autor e não pelo editor do suplemento. No final do quarto parágrafo, surge 
um canteiro inexistente: "e que do canteiro baixo grimpava pela parede até as bordas da grade". E um gesto impensado: "Insensivelmente a flor tombou de suas mãos, esteve suspensa ainda um minuto num dos galhos e, finalmente, caiu numa poça de água suja, onde ficou revoluteando". No final deste, o personagem, antes pacato e triste, é "arrastado pelo descontrole dos seus sentimentos", demonstrando uma faceta inusitada do doente na primeira versão. Outras pequenas mudanças são aqui e ali encontradas: o cabelo avermelhado do pescador ganhou um tom de "louro queimado". E uma última frase, nova e tão cardosiana que nos exime de dúvida sobre a autoria das mudanças:

"Só os rochedos pareciam maiores no silêncio do mar"

A nova redação, além de mais detalhista e limpa, denota uma linguagem mais poética, com expressões escolhidas com precisão. A mesma situação de "A ilha" e "Junto ao mar" se repete em "A papoula azul", que quatro anos depois se transforma em "Simples encontro", e em "O pátio", rebatizado também quatro anos depois de "Aventura". O mar ainda surge nos contos "Os náufragos", "O afogado", "Acontecimento", “Andorinha", "Novela Humilde" e "Acontecimento da noite".

É surpreendente que essas narrativas cardosianas tenham passado anos distantes do público e totalmente desconhecidas da literatura brasileira, uma vez que somente em 2012 foram publicadas em livro. Nesses contos citados até agora, há uma pequena dose de literatura fantástica, mas nos textos mais longos "“Olhos mortos" e "A escada", a fatura é totalmente imaginosa e filiada inequivocadamente ao gênero. Além da inverossimilhança discutida por Bandeira lá trás, temos nos contos gerais de Lúcio um perpétuo sentimento de evasão, o desvelo da inocência a partir de eventos trágicos e a imposição da solidão, muitas vezes como consequência do encontro com outra realidade. Em "Junto ao mar", por exemplo, o personagem principal, um jovem que tem turbeculose, se fecha em sua solidão enferma ao tomar contato com a vida laboriosa do pescador que encontra na ilha. 
- Adeus, adeus! - murmurou o rapaz, baixinho. E lentamente, como se uma fina lâmina tivesse penetrado em seu coração, ganhou de novo o caminho do hotel. A febre fazia-o tremer. E jamais, jamais sentiu a ilha tão pequena, quanto naquele instante a sentia fechar-se inteira sobre o seu sofrimento. (Cardoso, 2012, p. 69)

Encontramos de maneira tênue a presença do universo fantástico em contos como "Simples encontro (A papoula)" e "Andorinha". Neste último, nos primeiros parágrafos somos levados a crer que a personagem que dá nome à história, a menina Andorinha, é (ou age como) um fantasma:

Ainda a vejo, se fechar os olhos. Mas já sem realidade, como um ser que apenas acabamos de deixar, que podemos encontrar de novo daqui a pouco, que nos espera, que ainda pode rir e estar conosco. Apenas como um fantasma, o eco de alguma coisa que teve vida, que um instante - há tanto tempo - palpitou junto a nós, fez soar na distância seu riso matutino, falou apenas algumas palavras... Triste criatura vinda do exílio e do abandono, alma informe e corpo mal iniciado em seu obscuro desabrochar, chamava-se Lili, Helena, Mariana, não sei mais... (Cardoso, 2012, p. 123)

"Andorinha" foi publicado em abril de 1948, no suplemento "Letras e Artes", portanto, após a publicação dos contos-novelas puramente fantásticos “Olhos mortos", de 1946, e "A escada", de 1947. Em "Andorinha" a sensação da presença de seres não vivos, sobrenaturais, flutuando sobre a vida, pobre e real, não passa de uma forma de representação da memória do narrador. Mas a influência do fantástico sobre a história da menina, abandonada pela mãe, que encontra refúgio na casa de uma velha tia, onde passa seus dias entre os animais do quintal e estranhos personagens por ela inventados, é notável.

Concordemos que tenha sido Lili, que eu a tenha encontrado na ilha há muitos anos, que ela me esperasse do alto da escada, toda vestida de preto, um avental branco amarrado à cintura, uma parte mais alta cobrindo-lhe o busto. Aí está: por isto é que a chamávamos simplesmente de Andorinha. Porque, toda de preto, debruçada na alta varanda de nossa casa senhorial, a cavaleiro numa das encostas mais belas da ilha, parecia prestes a alçar vôo, o peito branco arfando de ansiedade, de vida estranha e infantil. Era no inverno, chovia, todo o mar era um vasto mundo de cinza e bruma. Cabelos soltos, Andorinha olha e via decerto o que ninguém via: a memória do sol no outro lado da baía, o adeus das últimas barcas que partiam, sons desgarrados pelo ar e que não chegavam a se constituir em música. Nada se movia em nosso jardim, entregue ao vento e à chuva, uma dessas chuvinhas persistentes, antipáticas, e que já durava há vários dias. (Cardoso, 2012, p. 123124) 
Andorinha é melancólica e triste, como várias personagens do escritor. Em sua história, as perdas e a substituição da memória por uma falsa memória inventada são constantes. Mas além desses aspectos outros dois estão fortemente presentes: a ideia de despaisamento e de território de passagem. Tanto o narrador, o médico, como a menina, abandonada, estão naquele lugar temporariamente e sua relação é medida por esse tempo e pela sensação de não pertencimento àquele lugar. O sentimento de "despaisado", mencionado antes por Mario de Andrade em sua análise de $A$ luz no subsolo é, agora, objeto da própria observação do escritor: "triste criatura vinda do exílio e do abandono". Nestes textos curtos, seus personagens sofrem desse sentimento de imprecisão e não pertencimento, ilhados numa terra circundada pela realidade dominante. O desfecho em "Andorinha" é de abandono e de entrega ao amor ou à morte, com a menina se lançando nos braços do médico oferecendo seu corpo e/ou a sua morte, repetindo o mesmo destino de sua mãe, continuando assim o ciclo de fatalidade e opondo-se radicalmente à ideia de liberdade ou de conquista da mesma.

\begin{abstract}
Coloquei-a no chão, bradando: Então, selvagem, ela se abraçou a mim, soluçando: "Leve-me, serei tudo para você, servirei até de criada. Não sabe ainda que eu o amo, que o amo como a mais ninguém neste mundo?" Desprendi-me, afastei alguns passos, estupefato. Não, não podia compreender, as paixões eram naquele tempo um terreno vedado ao meu conhecimento. E como podia imaginá-las naquele precoce coração, naquela triste alma que já se revelava tão ardente e solitária? Sei apenas que de repente entrevi um abismo naquele pequeno ser desmantelado, naquela miúda figura trêmula de febre, que me fitava cheia de angústia, o rosto inundado pela chuva. Cheia de angústia, mas também de sentimento e de coragem. Nela vi então a imagem da prima que fugira, seu destemor, sua paixão, sua alma estranha. Tudo renascia em Andorinha, também misteriosa e agreste. Qualquer coisa rompeu-se dentro de mim, senti-me tonto, apertei-a entre os braços com uma força que desconhecia, exclamando: "Criança! Criança! Criança!” (Cardoso, 2012, p. 130-131)
\end{abstract}

Um dos mais belos textos dos contos gerais, "Simples encontro" ou "A papoula azul", traz pela primeira vez nestes textos curtos a ideia de felicidade. Léa, personagem e narradora principal, é uma jovem de 14 anos, gregária, alegre e afetuosa e, em torno dela, reúnem-se os amigos: 
- Léa! Léa! - gritaram assim que me viram. - Que trouxe você para o nosso almoço?

E sem esperar resposta, puseram-se a dançar em torno de mim, saltando e batendo palmas.

Juntos partem para um dia numa das mais belas praias da ilha (essa ilha sem nome) e levam consigo morangos doces e outras guloseimas para um piquenique. A felicidade é a tônica da primeira parte do conto, o mar brilhava, mas o vento contrastava "com a sombra que os rochedos da ilha projetavam na água".

Maravilhadas, deixávamos que nossas pegadas se imprimissem na areia mole. $\mathrm{O}$ sol, mais alto, fazia verberar intensamente toda a vasta extensão do mar.

— Não nos afastemos muito - propus eu - talvez os outros cheguem e não nos encontrem.

De fato, outros companheiros vinham chegando: Eduardo e a irmã, Rosa e Marcelina. Ao todo éramos sete e tínhamos combinado aquele piquenique para comemorarmos o início das férias. Oh, depois do longo período de estudos, como estávamos sôfregos por liberdade, ar livre, o vento e as praias! Como a ilha nos pareceu um recanto abençoado, com suas rochas, suas furnas, suas árvores, sua cabeleira verde, nativa e abençoada! Eu então, a quem a longa doença de meu pai retivera tantos meses à sua cabeceira, olhava para tudo aquilo com um verdadeiro sentimento de embriaguez. Uma energia nova despontava realmente no meu íntimo - e isenta de cuidados, tonta, feliz, eu corria de um lado para outro, sentindo a minha alma se dilatar como se dentro dela penetrasse todo o azul do oceano. Corríamos - e tudo nos servia de pretexto para correr: uma onda maior que nos assustava, uma borboleta amarela que vinha do mato e se desgarrava na praia, um avião cortando alto e nítido a imensa placidez do céu... (Cardoso, 2012, p. 76-77)

Em meio à felicidade, às águas limpas e claras, surge um estranho elemento. Um homem vestido de preto observa as meninas e se aproxima de Léa lhe fazendo um simples convite:

- Não gosta de flores?, pergunta o sujeito. A que Léa responde: - Flores, gosto muito. Em busca da flor rara, de uma papoula azul, Léa, atraída pela diferença e pela curiosidade, se embrenha pela montanha com o homem estranho.

Naquele minuto, não sei se acreditava ou não que existisse entre eles uma papoula azul - sei apenas que o mistério daquele homem me atraía. Acompanhei-o. Por trás de mim, ouvia as risadas de meus companheiros, que se distanciavam. O homem caminhava na minha frente, curvado, ofegante, como se tivesse pressa. Seus dedos longos, agudos, agarravam-se à rocha como garras. Não tardou muito em que chegássemos ao alto. (Cardoso, 2012, p. 79)

O homem vestido de preto, solitário, de aparência triste e severa é o oposto da menina Léa e seus amigos. Como em "Junto ao mar", a inocência, aqui, é 
raptada pela tristeza e pela loucura. No alto da montanha o homem enterra um "comprido e negro espinho de cactos" no braço da menina, seu sangue escorre e mancha a pela clara. Não existe papoula azul e Léa grita horrorizada, enquanto o homem foge, corre, e escapa por entre as pedras.

Ele me fitou com olhos de que jamais me esquecerei, tão duros, tão cruéis se mostravam. Ao mesmo tempo que ele se revelava com esse olhar, não tive mais dúvida de que me achava na presença de um louco. (Cardoso, 2012, p. 80)

E assim se dá o rompimento do ciclo de felicidade e de inocência na ilha prazerosa. No encontro com o outro e com realidade adversa, os personagens de Lúcio Cardoso enfrentam a loucura, a felicidade e, sobretudo, a diferença, fazendo com que a solidão e a individualidade sobressaiam. E principalmente nos contos de ilha, os ciclos de inocência, de fracasso ou mesmo de expectativas são rompidos a partir do contato do personagem com outra realidade. Em "Novela humilde", a costureirinha do interior vê seu ciclo de solidão rompido por um novo amor, que a leva a uma gravidez e à exclusão social. Em "O afogado", o encontro com um morto na beira da praia faz com que uma devota rompa com o ciclo de fé e repense a vida casta. E em "Aventura", o homem de meia idade, ao encontrar uma linda jovem numa praia da ilha, rompe com sua tristeza e encontra sua velhice.

Nos contos fantásticos não há o rompimento de um ciclo a partir de um encontro ou de nova situação. O ciclo já está partido. Tanto em "Olhos mortos" como em "A escada", os mortos não vêm ao mundo dos vivos para transformá-los ou levá-los a outra experiência, eles vêm para relatar a sua experiência em vida e confirmar o seu encontro com a morte.

\section{4 \\ 0 continente fantástico}

Além das referências ao mar e de todos os seus significados, na década de 1940 Lúcio Cardoso flerta com a literatura fantástica de Edgar Allan Poe, levando 
a sua experiência com as novelas satânicas a um exagero hiperbólico nos contos “Olhos mortos", de 1946, e "A escada", de 1947.

Os contos foram escritos após a publicação de Inácio (1944), período em que fora tomado de uma grande admiração pela obra do escritor americano. Em 1944 escreve para A Manhã os artigos "Edgar Poe 1", "Edgar Poe 2" e "Edgar Poe (Conclusão)" em 12, 19 e 26 de julho, respectivamente; sob o pseudônimo de Graça Mello adapta o conto “O coração delator” para o teatro, em julho de 1948. A influência de Poe sobre Lúcio vai além da literatura e do teatro, pois o escritor brasileiro faz nestes artigos um defesa violenta do estilo de vida e comportamento tão combalido, nas sociedades conservadoras de então, do escritor americano. É evidente a presença de Poe naqueles dois contos, e também acreditamos que esses textos, únicos em tantos aspectos, são sua experiência "satânica" elevada ao fantasioso mundo da literatura fantástica.

O escritor americano, que teve bons leitores brasileiros neste período, como Lúcio e Guimarães Rosa, ${ }^{53}$ está presente no conto cardosiano na temática (a convivência com o sobrenatural; o espaço de confusão entre a morte e a vida; os mortos imiscuindo-se no mundo dos vivos), no desenvolvimento da narrativa, na revelação e sobreposições dos mundos, mas, sobretudo, no uso do famoso "efeito único", criação de Poe em suas narrativas fantásticas e de terror.

O efeito único ou o efeito singular define a narrativa moderna dos contos policiais e de suspense. Nesta técnica, todo o esforço do autor está na tentativa exclusiva de conduzir o leitor, do início ao fim da história, à revelação do enigma proposto. Edgar Allan Poe, segundo Cortázar, criou, a partir de sua engenhosidade narrativa, uma verdadeira "máquina literária de interesse" (Gotlib, 2000, p. 34). E o efeito único, com o passar do tempo, tornou-se um modo principal de se contar uma história curta, cujo ápice está na descoberta do enigma.

Em suas histórias, as casas seculares com escadarias e cubículos estreitos; os velhos sobrados em bairros fétidos, mobiliados com peças antigas impregnadas de histórias, rancores e ressentimentos, são cenários recorrentes. É na intimidade das quatro paredes, no espaço da casa paterna, que encena a tragédia familiar e

\footnotetext{
${ }^{53}$ Um dos primeiros contos do jovem Guimarães Rosa é totalmente espelhado na literatura fantástica. Em 1929, portanto aos 21 anos, Rosa venceu um concurso de contos da revista $O$ Cruzeiro com o texto "O mistério de Highmore Hall”, cuja ação é no interior de um castelo escocês (ver COSTA, C., 2005, p. 76-79).
} 
pequeno-burguesa. Seus livros e contos geram os sentimentos de enclausuramento, dor, dúvida e angústia na convivência familiar neste espaço, quando as subjetividades se opõem e se dilaceram em desejos opostos, como aquela ideia do mar aprisionado entre as rochas. E não foi diferente em suas narrativas fantásticas. Lá estiveram elementos preciosos da obra cardosiana, como as representações de cheiros e sons, além das poderosas descrições das aparências do mundo material, de móveis, paredes, quadros, pequenos objetos e janelas que criam essa atmosfera íntima e particular. Em "A escada" esse retrato das coisas e do ambiente é fundamental:

\begin{abstract}
A luz vinha de um quarto ao fundo, no extremo de um corredor que partia do lugar em que eu estava naquele momento, isto é, uma ampla sala, de teto elevado e mobiliada com móveis severos e antigos. As paredes eram forradas de papel manchado, com desenhos imitando grandes ovais em moldura marrom. Um lustre pendia do alto e seus pingentes de cristal brilhavam conforme os movimentos que eu fazia com a cabeça. Detalhe por detalhe, fui reconhecendo a casa em que habitara outrora, desde as janelas largas, ocultas por pesadas cortinas de veludo grená forrado a ouro, até a cavidade sombria que por detrás de mim ocultava a escada por onde eu subira. Ali, naquele lugar em que eu agora me achava, minha mãe definhara de estranha moléstia. (Cardoso, 2012, p. 112)
\end{abstract}

Nesses dois contos e na fase satânica de sua escrita, a morte é personagem corriqueira, presente entre os vivos e, às vezes, anunciada como a única possibilidade para atenuar a angústia e a solidão. Há contos em que é substituída pela loucura (caso do conto "Simples encontro") ou pelo medo de um deus severo ("O afogado"). Em "Olhos mortos" e "A escada" a morte, no entanto, está no mesmo nível da vida. Em ambos, mortos e vivos contracenam e, aos poucos, vão se assenhoreando da realidade sobrenatural de suas experiências. Em "Olhos mortos", a morte surge paulatinamente. Num dado momento o personagem se descobre morto ao encontrar, entre os convivas, velhos parentes dos álbuns de retrato já mortos. Em “A escada”, a morte leva o personagem principal a revelar, no presente, o passado da casa onde ambos viveram.

\title{
"A escada"
}

Escrito em meados da década de 1940, à mão, como a maior parte de sua produção literária, “A escada” é um dos raros contos cujo manuscrito se encontra 
conservado no Arquivo Museu de Literatura da Casa de Rui Barbosa, onde está o acervo de mais de cinco mil documentos do escritor. Como já dissemos anteriormente, Lúcio Cardoso trabalhava a sua obra a partir de grandes planos de idealização temática. Dificilmente, histórias longas e incomuns na obra do autor, como "A escada" e "Olhos mortos", surgiriam sem um propósito açambarcador de um mundo estético e filosófico próprios e fechado em si, apesar da imensa preguiça, por ele mesmo revelada, de levar adiante seus projetos. Na última página do manuscrito de "A escada" uma anotação, no canto superior, revela a intenção do autor em criar, a partir desses dois textos, uma trilogia que seria completada pelo terceiro conto chamado "O rato branco".

Lúcio anotava suas ideias, principalmente aquelas de obras futuras, nos versos das folhas e cadernos, ou nos cantos das páginas de seus manuscritos. Deixou uma centena de rastros, para nosso deleite. "A escada", como sabemos, foi escrita e publicada, bem como "Olhos mortos", mas não temos notícia de "O rato branco", o que, aliás, revela mais uma faceta do escritor: não completar jamais suas trilogias. A ordem na anotação também não foi seguida ("A escada", "O rato branco" e "Olhos mortos"), uma vez que este último foi publicado um ano antes de "A escada".

Encontramos nestes textos o estranhamento do mundo irreal em conflito com o real; da supressão de tempo, e do inconsciente que nos move aos mais profundos e impalpáveis sentimentos, como o medo, a devoção e o terror. Sentimentos modernos e conflitantes que transbordam nessa longa fase dedicada aos contos, sobretudo nesses de estilo fantástico e que culminam com a segunda fase, a de contos de crime, em que quase todos os personagens encontram a morte.

É no terreno específico da especulação filosófica entre os séculos XVIII e XX que o conto fantástico nasce: seu tema é a relação entre a realidade do mundo que habitamos e conhecemos por meio da percepção e a realidade do mundo do pensamento que mora em nós e nos comanda. (Calvino, 2004, p. 9)

$\mathrm{Na}$ análise, complementa Italo Calvino: "coisas habituais que talvez ocultem sob a aparência mais banal uma segunda natureza, inquietante, misteriosa, aterradora - é a essência da literatura fantástica". Por outro lado, Todorov nos lembra que entre outros critérios da literatura fantástica temos o "acatamento" do inverossímil, pois o "fantástico narrativo" é precisamente uma "perplexidade 
diante de um fato inacreditável, uma hesitação entre uma explicação realista e o acatamento do sobrenatural" (Todorov, 2010, p.39).

Como explicar, no entanto, um autor, brasileiro, fantástico tardio, ${ }^{54}$ católico, homossexual, em nosso momento de pós-Modernismo? A inverossimilhança, desde A luz no subsolo, foi um critério - e um problema para Bandeira e Andrade - quase que permanente em sua obra, com exceção do autobiográfico Dias perdidos. A fase apelidada de satânica tem início com Inácio, um dos personagens mais admirados pelo autor, segundo resposta para a coletânea Dez romancistas falam de seus personagens, de João Condé.

Publicada em 1944, Inácio traz a história de Rogério Palma, um jovem em seus 18, 20 anos, atormentado pelo passado repleto de fantasmas, o pai, a mãe, o amante da mãe. Narrado na primeira pessoa, Rogério relembra o reaparecimento de seu pai, Inácio Palma, cujas lembranças remontavam aos seus quatro anos de idade. Outros fantasmas também reaparecem como o de sua mãe, cujo corpo estava sendo velado. Inácio, seu pai, é um homem decadente, e todo o cenário, entre Botafogo e a Lapa, é de decadência, doença e morte. Na descrição de Carelli:

Inácio enfeitiça Rogério, que não chega a definir se sente por ele atração ou repulsa [...]. É comparado a um demônio, "persegue" Trindade e até aparece em seus sonhos, como também nos de Rogério. Esse "monstro" não envelhece, traço com frequência atribuído a personagens maléficas. "E sempre o vi assim, com essa fisionomia que jamais envelhece, com o mesmo olhar e a mesma cara de boneca". (Carelli, op. cit., p. 129)

Além dos fantasmas, nestas obras está implícita a figura do diabo, tão venerada tanto por Lúcio quanto por Guimarães. E o diabo sempre foi a melhor representação, para Poe, do terror e do medo inconsciente e coletivo da sociedade burguesa-cristã. Em seu Diário completo, Lúcio confessa ter visto o demônio, um sujeito "pequeno, magro e que fala sem parar". 55 Mas em nenhuma passagem comenta ter visto Deus. Para ele, tanto Deus como o Diabo são o mesmo elemento, pois um não "anda" sem o outro. "O diabo nunca anda sem Deus", diz em entrevista a Walmyr Ayala, acrescentando ainda que no romance Crônica da

\footnotetext{
${ }^{54}$ Se comparado com Guimarães Rosa, cujo texto fantástico escrito por ele foi feito e publicado na adolescência, por volta dos 19 anos.

${ }^{55}$ CARDOSO, L. Diário, op.cit., p.112.
} 
casa assassinada é muito possível que a sombra de um se confunda com a do outro. $^{56}$

Nestes dois contos, além das sombras e de todo o mundo sobrenatural, a realidade material existente está fincada nas sólidas construções das casas suburbanas onde as duas histórias se passam. Mais uma vez é o Rio de Janeiro sendo composto pela memória antiga, de mortos náufragos de um tempo já esquecido, já apagado e relembrado apenas pelos fantasmas.

Em "A escada", o fantasma de uma antiga moradora da velha casa surge na vida de um jovem rapaz que também passara parte da sua infância no local. A mulher, já desencarnada, revela um crime.

\begin{abstract}
A lembrança trouxe de um só jato à minha consciência, uma torrente de coisas informes, de sombras e perfumes daquele tempo; como por um processo de magia as janelas surgiram do vácuo, os móveis, os quadros, tudo, e o antigo universo se reconstituiu com uma clareza impressionante. Foi neste momento que a voz, ao meu lado, repetiu num tom singularmente angustiado: "pela escada!" Levantei-me, vesti o capote, tomei o chapéu, ganhando a rua. Comigo mesmo pensava: "é uma velha casa da minha infância, que vou fazer nela?" E achava absurdo que agisse assim, sobretudo porque não tinha sido feliz naquele lugar; era mesmo exclusivamente pela impressão de mal-estar que eu me lembrava dela, e durante grande parte da minha vida consegui esquecê-la como se esquece um fato aborrecido ou uma falta. Agora a velha casa surgia de novo, nitidamente, através do sonho. Caminhando, eu procurava reviver o maior número de detalhes, e me espantava de encontrá-la assim tão nítida, como uma visão preservada pelo ácido do tempo. Não tardou muito, em que ela realmente surgisse palpável aos meus olhos, grande e soturno edifício de pedra, bordado com azulejos portugueses. Olhei-o de longe, com certa emoção, imaginando tudo o que aí eu tinha vivido, meu pobre rosto solitário de criança doente, minhas lágrimas e o vulto carinhoso de minha mãe, desaparecido há tantos anos. (Cardoso, 2012, p. 109) ${ }^{57}$
\end{abstract}

O chamado insistente da voz feminina leva nosso narrador à antiga casa da sua infância, agora um sobrado abandonado, carcomido pelo tempo e pelas lembranças. Neste universo se forma um ambiente de casas e pessoas paradas num tempo, enquanto são conduzidas no presente pelo passado ainda vivo na memória, um passado sempre rico, que se lança num presente consumido por um estado de profunda melancolia. É dessa oscilação que é feita parte da obra dita satânica ou fantástica do escritor mineiro. É dessa negação do presente realista em

\footnotetext{
${ }^{56}$ Entrevista de Lúcio Cardoso a Walmyr Ayala publicada no BBB de maio de 1959, vol. VII, nº 4, p. 172.

${ }^{57}$ CARDOSO, L. Contos da ilha e do continente. Rio de Janeiro: Civilização Brasileira, 2012, p. 109.
} 
prol da imaginação criadora que Lúcio Cardoso sustentou sua narrativa longa ou curta.

\title{
"Olhos mortos"
}

Se a memória - tanto da senhora morta, como do rapaz guiado por ela, é o terreno de especulação dos personagens de "A escada" e o condutor da ação e do desfecho da história, em "Olhos mortos" a memória leva o personagem a compreender seu estado. A partir de camadas e camadas de pequenas descobertas e revelações, o morto entende amiúde sua situação, sem deixar de expressar espanto. E o ápice é quando descobre que seus olhos estão tão baços quanto aqueles das figuras mortas.

\begin{abstract}
É curioso, pensei que não me lembrasse mais desses detalhes, e no entanto eles afluem à minha memória, vivos, como se ainda compusessem a trama da pobre existência que vivi... Sim, a memória não cessa, agora já não dói, mas não cessa. Ainda aqui, sinto a lembrança da vida dilatar-se em mim, como muito tempo depois a gente se lembra de uma queda ou de uma doença da infância. Prosseguindo na minha história, direi que aquelas fotografias, aquelas noites, tudo passou a não me interessar mais. Meus olhos se dilatavam cada vez mais sobre o vazio, e uma força estranha me arrebatava àquele mundo carinhoso. Tudo poderia se ter realizado, nossa vida poderia ter sido outra, se o temor em mim não prosseguisse o seu dissolvente trabalho. Como gestos que repetimos sem que signifiquem mais a antiga dádiva de amor, vivia o meu jogo habitual, mas distante cada vez mais distante. Já não se tratava nem mesmo de uma simples ausência, mas uma assistência irritada, triste e desamparada. ${ }^{58}$
\end{abstract}

A morte não era exclusividade de seu universo literário. Cornélio Penna ( $A$ menina morta) e Octávio de Faria (Mundos mortos) conviviam e elaboraram suas ficções a partir e em torno do tema, ilustrado fartamente com espectros e sombras rondando o mundo dos vivos. Para Teresa Velho, em A morte: uma invariante da obra de Cornélio Penna, "os fantasmas povoam o universo narrativo de Cornélio Penna. E os próprios personagens se apresentam como fantasmas. [...]. Entretanto, a morte é mais especificamente representada pelos fantasmas sem rosto e despertam temor contra a própria morte”, escreve Velho, referindo-se ao personagem Nico Horta, do livro Dois romances de Nico Horta, de 1939 (ver Velho, 1973).

${ }^{58}$ CARDOSO, L., 2012, p. 88-89. 
Lúcio Cardoso, ao contrário, encena a morte não só como uma alusão aos tempos passados ou à reminiscência decadentista, como vemos tanto na obra de Octávio como na de Cornélio, em que o pêndulo do tempo oscila entre a tradição cortejada e um futuro incerto da modernidade. Aqui, a morte é um novo que não se deseja, uma relutância à vida, ou uma opção àquela modernidade proposta. Seus mortos se evadiram pelas asas do fantástico numa clara negação da realidade, embora, em 1959, quando lançou a Crônica, ele próprio se definisse como um escritor que utiliza a realidade para lastrear sua ficção. "Tudo para mim é realidade, se não consigo, se pareço fora da realidade comum dos fatos, é que fracassei” (Ayalla, op. cit, p.172).

A aproximação com os contos fantásticos remete a uma busca pelo metafísico, um mergulho no inconsciente coletivo. Essa entrada oferece ao escritor, e ao leitor, uma oposição ao mundo do realismo de uma década anterior e que ainda ecoava pela literatura brasileira. No mesmo período em que dá início à sua vasta produção de contos, entre 1941 a 1944, é quando redescobre a leitura de Poe e Shelley. Sobre Poe, especificamente, escreve duas defesas intransigentes do escritor e criador, mas que também amparam o homem. Para Lúcio, o escritor foi um exemplo de artista traído pelo seu tempo e meio circundante. Assim, identifica-se com o contista e poeta americano não só pela sua opção filosófica e fantástica, mas também pela incompreensão socioliterária.

Agora falemos claro, falemos logo, sem temor que os "ajuizados" e os "entendidos" venham nos desmentir: o que corrompeu Edgar Poe, o que o matou, como mataria a Byron ou a outro qualquer que naquela época vivesse nos Estados Unidos, foi a mediocridade dos seus contemporâneos, a incompreensão e o desejo de destruir que os burgueses daquela época, como os de agora, aninham no fundo do coração contra tudo o que é belo e subsiste como um desmentido ao veneno das suas almas limitadas. A alma de Poe não podia resistir entre paredes tão estreitas. Não culpemos a bebida, a loucura ou outros fatores quaisquer de terem deformado esta máscara de luz num modelo grotesco, destinada a espantar e a servir de exemplo aos homens bem intencionados. Não culpemos a nenhum destes fatores, que precisamente em homens como Edgar Poe, precisamente nestas grandes máscaras do destino maior, amoldam-se à sua figura como a lepra do tempo aos muros novos. Não é à loucura, não é ao crime, não é à bebida e nem à leviandade, não é a nenhum desses fatores pejorativos com que os homens costumam cobrir aqueles que lhes excedem, que devemos acusar como consequência desta vida miseravelmente falhada. Vejamos primeiro em Edgar Poe, a história de um enorme dom de amor desdenhado, de força desestimada e gênio 
sonegado. Vejamos nele, em primeiro lugar, uma estrela, uma autêntica estrela, ardendo ininterruptamente num céu de lama. ${ }^{59}$

Toda essa descoberta só amplia as possibilidades de a literatura intimista de Lúcio Cardoso ter um diálogo constante com o metafísico. Para Alfredo Bosi,“o melhor conto brasileiro tem procurado atingir também a dimensão metafísica, em certo sentido, atemporal, das realidades vitais: Guimarães Rosa foi mestre na passagem do fato bruto ao fenômeno vivido, da descrição à epifania, a da narrativa plana de imagens e símbolos" (Bosi, op. cit., p. 12).

Guimarães e Lúcio, mineiros, contemporâneos, partilharam do mesmo interesse pelo diabo e suas muitas transformações no espaço simbólico de nossa cultura, bem como pela leitura e admiração por Edgar Allan Poe.

Nos anos 1950, Lúcio Cardoso continua a publicar esporadicamente alguns contos nos jornais paulistas, sem a ênfase do maravilhoso, mas igualmente sombrios e carregados de um ambiente soturno, porém sem os tantos efeitos da literatura fantástica. As suas publicações na imprensa desaparecem em 1951 e ressurgem, quase que diariamente, a partir de 1952, quando assume, em A Noite, a coluna "O crime do dia". A matéria principal: os crimes do cotidiano policial da cidade do Rio de Janeiro. E seus personagens: homens e mulheres da classe média suburbana.

\footnotetext{
${ }^{59}$ CARDOSO, L. A Manhã, 12.7.1944, p. 4, grifos meus.
} 


\section{4 \\ A coluna "O Crime do Dia"}

\section{1}

\section{Lúcio e Nelson: uma moeda, duas caras}

Em grande estilo, Lúcio Cardoso estreia sua coluna de contos de crimes numa quarta-feira, 2 de abril de 1952. O jornal A Noite estampa, dentre suas manchetes da capa, a foto de seu mais novo colunista e o anúncio: "O Crime do Dia". "Lúcio Cardoso, brilhante escritor, um novo companheiro de trabalho", diz a chamada. $\mathrm{Na}$ foto um Lúcio de apenas 23 anos, embora o escritor fosse completar, em agosto daquele ano, seus fatídicos 40 anos. Embaixo da imagem, a notícia propriamente: "Desde hoje conta este vespertino com um novo colaborador, o jovem e brilhante Lúcio Cardoso, laureado pela Fundação Felipe de Oliveira, pelo conjunto de sua obra de poeta, romancista e teatrólogo. Estreando em 1934 com o livro Maleita (conclui na página 12, coluna 3)." $\mathrm{Na}$ conclusão, o jornal apresenta o escritor como um dos "marcantes valores das letras nacionais" resumindo em poucas linhas a coluna a qual se dedicaria:

Entre os episódios que formam a matéria habitual da reportagem policial, Lúcio Cardoso escolherá o que parecer mais sensível ou palpitante, a fim de transpô-lo para o plano literário, amenizando-lhe a crueza da realidade com os delicados matizes da arte do ficcionista e, ao mesmo tempo, do arguto observador da alma humana. ${ }^{60}$

A ideia da coluna era destacar diariamente uma história impactante, recontada a partir de uma narrativa ficcional. O primeiro conto, “Assassínio por engano", traz a tragédia de um homem atormentado pela gravidez repentina da filha. Ao sentir sua honra maculada, ele decide matar aquele que pensa ter traído sua confiança. Compra um revólver e procura o rapaz pelo subúrbio de uma cidade da Baixada e, ao encontrá-lo, dispara os tiros. Entretanto, o rapaz não era o pai da criança.

\footnotetext{
60 "O Crime do Dia: Lúcio Cardoso, brilhante escritor, um novo companheiro de trabalho", $A$ Noite, 2 de abril de 1952, p. 12.
} 
Nas primeiras colunas, os personagens são decalcados do cotidiano da reportagem policial, conforme noticiado, mas com o passar dos meses as histórias ganham autonomia e se afastam do mundo objetivo e dicotômico do crime, dividido basicamente entre a vítima e o agressor. Mesmo assim, a coluna foi feita para um leitor específico, e alguns ingredientes eram indispensáveis, como os crimes passionais, o machismo e os triângulos amorosos que pululam entre os 265 contos criados pelo escritor. Os personagens, quase sempre, pertencem ao mundo urbano e suburbano e, ao contrário dos contos gerais, eles têm profissão, lugar social e transitam entre o desejo de ascender socialmente, a honra, a vingança e a morte. Foram 15 meses consecutivos de coluna, de 2 de abril de 1952 a 24 de julho de 1953, que termina com o título "Alberto".

A coluna foi criada, no entanto, não só para atender ao já raro leitor de $A$ Noite, periódico do quadro de jornais encampados pelo Estado Novo de Vargas na década de 1940. Com os novos tempos e a falta de investimento do governo na imprensa estatal, a administração de A Noite vê seus rendimentos diminuírem, na medida em que o governo Vargas perde prestígio.

Após o suicídio de Getúlio, em agosto de 1954, as novas e sucessivas substituições na administração representaram o golpe final em A Noite. Segundo Carvalho Neto, a inviabilidade do jornal deveu-se também ao fato de ser ele um órgão do governo: "O povo não admite, com toda razão, que o governo seja dono de jornal para ele ler. E deixou de ler A Noite... Jornal do governo é o Diário Oficial". Cerca de dois anos depois da posse de Juscelino Kubitschek, em janeiro de 1956, A Noite saiu de circulação. ${ }^{61}$

No início da década de 1950, A Noite precisava recuperar urgentemente esse prestígio perdido. Mas foi um fator externo o maior responsável pela criação da coluna e, sobretudo, pela busca de Lúcio Cardoso para conduzi-la. Um ano antes, em 1951, surgia um dos projetos mais ambiciosos de jornal popular da capital: o Última Hora, de Samuel Wainer. E, dentre os seus colaboradores, destacava-se Nelson Rodrigues que, sete meses antes do lançamento de "O Crime do Dia", havia estreado no $U H$, em 17 de setembro de 1951, a coluna "Atirem a primeira pedra". A descrição da coluna de Lúcio poderia ser aplicada à coluna de Nelson, que dois meses após sua estreia muda o título para a "A vida como ela é”. O jornal

\footnotetext{
${ }^{61}$ Ver Dicionário Histórico-Biográfico Brasileiro pós-1930, op. cit., vol. IV, p. 4.107.
} 
Última Hora foi fundado para servir de respaldo ao getulismo junto à opinião pública, portanto tinha que nascer como um jornal popular. $\mathrm{O}$ objetivo de Wainer era fazer frente à oligarquia da imprensa brasileira e gerar, por meio do $U H$, um jornalismo popular e independente não politicamente, mas economicamente. $\mathrm{O}$ tiro saiu pela culatra. "Wainer apresentava Getúlio Vargas como 'o poder contra o poder', a contraditória figura política que, embora na presidência da República, empenhava-se em lutar contra "a classe dirigente brasileira" na qual estariam congregados os "verdadeiros elementos do poder". Entretanto, como o próprio Wainer reconheceu, o jornal foi incapaz de atingir as camadas populares.

Mas se o jornal não conseguiu seduzir as classes populares, a coluna de Nelson Rodrigues não só foi um estrondoso sucesso, como ocupou o imaginário da classe média urbana com histórias cheias de paixões e erotismo, com triângulos amorosos, crimes e outras picardias, consagrando o estereótipo suburbano carioca e o Rio de Janeiro como uma cidade muito além do centro de poder que era enquanto capital do país. Nelson já vinha de muitos outros sucessos na imprensa, como o folhetim que assinava como Suzanna Flag, em $O$ Cruzeiro, e peças de teatro. Mas com a coluna foi diferente. "A vida como ela é incendiara a cidade. Era sempre a história de uma adúltera como o próprio Nelson confessava. Ou quase sempre. [...] Na cabeça desses personagens - garantida a virgindade e a fidelidade de suas mulheres e namoradas -, as mulheres e namoradas de outros eram para ser desejadas sem contemplação."

A coluna de Lúcio, no primeiro momento, emulou claramente "A vida como ela é”, mas aos poucos ganha autonomia e uma linguagem própria, apesar de a descrição da coluna de Nelson Rodrigues supracitada se aplicar como uma luva aos ímpetos e desejos dos personagens - principalmente os femininos - de " $\mathrm{O}$ Crime do Dia". Nelson e Lúcio estavam à frente de um mesmo desafio; chegar às classes populares por meio de suas histórias cotidianas reinventadas a partir do desvelo do moralismo latente, do machismo e do conservadorismo social. O fato é que Nelson, jornalista tarimbado, conseguiu com sua linguagem e seu vívido interesse pelo inusitado invadir o imaginário carioca e nacional com as ousadas narrativas da intimidade de seus personagens suburbanos. Tanto que "A vida como ela é" foi publicada por 10 anos, ao contrário da coluna de Lúcio, que um

\footnotetext{
${ }^{62}$ CASTRO, R., O anjo pornográfico - a vida de Nelson Rodrigues, São Paulo: Companhia das Letras, 1992, p. 236-237.
} 
ano e meio depois chegava ao fim. E quais eram as diferenças? Onde Lúcio errou e Nelson acertou?

Nelson e Lúcio nasceram no mesmo ano, em 1912, e construíram trajetórias intelectuais e literárias opostas, porém convergentes. Percorreram, desde muito cedo, as colunas de crime e as mesmas redações de jornais, e não era a primeira vez que se viam disputando o mesmo espaço e o mesmo objeto de desejo. Poderíamos, até, considerá-los avessos complementares; dividiram na vida uma mesma moeda, com duas caras. Se Nelson atacava os "pederastas', Lúcio se assumia homossexual em seu diário, cujo primeiro volume vem a lume em 1960. Se Nelson desejava ser um grande romancista, foi Lúcio quem se tornou o grande escritor. Conservadores em assuntos distintos e igualmente dramáticos, tinham como matéria-prima o subsolo das relações humanas, as ânsias, as lacunas que preenchiam o cotidiano e os temas tabus, tais como incesto e arroubos sexuais de todas as formas, e uma admiração inconteste pelo romancista russo Dostoiévski. Por fim, disputaram, milímetro a milímetro, os palcos dos teatros, tendo Nelson se tornado o maior dramaturgo moderno brasileiro, enquanto Lúcio amargou eternamente o fato de sequer ser considerado um dos primeiros autores do teatro novo. Esquecido, ficou à margem da dramaturgia. Em junho de 1950, Lúcio escreve em seu Diário completo:

Artigo de Tristão de Athayde sobre "Palco". Segundo ele o teatro no Brasil passou a existir depois do movimento pós-modernista. Admiro-me que o Sr. Tristão de Athayde, tendo assistido à representação de peças minhas, conhecendo o meu esforço para levantar o "Teatro de Câmera" e sendo a pessoa que é, omita tão cuidadosamente o meu nome, datando esse esforço novo a partir de Nelson Rodrigues e, finalmente, enumerando pessoas que me aparecem inteiramente destituídas de valor. Ora, O escravo é anterior ao Vestido de noiva. [...] certos silêncios, certas omissões, significam mais do que várias críticas de ataque, se partem de pessoas que aprendemos a admirar desde cedo. ${ }^{63}$

A memória de Lúcio nesse trecho de seu Diário demonstra seu ressentimento com o teatro. O escravo, sua primeira peça, é escrita em 1937, e somente encenada em 1943, ${ }^{64}$ junto com Vestido de Noiva, de Nelson. Ambas são levadas ao palco num esforço teatral do grupo Comediantes, que também surgiu

\footnotetext{
${ }^{63}$ CARDOSO, L. Diários. Organização de RIBEIRO, E. M. Rio de Janeiro: Civilização Brasileira, 2012, p. 277.

${ }^{64}$ CARDOSO, L. Diário completo, op.cit., p.101.
} 
naquele ano. Era a segunda peça de Nelson Rodrigues, que em 1941 havia escrito A mulher sem pecado, e a estreia de Lúcio. Os Comediantes - grupo formado por Santa Rosa (cenógrafo), Ziembinski (diretor e ator), Agostinho Olavo e Brutus Pedreira (atores) - também dava seus primeiros passos naquele ano em que fizeram a façanha de conseguir patrocínio do Mistério da Educação para a montagem de sete peças no Teatro Municipal, duas das quais nacionais e de jovens autores estreantes, Nelson e Lúcio.

Vestido de noiva, um dos maiores sucessos de Nelson Rodrigues, já nasceu bem-sucedida. Meses antes de ir ao palco, Manuel Bandeira, a quem ele confiou o manuscrito da peça, embora o poeta confessasse ser pouco afeito pelo teatro, fez os maiores elogios num artigo de fevereiro de 1943 para A Manhã. "Sem dúvida o teatro desse estreante desnorteia bastante. O que me dana é não ter como ele o dom de dar vida às criaturas da minha imaginação", escreve com entusiasmo. ${ }^{65}$

O escravo, ao contrário de Vestido de noiva, foi um fracasso do qual Lúcio jamais se recuperou. Uma inauguração cheia de erros e, segundo Octávio de Faria, de "muitas pequenas e vergonhosas intrigas". ${ }^{66}$ O próprio Lúcio revela em seu diário as graves discussões com Ziembinski, então recém-chegado ao Brasil. ${ }^{67}$ "Teatro fantasmal, onde os personagens flutuam à luz de círios e falam do fundo de suas covas e de seus impenetráveis tremendos subsolos? Ninguém nega talento do Sr. Lúcio Cardoso, escritor obcecado pela introspecção levada ao delírio, tentando uma arte em profundidade, que não passa, apenas, de uma tentativa", diz o editorial da revista Diretrizes, em dezembro de $1943,{ }^{68}$ então dirigida por Samuel Wainer.

O ressentimento de Lúcio minou toda a sua relação com o teatro e, consequentemente, com Nelson Rodrigues. "A consternante peça de Nelson Rodrigues; durante uma hora uma pobre mocinha deblatera inutilmente para chegar ao ápice de uma inacreditável filosofia: a de que os mortos esfriam depressa", ${ }^{69}$ escreve em agosto de 1951, certamente sobre a Valsa $n^{o}$ 6, que estreara em junho daquele ano. Lúcio considerou Valsa $n^{\circ}$ 6, "execrável”, segundo ele mesmo assume em seu Diário ao relembrar uma conversa com o crítico

\footnotetext{
${ }^{65}$ BANDEIRA, M. "Vestido de noiva", A Manhã, Rio de Janeiro, 6 de fevereiro de 1943, p. 4.

${ }^{66}$ CARELLI, M. Corcel de fogo, op. cit., p. 54.

${ }^{67}$ CARDOSO, L. Diário completo, op.cit., p. 102.

${ }^{68}$ Editorial, revista Diretrizes, Rio de Janeiro, 16 de dezembro de 1943, p. 6

${ }^{69}$ CARDOSO, L. Diário completo, op. cit., p. 377.
} 
Sábato Magaldi. ${ }^{70}$ A vida e a obra de Nelson e Lúcio se cruzam muitas outras vezes e nos surpreendem. Quando Nelson insere personagens mortos e fantasmais em suas peças Senhora dos afogados, de 1948, e Valsa $n^{\circ}$ 6, de 1951, a exemplo de Lúcio em suas novelas satânicas e nos contos fantásticos, recebe do mesmo Manuel Bandeira as críticas sobre a inverossimilhança. ${ }^{71}$ Lúcio foi, em 1947, o primeiro autor de teatro a escrever uma peça, $O$ filho pródigo, para o Teatro Experimental do Negro, de Abdias do Nascimento. Nesta, todos os personagens são negros; Nelson, no mesmo ano, também criou pela primeira vez um protagonista negro para a sua peça Anjo negro, que por racismo e censura social foi interpretado por um branco, Orlando Guy, lambuzado de graxa. Ao contrário, O filho pródigo foi protagonizado por Haroldo Costa, ator negro. Os dois autores abordaram a questão do incesto em suas obras, gerando imensas polêmicas e cisões entre intelectuais, escritores, jornalistas, envolvendo até a Igreja Católica. Nelson insere o tabu na peça Álbum de família, de 1946, e recebe, além da censura estatal, críticas moralistas de todos os jornais e revistas, inclusive de seus pares, sendo salvo pelos textos e opiniões de Ledo Ivo, Rachel de Queiroz, Manuel Bandeira e Nelson Werneck Sodré. O mesmo acontece em 1959, quando Lúcio lança a Crônica da casa assassinada, em que o suposto incesto de Nina e o filho André mobilizou as hostes conservadoras de todo o país. Mas, embora no âmbito das ideias e das ambições literárias e dramatúrgicas Nelson e Lúcio estiveram no mesmo campo, Lúcio jamais conheceu o sucesso como Nelson, e Nelson, por sua vez, jamais teve o reconhecimento intelectual que tanto desejou ${ }^{72}$ durante um período de sua carreira no teatro. Foram como duas faces de uma mesma moeda, divididas por algumas escolhas e crenças pessoais e unidas pela mesma visão conservadora do mundo e pelo mesmo talento em descortinar tantas tragédias humanas num pedaço de papel.

\footnotetext{
${ }^{70}$ Idem, p. 374.

${ }^{71}$ CASTRO, R. O anjo pornográfico, op.cit., p. 213.

${ }^{72}$ Idem, p. 177.
} 


\section{2 \\ 0 crime enquanto vida}

Os resultados de Lúcio no teatro e no cinema foram muito aquém de suas próprias expectativas, e ficou evidente para amigos e críticos que seu talento definitivamente não sabia produzir peças e filmes. $\mathrm{O}$ fracasso arrastou-se por anos em dívidas e mágoas, e a coluna "O Crime do Dia", veio justo num momento em que as contas precisavam ser debeladas e pagas. No memorialista Vida Vida, Maria Helena Cardoso, irmã do escritor e autora, relembra como foi a ida de Lúcio para A Noite, disputar um espaço, mais uma vez, com seu maior concorrente no teatro. Lúcio, no período em que Lelena o escuta e toma notas de suas lembranças, já havia sofrido o AVC, em 1962, que o deixou hemiplégico do lado direito e com graves perdas, jamais recuperadas, na fala e na escrita. ${ }^{73} \mathrm{~A}$ conversa abaixo acontece em 1968, ano de sua morte.

Lembro um domingo que veio Hildon. ${ }^{74}$ Começaram a recordar os velhos tempos de trabalho em A Noite. Hildon pergunta-lhe como foi que entrou para trabalhar naquele jornal, se ele se lembrava. Animou-se e pediu o caderno para escrever: 'Era o ano de 1952 - sem dinheiro, roupas rasgadas e sem o que fazer. Ah, quanta amargura. Foi aí que surgiu Hildon Rocha, que disse que necessitava de um repórter - mas bom.'

'A Noite', perguntei. Topo. Tirou qualquer dúvida e aceitou.

‘Só o Nelson Rodrigues ganha milhões!'

Sorri. Nelson trabalhava no jornal também.

Foi-se embora - no dia seguinte fui apresentado ao Costa Netto. Comecei com um crime na Praia das Bandeiras, Ilha do Governador. Meti mãos à obra e saiu qualquer coisa. Aí aparece um inimigo - dois folhetos lado a lado. Alguém estava brincando comigo. Passei os olhos por toda a redação - não ninguém - Outro conto, depressa antes que o diabo esfregue um olho. ${ }^{75}$

Lúcio nutria grande interesse pelo crime, pela perversão, pela intimidade e atos humanos extremos. Numa conversa telefônica com o jornalista Joel Silveira ${ }^{76}$

\footnotetext{
${ }^{73}$ Para saber mais, ler DAMASCENO, B., Lúcio Cardoso em corpo e escrita, Rio de Janeiro: Eduerj, 2012.

${ }^{74}$ Hildon Rocha, jornalista, foi chefe de reportagem de $A$ Noite, e anos depois, no final da década de 1960, foi censor durante da ditadura militar. Ver KUSHNIR, B., Cães de guarda: jornalistas e censores, do AI-5 à Constituição de 1988, São Paulo: Boitempo Editoral, 2004, p. 176.

${ }^{75}$ CARDOSO, M. H., Vida Vida, Rio de Janeiro: Livraria José Olympio Editora, 1973, p. 348-349.

${ }^{76} \mathrm{Na}$ época editava a revista Veredas do CCBB, e Joel era um de nossos diletos colaboradores.
} 
(1918-2007), entre os anos 2000 e 2001, perguntei como Lúcio tinha chegado à reportagem policial. Joel não titubeou e me disse que Lúcio queria ser repórter policial, pois os crimes eram uma paixão recôndita. Por diversas vezes o escritor pediu a ele, Joel, uma vaga na redação como repórter policial e, segundo o jornalista, foi assim que o escritor surgiu à frente da coluna "O Crime do Dia".

Na leitura de seu Diário completo, principalmente entre os anos de 1949 e 1952, acompanhamos o interesse e os comentários do escritor sobre os acontecimentos policiais na cidade. Não sabemos ao certo em que periódico Lúcio trabalhou como repórter policial e se, de fato, trabalhou. $\mathrm{Na}$ "Cronologia de Lúcio Cardoso (1912-2012)", coligida por Ésio Macedo em Diário completo, ${ }^{77}$ o pesquisador afirma que Lúcio teria ingressado em A Noite no ano de 1947 e iniciado a coluna de crime em 1951. Após nosso levantamento completo das duas colunas de crime e das demais colunas em periódicos assinadas pelo autor, sabemos que a coluna "O Crime do Dia" estreou com grande alarido em abril de 1952, e seu contrato com A Noite estendeu-se até 1957, quando publica a segunda coluna de crime, "Novelinha do dia-a-dia". Em nossa pesquisa não encontramos qualquer incidência do trabalho jornalístico de Lúcio Cardoso na reportagem policial em A Noite nos anos de 1947, e, segundo a memória de sua irmã, o escritor teria iniciado suas atividades no jornal somente em 1952. De acordo com Ruy Castro, na biografia $O$ anjo pornográfico, entre 1946 e 1947 Lúcio teria ocupado o lugar de Nelson na direção da revista Detetive, publicação dos Diários Associados, ${ }^{78}$ enquanto Nelson se encarregaria de um novo posto em $O$ Cruzeiro, também do grupo.

A revista Detetive era uma publicação mensal de contos de suspense e crime, bastante popular, com capas chamativas e cerca de cem páginas com histórias de Agatha Christie, Georges Simenon, Somerset Maugham, Conan Doyle e outros. É bom lembrar que, anos antes, Lúcio havia traduzido Drácula, de Bram Stoker, ${ }^{79}$ para as edições O Cruzeiro ${ }^{80}$ e participado, também, da coletânea Antologia de carnaval, de 1945, da mesma editora, que, por sua vez, devido à

\footnotetext{
${ }^{77}$ CARDOSO, L., Diários, op. cit., p. 25.

${ }^{78}$ CASTRO, R., O anjo pornográfico, op. cit., p. 183.

${ }^{79}$ STOKER, B. Drácula: O homem da noite. [Por: Lúcio Cardoso]. Rio de Janeiro: O Cruzeiro, 1943. (Drácula). Horror.

${ }^{80}$ As edições O Cruzeiro, um departamento da revista homônima, surgiu em 1943. A revista, na época, era a maior publicação ilustrada brasileira e latino-americana.
} 
grande concorrência entre os impressos na época, não publicaria um autor de grupo concorrente.

A partir dessas referências, presumimos que o escritor fosse, no período, ligado ao grupo dos Diários Associados. Em 16 de fevereiro de 1950 escreve em seu diário ter se desligado do jornal onde trabalhava: "Abandono finalmente o jornal onde vinha trabalhando [...]. Não posso dizer que tenha me adaptado à folha onde trabalhei - ao contrário, em poucos lugares me senti tão infeliz, tão deslocado, e tão humilhado no cerne mesmo da minha condição de escritor". ${ }^{81}$

Durante os anos de 1949 a 1951, quando dá início à escrita em seu diário, percebemos a forma interessada e crítica com a qual acompanhava os crimes mais noticiados nos periódicos cariocas. Os crimes, entretanto, que mais chamam a atenção do escritor têm alguma conotação sexual e religiosa. Os casos de estrangulamento de homens mais velhos, por jovens, no centro do Rio, na Praça da República e em Niterói, faz com que dedique algumas páginas em 1949. "São jovens sem nenhum escrúpulo [...] produtos de uma falsa civilização exterior e vertiginosa que se alastra pelo Brasil". ${ }^{82}$ O segundo crime, semelhante ao da Praça da República, também é anotado pelo escritor:

Outro crime em Niterói, quase absolutamente idêntico ao da Praça da República. Reaparecimento dos mesmos tipos, isto é, os jovens sem escrúpulos. E neste, como naquele, a presença também de um velho sem escrúpulos, que atrai o crime como sob o impulso de uma força secreta. [...] nas paredes manchadas de sangue e de um quarto suspeito, o que se inscreve é um esquema traçado há muito: o húmus quente que borbulha da vida sacrificada, é apenas o clímax de uma diabólica predestinação levada a termo. ${ }^{83}$

No ano seguinte, uma leva de novos crimes chama a sua atenção, dentre eles o linchamento de uma mulher em Muriaé, interior de Minas Gerais, por fanáticos religiosos guiados por um jovem líder conhecido como "Anjo". "Um clima de Dostoiévski - como em geral o crime tocando de perto problemas fundamentais da essência humana, lembra sempre algumas verdades apontadas pelo romancista russo. [...] Alguns fanáticos, guiados por um jovem que se intitulava 'Anjo' assassinaram uma pobre mulher que consideravam possessa", ${ }^{84}$ observa. Nesse

\footnotetext{
${ }^{81}$ CARDOSO, L., Diário completo, op. cit., p. 150.

${ }^{82}$ Idem, p. 36.

${ }^{83}$ Sobre os crimes na Praça da República e em Niterói, ver o Anexo Crimes.

${ }^{84}$ CARDOSO, L. Diário completo, op. cit, p. 67.
} 
mesmo ano, revela a convivência com o bandido Telmo de Araújo, que conheceu num carnaval. Apelidado de T., no Diário, Lúcio relembra a noite em que passaram juntos no "barracão" do jovem. Telmo, naquele ano de 1949, surgiu nas páginas dos jornais por ter fugido da penitenciária. ${ }^{85}$

T. possui 18 anos, tez pálida, cabelos muito pretos, olhos intensamente azuis. Olhos que vivem nesta face com a melodia agreste dos felinos. Quando conheci, surpreendeu-me a força que manifestava, calada e secreta. Fugiu de casa, agrediu algumas pessoas, roubou perto de trezentos mil cruzeiros, foi condenado e eu o revi mais tarde na penitenciária, numa visita que fiz àquela casa. (Lembrei-me particularmente de um dia de carnaval, quando me levou à casa onde morava, um sórdido barracão, em companhia de um preto que ele espancava continuamente. Embriagou nesta noite e quebrou todos os móveis que existiam lá dentro. Eu o contemplava cheio de admiração) ${ }^{86}$

Em artigo sobre Crônica da casa assassinada, ${ }^{87}$ Evando Nascimento levanta uma importante questão para análise desse grande material: o crime na obra do autor e o valor da verdade. "Para entender o valor de verdade que o signo do crime articula, é preciso consultar o Diário do escritor. Lá, o crime é, antes de tudo, um tema literário a ser interpretado em seus diversos motivos. Os crimes narrados têm como referência maior a literatura de Dostoiévski, [...] Lúcio faz observações a partir de um crime praticado em Muriaé, a respeito do qual a condição criminosa é apresentada nos limites entre a liberdade e a loucura humana; a loucura como o grau máximo, absoluto de liberdade, quem sabe indesejado", 88 analisa o pesquisador, para quem no Diário do escritor o crime surge também como um mal a ser evitado e como um simples vestígio da bestialização do homem.

A convivência com o crime, as citações recorrentes ao mundo ficcional de Dostoiévski e clara literariedade da experiência real, bem como sua admiração pela violência e beleza conjugadas, pelo submundo da Lapa e de outras áreas centrais da cidade, fazem de Lúcio um observador mais do que peculiar do Rio de Janeiro. Como repetia, o Rio estava entranhado em suas veias, não tinha como

\footnotetext{
${ }^{85}$ Sobre a fuga de Telmo Araújo, o T., e Carne Seca, ver o Anexo Crimes.

${ }^{86}$ CARDOSO, L. Diário completo, op. cit, p. 75-76.

${ }^{87}$ NASCIMENTO, E., “Crônica de um crime anunciado”, Ipotesi, Revista de Estudos Literários, Juiz de Fora, v. 5, n. 1, p. 49-64, janeiro-junho 2001.

${ }^{88}$ Idem, p. 59.
} 
fugir. ${ }^{89}$ Em mais de uma vez cita visitas à penitenciária, como na fuga de Telmo e do famoso "Demônio Louro", o hábil bandido Carne Seca, homem de olhos verdes, em cujas costas havia um São Sebastião tatuado e, no peito, um coração superposto por uma cruz tendo ao lado duas cabeças femininas, além dos nomes de suas irmãs e da mulher marcados nos braços direito e esquerdo, ${ }^{90}$ inteligente e expressivo. Foi apresentado pelo diretor da penitenciária, o advogado Francisco de Assis Barbosa.

Durante alguns minutos dei vazão a uma curiosidade sem limites. Carne Seca pareceu-me antes um menino assustado, cheio de tatuagens, ignorante e simples. De vez em quando fita-nos com magníficos olhos verdes. [...] Nada que me lembre ferocidade ou esse ar machucado de certos criminosos. Apenas confusão, falsa noção de bravura - ou autêntica, que sei eu. ${ }^{91}$

Ao passo que nutria esse fascínio pelos criminosos e pelo mundo do crime, se ressente de trabalhar na imprensa: "Nada existe de mais atroz para o escritor do que a necessidade de ganhar o seu sustento com as próprias mãos. É uma dupla condenação ao cativeiro", escreve. Mas é da já longa experiência literária, 18 anos desde o lançamento de Maleita, e do mergulho profundo na alma do Rio de Janeiro e no drama, além de sua própria condição de homossexual, que surge a coluna "O Crime do Dia", com uma gritante diferença do material escrito por Nelson Rodrigues, pois em “A vida como ela é” temos pequenas histórias, às vezes crônicas, outras não. Mas em "O Crime do Dia" temos contos longos que trazem a marca de um escritor à frente da história, e não e tão somente seduzido por ela.

Em várias ocasiões, Lúcio foi obrigado, para sobreviver, a fazer mais ou menos jornalismo literário. Essa obrigação era então o quinhão da maioria dos escritores brasileiros. Mas aparentemente essa atividade tão próxima da criação literária, em particular o caso da crônica, era considerado por Lúcio um verdadeiro inimigo.

Levado a escrever para os jornais, escolheu publicar contos, de preferência crônicas e críticas, bem pouco numerosas em sua produção. Quando se sacrifica a esse gênero literário, mostra-se com frequência polêmico e mordaz, dando amplo espaço ao sonho.

Certo dia confiou sua intenção de publicar uma coletânea de contos que levaria o título "As histórias ditadas durante o sono". Este é revelador ao mesmo tempo do

\footnotetext{
${ }^{89}$ CARDOSO, L., Diário completo, op.cit., p. 140-141.

${ }^{90}$ S/A, A Manhã, Rio de Janeiro, 10 de junho de 1950, p. 13.

${ }^{91}$ CARDOSO, L., Diário completo, op. cit., p. 91.
} 
caráter espontâneo da escrita quase automática (escrevia esses textos diretamente à máquina e esse primeiro jato, apenas relido, era impresso pelos jornais), do lado voluntariamente onírico e da inspiração escabrosa de suas histórias. Enfim, o título lembra que o autor não se jogou muito nesses textos de circunstâncias. Com grande facilidade para escrever, realiza-se melhor em alguns "contos cruéis", curtas histórias que nos provam sua predileção pela narrativa. ${ }^{92}$

O pesquisador Mário Carelli acrescenta, ainda, que os contos de crime da década de 1950 foram realizados a partir de fatos reais selecionados do noticiário. "Nessas páginas encontra o tom dos diálogos dos subúrbios cariocas com suas costureiras, suas prostitutas, seus marinheiros, seus velhos libidinosos e suas viúvas sem dinheiro. Lúcio respeitou as características do gênero, concentrando a narração em um episódio cuja tensão conflitual se resolveu no tempo da narrativa", diz Carelli, acrescentando que nestes contos, mais até que nos "literários", o escritor se compraz em pinçar os crimes mais interessantes, dando predileção pelas perversões e loucura. De fato, o autor vivia os crimes e sonhava abundantemente com eles.

Sonho quase todas as noites, e sonhos de uma tal tristeza que acordo transido e sem coragem para me mover da cama. São cenas de um destino amargo e truncado, crimes que vejo cometer, com uma arma em riste e o sangue golfando vivo e violento, momento de tragédia em que todo ser recua alvoroçado, instantes de outra ansiedade. $^{93}$

A ideia da perversão, do crime como um sonho, e da tênue separação entre realidade e literatura, vida e obra, alinhavou toda a sua literatura, levando esse mesmo fio condutor à Crônica da casa assassinada. Tanto faz se a corrupção da moral se dê por um assassinato ou por uma questão sexual, o fato é que as subversões de alguns valores agregados à vida cotidiana dão ao homem e mulher cardosianos esse sentido amoral, acima do bem e do mal, de Deus e do Diabo. Nestes contos de crime, ele se entregou de corpo e alma à matéria crua, sem metáfora ou alegoria, indo sempre na contramão da moral estabelecida. "Desde jovem, gostava do romance policial e como foi abundante sua produção de histórias de crime", lembra Carelli, ${ }^{94}$ que atribui o "retalhamento da narrativa de Crônica da casa assassinada a elementos da "intriga policial". De fato, na

\footnotetext{
${ }^{92}$ CARELLI, M., Corcel de fogo, op. cit., p. 115.

${ }^{93}$ CARDOSO, L., Diário completo, op.cit., p.67.

${ }^{94}$ CARELLI, M., Corcel de fogo, op. cit.
} 
Crônica, temos esse forte vínculo com o romance policial, o que não acontece nos contos de crime, cuja narrativa é voltada exclusivamente à revelação do crime a partir das relações humanas. Não importa muito o suspense, as camadas de descobertas ou os enredos paralelos. Nestes contos, bem como nos fantásticos e nas novelas satânicas, é a revelação das subversões humanas, seus crimes e motivos íntimos o que mais sobressai ao longo da narrativa.

Nos contos da coluna "O Crime do Dia" o tempo da narrativa é condizente com o tempo de uma coluna quase diária. Nesse sentido, temos aí dois tempos: o diário, em que a partir do presente o autor escreve sua história, e, neste caso, o tempo do fazer se assemelha ao tempo da crônica. Mas, por outro lado, o tempo da narrativa em si é atemporal, pertence ao tempo da literatura e, portanto, mais uma vez os textos voltam a se aproximar do conto, pois a princípio não têm nenhuma relação obrigatória com o presente ou com o tempo das histórias reais. São histórias longas, quase diárias, de cerca de oito mil caracteres, algo em torno de quatro laudas por texto, o que torna o empreendimento ainda mais memorável.

\section{3 É conto? É crônica?}

No artigo "A vida ao rés do chão", Antonio Candido salienta, logo no primeiro parágrafo, que é inimaginável um autor especialista em crônicas receber o Prêmio Nobel de Literatura. Para o crítico literário, a transitoriedade da crônica e sua aproximação com o cotidiano jornalístico coloca-a em outro patamar, quase como uma literatura de segunda classe.

Por se abrigar neste veículo transitório, o seu intuito não é o dos escritores que pensam em "ficar" isto é, permanecer na lembrança e na admiração da posteridade; e a sua perspectiva não é a dos que escrevem do alto da montanha, mas do simples rés do chão. ${ }^{95}$

Mas, entre nós, a crônica fez escola e revelou grandes autores, sobretudo entre os anos 1940 e 1960. No ambiente lítero-jornalístico vivido por Lúcio e por seus contemporâneos, a crônica surgia no espaço do jornal, da reportagem policial e disputava com o conto um lugar de destaque. Ao contrário do conto, a crônica

${ }^{95}$ CANDIDO, A., Para gostar de ler: crônicas, vol. 5, São Paulo: Ática, 1981. 
está embebida daquele caráter de urgência, de uma "impaciência que exige alimentação diária", na concepção de Sergei Tretiakov, ${ }^{96}$ sendo que por aqui é uma narrativa cheia de humor, com graça, leveza e alguma tristeza, como podemos constatar nas crônicas de Rubem Braga, Cecília Meireles, Carlos Drummond de Andrade, Fernando Sabino, dentre muitos outros que desceram ao rés do chão. Lúcio não fez crônica de crime, mas escreveu com graça e pouca leveza as suas histórias urbanas.

Em seu diário, nos falou sobre crimes sonhados envolvendo episódios cruéis de uma narrativa sem história contínua, desencadeadas por imagens que o remetem ora à infância, ora à sua condição de escritor, ora à literatura, ora ao cinema. Como abordamos anteriormente, diversos critérios apontados por Candido, em sua análise sobre a crônica, sugeririam que os textos de Lúcio, na coluna "O Crime do Dia”, fossem mais próximos da crônica do que do conto. Mas a dificuldade do escritor com o tempo da crônica e com sua efemeridade está no cerne de sua compreensão literária global. O controle que exerceu na feitura de seus personagens, seus atos, e suas aparições em cena, era uma forma de manter sob seu domínio uma coerência estilística e conceitual. Até suas sombras passavam por um estudo prévio e designavam perfeitamente um significado, projetando suas ações para além do gesto e da presença humana, dando à sua obra literária os psiquismos de que tanto se falou. Não estava no seu plano, definitivamente, descer ao rés do chão.

$\mathrm{Na}$ coluna do jornal não havia tempo e espaço para aprofundamentos, e, a princípio, os personagens foram decalcados da realidade. Isso levou o escritor a transformar a matéria jornalística cotidiana, com seus dramas mesquinhos e infelizes, em uma história que tem como fundo a tragédia dos tempos modernos, nos quais os valores sociais e morais de um século anterior são esgarçados e, em seu lugar, é encenada uma nova realidade. Nesse cenário, o corpo morto ou fracassado, protagoniza a nova moral. A partir dessas mortes, aniquilamentos suaves e quase despretensiosos, sem efeitos espetaculares ou ruídos maiores, o escritor representa poeticamente o crime, que pode ser o suicídio, o assassinato ou o crime sexual.

\footnotetext{
${ }^{96}$ BENJAMIN, W., op.cit., p. 124.
} 
Pela primeira vez, abriu mão de seus devaneios e planos literários extremamente organizados e repensados, muitos dos quais baseados em parábolas bíblicas, sequências quase fílmicas em que personagens, ações inteiras, ambientes, lutas e até mesmo sombras são estudadas, enumeradas e elaboradas em seus mínimos detalhes, como é possível conferir nas tantas anotações deixadas em seus cadernos arquivados na Fundação Casa de Rui Barbosa. ${ }^{97} \mathrm{Na}$ coluna, as histórias vêm num só jato, direto da máquina de escrever para o clichê do jornal. Não passa pela escrita manual e ganha, com isso, um discurso objetivo, urgente, sem as tantas nuances e sombras típicas de sua narrativa. Entretanto, não atribuímos a esses textos o título de "crônica", pois, como lembra Bosi, muitos contos se assemelham a crônicas. Lúcio realizou nesse período contos para um espaço de crônica. E nisso sua coluna também se assemelha com a "A vida como ela é”, pois estamos diante de dois grandes contadores de histórias, observadores incontestes da alma das ruas.

\section{4}

\section{Os 265 crimes de quase todo dia}

Há um período muito pouco conhecido, mas de grande importância, na vida de Lúcio Cardoso, constituída pela sua atividade jornalística. Durante algum tempo, com aquela generosidade que lhe era característica, dedicou-se o romancista, quase por inteiro, ao registro dos dramas da cidade, através das colunas de tradicional vespertino [...]. Fixava ele, em crônicas marcadas pela pungência, episódios dolorosos e sombrios, que tinham como personagens deserdadas criaturas dos submundos, cujas realidades o cronista descrevia cruamente.

Lúcio Cardoso não se afastava, nessas crônicas diárias, de certo clima de seus livros maiores [...]. Misturavam-se, na prosa com que enchia duas compactas colunas de A Noite, realismo e poesia, predominando os casos de paixão desatinada, pelos quais experimentava enorme fascínio. Levou, para atividade jornalística, as vivências das noites passadas em claro, em contato com toda uma fauna madrugadora, que ele costumava ouvir de coração aberto. ${ }^{98}$

O jornalista Raymundo Souza Dantas foi o único contemporâneo de Lúcio, dos tempos de A Noite, a relembrar as colunas de crime que o escritor produziu naqueles anos de 1952 e 1953, sendo este o registro que temos sobre o período em

\footnotetext{
${ }^{97}$ Ver em especial as anotações do romance incompleto "O riso escuro ou o pavão de luto", LC31, PI-279, no Arquivo Lúcio Cardoso, AMLB, Fundação Casa de Rui Barbosa.

${ }^{98}$ SOUZA DANTAS, R. "Lúcio Cardoso, jornalista", Jornal do Brasil, s/d, Arquivo Maria Helena Cardoso, Arquivo Museu Literatura Brasileira, Fundação Casa de Rui Barbosa.
} 
que escreveu quase diariamente sobre a cidade e seus crimes. Dantas era repórter de política, e num texto nostálgico, do final da década de 1960, lembra do dia a dia no jornal, da relação conflituosa de Lúcio com os jornais e da sua duplicidade e dubiedades marcantes, afinal era um escritor e não um repórter quem estava por trás da narrativa dos crimes e seus personagens. Tanto assim que o próprio jornalista, no texto acima, não consegue precisar as crônicas poéticas realizadas pelo autor:

Era um raro em nosso ambiente, quer pelo comportamento, quer pelo ideário. Num dilaceramento constante, dividia-se entre os seus dramas e os dramas das miseráveis vítimas de uma engrenagem que ele denunciava a seu modo, em nome de valores que defendia com afinco, incorruptível. ${ }^{99}$

Nas páginas de A Noite, Lúcio dava vida ou a renovava, a partir de seu próprio enredo ficcional. As histórias de mulheres e homens sem qualidades e, contraditoriamente, homens e mulheres cheios de qualidades foram contadas em 265 contos, nos quais diversos crimes, fossem latrocínios, homicídios, traição, suicídio, crimes por acaso, por erro, por pressa, crimes cometidos por indivíduos suburbanos, mas, sobretudo, urbanos, e que pertenciam a essa nova configuração da cidade inaugurada a partir da década de 1950. Os papéis sociais ainda eram marcados pelas fortes diferenças de gênero, pelo machismo, pela ênfase dada à virgindade e à divisão do trabalho.

\begin{abstract}
Descia fundo nesse cotidiano dramático, buscando as raízes humanas de muito daqueles casos que a reportagem não chegava a alcançar, ou de que não fazia conta, desprezando-a pelo lado sensacionalista ou brutal do acontecido. Através do tratamento superior que lhes dava, projetava-os com uma luz diferente, focando o lado da sombra de episódios que, à primeira vista, não pareciam merecer além do simples registro policial. ${ }^{100}$
\end{abstract}

Nos contos desse período, Lúcio faz um recorte muito especial da cidade e seus habitantes. Uma nova onda comportamental varria, sobretudo, a pequena classe média suburbana que espelhava suas ações nas classes mais abastadas, na leitura das revistas ilustradas e alimentava um sonho de consumismo visto pela primeira vez no país. Aproveitando-se de sua arguta observação, deu a esses

\footnotetext{
${ }^{99}$ Idem.

${ }^{100}$ Idem.
} 
personagens mais do que a simples transposição da realidade para a ficção. Centrou a maior parte de suas histórias nas relações entre homens e mulheres e, sobretudo nas paixões desencadeadas pelos triângulos amorosos, matéria que sempre, moveu o romancista, como escreveu em 1944 no calor de uma polêmica sobre um concurso literário em que o autor deveria escrever um romance sem beijos, sem amor e muito menos paixão, ao que Lúcio, com seu humor ácido escreve: "Ao longo de suas existências todos os grandes escritores, desde Shakespeare, Stendhal, Tolstoi etc., afirmaram inequivocadamente que o domínio do romancista é o das paixões, estas tristes paixões, pelas quais se enlouquece". ${ }^{101}$ As grandes paixões proibidas, o sexo e a descoberta estão entre os temas prediletos do autor nos contos de crime. Para Ruy Castro, em sua biografia de Nelson Rodrigues, o sexo e a culpa formavam o espírito revolucionário da época. “As moças tinham vontade própria e também desejavam os homens que não deviam desejar. E com isso, todos eles, homens e mulheres, viviam num estado de permanente excitação erótica", escreve. ${ }^{102}$ Certamente essa era a realidade dos personagens de "A vida como ela é", mas em "O Crime do Dia" a traição redundava em morte e o erotismo era condenado com a vida. A culpa católica de Lúcio estava em alerta.

\section{Literatura e documento}

Nem sempre a literatura pode ser considerada um documento válido para analisar a história. O narrador-cronista de Benjamin tem o dom de contar a história, mas é facultado ao historiador explicá-la, pois, segundo o filósofo, não podemos nos contentar em representar os acontecimentos como modelo da história do mundo, ${ }^{103}$ como o faz o cronista. Roberto Schwarz, por sua vez, observa na introdução de Os pobres na literatura brasileira que

O contra-senso de usar a ficção como documento bruto se desprestigiou. Entretanto, nem por isso a questão da realidade deixou de existir, e se de fato a insistência na forma, na primazia da organização sobre elementos de conteúdo serviu para distinguir a linguagem artística das demais, ela também permite o

\footnotetext{
${ }^{101}$ CARDOSO, L., "Romance do ódio", A Manhã, Rio de Janeiro, 23 de maio de 1944, p. 4.

102 CASTRO, R., O anjo pornográfico, op.cit., p. 237.

${ }^{103}$ BENJAMIN, W., op.cit., p. 209.
} 
confronto e algo como uma competição entre as linguagens, devolvendo à literatura a dimensão de conhecimento que ela evidentemente tem. ${ }^{104}$

Por meio desses contos vemos um amplo quadro sobre o período, em que as mudanças culturais e sociais do pós-guerra chegam paulatinamente. As mulheres de Lúcio queriam um emprego e um marido, joias no dedo e um amante rico (“Um retrato", 24/04/52). E os homens também. (“As duas irmãs", 19/05/52). Tanto na coluna de Nelson como na de Lúcio, as mulheres ganham especial destaque dentre os personagens: trabalhadoras, na sua maioria, elas são as primeiras a serem chamadas às mudanças de comportamento. Não é raro encontrar na coluna um conto sobre uma mulher que foge de casa com o amante e o abandona por um emprego. O trabalho é citado na maioria dos contos, e até valorizado. Menos raro ainda é a história de jovens homossexuais martirizadas por freiras (“Orfanato", 26/09/52), ou jovens suicidas martirizadas igualmente pela opressiva vida dos orfanatos católicos ("Orfanato", 13/05/1953). Apesar de mostrar a mulher frequentemente como agente dessas mudanças, os contos são invariavelmente misóginos e apresentam essa mulher, ao mesmo tempo, interesseira, subalterna e invariavelmente com seu corpo sexualizado. São prostitutas, traidoras, sedutoras e, como Nina, de Crônica, incestuosas. O traço misógino do escritor, revelado no Diários revisto em 2012, no qual os trechos suprimidos na edição de Octávio de Faria, na década de 1970, foram recuperados, ganha novos indícios no dia a dia da redação. Diz Lúcio sobre as mulheres: "O homem - o macho - é muito mais capaz de genialidade que a mulher; é mais orgulhoso, mais centro da Criação, mais enredo do destino - uma interrogação viva e apaixonadamente escandalosa. [...] O sofrimento talvez seja a grandeza peculiar da mulher e, por muito sofredora que seja a raça dos gênios machos, esta nunca atinge o padecimento humilde e apagado da mulher [...]". ${ }^{105}$

Lúcio colocou nesses contos de urgência uma série de questões que jamais pensaria em abordar em seus contos gerais, primeiro porque estava em contato com as notícias policiais do jornal, em que a vida humana é narrada a partir da espetacularização do sofrimento, da perda e do vácuo do indivíduo. Segundo, porque era imperioso produzir diariamente uma média de 8 mil caracteres por dia.

\footnotetext{
${ }^{104}$ SCHWARZ, R., Os pobres na literatura brasileira, São Paulo: Editora Brasiliense, 1983, p.7. As palavras foram marcadas em itálico pelo autor.

${ }^{105}$ CARDOSO, L., Diários, op.cit., p. 140.
} 
Um conto por dia, com início, meio e fim, enredo completo e, claro, o efeito único, a epifania, que faz uma história banal se tornar uma narrativa memorável e digna de ser lembrada e eternizada em livro, ao contrário do que Candido apregoa sobre a relação dos escritores-cronistas com a efemeridade do texto jornalístico. O que Lúcio, sem dúvida, corroboraria.

\section{5 \\ A gênese da coluna "O Crime do Dia"}

"O Crime do Dia" só ganhou esse nome no primeiro texto, publicado em 2 de abril de 1952, e no anúncio da primeira página que dava as boas-vindas ao escritor. Manchete na primeira página, a coluna foi chamada logo em seguida de seção e, até o final em 1953, ficou sob o guarda-chuva de outra seção, ainda maior, intitulada "Risos e Lágrimas da Cidade". Nesta, temos um grande painel do crime na cidade. Em pequenos textos é noticiada uma gama de acontecimentos não só no Rio de Janeiro, mas também em cidades fluminenses e outros locais do país. O importante é a relevância do crime. Os suicídios têm grande destaque, sendo 2 a 3 anunciados por dia; os crimes de latrocínios, sobretudo aqueles envolvendo personagens conhecidos do dia a dia da cidade, como o Carne Seca e o Carne Crua, também ganham espaços maiores. A linguagem é prosaica, ingênua e a escrita é livre, sem a organização do texto jornalístico que conhecemos hoje, pois havia um apelo ficcional até nas reportagens em que a descrição dos lugares, dos bandidos e do crime atendia a outra necessidade, como a da narrativa, além da informação simples e bruta.

O jornal A Noite era um diário popular, de 16 páginas, voltado para a pequena burguesia. Diariamente mais de uma notícia sobre crime era publicada em sua primeira página. Títulos como "Já pescou 22 cadáveres na Guanabara", “Assassínio da Lua Cheia: Tirou fotografias antes de estrangular a jovem”, sobre crime na Inglaterra ou, ainda, "Morena, elegante e linda: Prisão do marido da terceira mulher", sobre o famoso crime da Ladeira da Sacopã, em abril de 1952, eram frequentes. $\mathrm{O}$ assunto crime ocupava pelo menos duas páginas, a de $\mathrm{n}^{\mathrm{o}} 2$ e a 12, onde ficava a coluna de Lúcio. Mas algumas notícias sobre crime eram publicadas mesmo em páginas não dedicadas ao assunto. $\mathrm{O}$ jornal se dividia em 
temas comuns a quase todos os impressos dos anos 1950: política, política externa, cidade, entretenimento/cultura, sociedade e esporte.

Os contos de Lúcio ocuparam, primeiro, a parte central da página, logo abaixo do título da seção. Seu nome era exibido, em destaque, em letras capitulares em branco sobre uma plaquete de fundo preto, abaixo ou ao lado do título do conto. Uma coluna diária, até se firmar, passa por várias mudanças gráficas. Mas de meados de 1952 até o final da coluna, em julho de 1953, esteve no mesmo lugar, deixando o centro da página para ocupar toda a lateral esquerda, com um detalhe: um fio a separava totalmente da seção "Risos e Lágrimas da Cidade", criando assim uma independência antes não observada. Lúcio escreveu no período um conto quase diário e apenas seu nome, naquela página, tinha tamanho destaque. Nos primeiros dias, as histórias eram decalcadas totalmente das reportagens. "Assassínio por um dia", o primeiro conto, traz a história do pai que mata um jovem por engano, pressupondo ser ele o homem que engravidou a filha. A história, real, foi reportagem destacada na primeira página do jornal. O título da matéria era "Fez do pai o assassino".

\begin{abstract}
Uma jovem de apenas 18 anos, pelo seu procedimento leviano, foi a causadora da tragédia, que transformou seu velho pai num criminoso. [...] Tudo se iniciou com um romance entre Alfredo Calixto Ferreira da Silva, de 19 anos, solteiro soldado da Cia de Guardas da Aeronáutica, residente com seus velhos pais [...]. O rapaz conhecera há cerca de um ano a jovem Lourdes, filha de Leotário José dos Santos, [...] na localidade de Moquetá.

[...]

Alfredo já esquecera completamente a jovem, quando ocorre um fato que deixou o rapaz bastante contrariado. É que Lourdes se engravidara e jogara-lhe a culpa do sucedido. ${ }^{106}$
\end{abstract}

Como observou seu colega de redação, Lúcio não se afastou "do clima de sua obra de ficção" para criar suas histórias a partir do registro jornalístico. Aproveitando o enredo e os fatos, o escritor "revelou situações que jamais seriam matéria de um texto jornalístico"107, e muitas vezes as situações que enredava sequer faziam parte das informações do texto original, isto é, da história real.

\footnotetext{
${ }^{106}$ CARDOSO, L., “Assassínio por engano”, A Noite, seção Risos e Lágrimas da Cidade, O Crime do Dia, Rio de Janeiro, quarta-feira, 2 de abril de 1952, p. 12.

${ }^{107}$ SOUZA DANTAS, R., "Lúcio Cardoso, jornalista", op. cit.
} 
Tudo começou numa festa simples, no terreiro, onde trocavam os primeiros olhares. Ela se chamava Maria de Lourdes, e ele, Alfredo Calixto da Silva. As palavras iniciais foram ditas junto à fogueira, enquanto as batatas chiavam sob as brasas.

- Onde você mora?

E ela, toda sorrisos para o novo namorado:

- Em Muquetá.

Muquetá ficava em Nova Iguaçu, onde morava o pai da moça, Leotário José dos Santos. Alfredo passou a ir lá todas as noites, mantendo longas conversas com a namorada, junto à cerca que vedava a casa. No entanto, não tinha a menor intenção de levar as coisas muito além. Maria de Lourdes era sensivelmente mais velha do que ele.

- Você não quer casar comigo? - perguntava ela fazendo-se faceira. E ele, fugindo ao assunto, com os olhos longe:

- Quero sim. Mas um dia desses... Tem tempo.

$[\ldots]$

Durante dias seguidos Leotário passou pelas ruas de Nova Iguaçu, e ontem à noite, afinal, deparou com o "gambá" a uma esquina, conversando com outra moça. Não teve dúvidas apontou a arma e disparou. Alfredo caiu mortalmente ferido por um tiro no abdômen.

*

No Hospital, os médicos fizeram todo o possível. O rapaz, porém, falava nos últimos instantes. Ele próprio compreendeu tudo e decidiu que não partiria para o outro mundo sem liquidar o caso. Pediu que chamassem Maria de Lourdes pela última vez. Ela veio, chorando, torcendo as mãos, em companhia de Leotário. O moribundo implorou baixinho, mas em tom bastante distinto para que todos ouvissem:

- Jura, Maria de Lourdes, jura que fui eu quem fez mal a você...

Ela caiu de joelhos, molhando a beirada da cama com suas lágrimas desesperadas:

- Não, não, juro que não foi você... Não é seu este filho que vai nascer!

As suas últimas palavras, Alfredo já não ouvia. Alguém, piedosamente, acendeu uma vela ao lado. ${ }^{108}$

Nesse primeiro texto temos a inserção dos nomes reais, dos cenários e enredo da notícia aplicada ao conto. Mas, nos dias seguintes, o jornal passa a publicar, além dos nomes reais, suas fotos, sobrepondo a realidade à ficção e viceversa. Foi assim nas histórias "O crime da praia", de 9 de abril de 1952, em que a protagonista na vida real, Lindaura Amorim, mulher da vítima, surge numa foto diante de uma sala gradeada onde estava preso seu amante e cúmplice, Murilo Costa. A história é de um triângulo amoroso, como muitas de "O Crime do Dia". Lindaura na vida real, Dinaura na ficção de Lúcio, seduziu um amante para assassinar o próprio marido. Ao contrário de "A mulher de Caruaru", outro conto ilustrado pela fotografia da própria assassina, que seduzia e envenenava seus amantes quando um novo amor surgia. Neste conto também é publicada a imagem

${ }^{108}$ CARDOSO, L., “Assassínio por engano”, op. cit. 
da assassina real. Por meio dos dois registros, o ficcional, em que o autor surge como a autoridade, e o discurso real, em que a história em si, a presumida verdade, assume a autoridade do texto, temos um novo tipo de narrativa, que "se baseia não no conhecimento da verdade (o discurso jornalístico), mas na mera verossimilhança dos fatos". ${ }^{109}$ Essa novidade na obra do autor o coloca diante de uma questão muito cara, muito debatida desde meados da década de 1930, quando lança A luz no subsolo, até os anos 1940 com as novelas satânicas. Nestes períodos, angaria incompreensão da crítica, que vê em suas histórias e em seus personagens, principalmente, uma inverossimilhança prejudicial para a aceitação (do leitor) e para aquela "aparência" de verdade necessária aos romances de então. Anos depois, em maio de 1959, o escritor liquida a questão. Em resposta ao crítico e poeta Walmyr Ayala, que o questiona sobre como utiliza e transcende a realidade em seus romances, Lúcio afirma que "tudo é realidade", desfazendo suas certezas de anos atrás, quando tudo era imaginação.

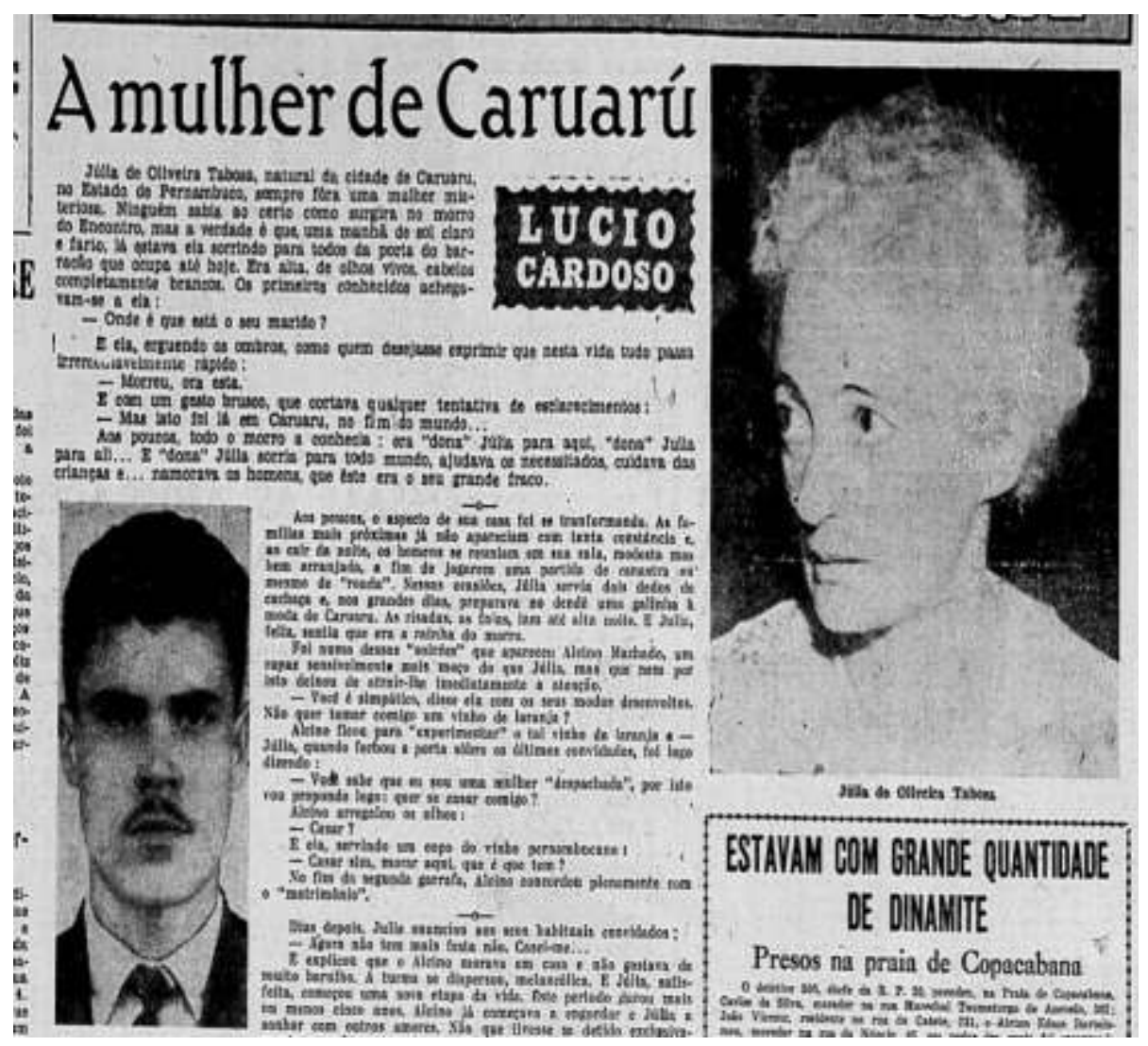

Figura 2 - "A mulher de Caruaru".

Fonte: Coluna de O crime do dia, A noite, Rio de Janeiro, sábado, 12 de Abril de 1952.

${ }^{109}$ SANTIAGO, S., Uma literatura nos trópicos, Rio de Janeiro: Rocco, 1978, p. 33. 
Em "O Crime do Dia" as pobres paixões e loucuras humanas, transformadas em crimes passionais, pululavam. Na conversa com sua irmã, reproduzida no livro Vida Vida, o escritor lembra exatamente sobre as artimanhas criminosas de Dinaura, na Praia das Bandeiras, Ilha de Governador, reproduzidas em "O crime na praia”. Segundo Lúcio, este teria sido o primeiro texto escrito para a coluna, embora tenha sido o sétimo a ser publicado. Nos contos, Lúcio usa da empatia para se colocar na pele dos assassinos, exemplificando quase sempre seus motivos, mesmo que fúteis, no caso de Dinaura, para matar.

O mal de Dinaura era o tédio. Por isto, somente por isto, travou relações com um homem que sempre passava diante da sua casa, um mulato chamado Murilo Costa. Não sabe direito quando o viu pela primeira vez — lembra-se apenas que, um dia, debruçando-se à janela, dera com o vulto recortado contra a fimbria do mar: parecia um pescador, à espera de oportunidade de lançar a tarrafa. No primeiro momento, repugnou-lhe travar relações com aquele indivíduo, mas depois, como sua natureza não se embaraçasse grandemente com escrúpulos, perguntou a si mesma: que é que tem que ele seja mulato? Mulato também é gente, e pode ser até que seja gente muito boa. ${ }^{110}$

Registrou várias partes da cidade e da Baixada Fluminense, falou da Lapa, de Nova Iguaçu, de Paquetá, do morro do Salgueiro, do centro da cidade, do Leblon e de Ipanema. Evocou um Rio de Janeiro de pensões e das primeiras lojas de departamento, Casa Sloper, a Sears, e restaurantes famosos como a Confeitaria Colombo e ruas centrais como do Ouvidor e Gonçalves Dias. Expôs seus personagens ao racismo e machismo da época, e também à sua própria misoginia, acentuada na maioria dos textos. As mulheres matavam por futilidade ou tédio, como ocorrido em "O crime da praia", "Os alfinetes de prata", "O poço", dentre vários outros. Os homens, por descontrole ou ciúmes, como em "O açougue”, "O vestido de baile" ou "O monstro de olhos verdes".

Dentre os temas mais recorrentes estão o crime passional, os triângulos amorosos, a mulher, a cidade, o trabalho, o sexo, o misticismo, a Igreja Católica, a violência sexual e, curiosamente, a presença do outro, como ciganos, europeus e judeus que se refugiaram na cidade durante a guerra. A enorme galeria de tipos inclui ainda homens malandros, usurpadores, garotos assassinos, padres e profanadores, mulheres traiçoeiras e sofredoras. Surge pela primeira vez na prosa

\footnotetext{
${ }^{110}$ CARDOSO, L., "O crime da praia", A Noite, Rio de Janeiro, seção Risos e Lágrimas da Cidade, O Crime do Dia, quarta-feira, 9 de abril de 1952, p. 9.
} 
do escritor a vida íntima de trabalhadores humildes - nos contos gerais esses personagens estão presentes, bem como as videntes nas novelas fantásticas, mas aqui, quase sempre há uma ênfase muito maior do trabalho, embora a intimidade apareça em primeiro plano. São costureiras, relojoeiros, empregadas domésticas, pequenos comerciantes que enfileiram as histórias.

Como nos contos gerais, dividimos os escritos de crime em seis itens gerais: o ano de publicação; o gênero e tipo de personagens, se homem, mulher, criança ou animal; a situação social e cultural dominantes/o estado de espírito: se classe média suburbana, se rico, se pobre, se louco e ciumento, fracassado, doente e se há triangulo amoroso e morte. O tema, se é regional/proletário, crime passional, memória, fantástico ou policial. O cenário, se tem o mar, cais/barca, se é urbano ou suburbano. E, por último, se está na primeira pessoa ou se tem um narrador.

Selecionamos 33 contos para representarem os 265 textos da coluna. Nosso conto emblema teria uma mulher como protagonista, uma vez que $76 \%$ dos textos têm mulheres como personagens principais, enquanto $67 \%$ homens e o mesmo número casais. $58 \%$ das histórias redundaram em morte. Apesar de ser um número alto, isso nos mostra que a morte não era o fim de todos os crimes, dividindo com ela a loucura, o triângulo amoroso, o sexo, a doença e, finalmente, um aspecto bastante conhecido de nossos personagens cardosianos: o fracasso, presente em $21 \%$ desses contos. Depois da morte, o que mais mobilizou os enredos do escritor foram os triângulos amorosos, presentes em $30 \%$ dos textos analisados.

A pobreza, que nos contos gerais acomete $35 \%$ dos personagens, aqui $27 \%$ dos protagonistas é pobre, enquanto $61 \%$ são de classe média e classe média suburbana. Os cruzamentos de classes sociais, ou seja, a convivência entre ricos e pobres, personagens da Zona Sul com aqueles do subúrbio surgiu com frequência na coluna, como em "As duas irmãs" e "O amante". No primeiro, um rapaz da Zona Sul seduz e rouba duas irmãs empreendedoras que ganham dinheiro com um bar nas mediações do Maracanã. A perversidade está no fato de uma delas ter sido empregada doméstica na casa do ladrão e ter se apaixonado pela ideia de se casar com seu ex-patrão. O segundo é a história de um rapaz suburbano que se passa por jornalista para seduzir mulheres ricas da Zona Sul. Em ambos, como na maioria dos contos, o sexo e a sedução é a moeda de barganha e de diálogo entre 
gêneros e classe sociais, em que o mais forte economicamente subjuga o mais fraco e vence.

O crime passional foi o tema mais abordado dentre os contos, surgindo em $40 \%$ dos textos analisados. Em seguida, com 27\%, vem o gênero policial, com um pouco de suspense, perseguição, análise e revelação. Mas o que surpreendeu nesse quesito "tema" foi a presença de $12 \%$ de contos em que a memória e as lembranças predominam na história. $\mathrm{O}$ cenário, como prevíamos, é majoritariamente urbano, tendo a cidade do Rio de Janeiro e seus núcleos suburbanos como cenário de $64 \%$ das histórias. Outro local muito presente é o mar, praias e ilhas, incluindo mais uma vez Paquetá, em 17\% dos casos. O cais do Rio aparece em $6 \%$, e o ambiente rural da maior parte de seus romances está representado em $9 \%$ dos contos publicados. Por último, a pesquisa mostrou que em $100 \%$ das vezes o narrador é em $3^{\text {a }}$ pessoa, sendo Lúcio o grande porta-voz de todos os personagens e de todas as histórias reais, ou fictícias, publicadas em $A$ Noite.

Alguns aspectos nos surpreenderam nessa pesquisa e análise, e não são os crimes, que como já sabemos são majoritariamente passionais. Também não é o machismo, que rege o relacionamento de personagens masculinos com as mulheres dentro do ambiente doméstico, sejam elas parceiras ou filhas. Em nossa lista, quatro aspectos desses contos, que não representam maioria quantitativa, nos chamam a atenção. Um deles é um certo memorialismo melancólico, histórias de uma infância anônima, como "A casa", em que um jovem retorna ao local de infância quando não há mais ninguém à sua espera.

Um dia a filha não voltou mais. O tempo, implacável, acumulava a sua ira sobre essa casa semi-arruinada. $\mathrm{O}$ menino fazia-se grande, e ganhou o mundo também. Por onde andou, ninguém sabe. Mas fez-se homem, duas rugas fundas nas faces, os lábios descorados, os olhos mansos. Os olhos mansos de quem havia visto a luz através da paisagem escura da estrada. Os olhos mansos de quem tem o coração apaziguado. ${ }^{111}$

Um segundo tema que merece ser destacado é a inserção do ambiente físico religioso, não só o católico, com suas igrejas e conventos, também histórias que se passam em terreiros de umbanda e candomblé. Além das religiões, há a presença

${ }^{111}$ CARDOSO, L., "A casa”, A Noite, seção Risos e Lágrimas da Cidade, O Crime do Dia, Rio de Janeiro, sábado, 12 de julho de 1952, p. 9. 
frequente de videntes e outros místicos. Em "O profanador" temos um exemplo de conto em que o efeito único é usado com destreza pelo autor. $\mathrm{Na}$ história, um padre se torna assassino para defender a igreja de um jovem líder de uma gangue de rua que resolve invadir a sacristia e roubar o cálice de ouro. O medo do castigo divino divide o grupo e paralisa a gangue, mas o líder invencível sobe os degraus e ergue a taça de ouro ainda com vinho. E morre pelas mãos do padre.

Avançou para o altar-mor, uma vela nas mãos. Reflexos de ouro cintilavam à sua passagem - toda uma vida estranha e efêmera fazia palpitar as imagens. Um morcego irrompeu de uma das pequenas janelas e mergulhou cegamente no espaço livre da nave. Ernesto, sem hesitar, chegou ao último degrau, estendeu a mão, abriu o tabernáculo e se apossou do cálice. Voltou-se, e durante um minuto, o objeto refulgiu na semi-escuridão:

- Ainda há resto de vinho, pessoal... - exclamou.

E levou o cálice aos lábios. Neste momento, trêmulo, o cobertor escorrendo-lhe aos pés, o vigário atirou! O estampido reboou surdamente pela igreja. Ernesto ainda ergueu o cálice, que chispou um minuto, tombou de suas mãos, rolou até em baixo. ${ }^{112}$

Uma das histórias que tem a religião como cenário e tema coloca em questão a repressão de uma suposta homossexualidade entre meninas de um orfanato: "Nos seus olhares, bem como nos modos ardentes e desajeitados, percebia-se essa coisa luminosa e extravagante que é a mocidade - a extrema mocidade". ${ }^{113}$ A ira da freira, e o desespero das garotas transformam o conto "Orfanato" numa das histórias mais expressivas e contemporâneas da extensa lista. Aqui ele não segue mais a receita anterior de retirar da realidade do noticiário suas histórias; ao contrário, cria uma realidade em que alguns valores estavam sendo colocados em questão, em debate, mesmo que por meio da ficção.

- Coisas muito graves se passaram ontem aqui...

E numa linguagem obscura, sibilina, referiu-se a qualquer crime monstruoso e secreto, cometido por duas meninas - e todos os olhares, como se traduzissem através de suas palavras a condenação das colegas visadas, voltavam-se

\footnotetext{
${ }^{112}$ CARDOSO, L., "O profanador”, A Noite, seção Risos e Lágrimas da Cidade, O Crime do Dia, Rio de Janeiro, segunda-feira, 16 de junho de 1952, p. 5.

${ }^{113}$ CARDOSO, L. "Orfanato", A Noite, seção Risos e Lágrimas da Cidade, O Crime do Dia, Rio de Janeiro, sexta-feira, 26 de setembro de 1952, p. 11.
} 
implacáveis para Stela e Sofia, esta última trêmula e pálida, os olhos baixos como se reconhecesse toda extensão da culpa. ${ }^{114}$

O ambiente do orfanato, como local de confinamento e repressão, surge em mais de um texto. No segundo conto chamado de "Orfanato" protagonista vê na morte de uma das internas uma beleza maior do que a vida e se prepara para morte com calma e resolução. Neste o autor apresenta o suicídio como um gesto metódico e apaziguador.

Um silêncio perfeito reinava em torno dela, o cheiro das rosas ganhou-a, tudo se confundiu de repente, e a menina sentiu o mundo dilatar-se e uma estranha aurora romper suas luzes triunfais sobre sua consciência afinal liberta para sempre deste mundo. ${ }^{116}$

A presença do estrangeiro em muitos dos contos do período merece uma especial atenção. Europeus, ciganos e judeus convivem com a realidade brasileira e com a nova sociedade a partir de suas culturas. Nos contos "Os ciganos" e "O prisioneiro", o encontro das culturas é o tema principal e, claro, os conflitos advindos dessa relação. Por último, gostaríamos de destacar a presença maciça das mulheres nesta coleção. São muitos os tipos de mulheres criados pelo escritor e as situações que envolvem o gênero feminino. Mortes trágicas ("O açougueiro"), seduções fáceis, ciúme masculino que redundam em morte ("O vestido de baile", "O monstro de olhos verdes"), repressão ("Orfanato") e violência fazem parte do universo dessas mulheres, além da propalada disputa e intriga femininas ("Os alfinetes de prata”). Não é confortável o lugar feminino na obra de Lúcio Cardoso, basta relembrarmos algumas de suas personagens marcantes em seus romances como Nina, de Crônica da casa assassinada ou Adélia, de $O$ enfeitiçado. A primeira, uma mulher forte, cuja marca é a lascívia, confundida com uma modernidade incompreendida pelo clã rural tradicional e decadente dos Meneses. A segunda, Adélia, é fraca, submete-se às traições de sua mãe, a vidente Lina de Val Flor, que a prostitui disfarçadamente. Em "O Crime do Dia" de cada mulher

\footnotetext{
${ }^{114}$ Idem.

${ }^{115}$ Lúcio repetiu o título em vários contos. Encontramos os seguintes títulos em duplicata: A casa,Um caso banal, $\mathrm{O}$ noivo, Orfanato, Acidente e $\mathrm{O}$ passageiro.

${ }_{116}$ CARDOSO, L., "Orfanato", A Noite, seção Risos e Lágrimas da Cidade, O Crime do Dia, Rio de Janeiro, quarta-feira, 13 de maio de 1953, p. 10.
} 
vitoriosa, temos 50 assassinadas, esquartejadas, sedutoras, prostituídas, fúteis, violentadas e ladras.

\section{"Amavam-se na areia como animais"}

Dinaura e seu amante Murilo, o assassino do marido, "amavam-se na areia como animais"117 e tramavam a morte por debaixo das sombras noturnas das amendoeiras em dia de Lua. "O mal de Dinaura era o tédio. Por isto, somente por isto, travou relações com um homem que sempre passava diante da sua casa", anuncia o autor. Tédio. Dinaura era uma mulher entediada. Poderíamos centrar nossa análise nos triângulos amorosos, pela fartura com que são tratados nos contos de crime, mas nos questionamos quem é essa mulher cardosiana que representa $76 \%$ dos personagens de seus contos de crime? São assassinas? São vítimas?São trabalhadoras? Lúcio desenvolveu uma enorme galeria de mulheres, as principais personagens desses contos, mesmo quando contracenam com homens. A coluna, como explicamos anteriormente, era voltada para o público urbano e suburbano e as personagens espelham a realidade dos leitores do jornal: mulheres da pequena burguesia que se dividiam entre os afazeres domésticos e o trabalho, ou entre os afazeres e o tédio da vida suburbana. Dentre tipos criados pelo autor, sobressai a mulher sem escrúpulo, sedutora, geralmente casada e que almeja outra vida. Esta não mede esforços para atingir seu objetivo, apelando, na maior parte dos casos, à morte dos maridos. Há visivelmente nos contos uma assimetria. Se a personagem é casada, infeliz e ambiciosa, pode se tornar uma mulher sedutora e inescrupulosa e, portanto, agente principal do crime, cometendo-o ou seduzindo um incauto para cometê-lo. Foi o caso de Dinaura, em "O crime da praia". Para as mulheres casadas, a morte do outro é desejada, pois é a chave da liberdade, como no conto "O poço", em que a mulher nega ajuda ao marido caído dentro do poço. Enquanto a morte chega paulatina, ela desabafa, sem pedir ajuda e sem remorsos:

- Vou-me embora, Inocêncio, vou-me embora para outra cidade, para outra vida. Vou dizer uma coisa a você, uma coisa que eu sempre pensei de noite, olhando a sua cara: nunca o amei, nunca tive por você o sentimento normal que uma mulher

${ }^{117}$ CARDOSO, L., "O crime da praia”, op. cit. 
tem para um homem. Detestava-o, mas tinha medo. Achava-o horrível, e trabalhava como uma escrava. Mas nunca fui fiel, ao contrário. Traí você com todos os homens que me lançaram um olhar, com aquele vendedor de enceradeiras que foi lá em casa, você se lembra? Dormimos no quintal, em cima de um monte de folhas secas... E dormi com uma porção mais, dormi com todo mundo, com todos que tinham vontade de me sujar... para que eu fosse sua depois, Inocêncio... ${ }^{118}$

Se a sedutora manipula a cena, vinga-se do homem e o aniquila, a virgem é derrotada socialmente ao "converter-se em amante". Em "Um homem de sorte", a mocinha vendedora da Casa Sloper, virgem, conhece o homem de seus sonhos, um rapaz elegante e aparentemente bem empregado. O pai, português desconfia, mas o namoro prossegue, daí surgem as dificuldades financeiras do noivo, que não oficializa o compromisso. Ela apaixonada. Ele a seduz e a leva para uma pensão. Ela perde a virgindade e se vê diante de um cafetão, que a escraviza:

Convertida em amante, passou a conhecer quem realmente era aquele homem. Um bruto, um monstro. Espancava-a por qualquer coisa, pretextando que ela não sabia trabalhar, que não prestava para coisa alguma, que tinha vindo apenas para empatar sua vida. Magra, inteiramente diferente, ela fitava-o com os olhos cheios de lágrimas, sem nada responder. Pena que o amasse tanto, que ele a tivesse enganado a necessitar dele daquele modo. ${ }^{119}$

O desfecho não podia ser menos dramático e convencional: o pai da jovem a encontra na Central se prostituindo e, se dá o diálogo fatal:

—Léa, que é isto?

Ela apenas afastou o soldado e gemeu:

- Oh, meu pai...

Ele segurou-a pelo braço, foram andando, ela de cabeça baixa, as lágrimas escorrendo, desmanchando a pintura barata. E sem forças para suportar mais, contou tudo, a história do hotel, a mudança, os maus tratos que o amante lhe infligia. O pai, petrificado, escutava-a quase sem acreditar. Léa arrematou a sua história:

- Agora, não quer mais que eu fique em casa. Devo girar o dia todo, oferecendome, a fim de obter algum dinheiro...

- E há muito tempo que você faz isto?

Ela ocultou o rosto, dizendo baixo:

— Há três semanas.

\footnotetext{
${ }^{118}$ CARDOSO, L., "O poço", A Noite, seção Risos e Lágrimas da Cidade, O Crime do Dia, Rio de Janeiro, sábado, 17 de maio de 1952, p. 10.

${ }^{119}$ CARDOSO, L., "Um homem de sorte", A Noite, seção Risos e Lágrimas da Cidade, O Crime do Dia, Rio de Janeiro, sábado, 19 de abril de 1952, p. 10.
} 
O português levantou-se, sem dizer palavra. Sabia o que tinha a fazer. Abandonou a filha e, esmagado, dirigiu-se para casa. ${ }^{120}$

O português, para honrar a filha e a si próprio, como a figura paterna de “Assassínio por engano", resolveu fazer justiça. Conseguiu uma velha "garrucha", percorreu todo o Centro do Rio e adjacências até encontrar o malandro. E atira uma, duas, três vezes. E erra. É preso, e a filha, aos prantos, retorna à casa do cafetão, que a rejeita e expulsa.

Era Léa, que se atirou a ele, tentando retê-lo:

- Geraldo, juro como não sou culpada!

Ele empurrou-a brutalmente com o pé, exclamando:

— Não, na minha casa você não entra nunca mais... ${ }^{121}$

Não há uma história de perda de virgindade que tenha redundado em liberdade, prazer ou felicidade. Para essa mulher, o corpo é marcado pelo pecado e pela corrupção social. E uma vez estigmatizada, prostitui-se. Seu pai, ${ }^{122}$ por sua vez, é agora um assassino condenado socialmente. Quando essa mulher, solteira, engravida, existem apenas dois caminhos: a prostituição ou o suicídio, como veremos no conto "Wanda". Sobre a figura paterna, esse conhecido personagem cardosiano, lembramos que está presente, com destaque, em duas importantes obras do autor: no autobiográfico Dias perdidos e em Maleita. Daniela Borja, no artigo "À procura do pai" ${ }^{123}$ lembra que o "significante" pai é "objeto de referência e reflexão constantes" na obra de Lúcio. Segundo Borja, o pai precisa ser morto, e nesses contos de fato ele é morto e aniquilado, mas não como em "Totem e Tabu", de Freud, em que o desaparecimento do pai está relacionado à nova ordem do filho que destitui-lhe a autoridade. De certa forma, a liberdade das mulheres expressa pela perda da virgindade redunda no ocaso da autoridade paterna. Lúcio, socialmente impiedoso, destrói o pai a partir do prazer da filha.

\footnotetext{
${ }^{120}$ Idem.

${ }^{121}$ Idem.

${ }^{122}$ É interessante observar que a figura materna nesses contos é pequena.

${ }^{123}$ BRANDÃO, R. S. (org.), Lúcio Cardoso, a travessia da escrita, Belo Horizonte: Humanitas/UFMG, 1998, p. 68.
} 
Em "Wanda", ${ }^{124}$ a jovem Maria do Carmo conhece o elegante Reynaldo num passeio ao Leblon, se apaixonam e começam um namoro.

Como sempre acontece, o apartamento era um hotel sórdido, e ali, naquele horrível ambiente, Maria do Carmo teve a vaga intuição, pela primeira vez, de quem era realmente aquele homem. Digo vaga, porque ele aplainou todas as dificuldades, jurando que se casaria, que estava apenas a espera de uma melhora nos vencimentos, etc. - o clássico golpe. Ela não tinha nenhum motivo para duvidar - até que, com os primeiros sintomas de gravidez, foi obrigada a lembrar-lhe a promessa feita:

— Ih, meu bem, disse ele, que massada! Que é que nós faremos agora? ${ }^{125}$

Grávida, foi morar com o amante numa pensão no Méier e lá mesmo fez um aborto. Os personagens masculinos nesses contos de "O Crime do Dia", ou são tomados pelo ciúme e pela vaidade, se tornando assassinos e criminosos, ou são como Reynaldo, fracassados e dependentes do trabalho feminino, mesmo que o trabalho seja sexual. É o que acontece nesse texto em que a jovem se transforma, nas noites dos cabarés, em "Wanda".

As saídas se multiplicaram: agora iam todas as noites para um "cabaret" de Copacabana, onde Reynaldo lhe apresentava sucessivos amigos. Era gentil com todos, não podia negar coisa alguma, e aceitou aquela vida com indiferença, como aceitaria qualquer coisa. Até que um dia, quando voltavam para casa, sem ter obtido o sucesso costumeiro, Reynaldo propôs:

- Há alguma coisa conosco que não vai bem. Este nome de Maria do Carmo soa esquisito... O melhor de agora em diante, é você se chamar Wanda.

E desde então ficou sendo Wanda. Tinha sua mesa reservada, fregueses conhecidos. Prosperavam. Às vezes, como pálida e cabisbaixa ela se entregasse a um desespero sem remédio, o amante brandiu-lhe diante dos olhos um maço de notas:

— Boba, não vê que está tudo bem? Temos dinheiro... e você me tem... que é que precisamos mais? ${ }^{126}$

O escritor não encontrou nenhuma outra saída para Maria do Carmo, agora convertida em Wanda, além do suicídio libertador:

\footnotetext{
${ }^{124}$ CARDOSO, L., "Wanda", A Noite, seção Risos e Lágrimas da Cidade, O Crime do Dia, Rio de Janeiro, sábado, 10 de maio de 1952, p. 9.

${ }_{125}$ Idem.

${ }^{126} \mathrm{Idem}$
} 
Então ela retirou da bolsa dois tubos de "Adalina" que comprara, pediu um chope, misturou tudo e ingeriu o líquido grosso, tranquilamente, sem nenhum asco. [...]. Agora, calma, aguardava o grande sono, reconciliada consigo mesma e com a miséria do mundo. ${ }^{127}$

O espírito do escritor, como afirma Blanchot, trabalha em direção a uma única obra. A obra literária "não é acabada, nem inacabada: ela é". ${ }^{128}$ Portanto, podemos acrescentar que o escritor trabalha em torno de sua única obra, à qual ele pertence, não importando muito o formato. A obra é. E as várias obras de um autor estão em permanente contato, pois todas confluem para essa obra única. Percebemos nesses contos, mesmo sendo feitos para a imprensa e, por isso, estando sob a urgência e a factualidade que o jornalismo emprega às suas narrativas, o surgimento de alguns temas e personagens recorrentes. É o caso da personagem do conto "A sedutora": durante anos, Violeta, a sedutora, esteve separada do filho que vivera sob a guarda do pai, mas resolve voltar, se aproximar e lhe envia duas cartas pedindo um encontro, sem anunciar que se tratava de sua mãe há tantos anos desaparecida. O rapaz desconfia, mas aceita as investidas, e filho e mãe se reaproximam.

Ele estremecia, de prazer e perturbação: não estava acostumado a ter mãe, e aquela mulher sentada à beira de sua cama causava-lhe um esquisito mal-estar. Imaginava os colegas entrando ali e encontrando-a sentada o seu lado - ainda tão jovem que até poderia passar por sua namorada! Violeta, acariciava-o, chamando-o de nomes ternos, as coisas de antigamente. Ele deixava-a fazer, paralisado, como se ela exercesse uma ação direta sobre os seus nervos, uma espécie de sortilégio.

Despediu-se naquele dia, prometeu voltar dentro em pouco. E durante muito tempo, persistente e com um sabor de pecado, seu perfume flutuou pelo quarto, deixando o estudante desperto e com o coração cheio de ansiedade. ${ }^{129}$

Em uma de suas visitas ao alojamento do filho, sentada à beira da cama, Violeta, sem maiores pudores, beija o filho na boca, o que transtorna o jovem.

Sentou-se ao seu lado e tomou-lhe as mãos como habitualmente - ele deixou-a fazer, mas súbito, tonto, debruçou-se sobre ela e, brutalmente beijou-lhe os lábios. Um tumulto se fizera no seu pensamento, e ele julgava ter cometido um crime. Mas

\footnotetext{
${ }^{127}$ Idem.

${ }^{128}$ BLANCHOT, M., O espaço literário, Rio de Janeiro: Rocco, p. 12.

${ }^{129}$ CARDOSO, L., "A sedutora”, A Noite, seção Risos e Lágrimas da Cidade, O Crime do Dia, Rio de Janeiro, sábado, 28 de junho de 1952, p. 11.
} 
Violeta, como se aquilo fosse a coisa mais natural do mundo, puxou-o para si, beijou-o novamente e estendendo-se, arrastou-o para o seu lado. ${ }^{130}$

O filho, assustado e ferido, expulsa a mãe de seus aposentos e sente-se profundamente traído, duplamente traído, primeiro pela mãe que o abandona e, segundo, pela mãe que age como uma "prostituta", termo usado pelo escritor. "Levantou-se de súbito e contemplou-a - estava inerte, os olhos cerrados. Então, ergueu a mão e, quase sem saber o que fazia, esbofeteou-a". ${ }^{131}$ Ao final, o autor concede àquele jovem uma maturidade precoce e o transforma de um menino em um homem, como efeito do beijo inesperado: "aquelas horas haviam-no transformado num homem, maduro para todos os acontecimentos".

Violeta nos lembra Nina, que só surgiu sete anos depois como a personagem incestuosa de Crônica da casa assassinada. A crítica à Crônica foi impiedosa com o sugerido incesto entre Nina e André. No texto "Um romance brasileiro", Wilson Martins faz coro, em 1959, com a crítica moralista:

\begin{abstract}
Nina que existia numa esfera diferente da humanidade comum, que era até então (até o leitor conhecer que o homem por quem ela estava aparentemente apaixonada era seu filho) uma rainha da tragédia, afrontando e enfrentando na sua inocência pessoal, a maldição injustificada dos deuses, transforma-se, de repente, numa mulher comum, entregue às "loucuras" da carne", como dizem os moralistas, mas já sem a grandeza, sem a majestade de sofrimento e de paixão que a caracterizava. [...] Tirando-lhe esse caráter, o Sr. Lúcio Cardoso, desceu, um pouco da tragédia ao "vaudeville". ${ }^{132}$
\end{abstract}

O que queria Lúcio Cardoso com essa mulher sedutora, capaz de desafiar o status quo, a sociedade e seus costumes mais sagrados para realizar plenamente seus desejos? Que corpo é esse, marcado por tapas filiais, prostituição, crimes e sexo? Essa mulher do vaudeville a que o crítico se refere nada mais é do que a representação maior de todas as perversões possíveis, sem culpa, sem morte, isto é, o crime moral que a todos atordoa, poucos defendem e contra o qual muitos lutam. Lúcio Cardoso é um o escritor que mantém “o leitor na beirada da morte, nessa posição de mal-estar, ao mesmo tempo dominado pelo clima de mistério e

\footnotetext{
${ }^{130}$ Idem

131 Idem.

${ }^{132}$ MARTINS, W., "Um romance brasileiro”, O Estado de S. Paulo, São Paulo, 1 de agosto de 1959.
} 
pela paixão". ${ }^{133}$ Um autor que possibilita a esse mesmo leitor uma viagem aos mais insondáveis gestos humanos, pensamentos e ações reais, apenas abafadas pela moral e costumes. A Lúcio coube a missão de nos revelar o desconforto, o bestial e o inaceitável.

${ }^{133}$ BEDRAN, A. M., “A paixão segundo Lúcio Cardoso”, in: BRANDÃO, R. S. (org.), op.cit., p. 136. 


\section{5 \\ Conclusão}

É finda a longa viagem, de tantas histórias, de tantas guerras e apaziguamentos. Lúcio me ensinou, dentre as muitas lições aprendidas nas páginas descobertas e nas outras lidas e relidas, o quanto a paisagem é valiosa. Não só da natureza, mas, sobretudo, a paisagem humana da qual era devedor. Não conseguia ficar muito tempo no Rio de Janeiro, mesmo que diante do mar. Precisava ver o interior, o chão poeirento das estradas vicinais de Minas Gerais ou do interior do Estado do Rio. Por outro lado, também não entendia a paixão de seus amigos por viagens tão distantes, tão longas e cansativas, com oceanos e céus a serem cortados. Nunca saiu do Brasil. E nas poucas crônicas que escreveu se dizia um observador acomodado, para quem o melhor lugar era à mesa, diante de sua máquina de escrever ${ }^{134}$ ou de um copo de vinho.

E foi dessa forma que nos legou o objeto maior deste trabalho: seus contos. Durante a pesquisa, a cada leitura, a cada descoberta, me perguntava o motivo de o escritor ter relegado a segundo plano um volume tão gigantesco quantitativamente, e com uma qualidade igualmente enorme. É claro que existem altos e baixos, principalmente nos contos escritos no calor da urgência, como os de crime. Mesmo assim, a princípio nada justificaria para mim, leitora do século XXI, um descaso com obra volumosa e importante.

A tese seguiu desde o princípio por dois caminhos: o primeiro, o da pesquisa, quase braçal, de cruzamentos de informações em fontes primárias, como correspondências e recortes de jornais, no acervo do escritor no Arquivo Museu de Literatura Brasileira da Fundação Casa de Rui Barbosa e em muitos periódicos, encontrados, hoje, em sua maioria, na Hemeroteca Online da Biblioteca Nacional, que durante nossa pesquisa ainda não existia. Passamos mais de dois anos fazendo o levantamento de todos estes textos nos jornais microfilmados na Seção de Periódicos da BN. Realizamos, assim, uma pesquisa com etapas muito claras, metodologia e metas a serem cumpridas. Primeiro, desenhamos um mapa de toda

\footnotetext{
${ }^{134}$ CARDOSO, L. "Viagens", Revista da Semana, O Acontecimento da Semana, Rio de Janeiro, segunda-feira, 9 de outubro de 1954, p. 3.
} 
a produção artística conhecida do escritor, com data, título, periódico, editora. Inserimos desde seus roteiros de cinema, a traduções, seus romances e novelas, peças de teatro, e os contos e crônicas já revelados pelos pesquisadores anteriores. Diante desse quadro da "fortuna" localizamos as áreas em branco. Anos como os de 1951, 1952 e 1953 eram desoladores e nenhum escritor com a sua verve e a produção, até então conhecida, poderia ter vazios expressivos como aqueles. Nossa pesquisa começou justamente pela falta e ausência. E assim refizemos os caminhos do escritor e as surpresas foram tantas que chegaram a ecoar na Biblioteca Nacional, pois no dia em que o primeiro conto de crime foi encontrado, um grito foi ouvido:

- Finalmente!

Preenchendo as lacunas do vazio bibliográfico encontramos parte dessa produção ficcional, mas era ainda preciso explicar os motivos que levaram o escritor a não publicar, em vida, uma seleta dessa obra. Lúcio mencionou em seu próprio diário os contos, e a vontade de publicá-los, até o título já havia feito: Contos do continente. Seria, então, também uma questão geracional o desinteresse pela publicação dos textos curtos? Ou o escritor compreendia a obra literária como uma única realização, possível somente no romance e na poesia?

Fomos, por isto, em busca da recepção de sua obra desde a década de 1930 até a década de 1950 quando lança seu livro mais conhecido e admirado Crônica da casa assassinada, de 1959. Buscamos respostas (e encontramos algumas) na obra do escritor, em sua vida e, sobretudo, na literatura brasileira. Até que ponto o conto não era considerado uma obra menor para esses autores? Como ele foi inserido no período? E descobrimos que sim, o conto, o gênero curto, ao menos para os jovens que surgiram nos anos 1930 não era mais o gênero predileto como um dia foi para Machado de Assis e como foi, mais tarde, para os autores da década de 1950, sobretudo para aqueles que se debruçaram sobre o cotidiano, fincando a crônica (e não o conto) como o gênero curto predileto da literatura brasileira naquele período. Hoje, no século XXI, tanto a crônica como o conto perderam seus espaços entre os escritores e, principalmente, o suporte da imprensa e casas editoriais, enquanto o romance é o gênero mais produzido e publicado. E a poesia, embora ainda continue sendo tão escrita quanto em todos os tempos, não tem leitores e muito menos editores interessados. 
Concluímos também que a força da imprensa na criação de concursos e de espaços para o conto na literatura brasileira, entre as décadas de 1930 e 1950 foi fundamental para pavimentar o alicerce para a criação de novos autores e leitores do gênero. E os destaques foram, claramente, a revista Acadêmica e o suplemento "Letras e Artes" de A Manhã. Nesses dois espaços Lúcio exerceu com mais liberdade e com frequência o conto, e outros autores, a exemplo de Clarice Lispector e Dalton Trevisan, surgiram como contistas, além de Guimarães Rosa ter deixado o depoimento fundamental sobre Sagarana nas páginas da coluna de João Condé, também no suplemento. O grande divisor de águas para o conto, na imprensa do século XX, e que de certa maneira impulsionou a produção de Lúcio Cardoso, foi definitivamente o surgimento do suplemento "Letras e Artes" do jornal A Manhã. A década de 1940 foi generosa na divulgação do gênero e na inserção de intelectuais em altos cargos nos jornais. Esse cenário se confirmou promissor para o surgimento dessa literatura curta, como apelidavam os jornais.

Mas o fato é que, apesar de os meios garantirem espaços para a literatura brasileira, ainda mais das décadas de 1930 a 1950, o conto não foi popular entre os escritores do romance do Norte, e da prosa como um todo, na década de 1930. Para compreendermos os motivos dos escritores de 30, nos voltamos para o período, para as discussões e polêmicas em torno da literatura enquanto ferramenta de política social, como entendiam alguns autores do romance regionalista e do romance proletário. $\mathrm{O}$ romance era o instrumento de transformação. Não havia espaço para nenhum outro formato que não fosse este, um texto, em sua maioria, documental e longo, o receptáculo da história - ao contrário do que propôs Walter Benjamin, no período, sobre a relação entre o narrador e o romancista, sendo o narrador o cronista político e social. No romance brasileiro político e de afirmação social, o cronista era o romancista que a partir de seu entendimento entregava à sociedade denúncias sobre a vida real, social, em oposição a tudo que era subjetivo e individual. O herói foi exilado.

Muito cedo Lúcio percebeu a distância entre a sua compreensão de literatura e o que vinha sendo feito pela maior parte dos escritores. As polêmicas cindiram o momento literário de meados de 1930 até final da década de 1940; um momento rico e que nos colocou importantes questões sobre o poder da literatura na transformação social. E, por outro lado, se de fato esse poder não era apenas extrínseco à obra e não intrínseco, como queria Jorge Amado, principalmente. 
Lúcio encontrou motivos de sobra para renegar todo o realismo regional de seus dois primeiros livros e partiu para uma literatura quase fantástica, inverossímil, causando desconforto em seus primeiros leitores.

Como vimos em seus contos gerais, empregou ali toda a sua nova compreensão do mundo, mesclou o regional com o subjetivo, criou novos cenários e novas expectativas para esse anti-herói cardosiano, surrado pela melancolia, entregue ao fracasso e incapaz de viver plenamente sem culpa, sem dor e apagamento social. Além de usar o conto como espaço para o experimentalismo, o propalado desgosto pela imprensa ajudou a deixar essa produção inédita, intocada, por quase 70 anos. Descobrimos também que não havia unidade nos contos que chamamos de literários. O que havia, isto sim, era uma espaço para experimentar; é quando surge o mar como paisagem, é quando surgem as histórias fantásticas, os fantasmas de carne e osso, sem o toque inverossímil de suas novelas obscuras e pouco compreendidas pela crítica, a exemplo de A luz no subsolo e Mãos vazias.

Ficou evidente também que a sua produção de contos poderia ser dividida em dois blocos: o primeiro, que começa ainda na década de 1930 e se estende até o final da década de 1950, início de 1960, chamamos de os contos gerais. Foi onde ele inovou, e colocou em prática novas temáticas e concepções de tempo e espaço (sobretudo nos contos fantásticos) surpreendentes para o período. O segundo bloco tem início na década de 1950, e chamamos de contos de crime. A temática, aqui, é a vida urbana, o crime e os personagens populares das colunas de A Noite. A dedicação de Lúcio aos contos nunca foi prioridade em sua literatura. Escreveu pouco sobre eles nos Diários, se comparado às suas menções aos romances e às produções teatrais e cinematográficas. Escrevia-os para experimentar e, sobretudo, para sobreviver, pois foi de seu trabalho na imprensa que viveu nesses sete anos de "exílio romanesco". Até mesmo as novelas, gênero que empregou como poucos escritores brasileiros, foram uma espécie de atalho para chegar ao romance, e de preferência ao grande romance, à obra-prima. Lúcio acreditava que se realizaria numa única obra, escreveu contos e novelas para chegar a essa obra. Desenhou trilogias, inventou histórias sem fim que começavam em novelas e depois surgiam amiúde na imprensa no formato de conto. 
Acreditava que escrevia as histórias de crime como se estivesse sonhando. No caso dos contos de crime, os sonhos eram persecutórios e o envolviam sempre numa nuvem de culpa e incompreensão pelos seus desejos mais obscuros, como os de seus personagens criminosos e suas mulheres incestuosas, levados a cometer seus crimes por forças incontroláveis, inexplicáveis e irracionais. Desse terreno surgia a maior parte de suas narrativas - e, talvez, dessa mesma cisão vivia ele a sua própria história: um autor católico, homossexual e incompreendido, apesar do sucesso e de um grupo de admiradores confessos e presentes.

Nos contos de crime escritos para as colunas "O crime do dia" e "Novelinha do dia-a-dia" se entregou à especulação dos motivos de seus personagens planos, como os rapazes assassinos que conhecia da Lapa e da Penitenciária. Em suas histórias, acabou por levar o escritor culto, católico, para o submundo do autor mundano, e os dois - o escritor culto e o homem mundano - se encontram nas histórias escritas de supetão, tiradas da máquina de escrever sem direito a segunda leitura. Descobrimos com isto outro Lúcio Cardoso, o contista de crimes e da cidade do Rio de Janeiro, um homem que disputa com Nelson Rodrigues os palcos e um público leitor que se assemelha aos seus próprios personagens do subúrbio; um autor que frequenta as sessões de um pai de santo em Nilópolis e desloca para o seu diário suas impressões sobre a força da verdade e da persuasão que envolve os místicos.

Lúcio foi esse escritor cindido, que encontrou nessa brecha entre vida e obra, a totalidade, a certeza de que as duas andam de mãos dadas, embora a obra seja sempre maior e imposta, ao contrário da vida. E pertenceu diariamente a essa obra, mesmo quando chamado para escrever uma coluna de histórias de crime, de mortes, melancolias e de lutas passionais. Quem estava ali não era o jornalista, o narrador cronista, mas o escritor sempre em busca da obra. Com isso, não acreditou no conto como parte de sua obra, mas como passagem, como uma série de pequenas peças de uma história maior. Peças que não conseguiu reunir, talvez pela falta de tempo, pois morreu em 1968, mas sua vida literária é interrompida em 1962, com apenas 50 anos. Não acreditou em histórias que eram sonhos, ou escritas de um só jato, a ideia fixa no romance, no projeto literário contínuo, sem a serialização dos textos curtos, dos folhetins. O conto era o sonho. E o sonho se esboroa. 


\section{6 \\ Referências Bibliográficas}

6.1

\section{Obras Gerais}

ADONIAS FILHO. O romance brasileiro de 30. Rio de Janeiro: Edições Bloch, $1969,155 \mathrm{p}$.

AGAMBEN, G. Estância: a palavra e o fantasma na cultura ocidental. Belo Horizonte: Editora UFMG, 2007. 263 p.

ANDRADE, M. Aspectos da literatura brasileira. 5a ed. São Paulo: Martins, 1974.

ANDRADE, M. O Movimento Modernista. In: Aspectos da literatura brasileira. $5^{\text {a }}$ ed. São Paulo: Martins, 1974.

ANDRADE, M. Vida literária. São Paulo: Edusp/Hucitec, 1993.

ANJOS, C. dos. Criação literária. Salvador: Livraria Progresso Editora, 1959. $122 \mathrm{p}$.

ARENDT, H. Eichmann em Jerusalém: um relato sobre a banalidade do mal. São Paulo: Companhia das Letras, 1999. 336p.

ARIÈS, P. O homem diante da morte. Rio de Janeiro: Francisco Alves, 1990. (2 v.)

ARIÈS, P. Sobre a história da morte no ocidente desde a Idade Média. Lisboa: Teorema, 1989.

AYALA, W. O visível amor: diário. Rio de Janeiro: J. Álvaro, 1963. 118p.

BANDEIRA, M. Vestido de noiva. A Manhã, Rio de Janeiro, 6 de fevereiro de 1943, p. 4.

BARBOSA, A. R.; CAVALHEIRO, E. (Orgs.). Obras-primas do conto brasileiro. $3^{\text {a }}$ ed. São Paulo: Martins, 1950. 356p. 
BARKER, F. The tremulous private body: essays on subjection. Londres/Nova York: Methuen, 1984.

BATAILLE, G. Genet. In: A literatura e o mal. Porto Alegre: L\&PM, 1989.

BATAILLE, G. O erotismo. São Paulo: L\&PM, 1987.

BAUDRILLARD, J. L'echange symbolique et la mort. Sciences Humaines. Paris: Gallimard, 1976.

BAUMAN, Z. Modernidade e ambivalência. Rio de Janeiro: Jorge Zahar, 1999, 336p.

BENJAMIN, W. Obras escolhidas: magia e técnica, arte e política. São Paulo: Brasiliense, 1985.

BERGSON, H. Matéria e memória: ensaio sobre a relação do corpo com o espírito. São Paulo: Martins Fontes, 1990.

BIRMAN, J. Mal-estar na atualidade. Rio de Janeiro: Civilização Brasileira, 2007.

BLANCHOT, M. A parte do fogo. Rio de Janeiro: Rocco, 2011. 351p.

BLANCHOT, M. O espaço literário. Rio de Janeiro: Rocco, 2011. 303p.

BLEICHMAR, H. Depressão: um estudo psicanalítico. Porto Alegre: Artes Médicas, 1983.

BOSI, A. (Org.). O conto brasileiro contemporâneo. São Paulo: Cultrix, 1974. $239 \mathrm{p}$

BOSI, A. (Org.). Cultura brasileira, temas e situações. $2^{\text {a }}$ ed. São Paulo: Editora Ática, 1992. 224p.

BROWN, A. A. Death and telling in Poe's "The Imp of the Perverse". Disponível em <http://findarticles.com/p/articles/mi_m2455/ is_n2_v31/ai_15557244/1994>.

BROWN, N. Vida contra morte. Petrópolis: Vozes, 1974. 
BUENO, L. Uma história do romance de 30. São Paulo: Edusp; Campinas, Editora da Unicamp, 2006. 707p.

CACCESE, N. P. Festa. Contribuição para o estudo do modernismo. São Paulo: IEB/USP, 1971.

CALVINO, I. (Org.). Contos fantásticos do século 19. São Paulo: Companhia das Letras, 2004. 517p.

CANCINA, P. H. El dolor de existir... y la melancolía. Rosario: Homo Sapiens Ediciones, 1992.

CANDIDO, A. et al. A personagem de ficção. $11^{a}$ ed. São Paulo: Perspectiva, 2007, 119p.

CANDIDO, A. Literatura e sociedade. Rio de Janeiro: Ouro Sobre Azul, 2008. 201p.

CARDOSO, M. H. Vida Vida. Rio de Janeiro: Livraria José Olympio Editora, 1973.

CARDOSO, R. (Org.). Impresso no Brasil (1808-1930). Rio de Janeiro: Verso Brasil Editora, 2009.

CASTELlO, J. Vinicius de Moraes, o poeta da paixão: uma biografia. São Paulo: Companhia das Letras, 1994. 433p.

CASTRO, R. Ela é carioca: uma enciclopédia de Ipanema. São Paulo: Companhia das Letras, 1999. 451p.

CASTRO, R. O anjo pornográfico. A vida de Nelson Rodrigues. São Paulo: Companhia das Letras, 1997, 457p.

CAVALHEIRO, E. O conto mineiro. Rio de Janeiro: Civilização Brasileira, 1959. 339p.

CONNOR, S. Cultura pós-moderna: introdução às teorias do contemporâneo. São Paulo: Loyola, 1993.

COSTA, C. Diário Carioca, o jornal que mudou a imprensa brasileira. Rio de Janeiro: Cadernos da Biblioteca Nacional, 2001, 502p. 
COSTA, C. Pena de aluguel. Escritores jornalistas no Brasil 1904-2004. São Paulo: Companhia das Letras, 2006.

COUTINHO, E. F. Em busca da terceira margem: ensaios sobre Grande Sertão Veredas. Salvador: Fundação Casa de Jorge Amado, 1993. 100p.

CPDOC. Dicionário histórico-biográfico brasileiro pós-1930. In: ABREU, A. A. et al. Ed. ver. e atual. Rio de Janeiro: Editora FGV, 2001, vols. IV e III (GALMEL).

CRESPO, J. A história do corpo. Lisboa: Difel, 1990.

DAMASCENO, D. Poesia do sensível e do imaginário. In: MEIRELES, C. Obra Poética. Rio de Janeiro, Aguilar, 1958.

DIAS, A.; GLENADEL, P. Valores do abjeto. Niterói: EDUFF, 2008.

EDLER, S. Luto e melancolia à sombra do espetáculo. Rio de Janeiro: Civilização Brasileira, 2008, 125p.

EL FAR, A. O livro e a leitura no Brasil. Rio de Janeiro: Jorge Zahar Editor, 2006.

FERREIRA, O. da C. Imagem e letra: introdução à bibliografia brasileira. São Paulo: Edusp/Melhoramentos, 1977.

FLUSSER, V. A escrita. Há futuro para a escrita? São Paulo: Annablume, 2010, $178 \mathrm{p}$.

FLUSSER, V. Filosofia da caixa preta. São Paulo: Annablume, 2011, 107p.

FRANCA, L. Polemicas. $2^{\mathrm{a}}$ ed. Rio de Janeiro: Agir, 1953. 438p.

FRANCA, L. A crise do mundo moderno. $3^{\text {a }}$ ed. Rio de Janeiro: Agir, 1951. 248 p.

FUNDAÇÃO CASA DE RUI BARBOSA. Setor de Filologia. A crônica: o gênero, sua fixação e suas transformações no Brasil. Campinas, São Paulo/Rio de Janeiro: Ed. da UNICAMP/Fundação Casa de Rui Barbosa, 1992.

GOLDSTEIN, N. Do penumbrismo ao modernismo. São Paulo, Ática, 1983, 193p. 
GOMES, R. C. Todas as cidades, a cidade. Rio de Janeiro: Editora Rocco, 1994.

GOTLIB, N. B. Teoria do conto. 10ª ed. São Paulo: Ática, 2000. 95p.

HALLEWELL, L. O livro no Brasil: sua história. São Paulo: Edusp, 2005.

HOLLANDA, S. B. O espirito e a letra, estudos da critica literária. Vol. 1, 1920-1947. São Paulo: Companhia das Letras, 1996, 409p.

KAPLAN, A. E. O mal no pós-modernismo. Rio de Janeiro: Jorge Zahar Editor, 1993. 236p.

KRISTEVA, J. Sol negro: depressão e melancolia. Rio de Janeiro: Rocco, 1989. $231 \mathrm{p}$.

KÜBLER-ROSS, E. Sobre a morte e o morrer. São Paulo: Martins Fontes, 1991.

KUSHNIR, B. Cães de guarda: jornalistas e censores, do AI-5 à Constituição de 1988. São Paulo: Boitempo Editoral, 2004.

LAMEGO, V. Dois mil dias no deserto: Maria Helena Vieira da Silva no Rio de Janeiro (1940-1947). In: AGUILAR, N. (Org.). Vieira da Silva no Brasil. São Paulo: MAM, 2007.

LAMEGO, V. A farpa na lira: Cecília Meireles na Revolução de 30. Rio de Janeiro: Editora Record, 1996.

LIMA, H. Variações sobre o conto. Rio de Janeiro: Ministério da Educação e Saúde, Serviço de Documentação, 1952. 111p. (Os Cadernos de Cultura).

LIMA SOBRINHO, B. Os precursores. In: VÁRIOS AUTORES. Panorama do conto brasileiro. v. 1. Rio de Janeiro: Civilização Brasileira, 1959.

LISPECTOR, C. Alguns contos. Os Cadernos de Cultura. Serviço de Documentação: Ministério da Educação e Saúde, 1952.

MACHADO DE ASSIS, J. M. 50 contos. GLEDSON, J. (Org.). São Paulo: Companhia das Letras, 2007.

MACHADO DE ASSIS, J. M. Instinto de nacionalidade. O Novo Mundo, 24 de março de 1873, p. 107-108. 
MAGAlHÃES JUNIOR, R. Contos do Norte. In: VÁRIOS AUTORES, Panorama do conto brasileiro. v. 1 e 2 Rio de Janeiro: Civilização Brasileira, 1959.

MAGALHÃES JUNIOR, R. Contos do Rio de Janeiro. In: VÁRIOS AUTORES, Panorama do conto brasileiro. v. 7. Rio de Janeiro: Civilização Brasileira, 1959.

MANN, T. O escritor e sua missão (Goethe, Dostoiévski, Ibsen e outros). Rio de Janeiro: Jorge Zahar, 2011. 204p.

MARQUES, I. Cenas de um modernismo de província. São Paulo: Editora 34, 2001, 271p.

MAY, C. E. Edgar Allan Poe: a study of the short fiction. Boston: Twayne Publishers, 1991. 196p.

MERLEAU-PONTY, M. O corpo. In: __. Fenomenologia da percepção. São Paulo: Martins Fontes, 1996, p. 111-270.

MESCHONNIC, H. Modernité, modernité. Paris: Ed. Verdier, 1988.

MICELI, S. Intelectuais à brasileira. São Paulo: Companhia das Letras, 2001.

MONTEIRO, J. O conto fantástico. In: VÁRIOS AUTORES. Panorama do conto brasileiro. v. 8. Rio de Janeiro: Civilização Brasileira, 1959.

MONTEIRO, J. O conto trágico. In: VÁRIOS AUTORES. Panorama do conto brasileiro. v. 9. Rio de Janeiro: Civilização Brasileira, 1960.

MORICONI, I. (Org.). Os cem melhores contos brasileiros do século. São Paulo: Objetiva, 2009, 618p.

MORIN, E. O homem e a morte. Lisboa: Publicações Europa-América, s/d.

MOSER, B. Clarice. São Paulo: Cosac Naify, 2009.

NASCIMENTO, E. Crônica de um crime anunciado. Ipotesi: Revista de Estudos Literários. Juiz de Fora, v. 5, n. 1, 2001, p. 49-64.

NIETZCHE, F. Os pensadores. São Paulo: Abril Cultural, 1978. 416p. 
OLIVA, O. P. Corpo e mito: ensaios sobre o conto brasileiro contemporâneo. Montes Claros, MG: Unimontes, 2010. 214p.

ORNELLAS, C. P. O paciente excluído. Rio de Janeiro: Revan, 1997.

PERES, U. T. (Org.). Melancolia. São Paulo: Escuta, 1996.

PESTANA, L. F. Plano, com epígrafe. In: BUENO, Luis. Uma história do romance de 30. São Paulo: Edusp; Campinas, Editora da Unicamp, 2006.

POE, E. A. Complete tales and poems. Nova York: Dorset Press, 1989. 1092p.

POE, E. A. Eureka. São Paulo: Max Limonad, 1986. 145p.

POE, E. A. Essays and reviews. Nova York: The Library of America, 1984. $1544 p$.

POE, E. A. Contos de terror, de mistério e morte. $4^{\text {a }}$ ed. Rio de Janeiro: Nova Fronteira, 1981, 29p.

PRAZ, M. A carne, a morte e o diabo na literatura romântica. Campinas, SP: Ed. Unicamp, 1996. 473p.

PROPP, V. Morfologia do conto maravilhoso. Rio de Janeiro: ForenseUniversitária, 1984. 225p.

RAMOS, G. Linhas tortas. São Paulo: Martins Fontes, 1962.

RAYMUNDO, M. L. H. Desejo e perversão: ou os atalhos da loucura (A propósito do romance Crônica da Casa Assassinada de Lúcio Cardoso). Dissertação de Mestrado em Letras e Artes, PUC-Rio, 1974. 186fl.

REIS, M. A esquerda e a direita literária. Boletim de Ariel. Rio de Janeiro, agosto de 1935.

RIBEIRO, E. M. O riso escuro ou pavão de luto: um percurso pela poesia de Lúcio Cardoso e bibliografia anotada (1934-2005). São Paulo: Edusp/Nankim Editorial, 2006. 289p.

RODRIGUES, J. C. Tabu do corpo. Rio de Janeiro: Achiamé, 1983.

RODRIGUES, L. G. Alceu Amoroso Lima: cultura, religião e vida literária. Tese de Doutorado em Letras, Rio de Janeiro, PUC-Rio, 2009. $206 \mathrm{f}$ 
RODRIGUES, N. A vida como ela é, em 100 inéditos. Rio de Janeiro: Nova Fronteira, 2012. 434p.

RODRIGUES, N. Não tenho culpa que a vida seja como ela é. Rio de Janeiro: Agir, 2009. 256p.

SANTIAGO, S. Uma literatura nos trópicos. Rio de Janeiro: Rocco, 2000. 219 p.

SANTOS, C. Polêmica e controvérsia em Lúcio Cardoso. São Paulo: Fapesp/Mercado das Letras, 2001. 221p.

SCHUMACHER, B. Confrontos com a morte: a filosofia contemporânea e a questão da morte. Trad. Lúcia Pereira de Sousa. São Paulo: Edições Loyola, 2009. $312 \mathrm{p}$.

SCHWARTZMAN, S. e outros (Orgs.). Tempos de Capanema. São Paulo: Paz e Terra/Edusp, 1984, 388p.

SCHWARZ, R. (Org.). Os pobres na literatura brasileira. São Paulo: Brasiliense, 1983. 246p.

SENNETT, R. Carne e pedra: o corpo e a cidade na civilização ocidental. Rio de Janeiro: Record, 1997.

STEGAGNO-PICHIO, L. História da literatura brasileira. Rio de Janeiro: Academia Brasileira de Letras e Lacerda Editores, 2004.

TODOROV, T. Introdução à literatura fantástica. São Paulo: Perspectiva, 2010. 188p.

TOURAINE, A. Crítica da modernidade. Petrópolis: Vozes, 2009. 432p.

VATTIMO, G. O fim da modernidade. São Paulo: Martins Fontes, 2008. 208p.

VELHO, T. de J. P. R. A morte. Uma invariante na obra de Cornelio Penna. Dissertação de Mestrado em Letras, PUC-Rio, 1973, $121 \mathrm{f}$.

VELLOSO, M. Modernismo no Rio de Janeiro. Rio de Janeiro: FGV, 1996.

WATT, I. P. Mitos do individualismo moderno: Fausto, Dom Quixote, Don Juan, Robinson Crusoé. Rio de Janeiro: Jorge Zahar, 1997. 316p. 
WATT, I. P. The rise of the novel: Studies in Defoe, Richardson and Fielding. Middlesex: Penguin Books, 1963.333p.

\section{2}

Obras sobre Lúcio Cardoso

BEDRAN, A. M. A paixão segundo Lúcio Cardoso. In: BRANDÃO, R. S. (Org.). Lúcio Cardoso, a travessia da escrita. Belo Horizonte: Humanitas/Editora UFMG, 1998.

BRANDÃO, R. S. (Org.). Lúcio Cardoso, a travessia da escrita. Belo Horizonte: Humanitas/Editora UFMG, 1998.

BRANDÃO, R. S. Mulher ao pé da letras, a personagem feminina na literatura. Belo Horizonte: Humanitas/Editora UFMG, 2006.

CARELLI, M. Corcel de fogo: vida e obra de Lúcio Cardoso (1912-1968). Rio de Janeiro: Livraria Guanabara, 1988. 250p.

DAMASCENO, B. Lúcio Cardoso em corpo e escrita. Rio de Janeiro: Eduerj, 2012.

DAMASCENO, B. Lúcio Cardoso e a experiência-limite com o corpo e a escrita. Tese de Doutorado em Letras. PUC-Rio, 2010. $135 \mathrm{f}$

RIBEIRO, E. M. O riso escuro ou pavão de luto: um percurso pela poesia de Lúcio Cardoso e bibliografia anotada (1934-2005). São Paulo: Edusp/Nankim Editorial, 2006. 289p.

SANTOS, C. Polêmica e controvérsia em Lúcio Cardoso. São Paulo, Mercado das Letras, 2001, 22p.

\section{3}

Artigos Gerais: periódicos e jornais

AMADO, J. Maleita. O Jornal, Rio de Janeiro, 7 de outubro de 1934, $2^{\text {a }}$ Seção, 1 p.

AMADO, J. Octávio de Faria no morro do Salgueiro. A Manhã, Rio de Janeiro, 15 de junho de 1935, 3 p. 
BARBOSA, F. de A. O Imperador Jones da Bahia. Diário Carioca, Rio de Janeiro, 4 de novembro de 1935, 19 p.

BROCA, B. Da imaginação à realidade. A palavra de Lúcio Cardoso. Dom Casmurro, 9 de junho de 1938,. 2 p.

BUARQUE DE HOLLANDA, S. Um homem dentro do mundo, Diário de Notícias, Rio de Janeiro, 09 de março de 1941, capa do Letras e Artes.

FIGUEIREDO, G. Narração e introspecção. Diário de Notícias, Rio de Janeiro, 19 de dezembro de 1943, capa do Letras e Artes.

GONGORA, L. Maleita. Diário de Notícias, Rio de Janeiro, 30 de setembro de 1934, p. 18.

LIMA, H. Notas em torno do conto. A Manhã, Letras e Artes, 29 de dezembro de 1946, p. 4.

MARÇAL, H. O romance de Lúcio Cardoso. Diário de Notícias. Rio de Janeiro, $3^{\mathrm{a}}$ seção. p. 20.

MARTINS, W. Um romance brasileiro. O Estado de S. Paulo, São Paulo, 1 de agosto de 1959.

NOTA sobre contos de Lúcio Cardoso. Diário de Notícias, Rio de Janeiro, 12 de outubro de 1941, domingo, p. 18.

RAMALHETE, C. "O sapateiro e a guerra”. Diários Associados. Arquivo Lúcio Cardoso, AMLB, Fundação Casa de Rui Barbosa, s/d.

RODRIGUES, N. “Atirem a primeira pedra”, Última Hora, Rio de Janeiro, 19 de setembro de 1951, $5 \mathrm{p}$.

RODRIGUES, N. “A vida como ela é”, Última Hora, Rio de Janeiro, 17 de novembro de 1951, p.5.

SAMPAIO, N. Caminhos do espírito no Brasil hoje de Lúcio Cardoso. Diário de Notícias, Rio de janeiro, 20 de setembro de 1936, 3 p.

SCHMIDT, A. F., "Critica”, Diário de Notícias, Rio de Janeiro, 16 de dezembro de 1934. 
SOUZA DANTAS, R. "Lúcio Cardoso, jornalista", Jornal do Brasil, s/d. Arquivo Maria Helena Cardoso, Arquivo Museu Literatura Brasileira, Fundação Casa de Rui Barbosa.

\section{Notícias de jornal sem autor:}

Diário de Noticias, "O Salgueiro em polvorosa", anunciava conflito entre vários moradores após um culto religioso; homens e crianças foram feridos, houve tiroteio e correria. Rio de Janeiro, 13 de maio 1935.

A Manhã estampa a seguinte notícia na primeira capa, "Morro do Salgueiro: pedaço da Índia dos párias na 'Cidade Maravilhosa'”. Rio de Janeiro, 1935.

A Manhã, Rio de Janeiro, 10 de junho de 1950, p. 13.

\section{4 \\ Obras de Lúcio Cardoso}

\subsection{1}

Livros

CARDOSO, L. Contos da ilha e do continente. Organização de LAMEGO, V. Rio de Janeiro: Civilização Brasileira, 2012.

CARDOSO, L. Diários. Organização de RIBEIRO, E. M. Rio de Janeiro: Civilização Brasileira, 2012.

CARDOSO, L. Salgueiro. Rio de Janeiro: Civilização Brasileira, 2007. 255p.

CARDOSO, L. Dias perdidos. Rio de Janeiro: Civilização Brasileira, 2006. 404p.

CARDOSO, L. Maleita. Rio de Janeiro: Civilização Brasileira, 2005. 236p.

CARDOSO, L. Inácio, O enfeitiçado e Baltazar - Novelas. Rio de Janeiro: Civilização Brasileira, 2002. 381p.

CARDOSO, L. O desconhecido/Mãos vazias. Rio de Janeiro: Civilização Brasileira, 2000. 317p. 
CARDOSO, L. Crônica da casa assassinada. Rio de Janeiro: Civilização Brasileira, 1999. 517p.

CARDOSO, L. A luz no subsolo. Rio de Janeiro: Expressão Cultural/Instituto Nacional do Livro, 1971. 341p.

CARDOSO, L. Diário completo. Rio de Janeiro: José Olympio, 1970.

CARDOSO, L. Três histórias da cidade. Rio de Janeiro: Edições Bloch, 1969. 350p.

CARDOSO, L. Três histórias de província. Rio de Janeiro: Edições Bloch, 1969. 359p.

\section{4 .2}

Tradução

STOKER, B. Drácula: O homem da noite. [tradução de Lúcio Cardoso]. Rio de Janeiro: O Cruzeiro, 1943.

\section{5 \\ Obras de Lúcio Cardoso em Periódicos}

\subsection{1 \\ Contos Longos}

“Cantiga de roda”, O Malho, Rio de Janeiro, quinta-feira, 7 de setembro de 1933.

“Marcha fúnebre”, Literatura, Rio de Janeiro, 1933.

CARDOSO, L. Cantiga de roda. In: __. Contos da ilha e do continente. Rio de Janeiro: Civilização Brasileira, 2012, p. 35-42.

“Histórias do sertão”, Revista Acadêmica, Rio de Janeiro, n 9, 1935, p. 4.

CARDOSO, L. Histórias do sertão. In: Contos da ilha e do continente. Rio de Janeiro: Civilização Brasileira, 2012. p. 43-45. 
“A morte de Mateus”, O Jornal, Rio de Janeiro, 1938.

“O regresso", O Jornal, Rio de Janeiro, 4ª seção, domingo, 17 de abril de 1938.

“Uma criança”, Diário Carioca, Rio de Janeiro, 28 de novembro de 1938, p.23.

CARDOSO, L. O regresso. In: __. Contos da ilha e do continente. Rio de Janeiro: Civilização Brasileira, 2012, p. 46-50.

"Reminiscência”, Diário de Notícias, Rio de Janeiro, 21 de janeiro de 1940, p.8.

"Maria Emiliana", Diário de Notícias, Rio de Janeiro, 14 de abril de 1941, capa Letras e Artes.

"Um capítulo de novela inédita", A Manhã, Suplemento Literário, Rio de Janeiro, domingo, 13 de fevereiro de 1944, p. 95.

"Romance do ódio", A Manhã, Rio de Janeiro, 23 de maio de 1944, p. 4.

“Os náufragos”, A Manhã, Rio de Janeiro, sábado, 30 de setembro de 1944, p. 4.

CARDOSO, L. Os náufragos. In: Contos da ilha e do continente. Rio de Janeiro: Civilização Brasileira, 2012, p. 54-56.

CARDOSO, L. Carnaval de antigamente. In: LOUZADA, W. (Org.). Antologia de carnaval. Rio de Janeiro: O Cruzeiro, 1945, p. 351-357.

CARDOSO, L. Carnaval de antigamente. In: _. Contos da ilha e do continente. Rio de Janeiro: Civilização Brasileira, 2012, p. 57-60.

"Madrugadas", A Manhã, Letras e Artes, Rio de Janeiro, domingo, 17 de março de 1946.

CARDOSO, L. Madrugadas. In: Contos da ilha e do continente. Rio de Janeiro: Civilização Brasileira, 2012, p. 61-63.

"Junto ao mar", A Manhã, Letras e Artes, Rio de Janeiro, domingo, 5 de fevereiro de 1950, p. 13-14. Republicação de "A ilha”, A Manhã, Letras e Artes, Rio de Janeiro, $2^{\mathrm{a}}$ seção, domingo, 24 de março de 1946, p. 1, 4.

$\mathrm{Ou}$ 
"A ilha", A Manhã, Letras e Artes, Rio de Janeiro, 2a seção, domingo, 24 de março de 1946, p. 1, 4. Republicado como "Junto ao mar", A Manhã, Letras e Artes, Rio de Janeiro, domingo, 5 de fevereiro de 1950, p. 13-14.

CARDOSO, L. Junto ao mar (A ilha). In: Contos da ilha e do continente.

Rio de Janeiro: Civilização Brasileira, 2012, p. 64-69.

"O Afogado", A Manhã, Letras e Artes, Rio de Janeiro, domingo, 14 de abril de 1946, p.

CARDOSO, L. O afogado. In: __. Contos da ilha e do continente. Rio de Janeiro: Civilização Brasileira, 2012, p. 70-74.

"Simples encontro", A Manhã, Letras e Artes, Rio de Janeiro, domingo, 23 de julho de 1950, p. 9. Republicação de "A papoula azul”, A Manhã, Letras e Artes, Rio de Janeiro, domingo, 25 de agosto de 1946, p. 7.

$\mathrm{Ou}$

"A papoula azul", A Manhã, Letras e Artes, Rio de Janeiro, domingo, 25 de agosto de 1946, p. 7. Republicado como "Simples encontro", A Manhã, Letras e Artes, Rio de Janeiro, domingo, 23 de julho de 1950, p. 9.

CARDOSO, L. Simples encontro (A papoula azul). In: __. Contos da ilha e do continente. Rio de Janeiro: Civilização Brasileira, 2012. p. 75-80.

"Olhos mortos", A Manhã, Letras e Artes, Rio de Janeiro, novela publicada nos dias 2, 10 e 17 de novembro e 8 e 15 de dezembro de 1946.

CARDOSO, L. Olhos mortos. In: __ Contos da ilha e do continente. Rio de Janeiro: Civilização Brasileira, 2012. p. 81-100.

"Uma carta", A Manhã, Letras e Artes, Rio de Janeiro, domingo, 2 de fevereiro de 1947, p. 5.

"A escada", A Manhã, Letras e Artes, Rio de Janeiro, novela publicada nos dias 9 e 16 de fevereiro e 2 de março de 1947, p. 7.

CARDOSO, L. A escada. In: __. Contos da ilha e do continente. Rio de Janeiro: Civilização Brasileira, 2012. p. 109-119.

“Acontecimento", A Manhã, Letras e Artes, Rio de Janeiro, domingo, 25 de maio de 1947, p. 11. 
CARDOSO, L. Acontecimento. In: Contos da ilha e do continente. Rio de Janeiro: Civilização Brasileira, 2012. p. 120-122.

“Andorinha", A Manhã, domingo, Rio de Janeiro, 4 de abril de 1948, p. 3-4.

Republicado na Revista da Semana, Rio de Janeiro, sábado, 27 de novembro de 1954, p. 26-27.

CARDOSO, L. Andorinha. In: Contos da ilha e do continente. Rio de Janeiro: Civilização Brasileira, 2012. p. 123-131.

"Josué, o rápido", A Manhã, Letras e Artes, Rio de Janeiro, domingo, 15 de agosto de 1948.

CARDOSO, L. Josué, o rápido. In: Contos da ilha e do continente. Rio de Janeiro: Civilização Brasileira, 2012. p. 132-138.

"O viúvo", A Manhã, Letras e Artes, Rio de Janeiro, domingo, 12 de março de 1950, p. 5,12 .

CARDOSO, L. O viúvo. In: __ . Contos da ilha e do continente. Rio de Janeiro: Civilização Brasileira, 2012. p. 163-171.

"Aventura", A Manhã, Letras e Artes, Rio de Janeiro, domingo, 7 de maio de 1950, p. 5, 14-15.

CARDOSO, L. Aventura (O pátio). In: Contos da ilha e do continente. Rio de Janeiro: Civilização Brasileira, 2012. p. 101-108.

"Novela humilde (I)", A Manhã, Letras e Artes, Rio de Janeiro, domingo, 21 de maio de 1950, p. 7.

"Novela humilde (II)", A Manhã, Letras e Artes, Rio de Janeiro, domingo, 4 de junho de 1950, p. 5.

CARDOSO, L. Novela humilde. In: Contos da ilha e do continente. Rio de Janeiro: Civilização Brasileira, 2012. p. 145-155.

“Acontecimento da noite", Jornal de Letras, Rio de Janeiro, ano 2, $\mathrm{n}^{\circ} 17,1^{\circ}$ de novembro de 1950.

CARDOSO, L. Acontecimento da noite. In: CAVALHEIRO, E. (Org.). O conto mineiro. Rio de Janeiro: Civilização Brasileira, 1959, p. 273-279.

$\mathrm{Ou}$ 
"Acontecimento da noite", Jornal de Letras, Rio de Janeiro, ano 2, $\mathrm{n}^{\circ} 17,1^{\circ} \mathrm{de}$ novembro de 1950. In: CAVALHEIRO, E. (Org.). O conto mineiro. Rio de Janeiro: Civilização Brasileira, 1959, p. 273-279.

CARDOSO, L. Acontecimento da noite. In: Contos da ilha e do continente.

Rio de Janeiro: Civilização Brasileira, 2012. p. 156-162.

“Deserto”, O Jornal, Rio de Janeiro, 4ª seção, domingo, 25 de julho de 1937.

"A descoberta", O Estado de S. Paulo, Suplemento Literário, São Paulo, ano 2, $\mathrm{n}^{\mathrm{o}} 83,31$ de maio de 1958, p. 3 .

CARDOSO, L. A descoberta. In: __. Contos da ilha e do continente. Rio de Janeiro: Civilização Brasileira, 2012. p. 177-187.

\section{5 .2 \\ Artigos}

"A margem de mundos mortos", O Jornal, Rio de Janeiro, domingo, 29 de agosto de 1937 , p. $1,5$.

"Uma retificação", Dom Casmurro, Rio de Janeiro, quinta-feira, 28 de julho de 1938, p. 2.

"Sou um homem ou um monstro?", Leitura, Rio de Janeiro, n. 4, março de 1943, p. 23,35 .

“Depoimento", Dom Casmurro, Rio de Janeiro,18 de fevereiro de 1941.

“Imaginações”, Diário Carioca, Rio de Janeiro, 1944.

"A propósito de um inquérito", A Manhã, Rio de Janeiro, domingo, 7 de dezembro de 1941.

"Os romances do ódio", A Manhã, Rio de Janeiro, terça-feira, 23 de maio de 1944, p. 4.

“João Alphonsus”, A Manhã, Rio de Janeiro, quarta-feira, 31 de maio de 1944, p. 4. 
“A família Brontë”, A Manhã, Rio de Janeiro, quinta-feira, 8 de junho de 1944.

"Ala Arriba: sobre o cinema português", A Manhã, Rio de Janeiro, quarta-feira, 5 de julho de 1944.

“Edgar Poe”, A Manhã, Rio de Janeiro, quarta-feira, 12 de junho de 1944.

"Edgar Poe", A Manhã, Rio de Janeiro, quarta-feira, 18 de julho de 1944.

"Edgar Poe”, A Manhã, Rio de Janeiro, quinta-feira, 19 de julho de 1944.

“Marcier”, A Manhã, Rio de Janeiro, sábado, 5 de agosto de 1944.

“A marca", A Manhã, Rio de Janeiro, quinta-feira, 31 de agosto de 1944, p. 4.

"Três tópicos sobre literatura pós-moderna", A Manhã, Rio de Janeiro, quartafeira, 20 de setembro de 1944.

“Uma geração", A Manhã, Rio de Janeiro, domingo, 26 de maio de 1946.

"Rilkeana", tradução e seleção por Lúcio Cardoso, A Manhã, Letras e Artes, Rio de Janeiro, domingo, 16 de março de 1947, p. 13.

"Valeryana", seleção e tradução Lúcio Cardoso, A Manhã, Letras e Artes, Rio de Janeiro, domingo, 27 de abril de 1947, p. 13.

"Lawrence", A Manhã, Letras e Artes, Rio de Janeiro, domingo, 11 de maio de 1947, p. 5.

"Quase um manifesto", A Manhã, Letras e Artes, Rio de Janeiro, domingo, $1^{\circ}$ de junho de 1947 , p. 3.

"Valores", A Manhã, Letras e Artes, Rio de Janeiro, terça-feira, 8 de junho de 1948 , p. 5.

\subsection{3}

\section{Revista da Semana}

"Viagens", Revista da Semana, O Acontecimento da Semana, Rio de Janeiro, segunda-feira, 9 de outubro de 1954, p. 3. 
"Literatura de fim de ano", Revista da Semana, Rio de Janeiro, no 4, sábado, 22 de janeiro de 1955, p. 37.

"Rondó da perdição", Revista da Semana, Rio de Janeiro, nº 5, sábado, 29 de janeiro de 1955, p. 17.

"A menina morta" [resenha do romance de Cornélio Pena], Revista da Semana, Rio de Janeiro, nº 6, sábado, 5 de fevereiro de 1955, p. 41.

"Romances", Revista da Semana, Rio de Janeiro, n 7, sábado, 12 de fevereiro de 1955, p. 41.

"Homenagens", Revista da Semana, Rio de Janeiro, n 8, sábado, 19 de fevereiro de 1955 , p. 34.

"Classificações", Revista da Semana, Rio de Janeiro, no 12, sábado, 19 de março de 1955 , p. 47.

"O menino e o palacete", Revista da Semana, Rio de Janeiro, n 13, sábado, 26 de março de 1955, p. 16.

"Resumo", Revista da Semana, Rio de Janeiro, no 18, sábado, 30 de abril de 1955 , p. 37.

\section{5 .4 \\ Crônicas}

“Aldeia velha”, A Noite, Rio de Janeiro, terça-feira, 28 de julho de 1953, crônica, p. 10.

"Da passagem", A Noite, Rio de Janeiro, quinta-feira, 30 de julho de 1953, crônica, p. 2.

“Do mar”, A Noite, Rio de Janeiro, sexta-feira, 31 de julho de 1953, crônica, p. 2.

"A propósito de inquéritos", A Noite, Rio de Janeiro, segunda-feira, 3 de agosto de 1953, crônica, p. 2.

"Um romancista americano", A Noite, Rio de Janeiro, quarta-feira, 5 de agosto de 1953, [crônica], p. 9 
"Luiza e o teatro", A Noite, Rio de Janeiro, sexta-feira, 14 de agosto de 1953, crônica, p. 9.

\subsection{5 \\ Exertos}

"Confissão", Lanterna Verde: Boletim da Sociedade Felippe D'Oliveira, Rio de Janeiro, fevereiro de 1935. In: CARDOSO, L. Salgueiro. Rio de Janeiro: José Olympio, 1935. Trecho inédito de Céu escuro.

"Um capitulo de romance", Diário de Notícias, Rio de Janeiro, 24 de novembro de 1940.

"Reaparição de Inácio", A Manhã, Letras e Artes, Rio de Janeiro, 2ª seção, no 11, domingo, 11 de agosto de 1946, p. 5. In: CARDOSO, L. O enfeitiçado. Rio de Janeiro: Civilização Brasileira, 2002.

"Solilóquio de um solitário", A Manhã, Letras e Artes, Rio de Janeiro, 2 ${ }^{\mathrm{a}}$ seção, $\mathrm{n}^{\circ}$ 82, quinta-feira, 18 de abril de 1948, p. 5. In: CARDOSO, L. O enfeitiçado. Rio de Janeiro: Civilização Brasileira, 2002, p. 196.

"O delírio", A Manhã, Letras e Artes, Rio de Janeiro, domingo, 19 de março de 1950, p. 13. In: CARDOSO, L. Baltazar. Rio de Janeiro: Civilização Brasileira, 2002, p. 157-159.

"Bazilio da Luz", A Manhã, Letras e Artes, Rio de Janeiro, domingo, 16 de abril de 1950. Continuação de "O delírio", A Manhã, Rio de Janeiro, Letras e Artes, domingo, 19 de março de 1950, p. 13.

CARDOSO, L. Basílio da Luz. In: Contos da ilha e do continente. Rio de Janeiro: Civilização Brasileira, 2012, p. 139-144.

"Capítulo de romance", A Manhã, Letras e Artes, Rio de Janeiro, domingo, 14 de maio de 1950, p. 7. In: CARDOSO, L. Baltazar. Rio de Janeiro: Civilização Brasileira, 2002. p. 157-159.

"A cartomante", A Manhã, Letras e Artes, Rio de Janeiro, domingo, 13 de agosto de 1950, p. 5. In: CARDOSO, L. Baltazar. Rio de Janeiro: Civilização Brasileira, 2002, p. 157-159.

"Flora", A Manhã, Literatura e Artes, Rio de Janeiro, domingo, 8 de outubro de 1950, p. 4. In: CARDOSO, L. Baltazar. Rio de Janeiro: Civilização Brasileira, 2002. p. 157-159. 
“O açude", A Manhã, Rio de Janeiro, sábado, 25 de novembro de 1944, p. 4. In: CARDOSO, L. A professora Hilda. Rio de Janeiro: José Olympio, 1946.

"Diante do rio", A Manhã, Rio de Janeiro, sábado, 21 de outubro de 1944, p. 4. In: CARDOSO, L. Céu escuro. Rio de Janeiro: A Noite, 1940.

CARDOSO, L. Diante do rio. In: Contos da ilha e do continente. Rio de Janeiro: Civilização Brasileira, 2012, p. 236-239.

"História de Cristiana (I)", A Manhã, Rio de Janeiro, sábado, 28 de outubro de 1944, p. 4. In: CARDOSO, L. Céu escuro. Rio de Janeiro: A Noite, 1940.

CARDOSO, Lúcio. História de Cristiana (1). In: Contos da ilha e do continente. Rio de Janeiro: Civilização Brasileira, 2012, p. 240-243.

"História de Cristiana (II)", A Manhã, Rio de Janeiro, sábado, 28 de outubro de 1944, p. 4. In: CARDOSO, Lúcio. Céu escuro. Rio de Janeiro: A Noite, 1940.

CARDOSO, Lúcio. História de Cristiana (2). In: __. Contos da ilha e do continente. Rio de Janeiro: Civilização Brasileira, 2012, p. 244-247.

"A professora Hilda", A Manhã, Rio de Janeiro, quarta-feira, 23 de agosto de 1944, p. 4. In: CARDOSO, L. A professora Hilda. Rio de Janeiro: José Olympio, 1946.

\subsection{6 \\ "O Crime do Dia"}

\section{ABRIL DE 1952}

"O Crime do Dia: Lúcio Cardoso, brilhante escritor, um novo companheiro de trabalho", A Noite, Rio de Janeiro, quarta-feira, 2 de abril de 1952, p. 1. [Continua na p. 12].

“Assassínio por engano", A Noite, seção Risos e Lágrimas da Cidade, O Crime do Dia, Rio de Janeiro, quarta-feira, 2 de abril de 1952, p. 12.

"O homem de duas caras", A Noite, seção Risos e Lágrimas da Cidade, O Crime do Dia, Rio de Janeiro, quinta-feira, 3 de abril de 1952, p. 7.

"O homem de preto", A Noite, seção Risos e Lágrimas da Cidade, O Crime do Dia, Rio de Janeiro, sexta-feira, 4 de abril de 1952, p. 13. 
"História de malandro", A Noite, seção Risos e Lágrimas da Cidade, O Crime do Dia, Rio de Janeiro, sábado, 5 de abril de 1952, p. 11.

*Observação: A partir daqui não aparece mais "O Crime do Dia" na página em que o conto é publicado.

"Um caso banal", A Noite, seção Risos e Lágrimas da Cidade, O Crime do Dia, Rio de Janeiro, segunda-feira, 7 de abril de 1952, p. 6.

"Azar", A Noite, seção Risos e Lágrimas da Cidade, O Crime do Dia, Rio de Janeiro, terça-feira, 8 de abril de 1952, p. 9.

"O crime da praia", A Noite, seção Risos e Lágrimas da Cidade, O Crime do Dia, Rio de Janeiro, quarta-feira, 9 de abril de 1952, p. 9.

"O monstro de olhos verdes", A Noite, seção Risos e Lágrimas da Cidade, O Crime do Dia, Rio de Janeiro, quinta-feira, 10 de abril de 1952, p. 9.

"A mulher de Caruaru", A Noite, seção Risos e Lágrimas da Cidade, O Crime do Dia, Rio de Janeiro, sábado, 12 de abril de 1952, p. 9.

"A volta do baiano", A Noite, seção Risos e Lágrimas da Cidade, O Crime do Dia, Rio de Janeiro, segunda-feira, 14 de abril de 1952, p. 7.

“A mulher alugada", A Noite, seção Risos e Lágrimas da Cidade, O Crime do Dia, Rio de Janeiro, terça-feira, 15 de abril de 1952, p. 9.

"A dama do lago", A Noite, seção Risos e Lágrimas da Cidade, O Crime do Dia, Rio de Janeiro, quarta-feira, 16 de abril de 1952, p. 9.

"A gata amarela", A Noite, seção Risos e Lágrimas da Cidade, O Crime do Dia, Rio de Janeiro, quinta-feira, 17 de abril de 1952, p. 9.

"A vidente de São Cristóvão", A Noite, seção Risos e Lágrimas da Cidade, O Crime do Dia, Rio de Janeiro, sexta-feira, 18 de abril de 1952, p. 8.

"Um homem de sorte", A Noite, seção Risos e Lágrimas da Cidade, O Crime do Dia, Rio de Janeiro, sábado, 19 de abril de 1952, p. 10.

"O marido desconfiado", A Noite, seção Risos e Lágrimas da Cidade, O Crime do Dia, Rio de Janeiro, terça-feira, 22 de abril de 1952, p. 9. 
"O vestido de baile", A Noite, seção Risos e Lágrimas da Cidade, O Crime do Dia, Rio de Janeiro, quarta-feira, 23 de abril de 1952, p. 9.

"Um retrato", A Noite, seção Risos e Lágrimas da Cidade, O Crime do Dia, Rio de Janeiro, quinta-feira, 24 de abril de 1952, p. 10.

"O duplo crime", A Noite, seção Risos e Lágrimas da Cidade, O Crime do Dia, Rio de Janeiro, sexta-feira, 25 de abril de 1952, p. 6.

"O pássaro da madrugada", A Noite, seção Risos e Lágrimas da Cidade, O Crime do Dia, Rio de Janeiro, sábado, 26 de abril de 1952, p. 13.

"Fábula do falso assassino", A Noite, seção Risos e Lágrimas da Cidade, O Crime do Dia, Rio de Janeiro, segunda-feira, 28 de abril de 1952, p. 7.

"Fábula do advogado vaidoso", A Noite, seção Risos e Lágrimas da Cidade, O Crime do Dia, Rio de Janeiro, terça-feira, 29 de abril de 1952, p. 10.

"O prisioneiro", A Noite, seção Risos e Lágrimas da Cidade, O Crime do Dia, Rio de Janeiro, quarta-feira, 30 de abril de 1952, p. 6.

\section{MAIO DE 1952}

"O amante", A Noite, seção Risos e Lágrimas da Cidade, O Crime do Dia, Rio de Janeiro, sexta-feira, 2 de maio de 1952, p. 9.

"A mentirosa", A Noite, seção Risos e Lágrimas da Cidade, O Crime do Dia, Rio de Janeiro, sábado, 3 de maio de 1952, p. 9.

"Ninho de amores", A Noite, seção Risos e Lágrimas da Cidade, O Crime do Dia, Rio de Janeiro, segunda-feira, 5 de maio de 1952, p. 4.

"Cândida", A Noite, seção Risos e Lágrimas da Cidade, O Crime do Dia, Rio de Janeiro, terça-feira, 6 de maio de 1952, p. 6.

"Vargem Grande", A Noite, seção Risos e Lágrimas da Cidade, O Crime do Dia, Rio de Janeiro, quarta-feira, 7 de maio de 1952, p. 9.

"Titia", A Noite, seção Risos e Lágrimas da Cidade, O Crime do Dia, Rio de Janeiro, quinta-feira, 8 de maio de 1952, p. 11. 
"O crime do alfaiate", A Noite, seção Risos e Lágrimas da Cidade, O Crime do Dia, Rio de Janeiro, sexta-feira, 9 de maio de 1952, p. 6.

"Wanda", A Noite, seção Risos e Lágrimas da Cidade, O Crime do Dia, Rio de Janeiro, sábado, 10 de maio de 1952, p. 9.

"Leontina", A Noite, seção Risos e Lágrimas da Cidade, O Crime do Dia, Rio de Janeiro, terça-feira, 13 de maio de 1952, p. 9.

"O preço", A Noite, seção Risos e Lágrimas da Cidade, O Crime do Dia, Rio de Janeiro, quarta-feira, 14 de maio de 1952, p. 9.

“A viagem”, A Noite, seção Risos e Lágrimas da Cidade, O Crime do Dia, Rio de Janeiro, quinta-feira, 15 de maio de 1952, p. 6.

"Ai, Catarina", A Noite, seção Risos e Lágrimas da Cidade, O Crime do Dia, Rio de Janeiro, sexta-feira, 16 de maio de 1952, p. 6.

"O poço", A Noite, seção Risos e Lágrimas da Cidade, O Crime do Dia, Rio de Janeiro, sábado, 17 de maio de 1952, p. 10.

"As duas irmãs", A Noite, seção Risos e Lágrimas da Cidade, O Crime do Dia, Rio de Janeiro, segunda-feira, 19 de maio de 1952, p. 6.

"O sedutor", A Noite, seção Risos e Lágrimas da Cidade, O Crime do Dia, Rio de Janeiro, terça-feira, 20 de maio de 1952, p. 9.

"A fuga", A Noite, seção Risos e Lágrimas da Cidade, O Crime do Dia, Rio de Janeiro, quarta-feira, 21 de maio de 1952, p. 11.

"O véu", A Noite, seção Risos e Lágrimas da Cidade, O Crime do Dia, Rio de Janeiro, quinta-feira, 22 de maio de 1952, p. 9.

“A prova”, A Noite, seção Risos e Lágrimas da Cidade, O Crime do Dia, Rio de Janeiro, sexta-feira, 23 de maio de 1952, p. 12.

"O crime da lancha", A Noite, seção Risos e Lágrimas da Cidade, O Crime do Dia, Rio de Janeiro, sábado, 24 de maio de 1952, p. 11.

"Um amor", A Noite, seção Risos e Lágrimas da Cidade, O Crime do Dia, Rio de Janeiro, segunda-feira, 26 de maio de 1952, p. 6. 
"O juramento", A Noite, seção Risos e Lágrimas da Cidade, O Crime do Dia, Rio de Janeiro, terça-feira, 27 de maio de 1952, p. 9.

"Criança", A Noite, seção Risos e Lágrimas da Cidade, O Crime do Dia, Rio de Janeiro, quarta-feira, 28 de maio de 1952, p. 11.

"Barco à vela", A Noite, seção Risos e Lágrimas da Cidade, O Crime do Dia, Rio de Janeiro, quinta-feira, 29 de maio de 1952, p. 9.

* Observação: A partir deste dia, os contos passam para o canto esquerdo da página, num box de folha inteira. Até então, os contos eram publicados sob o cabeçalho "Risos e Lágrimas da Cidade".

"Celeste", A Noite, seção Risos e Lágrimas da Cidade, O Crime do Dia, Rio de Janeiro, sexta-feira, 30 de maio de 1952, p. 9.

"Leontina", A Noite, seção Risos e Lágrimas da Cidade, O Crime do Dia, Rio de Janeiro, sábado, 31 de maio de 1952, p. 9.

\section{JUNHO DE 1952}

"Marinheiro", A Noite, seção Risos e Lágrimas da Cidade, O Crime do Dia, Rio de Janeiro, segunda-feira, 2 de junho de 1952, p. 7.

“As joias", A Noite, seção Risos e Lágrimas da Cidade, O Crime do Dia, Rio de Janeiro, terça-feira, 3 de junho de 1952, p. 9.

"O lírio", A Noite, seção Risos e Lágrimas da Cidade, O Crime do Dia, Rio de Janeiro, quarta-feira, 4 de junho de 1952, p. 9.

"Lena", A Noite, seção Risos e Lágrimas da Cidade, O Crime do Dia, Rio de Janeiro, quinta-feira, 5 de junho de 1952, p. 14.

"O passageiro", A Noite, seção Risos e Lágrimas da Cidade, O Crime do Dia, Rio de Janeiro, sexta-feira, 6 de junho de 1952, p. 11.

"Adolescente", A Noite, seção Risos e Lágrimas da Cidade, O Crime do Dia, Rio de Janeiro, segunda-feira, 9 de junho de 1952, p. 6.

"Um caso banal", A Noite, seção Risos e Lágrimas da Cidade, O Crime do Dia, Rio de Janeiro, terça-feira, 10 de junho de 1952, p. 9.

"Pecado", A Noite, seção Risos e Lágrimas da Cidade, O Crime do Dia, Rio de Janeiro, quarta-feira, 11 de junho de 1952, p. 11. 
"Enfermeira", A Noite, seção Risos e Lágrimas da Cidade, O Crime do Dia, Rio de Janeiro, sexta-feira, 13 de junho de 1952, p. 13.

"Fotógrafo", A Noite, seção Risos e Lágrimas da Cidade, O Crime do Dia, Rio de Janeiro, sábado, 14 de junho de 1952, p. 9.

"O profanador", A Noite, seção Risos e Lágrimas da Cidade, O Crime do Dia, Rio de Janeiro, segunda-feira, 16 de junho de 1952, p. 5.

“A amiga”, A Noite, seção Risos e Lágrimas da Cidade, O Crime do Dia, Rio de Janeiro, terça-feira, 17 de junho de 1952, p. 11.

"Fabião", A Noite, seção Risos e Lágrimas da Cidade, O Crime do Dia, Rio de Janeiro, quarta-feira, 18 de junho de 1952, p. 11.

"Sem crime", A Noite, seção Risos e Lágrimas da Cidade, O Crime do Dia, Rio de Janeiro, quinta-feira, 19 de junho de 1952, p. 9.

"Crime no ermo", A Noite, seção Risos e Lágrimas da Cidade, O Crime do Dia, Rio de Janeiro, sexta-feira, 20 de junho de 1952, p. 11.

"Playground", A Noite, seção Risos e Lágrimas da Cidade, O Crime do Dia, Rio de Janeiro, sábado, 21 de junho de 1952, p. 9.

"A professora", A Noite, seção Risos e Lágrimas da Cidade, O Crime do Dia, Rio de Janeiro, segunda-feira, 23 de junho de 1952, p. 7.

"O pacto", A Noite, seção Risos e Lágrimas da Cidade, O Crime do Dia, Rio de Janeiro, terça-feira, 24 de junho de 1952, p. 11.

"Carta”, A Noite, seção Risos e Lágrimas da Cidade, O Crime do Dia, Rio de Janeiro, quarta-feira, 25 de junho de 1952, p. 11.

"Dúvida...”, A Noite, seção Risos e Lágrimas da Cidade, O Crime do Dia, Rio de Janeiro, sexta-feira, 27 de junho de 1952, p. 6.

"A sedutora", A Noite, seção Risos e Lágrimas da Cidade, O Crime do Dia, Rio de Janeiro, sábado, 28 de junho de 1952, p. 11.

"Nancy", A Noite, seção Risos e Lágrimas da Cidade, O Crime do Dia, Rio de Janeiro, segunda-feira, 30 de junho de 1952, p. 6. 


\section{JULHO DE 1952}

"Feitiço", A Noite, seção Risos e Lágrimas da Cidade, O Crime do Dia, Rio de Janeiro, terça-feira, $1^{\underline{0}}$ de julho de 1952, p. 9.

"Gaivota", A Noite, seção Risos e Lágrimas da Cidade, O Crime do Dia, Rio de Janeiro, quarta-feira, 2 de julho de 1952, p. 11.

"A venda", A Noite, seção Risos e Lágrimas da Cidade, O Crime do Dia, Rio de Janeiro, quinta-feira, 3 de julho de 1952, p. 9.

"Perseguição", A Noite, seção Risos e Lágrimas da Cidade, O Crime do Dia, Rio de Janeiro, sexta-feira, 4 de julho de 1952, p. 8.

"A casa do crime", A Noite, seção Risos e Lágrimas da Cidade, O Crime do Dia, Rio de Janeiro, sábado, 5 de julho de 1952, p. 9.

"A caldeira", A Noite, seção Risos e Lágrimas da Cidade, O Crime do Dia, Rio de Janeiro, quarta-feira, 9 de julho de 1952, p. 9.

"Os alfinetes de prata", A Noite, seção Risos e Lágrimas da Cidade, O Crime do Dia, Rio de Janeiro, quinta-feira, 10 de julho de 1952, p. 11.

"Menino de ouro", A Noite, seção Risos e Lágrimas da Cidade, O Crime do Dia, Rio de Janeiro, sexta-feira, 11 de julho de 1952, p. 9.

"A casa", A Noite, seção Risos e Lágrimas da Cidade, O Crime do Dia, Rio de Janeiro, sábado, 12 de julho de 1952, p. 9.

"Depois do velório", A Noite, seção Risos e Lágrimas da Cidade, O Crime do Dia, Rio de Janeiro, segunda-feira, 14 de julho de 1952, p. 6.

“Além da floresta”, A Noite, seção Risos e Lágrimas da Cidade, O Crime do Dia, Rio de Janeiro, terça-feira, 15 de julho de 1952, p. 11.

"A volta", A Noite, seção Risos e Lágrimas da Cidade, O Crime do Dia, Rio de Janeiro, quarta-feira, 16 de julho de 1952, p. 9.

"Isaura", A Noite, seção Risos e Lágrimas da Cidade, O Crime do Dia, Rio de Janeiro, quinta-feira, 17 de julho de 1952, p. 9.

"Madame", A Noite, seção Risos e Lágrimas da Cidade, O Crime do Dia, Rio de Janeiro, sexta-feira, 18 de julho de 1952, p. 9. 
"O sósia”, A Noite, seção Risos e Lágrimas da Cidade, O Crime do Dia, Rio de Janeiro, sábado, 19 de julho de 1952, p. 6.

"Aparecida", A Noite, seção Risos e Lágrimas da Cidade, O Crime do Dia, Rio de Janeiro, segunda-feira, 21 de julho de 1952, $2^{\text {a }}$ seção, p. 7.

"O assassino", A Noite, seção Risos e Lágrimas da Cidade, O Crime do Dia, Rio de Janeiro, terça-feira, 22 de julho de 1952, p. 11.

"A carta anônima", A Noite, seção Risos e Lágrimas da Cidade, O Crime do Dia, Rio de Janeiro, quarta-feira, 23 de julho de 1952, p. 11.

"Geraldo feião", A Noite, seção Risos e Lágrimas da Cidade, O Crime do Dia, Rio de Janeiro, quinta-feira, 24 de julho de 1952, p. 6.

"Lulú", A Noite, seção Risos e Lágrimas da Cidade, O Crime do Dia, Rio de Janeiro, sexta-feira, 25 de Julho de 1952, p. 7.

"O discípulo", A Noite, seção Risos e Lágrimas da Cidade, O Crime do Dia, Rio de Janeiro, sábado, 26 de julho de 1952, p. 9.

"Uma história comum", A Noite, seção Risos e Lágrimas da Cidade, O Crime do Dia, Rio de Janeiro, segunda-feira, 28 de julho de 1952, $2^{\text {a }}$ seção, p. 5.

"Ciganos", A Noite, seção Risos e Lágrimas da Cidade, O Crime do Dia, Rio de Janeiro, terça-feira, 29 de julho de 1952, p. 9.

"Sete filhos", A Noite, seção Risos e Lágrimas da Cidade, O Crime do Dia, Rio de Janeiro, quarta-feira, 30 de julho de 1952, p. 11.

"O noivo", A Noite, seção Risos e Lágrimas da Cidade, O Crime do Dia, Rio de Janeiro, quinta-feira, 31 de julho de 1952, p. 9.

\section{AGOSTO DE 1952}

"Janine", A Noite, seção Risos e Lágrimas da Cidade, O Crime do Dia, Rio de Janeiro, sexta-feira, $1^{\circ}$ de agosto de 1952, p. 7.

"O curandeiro", A Noite, seção Risos e Lágrimas da Cidade, O Crime do Dia, Rio de Janeiro, sábado, 2 de agosto de 1952, p. 11. 
"Comédia urbana", A Noite, seção Risos e Lágrimas da Cidade, O Crime do Dia, Rio de Janeiro, terça-feira, 5 de agosto de 1952, p. 11.

“A prisioneira", A Noite, seção Risos e Lágrimas da Cidade, O Crime do Dia, Rio de Janeiro, quarta-feira, 6 de agosto de 1952, p. 11.

“Amor", A Noite, seção Risos e Lágrimas da Cidade, O Crime do Dia, Rio de Janeiro, quinta-feira, 7 de agosto de 1952, p. 9.

"Sorte", A Noite, seção Risos e Lágrimas da Cidade, O Crime do Dia, Rio de Janeiro, sexta-feira, 8 de agosto de 1952, p. 11.

"Circo", A Noite, seção Risos e Lágrimas da Cidade, O Crime do Dia, Rio de Janeiro, sábado, 9 de agosto de 1952, p. 9.

"Noiva", A Noite, seção Risos e Lágrimas da Cidade, O Crime do Dia, Rio de Janeiro, terça-feira, 12 de agosto de 1952, p. 9.

"Aventura", A Noite, seção Risos e Lágrimas da Cidade, O Crime do Dia, Rio de Janeiro, quarta-feira, 13 de agosto de 1952, p. 11.

"Alucinação", A Noite, seção Risos e Lágrimas da Cidade, O Crime do Dia, Rio de Janeiro, quinta-feira, 14 de agosto de 1952, p. 9.

"O porão", A Noite, seção Risos e Lágrimas da Cidade, O Crime do Dia, Rio de Janeiro, sexta-feira, 15 de agosto de 1952, p. 13.

"O açougue", A Noite, seção Risos e Lágrimas da Cidade, O Crime do Dia, Rio de Janeiro, sábado, 16 de agosto de 1952, p. 11.

"Dolores", A Noite, seção Risos e Lágrimas da Cidade, O Crime do Dia, Rio de Janeiro, terça-feira, 19 de agosto de 1952, p. 9.

"Dois crimes", A Noite, seção Risos e Lágrimas da Cidade, O Crime do Dia, Rio de Janeiro, quarta-feira, 20 de agosto de 1952, p. 11.

"Um cavalo", A Noite, seção Risos e Lágrimas da Cidade, O Crime do Dia, Rio de Janeiro, quinta-feira, 21 de agosto de 1952, p. 11.

"A lua", A Noite, seção Risos e Lágrimas da Cidade, O Crime do Dia, Rio de Janeiro, sexta-feira, 22 de agosto de 1952, p. 7. 
"Matilde", A Noite, seção Risos e Lágrimas da Cidade, O Crime do Dia, Rio de Janeiro, sábado, 23 de agosto de 1952, p. 11.

"Azul e branco", A Noite, seção Risos e Lágrimas da Cidade, O Crime do Dia, Rio de Janeiro, terça-feira, 26 de agosto de 1952, p. 11.

"A dama de luto", A Noite, seção Risos e Lágrimas da Cidade, O Crime do Dia, Rio de Janeiro, quarta-feira, 27 de agosto de 1952, p. 11.

"Um dia", A Noite, seção Risos e Lágrimas da Cidade, O Crime do Dia, Rio de Janeiro, quinta-feira, 28 de agosto de 1952, p. 9.

"A casa", A Noite, seção Risos e Lágrimas da Cidade, O Crime do Dia, Rio de Janeiro, sexta-feira, 29 de agosto de 1952, p. 4.

"Egito", A Noite, seção Risos e Lágrimas da Cidade, O Crime do Dia, Rio de Janeiro, sábado, 30 de agosto de 1952, p. 9.

\section{SETEMBRO DE 1952}

"O forno", A Noite, seção Risos e Lágrimas da Cidade, O Crime do Dia, Rio de Janeiro, quarta-feira, 3 de setembro de 1952, p. 11.

"Mentirosa", A Noite, seção Risos e Lágrimas da Cidade, O Crime do Dia, Rio de Janeiro, quinta-feira, 4 de setembro de 1952, p. 11.

"Luisinha", A Noite, seção Risos e Lágrimas da Cidade, O Crime do Dia, Rio de Janeiro, sexta-feira, 5 de setembro de 1952, p. 7.

"Izidoro", A Noite, seção Risos e Lágrimas da Cidade, O Crime do Dia, Rio de Janeiro, sábado, 6 de setembro de 1952, p. 11.

"Paquetá", A Noite, seção Risos e Lágrimas da Cidade, O Crime do Dia, Rio de Janeiro, quarta-feira, 10 de setembro de 1952, p. 11.

“Acontecimento", A Noite, seção Risos e Lágrimas da Cidade, O Crime do Dia, Rio de Janeiro, quinta-feira, 11 de setembro de 1952, p. 11.

"Homem do bar", A Noite, seção Risos e Lágrimas da Cidade, O Crime do Dia, Rio de Janeiro, sexta-feira, 12 de setembro de 1952, p. 7. 
"O automóvel”, A Noite, seção Risos e Lágrimas da Cidade, O Crime do Dia, Rio de Janeiro, sábado, 13 de setembro de 1952, p. 9.

"Triângulo", A Noite, seção Risos e Lágrimas da Cidade, O Crime do Dia, Rio de Janeiro, segunda-feira, 15 de setembro de 1952, p. 7.

"A troca", A Noite, seção Risos e Lágrimas da Cidade, O Crime do Dia, Rio de Janeiro, terça-feira, 16 de setembro de 1952, p. 11.

"As afilhadas", A Noite, seção Risos e Lágrimas da Cidade, O Crime do Dia, Rio de Janeiro, quinta-feira, 18 de setembro de 1952, p. 11.

"O acompanhante", A Noite, seção Risos e Lágrimas da Cidade, O Crime do Dia, Rio de Janeiro, sexta-feira, 19 de setembro de 1952, p. 7.

"O amolador", A Noite, seção Risos e Lágrimas da Cidade, O Crime do Dia, Rio de Janeiro, sábado, 20 de setembro de 1952, p. 9.

"Confissão", A Noite, seção Risos e Lágrimas da Cidade, O Crime do Dia, Rio de Janeiro, terça-feira, 23 de setembro de 1952, p. 9.

"O tesouro", A Noite, seção Risos e Lágrimas da Cidade, O Crime do Dia, Rio de Janeiro, quarta-feira, 24 de setembro de 1952, p. 13.

"Abandonada", A Noite, seção Risos e Lágrimas da Cidade, O Crime do Dia, Rio de Janeiro, quinta-feira, 25 de setembro de 1952, p. 9.

"Orfanato", A Noite, seção Risos e Lágrimas da Cidade, O Crime do Dia, Rio de Janeiro, sexta-feira, 26 de setembro de 1952, p. 11.

"A festa", A Noite, seção Risos e Lágrimas da Cidade, O Crime do Dia, Rio de Janeiro, sábado, 27 de setembro de 1952, p. 7.

"O erro", A Noite, seção Risos e Lágrimas da Cidade, O Crime do Dia, Rio de Janeiro, terça-feira, 30 de setembro de 1952, p. 9.

\section{OUTUBRO DE 1952}

“Assalto", A Noite, seção Risos e Lágrimas da Cidade, O Crime do Dia, Rio de Janeiro, quarta-feira, $1^{\circ}$ de outubro de 1952, p. 9. 
"O artista”, A Noite, seção Risos e Lágrimas da Cidade, O Crime do Dia, Rio de Janeiro, quinta-feira, 2 de outubro de 1952, p. 11.

"Um inferno", A Noite, seção Risos e Lágrimas da Cidade, O Crime do Dia, Rio de Janeiro, sexta-feira, 3 de outubro de 1952, p. 7

"O pasteleiro", A Noite, seção Risos e Lágrimas da Cidade, O Crime do Dia, Rio de Janeiro, terça-feira, 7 de outubro de 1952, p. 11.

"O inventor", A Noite, seção Risos e Lágrimas da Cidade, O Crime do Dia, Rio de Janeiro, quarta-feira, 8 de outubro de 1952, p. 9.

"Militão", A Noite, seção Risos e Lágrimas da Cidade, O Crime do Dia, Rio de Janeiro, quinta-feira, 9 de outubro de 1952, p. 11.

"Carolina", A Noite, seção Risos e Lágrimas da Cidade, O Crime do Dia, Rio de Janeiro, sexta-feira, 10 de outubro de 1952, p. 9.

"O banho", A Noite, seção Risos e Lágrimas da Cidade, O Crime do Dia, Rio de Janeiro, sábado, 11 de outubro de 1952, p. 9.

"Piquenique", A Noite, seção Risos e Lágrimas da Cidade, O Crime do Dia, Rio de Janeiro, quarta-feira, 15 de outubro de 1952, p. 9.

"Culpada", A Noite, seção Risos e Lágrimas da Cidade, O Crime do Dia, Rio de Janeiro, quinta-feira, 16 de outubro de 1952, p. 11.

"O porteiro noturno", A Noite, seção Risos e Lágrimas da Cidade, O Crime do Dia, Rio de Janeiro, sexta-feira, 17 de outubro de 1952, p. 7.

“O caluniador", A Noite, seção Risos e Lágrimas da Cidade, O Crime do Dia, Rio de Janeiro, sábado, 18 de outubro de 1952, p. 9.

“O explorador", A Noite, seção Risos e Lágrimas da Cidade, O Crime do Dia, Rio de Janeiro, terça-feira, 21 de outubro de 1952, p. 9.

"O duplo crime", A Noite, seção Risos e Lágrimas da Cidade, O Crime do Dia, Rio de Janeiro, quarta-feira, 22 de outubro de 1952, p. 9.

"Um crime", A Noite, seção Risos e Lágrimas da Cidade, O Crime do Dia, Rio de Janeiro, quinta-feira, 23 de outubro de 1952, p. 11. 
"A testemunha", A Noite, seção Risos e Lágrimas da Cidade, O Crime do Dia, Rio de Janeiro, sexta-feira, 24 de outubro de 1952, p. 9.

“Caso doméstico”, A Noite, Rio de Janeiro, sábado, 25 de outubro de 1952, p. 9.

"Um tempo", A Noite, seção Risos e Lágrimas da Cidade, O Crime do Dia, Rio de Janeiro, quarta-feira, 29 de outubro de 1952, p. 7.

"Delito", A Noite, seção Risos e Lágrimas da Cidade, O Crime do Dia, Rio de Janeiro, quinta-feira, 30 de outubro de 1952, p. 11.

"A rainha", A Noite, seção Risos e Lágrimas da Cidade, O Crime do Dia, Rio de Janeiro, sexta-feira, 31 de outubro de 1952, p. 9.

\section{NOVEMBRO DE 1952}

"Pastoral", A Noite, seção Risos e Lágrimas da Cidade, O Crime do Dia, Rio de Janeiro, sábado, $1^{\circ}$ de novembro de 1952, p. 9.

"Eponina", A Noite, seção Risos e Lágrimas da Cidade, O Crime do Dia, Rio de Janeiro, quarta-feira, 5 de novembro de 1952, p. 11.

"Crepúsculo", A Noite, seção Risos e Lágrimas da Cidade, O Crime do Dia, Rio de Janeiro, quinta-feira, 6 de novembro de 1952, p. 7.

"Um golpe", A Noite, seção Risos e Lágrimas da Cidade, O Crime do Dia, Rio de Janeiro, sexta-feira, 7 de novembro de 1952, p. 9.

"Dona Paula", A Noite, seção Risos e Lágrimas da Cidade, O Crime do Dia, Rio de Janeiro, sábado, 8 de novembro de 1952, p. 9.

"Segredo", A Noite, seção Risos e Lágrimas da Cidade, O Crime do Dia, Rio de Janeiro, quarta-feira, 12 de novembro de 1952, p. 11.

"Sanatório", A Noite, seção Risos e Lágrimas da Cidade, O Crime do Dia, Rio de Janeiro, quinta-feira, 13 de novembro de 1952, p. 11.

"O craque", A Noite, seção Risos e Lágrimas da Cidade, O Crime do Dia, Rio de Janeiro, sexta-feira, 14 de novembro de 1952, p. 9.

"O achado", A Noite, seção Risos e Lágrimas da Cidade, O Crime do Dia, Rio de Janeiro, sábado, 15 de novembro de 1952, p. 11. 
"Sem destino", A Noite, seção Risos e Lágrimas da Cidade, O Crime do Dia, Rio de Janeiro, terça-feira, 18 de novembro de 1952, p. 9.

"A rua", A Noite, seção Risos e Lágrimas da Cidade, O Crime do Dia, Rio de Janeiro, quarta-feira, 19 de novembro de 1952, p. 11.

"Veneno", A Noite, seção Risos e Lágrimas da Cidade, O Crime do Dia, Rio de Janeiro, quinta-feira, 20 de novembro de 1952, p. 11.

"Dorinha", A Noite, seção Risos e Lágrimas da Cidade, O Crime do Dia, Rio de Janeiro, sábado, 22 de novembro de 1952, p. 11.

"Noite", A Noite, seção Risos e Lágrimas da Cidade, O Crime do Dia, Rio de Janeiro, terça-feira, 25 de novembro de 1952, p. 9.

"Acidente", A Noite, seção Risos e Lágrimas da Cidade, O Crime do Dia, Rio de Janeiro, quarta-feira, 26 de novembro de 1952, p. 11.

"Uma proposta", A Noite, seção Risos e Lágrimas da Cidade, O Crime do Dia, Rio de Janeiro, quinta-feira, 27 de novembro de 1952, p. 11.

"Solidão", A Noite, seção Risos e Lágrimas da Cidade, O Crime do Dia, Rio de Janeiro, sexta-feira, 28 de novembro de 1952, p. 7.

"Dona Laurinda", A Noite, seção Risos e Lágrimas da Cidade, O Crime do Dia, Rio de Janeiro, sábado, 29 de novembro de 1952, p. 11.

\section{DEZEMBRO DE 1952}

"O noivo", A Noite, seção Risos e Lágrimas da Cidade, O Crime do Dia, Rio de Janeiro, quarta-feira, 3 de dezembro de 1952, p. 11.

"O herdeiro", A Noite, seção Risos e Lágrimas da Cidade, O Crime do Dia, Rio de Janeiro, quinta-feira, 4 de dezembro de 1952, p. 11.

"Dívida", A Noite, seção Risos e Lágrimas da Cidade, O Crime do Dia, Rio de Janeiro, sábado, 13 de dezembro de 1952, p. 9.

"Seca", A Noite, seção Risos e Lágrimas da Cidade, O Crime do Dia, Rio de Janeiro, segunda-feira, 15 de dezembro de 1952, p. 5. 
"O cavalo da noite", A Noite, seção Risos e Lágrimas da Cidade, O Crime do Dia, Rio de Janeiro, terça-feira, 16 de dezembro de 1952, p. 9.

"O rapto", A Noite, seção Risos e Lágrimas da Cidade, O Crime do Dia, Rio de Janeiro, quarta-feira, 17 de dezembro de 1952, p. 9.

“Amanhã", A Noite, seção Risos e Lágrimas da Cidade, O Crime do Dia, Rio de Janeiro, quinta-feira, 18 de dezembro de 1952, p. 9.

"A descoberta", A Noite, seção Risos e Lágrimas da Cidade, O Crime do Dia, Rio de Janeiro, sexta-feira, 19 de dezembro de 1952, p. 5.

"Além da morte", A Noite, seção Risos e Lágrimas da Cidade, O Crime do Dia, Rio de Janeiro, sábado, 20 de dezembro de 1952, p. 9.

"Sorte grande", A Noite, seção Risos e Lágrimas da Cidade, O Crime do Dia, Rio de Janeiro, quarta-feira, 24 de dezembro de 1952, p. 11.

"Fim de ano", A Noite, seção Risos e Lágrimas da Cidade, O Crime do Dia, Rio de Janeiro, sábado, 27 de dezembro de 1952, p. 9.

"O mascate", A Noite, seção Risos e Lágrimas da Cidade, O Crime do Dia, Rio de Janeiro, terça-feira, 30 de dezembro de 1952, p. 9.

"Amigos", A Noite, seção Risos e Lágrimas da Cidade, O Crime do Dia, Rio de Janeiro, quarta-feira, 31 de dezembro de 1952, p. 9.

\section{$\underline{1953}$}

\section{JANEIRO DE 1953}

"Notas de um diário", A Noite, seção Risos e Lágrimas da Cidade, O Crime do Dia, Rio de Janeiro, sábado, 3 de janeiro de 1953, p. 9.

"Irmãs", A Noite, seção Risos e Lágrimas da Cidade, O Crime do Dia, Rio de Janeiro, terça-feira, 6 de janeiro de 1953, p. 9.

"Gatinha", A Noite, seção Risos e Lágrimas da Cidade, O Crime do Dia, Rio de Janeiro, quarta-feira, 7 de janeiro de 1953, p. 9.

"Acidente", A Noite, seção Risos e Lágrimas da Cidade, O Crime do Dia, Rio de Janeiro, quinta-feira, 8 de janeiro de 1953, p. 9. 
“A tia”, A Noite, seção Risos e Lágrimas da Cidade, O Crime do Dia, Rio de Janeiro, sábado, 10 de janeiro de 1953, p. 9.

"Emilia", A Noite, seção Risos e Lágrimas da Cidade, O Crime do Dia, Rio de Janeiro, terça-feira, 13 de janeiro de 1953, p. 9.

“Zizinha”, A Noite, seção Risos e Lágrimas da Cidade, O Crime do Dia, Rio de Janeiro, quinta-feira, 15 de janeiro de 1953, p. 11.

"Abismo", A Noite, seção Risos e Lágrimas da Cidade, O Crime do Dia, Rio de Janeiro, sexta-feira, 16 de janeiro de 1953, p. 9.

"O vento", A Noite, seção Risos e Lágrimas da Cidade, O Crime do Dia, Rio de Janeiro, sábado, 17 de janeiro de 1953, p. 9.

"O baile", A Noite, seção Risos e Lágrimas da Cidade, O Crime do Dia, Rio de Janeiro, terça-feira, 20 de janeiro de 1953, p. 9.

"Maconha", A Noite, seção Risos e Lágrimas da Cidade, O Crime do Dia, Rio de Janeiro, quarta-feira, 21 de janeiro de 1953, p. 9.

"A estreia", A Noite, seção Risos e Lágrimas da Cidade, O Crime do Dia, Rio de Janeiro, quinta-feira, 22 de janeiro de 1953, p. 9.

“Gás”, A Noite, seção Risos e Lágrimas da Cidade, O Crime do Dia, Rio de Janeiro, sexta-feira, 23 de janeiro de 1953, p. 9.

"Junto ao córrego", A Noite, seção Risos e Lágrimas da Cidade, O Crime do Dia, Rio de Janeiro, sábado, 24 de janeiro de 1953, p. 9.

"O caramanchão", A Noite, seção Risos e Lágrimas da Cidade, O Crime do Dia, Rio de Janeiro, quarta-feira, 28 de janeiro de 1953, p. 11.

"Vício", A Noite, seção Risos e Lágrimas da Cidade, O Crime do Dia, Rio de Janeiro, quinta-feira, 29 de janeiro de 1953, p. 9

"Cantiga", A Noite, seção Risos e Lágrimas da Cidade, O Crime do Dia, Rio de Janeiro, sábado, 31 de janeiro de 1953, p. 9. 


\section{FEVEREIRO DE 1953}

"A afogada", A Noite, seção Risos e Lágrimas da Cidade, O Crime do Dia, Rio de Janeiro, terça-feira, 3 de fevereiro de 1953, p. 9.

"Vampiro", A Noite, seção Risos e Lágrimas da Cidade, O Crime do Dia, Rio de Janeiro, sexta-feira, 6 de fevereiro de 1953, p. 5.

"Pela janela", A Noite, seção Risos e Lágrimas da Cidade, O Crime do Dia, Rio de Janeiro, sábado, 7 de fevereiro de 1953, p. 9.

"Carnavalesco", A Noite, seção Risos e Lágrimas da Cidade, O Crime do Dia, Rio de Janeiro, terça-feira, 10 de fevereiro de 1953, p. 9.

"O chapéu", A Noite, seção Risos e Lágrimas da Cidade, O Crime do Dia, Rio de Janeiro, quarta-feira, 11 de fevereiro de 1953, p. 9.

"Estação", A Noite, seção Risos e Lágrimas da Cidade, O Crime do Dia, Rio de Janeiro, quinta-feira, 12 de fevereiro de 1953, p. 9.

"O sacristão", A Noite, seção Risos e Lágrimas da Cidade, O Crime do Dia, Rio de Janeiro, sexta-feira, 13 de fevereiro de 1953, p. 5.

"Teresinha", A Noite, seção Risos e Lágrimas da Cidade, O Crime do Dia, Rio de Janeiro, sexta-feira, 20 de fevereiro de 1953, p. 5.

“Amantes", A Noite, seção Risos e Lágrimas da Cidade, O Crime do Dia, Rio de Janeiro, sábado, 21 de fevereiro de 1953, p. 9.

“O cadáver", A Noite, seção Risos e Lágrimas da Cidade, O Crime do Dia, Rio de Janeiro, quarta-feira, 25 de fevereiro de 1953, p. 9.

“Junto ao portão", A Noite, seção Risos e Lágrimas da Cidade, O Crime do Dia, Rio de Janeiro, sexta-feira, 27 de fevereiro de 1953, p. 5.

\section{MARÇO DE 1953}

"O cavalo azul”, A Noite, seção Risos e Lágrimas da Cidade, O Crime do Dia, Rio de Janeiro, terça-feira, 3 de março de 1953, p. 9.

"A verdade", A Noite, seção Risos e Lágrimas da Cidade, O Crime do Dia, Rio de Janeiro, quinta-feira, 5 de março de 1953, p. 9. 
"O marido", A Noite, seção Risos e Lágrimas da Cidade, O Crime do Dia, Rio de Janeiro, sábado, 7 de março de 1953, p. 10.

"O beijo", A Noite, seção Risos e Lágrimas da Cidade, O Crime do Dia, Rio de Janeiro, quinta-feira, 12 de março de 1953, p. 9.

"A vítima", A Noite, seção Risos e Lágrimas da Cidade, O Crime do Dia, Rio de Janeiro, sexta-feira, 13 de março de 1953, p. 11.

"Arquimedes", A Noite, seção Risos e Lágrimas da Cidade, O Crime do Dia, Rio de Janeiro, sábado, 14 de março de 1953, p. 9.

"O valentão", A Noite, seção Risos e Lágrimas da Cidade, O Crime do Dia, Rio de Janeiro, quarta-feira, 18 de março de 1953, p. 9.

"A família", A Noite, seção Risos e Lágrimas da Cidade, O Crime do Dia, Rio de Janeiro, quinta-feira, 19 de março de 1953, p. 9.

"Um crime", A Noite, seção Risos e Lágrimas da Cidade, O Crime do Dia, Rio de Janeiro, sexta-feira, 20 de março de 1953, p. 5.

"O passageiro", A Noite, seção Risos e Lágrimas da Cidade, O Crime do Dia, Rio de Janeiro, sábado, 21 de março de 1953, p. 11.

"Boêmio", A Noite, seção Risos e Lágrimas da Cidade, O Crime do Dia, Rio de Janeiro, quinta-feira, 26 de março de 1953, p. 5.

"Canoa", A Noite, seção Risos e Lágrimas da Cidade, O Crime do Dia, Rio de Janeiro, sexta-feira, 27 de março de 1953, p. 9.

"O outro", A Noite, seção Risos e Lágrimas da Cidade, O Crime do Dia, Rio de Janeiro, sábado, 28 de março de 1953, p. 11.

\section{ABRIL DE 1953}

"Assombração", A Noite, seção Risos e Lágrimas da Cidade, O Crime do Dia, Rio de Janeiro, quarta-feira, $1^{\circ}$ de abril de 1953, p. 10.

"Orozimbo", A Noite, seção Risos e Lágrimas da Cidade, O Crime do Dia, Rio de Janeiro, quinta-feira, 2 de abril de 1953, p. 9. 
“Contraventores", A Noite, seção Risos e Lágrimas da Cidade, O Crime do Dia, Rio de Janeiro, terça-feira, 7 de abril de 1953, p. 9.

"Cascavel", A Noite, seção Risos e Lágrimas da Cidade, O Crime do Dia, Rio de Janeiro, quarta-feira, 15 de abril de 1953, p. 11.

"No banheiro", A Noite, seção Risos e Lágrimas da Cidade, O Crime do Dia, Rio de Janeiro, quinta-feira, 16 de abril de 1953, p. 9.

“Avante", A Noite, seção Risos e Lágrimas da Cidade, O Crime do Dia, Rio de Janeiro, sábado, 18 de abril de 1953, p. 9.

"A medalha”, A Noite, seção Risos e Lágrimas da Cidade, O Crime do Dia, Rio de Janeiro, quinta-feira, 23 de abril de 1953, p. 9.

\section{MAIO DE 1953}

"Caso real", A Noite, seção Risos e Lágrimas da Cidade, O Crime do Dia, Rio de Janeiro, quarta-feira, 6 de maio de 1953, p. 11.

"Mendigos", A Noite, seção Risos e Lágrimas da Cidade, O Crime do Dia, Rio de Janeiro, quinta-feira, 7 de maio de 1953, p. 9.

"A partida", A Noite, seção Risos e Lágrimas da Cidade, O Crime do Dia, Rio de Janeiro, sexta-feira, 8 de maio de 1953, p. 5.

"Feira", A Noite, seção Risos e Lágrimas da Cidade, O Crime do Dia, Rio de Janeiro, segunda-feira, 11 de maio de $1953,2^{a}$ seção, p. 5.

"O coronel”, A Noite, seção Risos e Lágrimas da Cidade, O Crime do Dia, Rio de Janeiro, terça-feira, 12 de maio de 1953, p. 9.

"Orfanato", A Noite, seção Risos e Lágrimas da Cidade, O Crime do Dia, Rio de Janeiro, quarta-feira, 13 de maio de 1953, p. 10.

"Neblina", A Noite, seção Risos e Lágrimas da Cidade, O Crime do Dia, Rio de Janeiro, quinta-feira, 21 de maio de 1953, p. 9.

"Consultório", A Noite, seção Risos e Lágrimas da Cidade, O Crime do Dia, Rio de Janeiro, sexta-feira, 22 de maio de 1953, p. 7. 
"Manicura", A Noite, seção Risos e Lágrimas da Cidade, O Crime do Dia, Rio de Janeiro, segunda-feira, 25 de maio de 1953, $2^{\text {a }}$ seção, p. 5.

"O ajuste", A Noite, seção Risos e Lágrimas da Cidade, O Crime do Dia, Rio de Janeiro, quinta-feira, 28 de maio de 1953, p. 9.

"Loteria", A Noite, seção Risos e Lágrimas da Cidade, O Crime do Dia, Rio de Janeiro, sexta-feira, 29 de maio de 1953, p. 7.

\section{JUNHO DE 1953}

"Calúnia", A Noite, seção Risos e Lágrimas da Cidade, O Crime do Dia, Rio de Janeiro, sexta-feira, 5 de junho de 1953, p. 5.

"Japonesa", A Noite, seção Risos e Lágrimas da Cidade, O Crime do Dia, Rio de Janeiro, sábado, 6 de junho de 1953, p. 10.

"Sara", A Noite, seção Risos e Lágrimas da Cidade, O Crime do Dia, Rio de Janeiro, quarta-feira, 10 de junho de 1953, p. 9.

"Vingança", A Noite, seção Risos e Lágrimas da Cidade, O Crime do Dia, Rio de Janeiro, sexta-feira, 12 de junho de 1953, p. 11.

"A infiel”, A Noite, seção Risos e Lágrimas da Cidade, O Crime do Dia, Rio de Janeiro, sábado, 13 de junho de 1953, p. 9.

"A vala", A Noite, seção Risos e Lágrimas da Cidade, O Crime do Dia, Rio de Janeiro, quarta-feira, 17 de junho de 1953, p. 9.

"Casanova”, A Noite, seção Risos e Lágrimas da Cidade, O Crime do Dia, Rio de Janeiro, sexta-feira, 19 de junho de 1953, p. 11.

"A tirania", A Noite, seção Risos e Lágrimas da Cidade, O Crime do Dia, Rio de Janeiro, sábado, 20 de junho de 1953, p. 5.

"Alaíde", A Noite, seção Risos e Lágrimas da Cidade, O Crime do Dia, Rio de Janeiro, sexta-feira, 26 de junho de 1953, p. 11.

"Galateia", A Noite, seção Risos e Lágrimas da Cidade, O Crime do Dia, Rio de Janeiro, sábado, 27 de junho de 1953, p. 9. 


\section{JULHO DE 1953}

"Pano verde", A Noite, seção Risos e Lágrimas da Cidade, O Crime do Dia, Rio de Janeiro, quarta-feira, $1^{\circ}$ de julho de 1953, p. 9.

"O papagaio", A Noite, seção Risos e Lágrimas da Cidade, O Crime do Dia, Rio de Janeiro, sexta-feira, 3 de julho de 1953, p. 11.

"A filha", A Noite, seção Risos e Lágrimas da Cidade, O Crime do Dia, Rio de Janeiro, quarta-feira, 8 de julho de 1953, p. 10.

"A visita", A Noite, seção Risos e Lágrimas da Cidade, O Crime do Dia, Rio de Janeiro, quinta-feira, 9 de julho de 1953, p. 9.

"Vidas", A Noite, seção Risos e Lágrimas da Cidade, O Crime do Dia, Rio de Janeiro, sexta-feira, 10 de julho de 1953, p. 11.

"O gato", A Noite, seção Risos e Lágrimas da Cidade, O Crime do Dia, Rio de Janeiro, quinta-feira, 16 de julho de 1953, p. 9.

“Anastácia", A Noite, seção Risos e Lágrimas da Cidade, O Crime do Dia, Rio de Janeiro, sexta-feira, 17 de julho de 1953, parte I, p. 9.

“Anastácia”, A Noite, seção Risos e Lágrimas da Cidade, O Crime do Dia, Rio de Janeiro, sábado, 18 de julho de 1953, parte II, p. 5.

"Alberto", A Noite, seção Risos e Lágrimas da Cidade, O Crime do Dia, Rio de Janeiro, sexta-feira, 24 de julho de 1953, p. 11.

\section{6}

\section{Correspondência}

ANDRADE, M. Correspondência pessoal. Arquivo de Lúcio Cardoso, AMLB, Fundação Casa de Rui Barbosa, LC 13, cp.

BANDEIRA, M. Correspondência para Lúcio Cardoso, em 17 de janeiro de 1939, AMLB, Fundação Casa de Rui Barbosa, LC 24 cp.

CARDOSO, L. Arquivo Vinicius de Moraes, manuscrita, 1935, VM cp116, AMLB, Fundação Casa de Rui Barbosa. 
MORAIS, V. de. Arquivo Lúcio Cardoso, LC 155, cp 30 de janeiro de 1935 a 15 de abril de 1936, AMLB, Fundação Casa de Rui Barbosa. 


\section{Anexos}

\section{1}

\section{Anexo Crimes}

\section{ANEXO CRIMES bloco de anotaçōes}

\section{CASO ESTRANGULAMENTO NA PRAÇA DA REPÚBLICA}

A Noile - Segunda-feira, 10 de outubro de 1949, p. 1 e cont. p. 3

\section{O Estrangulamento de aatigo fiscal do Imposto de Consame}

Completo mistério envolve ainda latrocinio do Ediffcio Aclamaçào - $O$ cadiver tinha as màos amarradas nas costas - A vitima vivia sozinha no apartamento 303 , onde recebia visitas - Era homem de recursos - Dado o alarme por um sargento do Exército que ia visitá-lo - A policia procura um trocador de ónibus - A autopsia OBS: Há uma foto.

Legenda: $\mathrm{O}$ corpo de Demóstenes, com as màos amarradas, no local en que foi encentrado, quando era examinado pelos peritos:

Esth novamente a policia is voltas com um tenebraso crime misterioso, ocorrido no edificio Aclamaç̣̂o, na Praça da Repóbłica, no apartamento 303. Mataram ałi um homem quase septuagenărio, A vitima foi manietada estrungulada. Depois disso, os seus matadores, ou matador, saquearam todo o apartamento, levando possivelmente todos 05 ( . . ) veres encontrados, pvis o morto era homem de (_.) aposentado do Imposto de Consumo. Avisada do crime, a policia do $10^{\circ}$ distrito, representada pelo deleseado Marinho Reis e pelo comissário Marcos, compareceu ao local, iniciando logo uma série de diligências, que, ao que parece, levarâo à descoberta do criminoso.

\section{Come foi dado o alarme}

No apartamento, n. 303 residia Demóstenes Oliveira da Veiga, de 67 anos, fiscal aposentado do Imposto do Consumo e homem de largos recursos, proprictairio de várias casas no estado de Santa Catarina. Dizem mesmo que ele era dono de nada menos de umass centenas de imōveis em Florianópolis. Demóstenes tinha uma viđa de isolamento. Pouco saia, permanecendo no apartamento na maior parte do tempo. Homem demasiadamente económico, era ele próprio quem cozinhava e lavava suas roupas. No apartamento reinava completa desordem. A falta de asseio ena absoluta. Louças servidas c. roupas usadas foram encontradas sobre móveis, causando desagradivel impressăo, $O$ apartamento ć composto de sala, quarta e cozinha, tudo muito acanuhado. Os móveis 
todos empoeirados davam a impressâo de não serem limpos há muito tempo. Era nesse ambiente que vivia um homem de grandes posses. As visitas que recebia eram sempre de homens que se demoravam geralmente de duas a trếs horas. Como o apartamento fosse de propriedade de Demóstenes e nunca se verificou ali qualquer ato que despertasse a atençào da vizinhança, os empregados da administraçâo do edificio não sc preocupavam com Demóstenes. Havia uma sala de jantar e uma rede e junto dela, um par de chinelos. Havia tambèm uma vastissima correspondēncia sobre um móvel. Foi o sargento do exército, Álvaro Ermelino Ribeiro, que ali fora cm visita a Demóstenes, velho amigo de seu pai, quem encontrou o corpo. O sargento, após apertar o portão da companhia, várias vezes, sem ser, entretanto, atendido, verificou que a porta estava aberta. Entrou, entâo, no apartamento e deu com o corpo de Demóstenes estendido em decúbito dorsal. Horrorizado desceu as escadas e foi dar ciễneia do que vira ao porteiro do edificio que tomou a iniciativa de avisar a policia do $10^{\circ}$ distrito. Minutos depois chegava ali o comissário Marcos e o delegado Marinho Reis, desde logo ficou evidenciado que se tratava de um bárbaro latrocinio. Foram então chamados a pericia e a Policia Técnica. Compareceram imediatamente os detetives Hélio Machado e Edson. O corpo como dissemos acima foi encontrado em decúbito dorsal. Estava apenas vestido de camisa, de meias e cuecas. As pernas cstavam amarradas com uma gravata preta $\mathrm{e}$ as màos fortemente amarradas às costas. No pescọ̧o uma camisa velha com a qual fora estrangulado a vitima. As condições em que foi encontrado o cadáver eram verdadeiramente estranhas, nåo permitindo sequer hipóteses sobre como se teria desenvolvido o crime.

A procura de um trocador de ônibus - os frequientadores de apartamento Entrando a interrogar os empregados e morados do edificio Aclamação, soube o delegado Marinho Reis, que o apartamento do velho Demóstenes era freqüentado por varios rapazes e um trocador de ônibus, de nome Jorge de tal, de cor morena, baixo e de compleiçào robusta. Este ia ali diariamente, entrando, geralmente, às $12 \mathrm{~h}$ e saindo quase sempre às 14 horas. Jorge está sendo procurado pela policia que até agora não conseguiu prendẽ-lo. Souberam ainda as autoridade, por intermédio do sargento Álvaro Ribeiro, que era hábito do velho ter sempre grandes quantias em casa, chegando mesmo ele a ver certa vez, em cima de um móvel, um maço de notas de 500 e 1000 cruzeiros. Informou ainda o sargento que várias vezes ali estivera e o velho o atendia pelo postigo, dizendo que voltasse mais tarde, pois estava com visitas. Ainda na semana passada 
aconteceu isso, tendo o militar podido ver que no interior da casa havia um homem com o uniforme idêntico ao dos trocadores de ònibus.

\section{Removido corpo para o neerotério do IMIL}

Após os trabalhos de pericia, foi o corpo removido para o necrotério do IML, a fim de ser autopsiado pelo médico legista (...)

\section{Velho Demóstenes - tocou a campainha, mas não foì atenđida}

A vizinha do velho assassinado é a senhora Eunice Lessa que, falando $A$ noile, disse que sempre se utilizava do telefone da vitima. Ainda sábado, por volta das $20 \mathrm{~h}$, precisando falar ao telefone, foí até o spartamento de Demóstenes, apertando a campainha várías vezes. Pode pereeber que a luz estava acesa, como nào fosse atendida, voltou para seu apartamento, sem de nada suspeitar.

\section{Fala A noite o sargento Ribeiro - os motivos de sua visita}

Após depor no cartório da delegacia do $10^{\circ}$ distrito, o sargento Álvaro Ribeiro falou á reportagem de A Noite, Contou ele que esta servindo no $18^{\circ} \mathrm{r} .1$, em Porto Alegre, para onde fora transferido há tempos.

Viera ao Rio para ver se conseguia sua volta para aqui. Como tivesse dificuldade de conseguir passagem de volta, pois os navios estão superlotados de passageiros, procurou Demóstenes, velho amigo de seu pai, a fim de que esse intereedesse para que esse conseguisse as passagens, $O$ velho apelou para as suas amizades $e$ obteve as passagens para hoje. A visita que ia fazer ao morto era justamente para agradecer a interferência dele, quando deparou com o horrivel quadro.

Quanto à conduta do velho, Demóstenes, disse o sargento, ignorar por completo qualquer detalhe da saa vida particular.

\section{Os mataderes eram conhecidos do morto}

A policia chegou à conclusìo de que os matadores, ou o matador, conheciam bem Demóstenes, este teria aberto a porta para que eles entrassem pois não existe na mesma, nem em qualquer outra dependência do apartamento qualquer vestigio de violéncia. Encontraram ainda as autoridades policiais na vastissima correspondència apreendida, numerosas fotos, algumas delas com dedicatória. São fotos de rapazes de pouca idade. 
Na correspondência que fơ lìda com atenção nada se encontrou que pudesse eselarecer ou orientar as autoridades.

\section{Muito visitado o corpo - o resultado da autopsia}

Várias pessoas e todas elas de destaque, inclusive um coronel do exército, estiveram no necrotecrio do IML procurando visitar o corpo $(\ldots)$ pessoas eram conhecidas de Demóstenes lamentaram o ocorrido, exaltando as qualidades do morto. $\mathrm{O}$ dr. Nuno Lisbos, médico legista que autopsiou o corpo, atestou como causa mortis "estrangulamento".

\section{Iniciade o trabalhe ne cartório}

Por determinação do delegado do $10^{\circ}$ distrito foi instaurado inquérito para apurar o crime ocorrido no edificio Aclamaçào na Praça da República, possivelmente na madrugada de sábado. $\mathrm{O}$ comissàrio ali de dia, na noite de ontem, depois de fazer ouvir cm cartório o sargento que encontrou o cadáver do fiscal do Imposto de Consumo, iniciando assim os trabalhos de cartòrio, seguiu para o subúrbio leopoldinense da Penha, em companhia de auxiliares, para deter um jovem que seria o trocador de ónibus, suspeito de estar envolvido na morte de Demóstenes de Oliveira.

Até a hora em que encerrávamos o trabalho da presente ediçào, aquela autoridade nào regressara ainda à sede de sua delegacia.

\section{Será sepultado hoje}

O corpo de Demóstenes Oliveira da Veiga, como jă mencionamos, foi autopsiado no IML e será sepultado hoje, possivelmente pela manhà.

Segundo a reportagem de A Noite póde apurar, Demóstenes, que tinha comportamento estranho, vivendo sempre sỏ, era freqüentemente visitado no seu apartamento do edificio Aclamaçîo por militares das vărias corporaçôes, na companhia dos quais ena visto, por vezes, a passear pela Praça da República.

Apuramos ainda que o morto serviu nas imediaçâes de 1920, no território do Acre. como inspetor aduaneiro, quando era ali o seu chefe da mesa de rendas, o st. Alberto Pais, viajando pelas mesas de recolhimento próximo, inelusive de fronteira de Bolivia, de Peru e do Brasil, e dai esse nome. 
A vitima residiu em uma pensīo da rua do Riachuelo, onde se ergue hoje a Garagem Monumental, sendo que seu procedimento era o mesmo que se assinalava nos últimos dias de sua vida. Andava sempre em companhia de militares.

\section{Diligências do gabinete de pesquisas}

O fato parece caracterizar-se mesmo como um latrocinio. Demóstenes teria, ele próprio, dado entrada a seus assassinos ou assassino, sucumbindo a uma cilada mortal no apartamento n. 303, do edificio Aclamaçâo.

Após as primeiras diligễncias feitas na ocasiăo em que o corpo foi descoberto, as autoridades do gabinete de pesquisa da policia estiveram na tarde de ontem desde o meio dia, durante longo tempo no apartamento do morto, fazendo novos exames, nada sabendo sobre os resultados.

Embora se soubesse que a policia estava muito ativa nas suas sindicâncias para esclarecer a morte de Demóstenes de Oliveira, nào se conhecia o seu teor, nem se alguma prisalo đe suspeito fora feita.

OBS: Foto de Demóstenes.

Legenda: Demóstenes Oliveira da Veiga, antigo fiscal do Imposto de Consumo, que foi estrangulado.

O mistério do Edificio da Aclamação

A Noite-Quinta-feira, 13 de outubro de 1949. p. I. e cont. p. 6.

\section{A Noite descobre os autores do latrocinio}

A narrativa sensacional de um estudante que diz haver surpreendido os criminosos no apartamento de Demóstenes - Localizado pela nossa reportagem, Lydstone Sampaio Cavalcanti indica o "Paulista" e Flávio como os estranguladores do velho fiscal do Imposto do Consumo 


\section{As atividades dos apontados homicidas durante as horas que antecederam ao \\ crime - Encontro no campo de Santana, momentos antes, com uma manicure - A \\ fuga - "Paulista" saiu do apartamento, levando um pequeno embrulho, deixando o velho funcionário prostrado no chão}

OBS: Foto com o reclame

A Noite-Sexta-feira, 14 de outubro de 1949. p. 1.

OBS: Foto das impressōes digitais.

Foto com o reclame $<$ FINAL $>$.

CASO ESTRANGULAMENTO EM NITERÓI

Microfilme: PR SPR $155-v$. XXVIII Ano: 1950

A Noite - Sexta-feira, 19 de maio de 1950, p. 13.

\section{Estrangulado}

O local apresenta vestigios de luta - Bárbaro crime em Niterói

Na rua Mário Viana, 825, em Niterói, no bairro de Santa Rosa, onde era estabelecido com botequim, o sr. Lìcio Plácido de Loureiro Marques, portugués, solteiro, com 41 anos, foi encontrado estrangulado, $O$ corpo estava sobre o leito, nìo apresentando o estabelecimento qualquer vestigio de arrombamento. Apresenta também o local sinais de luta. Desconhece-se, porém, se houve roubo. O delegado Nicolau Amorim Vaz, do $2^{\circ}$ distrito de Santa Rosa, requisitou os serviços da Polícia Técnica, que trabalha para o esclarecimento do bárbaro crime, $\mathrm{O}$ morto era imào do conhecido pugilista brasileiro Kid Marques, ex-campeão da categoria dos penas. Falando à reportagem o antigo boxeador disse nầ saber a que atribuir o crime, de vez ser o irmâo benquisto na localidade, desconhecendo também se possuia inimigos. A Noite - Sábado, 20 de maio de 1950 , p. 2 e cont. p. 8. 
O crime horrivel do "Chave de ouro"

Amarrado, amordaçado e estrangulado - impressōes digitais colhidas no local e prisỗes - nâo houve roubo

Continua envolto em mistério o bảrbaro crime verificado no cafe "Chave de ouro", em Niterói, na rua Mário Viana , 825, no bairro de Santa Rosa. Lúcio Plácido de Lourciro Marques, dono do estabelecimento conforme $A$ Noife divulgou, homem de certa ilustraçào, sendo o mesmo correspondente do Jornal Noticias da Beira, de seu pais natal, foi encontrado no próprio leito amordaçado e estrangulado. Estava inteiramente despido. Em decúbito ventral, com lençol amarrado ao rosto, á guisa de mordaça e os braços e pernas também presos.

Foi o comerciário Oscar Teixeira, mais conhecido nas rodas da boemia por Casinho, que comunicou o caso às autoridades do $2^{\circ}$ distrito policial de Santa Rosa, Estranhou ele nào haver o negociante aberto o estabelecimento, como sempre o faxia às 5h. Embora tudo fosse estranho, cabe assinalar, só às $10 \mathrm{~h}$, ć que a policia foi notificada. Entrando em sindicâncias, o delegado Nicolau Amorim, desde logo, deteve Casinho. É que este há tempos responden pelo assalto a um bazar naquele bairro.

\section{Impressões digitais}

Requisitados os serviços periciais, esteve no botequim o perito Hermano Coelho Gomes, do Instituto de Policia Técnica. Muito embora o local estivesse revolvido por estranhos, o perito Coelho Gomes a que apurou $A$ moìte conseguiu levantar preciosos elementos capazes, possivelmente, de fornecer uma pista para melhor orientação das diligências.

Num despertador e em dois corpos foram levantadas impressôes digitais. No primeiro, foram colhidas fichas datiloscópicas de Gilson Monsores da Silva, solteiro, de 22 anos, residente na Av, Francisco de Sá, 921, em Belfort Roxo. Gilson fora empregado da vitima quando esta possuia uma quitada na rua Senador Alencar, $\mathrm{cm}$ Såo Cristóvào. Era mesmo protegido de Marques, com quem costumava pernoitar no pequeno quarto, nos fundos do estabelecimento.

Está detido, nutrindo a policia sérias suspeitas quanto a esse individuo 
Marques, depois de fechado o estabelecimento, reunia nos fundos, como estă noticiado, individuos estranhos, que viviam a explorá-lo.

\section{Mais um individuo}

Em face do desenrolar das sindicaincias Marques teria sido amordaçado c estrangulado por mais de uma pessoa. De hábitos estranhos, a vitima teria dado acesso ao estabelecimento pessoa de sua intimidade, Esta evidentemente com propósitos criminosos, jả havia tudo plancjado com seus cúmplices. Uma vez no interior da casa, logo depois deu entrada aos demais. Outro pormenor, que nào escapou à pericia, foi que o cafế nào fora assaltado. O quarto nâo apresentava maiores vestigios de luta embora a roups do leito tenha sido revolvida. Na caixa registradora fora encontrada pequena importância en niquel. $\mathrm{O}$ cofre, que à tarde foi aberto pelo senhor Loureiro Marques, também nâo apresentava vestigio de violéncia. No seu interior, arrecadou a importância de $35.000,00$ cruzeiros.

\section{Mais suspeitos incomunicáveis}

As diligências policiais não pararam ai. Durante a noite o delegado Amorim, agora com a colaboração do kr. José Alonso Otero, da delegacia de costumes, jogos e diversões, antigo comissário de policia, deteve vários suspeitos. Estes, ao que se sabe, eram frequèentadores do "Chave de Ouro", de onde so se retiravam altas horas da madrugada. Sào cles: Orlando Ferreira, solteiro, morador na estrada Cactano Monterio, s.n., Manuel Monteiro da Silveira, morador na rua Capitão Viveiros, 250 e Jordelino da Fonseca, sem profissào e moradia.

Esta madrugada, o investigador Valdemar, do $2^{*}$ distrito, vinha desenvolvendo atividades para capturar un ladrão conhecido por Taboinha. A prisẫo era csperada a qualquer instante.

O enterro de Marques será efetuado hoje, às $10 \mathrm{~h}$, a expensas de seu irmåo Antonio Loureiro Marques, ex guarda-municipal e antigo pugilista.

OBS: Foto do morto

Legenda: O corpo na cama $\mathrm{cm}$ que foi encontrado. 
QUEM Ė O BANDIDO "T"?

A Noite-Quinta-feira, 25 de maio de 1950, p. 1 e cont. p. 12.

\section{Telmo de Araújo, um dos fugitives}

[...] Telmo de Araújo, 18 anos de idade, que tendo errado, cumpre castigo.

Telmo, quando julgou que estava só, suspendeu o tampào da galeria de àguas e saltou para o interior. Segundos depois, dois companheiros, aproveitando-se da oportunidade estavam junto a ele. Eram José Moura e Jvo de Barros Jacob, ambos condenados a 10 anos de prisảo, constantes dos artigos 157 e 155, do Código Penal (roubo e assalto). [...]

\section{QUEM É O BANDIDO"T"?}

A Noite -Quinta-feira, 25 de maio de 1950. p. 1 e cont, p. 12.

\section{Telmo de Araújo, um dos fugitives}

[...] Telmo de Araújo, 18 anos de idade, que tendo crrado, cumpre castigo. Telmo, quando julgou que estava só, suspendeu o tampão da galeria de àguas e saltou para o interior. Segundos depois, dois companheiros, aproveitando-se da oportunidade estavam junto a ele. Enum José Moura e lvo de Barros Jacob, ambos condenados a 10 anos de prisảo, constantes dos artigos 157 e 155, do Código Penal (roubo e assalto). [...]

\section{QUEM Ė O BANDIDO "CARNE-SECA"?}

A Noîte - Sábado, 13 de maio de 1950. p. 1 e cont. p. 9

\section{Fugiu de nove!}

\section{"Carne-Seca" escapou da penitenciária, em companhia do ladrão, Angorá.}

João da Costa Resende, mais conhecido pelo vulgo de Came-Seca, apesar de muito moço ainda, é um perigoso delinqūente, que muito tem dado o que fazer à Justiça e à policia. Respondeu a numerosos processos, por assalto à mào armada, furtos, tentativa de homicidios, etc. Agia de preferência entre os bicheiros em companhia dos nĩo menos perigosos (...) Russo. 
Levava a efeito de assaltos contra bicheiros, usando violentos processos. Andava sempre fortemente armado $\mathrm{e}$ nào trepidava $\mathrm{em}$ fazer uso de suas armas, quando encontrava resistência a seus propósitos. 
7.2

Planilha Contos Gerais

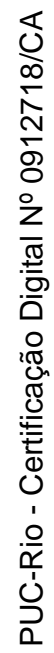

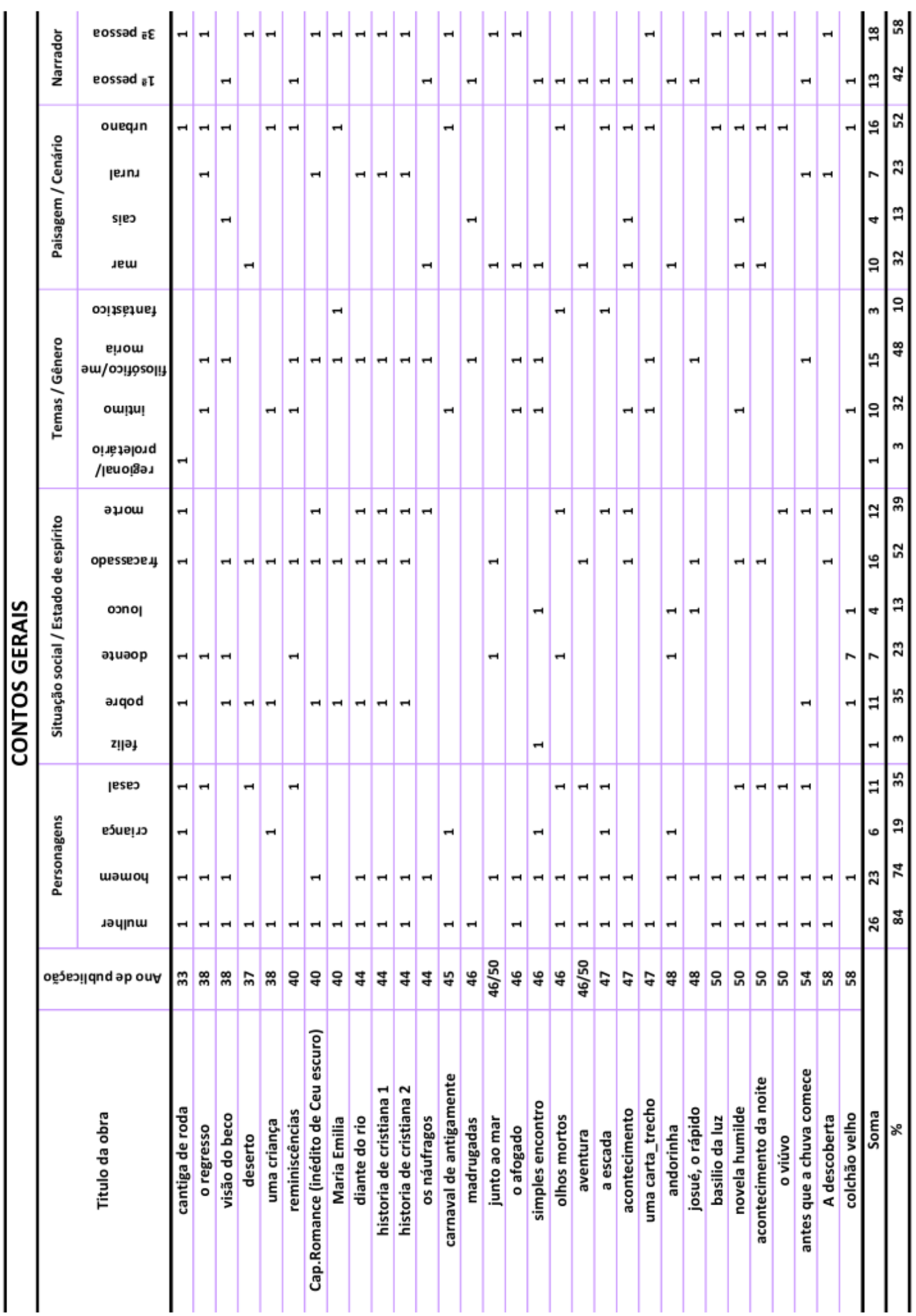




\section{3}

\section{Planilha Contos crime}

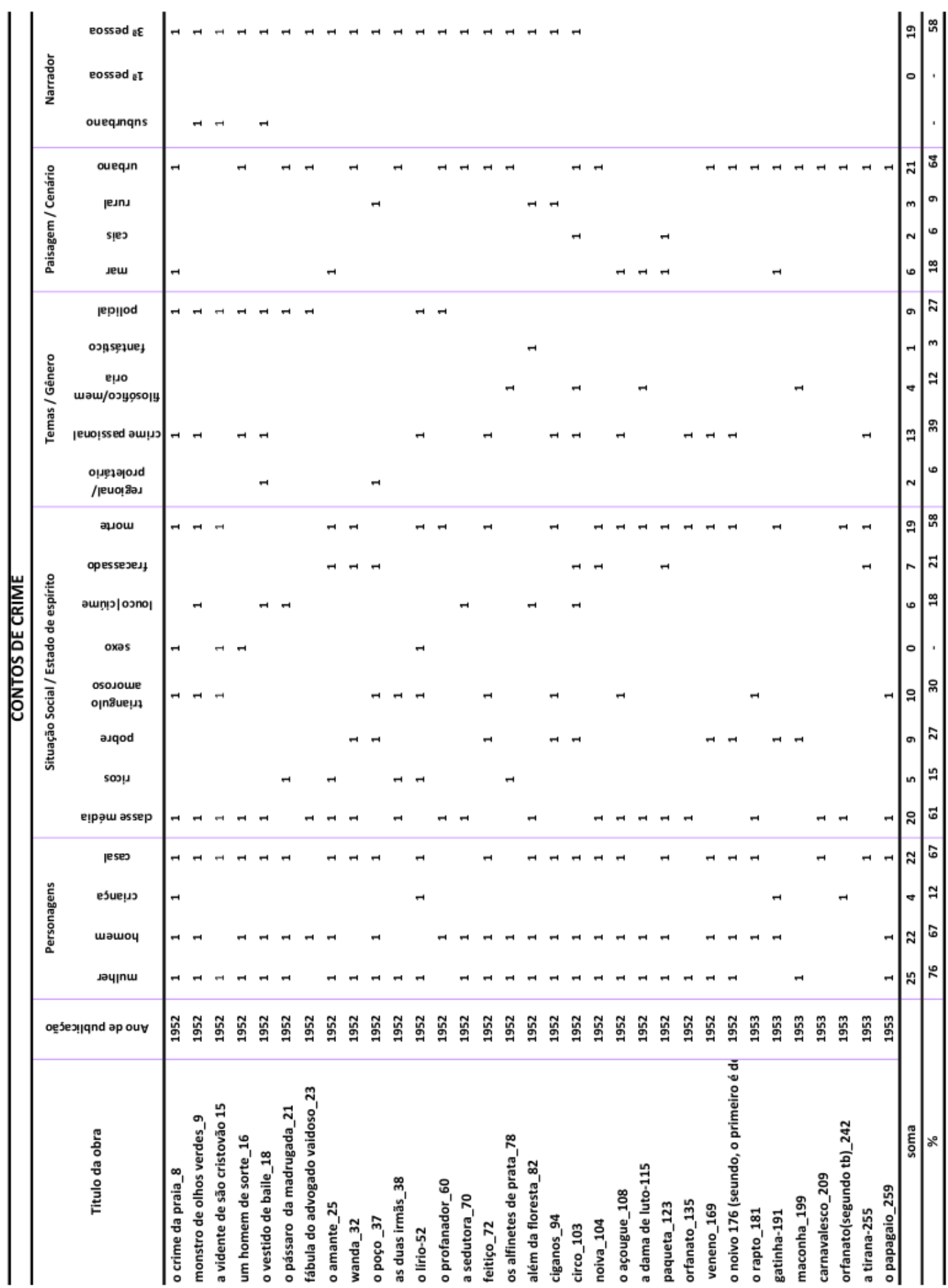




\section{4}

Originais Contos gerais

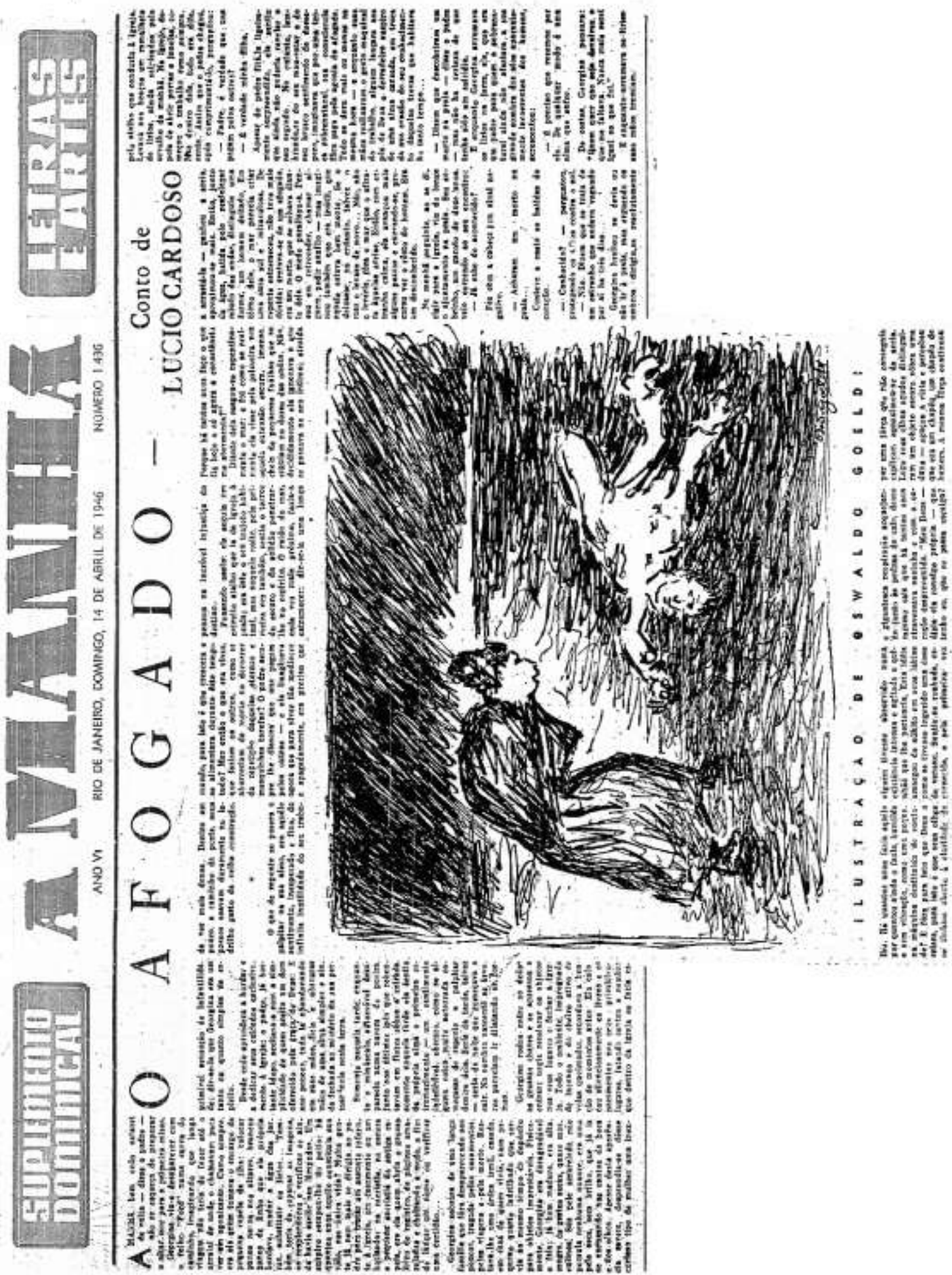




\section{A PAPOULA AZUL}

\section{Conto de LUCIO CARDOSO}

E tor um damingo pols maE mhà- o mar brilhava. ma maneira uniforme e llss, of contríria, grandes xense llumintdas vijiavan na superficio on dulada paso vento, contrastands cam a sombre qua os rochedoa do ilhs jeojetavam nígus. Ngas arrancades das pedras, pelo ütímo temporal, rolavam nas marón - en gainctes, há tanto tempo desaparecidas, surgiam sos bundose enchendo o ar de eritos dpldos e cortantes.

O peque-nique fóra combinado para dopols da misss, a junto palmeira designada para o encontra, duas das minhas compameiras fa se zenavam. De lonse.' vi 'on wus claros vestidos comands pelas podrac, saltando. na estoriteante sicgria quo mas gem.

- Lat La! - gritavam an. sim ave ma viram, Que troum E para o noses almage?

E sem esperar resposta, pusemim-so eariar en tams do $m_{4}$ selando o batendo paimsa. - On Lla, como á lindo sew vestidol como voct risa Cole vermalhs!

Coloquel no chão o pecuen casto que cu trazl. A pecuen Sora, mals caldow 60 que a ira, repertiu a pergunta:

iniso voct para moso, Lea?

- Huja enorangos - disso eu, suspendends o guardanapo - mo da sara.

- Oh, ou adoro morangos! gritou Sara, recamegando a sol-

Colocado o cesto funto as ou. tras provis des, ben abrigados sob a puimoira, lombs ver as rarids. das que ia tintam achido na prola: uma catrela do mar, seca - arrakedar algumas conciras quebradas E duas ou treis substrancis befitaosas, estrunhas, Trementes, de cor szulada, in ceria, que ainda pacecia oculat

- Culdado, Sara, isto quelma! - Vi - fez ela, sosndanands - maleria, que rolos inerte gol, Clen instande ainci, quecols unvel e arulaca - deposs uns end mak larte levou-a, in indevassivial munds exturo o II. quido.

- Adeus, Entiou a pequen Sara, volite outra vez ao fundo do mart
Continuarnos as nassas pesquicas e. como a espurra nos mo Thessa, tiramos os sapatos. Ma. rwithadas deixavamos que nos. sas pegadas se imprimissam no areia mole. O vol mas alta. a vasta extensio do mar. - Nio nos afasternes multo propuz eu - talver os cutros cheguem a nia ros encontrem. Do fato, autres compantheiros chegavam: Eduardo e a irmà, Ross e Marcelina. Ao todo camos sete - tinham tombinado aquele pique-niciesa para comemoramos da lenzo periodo de estudos como twamos soltregsos por lifberdade. ar livere, o vanto e as pralas l Como ithe nos perecoy um recant abencoodol bu ent30, a cecant. longa doença de meu poli retiver tantos meses d sus caboceira, ols va para aquilo tudo com um verdadeino sentimento de em lyiaguez. Uma energia nova dospenta realmanto no mea ser - isenta de cuidadas, turḱt, felit, eu corria de um lads pora culta sentindo a minhe alma se difatar como so fentro dils ounatrasse todo 0 arul do ocesno. Corriamos - e hudo ros senvla de pretexto sarb corrert uma onda miticr. ous nos as ostavs ums borboigta amarela yints do mato atcm e desserreds ma pras, um aviaso sertando alto c nitido a imensa ptacidez do céu...

Sim, lembn-me que Eduarde, de josthos solbrs a crvo, comia 8olsens morangos fur tades. Sara e Roso tinhem desaparcsido as lango da prois. Maecoflina, os cibelos bativos pelo vēnto, tentava escalar um rochedo para as suas förças. Foi nesse instante, exatamente, que vilo homem. Estava um pouso distante a nis pordis nenhum dos nossos movimantos. Era masro, alto e meros do as sua estranho atitude do dovervesoo, o que nele me chamou a stenclio desdo o inicio foi o chocanto contraste que offerecis com a par. sagem: nảo havio nuda om sua a slegria que nos cercava, ao contrírlo, vestis-es severamente do preto - asconds mals ou menos - rosto a sombra de um thaph também preto. Nlo sel poe quo, meu coraça so conitanges, nasse sentimuento havia algo do terror e da emopio com que haviamas contemolado minutos antes a substancia gelatinosa do mar. "Talves soia um doenta, um disses dontes tis comurs on procurzm o clima hospitaleiro da tha" - pensal comigo mesmo. O certo é qub, ssbendo-me observada, mints alegria nito foi mais tồ expontinas. Corris, corris zinde fuzindo das ondas, revols. teava atos pela prais - mas a figurs do estrants me obsedva. Lí estava Ale, imbrel, na mesno lugar. Mea Dauk, lamais abartdanaria aquelo posiçáo?

Pouco a pouco santi aue te. exercia certa atraçio sobre mim quase Dem querer, e stam saber porcase a fatis, fol me straximsendo sos soutes. Vi entio que seu rosts era tristh o severo.

- Bam dis, diste-me ale, sem dúvida esforçando-so para ser acothedor

- Bom dia, rtspondi eu, chels de susto, de receio e de curioge dade.

- Como se chema vocis per. Buntou=me.

- Gonito noma! E vieram fa zer um piave-nlque acui? - Sin viemos aproveitar menh

Ao mesmo temoo que es falava, pensava comigo mesmo: "A im doents, so poco sor um deante. Nunca vi ninguem tiso pslid

assim. Eve fazem vechs, cor- Oh, apanhamos conchas... strelas do mar... colisas por ai. Ele fitout-me severamente, com se tato nio tasse ocupstajo para uma menina da minha idado. - Is tom quinze enos? tornou a perguntar.

- Vou faztotos doasi a trest dias..

- Aht - a nlo disse mars

Por un instante oltow em tŏrno, coma se procurasse mexn comos. nheires com - vish. E de repente, cam voz surda e ligeiramente tremala ndagour

- Nào genta de flones? pondi.
Entas ble fet um sinat o mos. trou-mo o rochedo mals peobximo:

- All em cima há ums, maavilose....

- Ums que? - fit eu sem - Uns flor, uma papouls.

Nos acreditei e ri

- Papoulas nto dio sobbre as

Ele ranpourse e seu rosto se tonou miss stris ainds

- Esta 6 uma papoula espe.

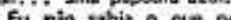

Eu nào sabia o gue pensar s ficuel ahando-a. Vi se actender paciència:

- Nào quer về-lot

- Quero... mas onde estia? - Por tris dagueles cactus. . haul nīo se vê.

satro es rochedos mais pnswimos cresciam giantescos cactus aca o vento do mar açoitaus Näo col se ey acreditava na aypoula axul, mas de qualever mansira misterio daguele homam me atrala. Acompanheli-e. Por tras da mim ouvia as risadas distan: tomem caminhava ne minhs fren.

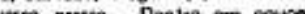
che prota. Dentro em posco chesavarios ao alto - e durame To

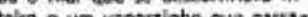

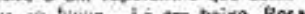

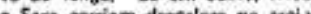
- Sara comiom destrican na sala enisuma

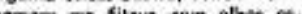
trankos. - Onde esta a mopoula? perguntel.

- Mi - mastrou-ras cto.

Olhei e não vi mids, só on cactus.

- Onde?

Ele se aproximsu. corro para - As ben ali

Othei de novo - e desta vex, senti de repente uma der aguda. horrivel, atrovessar-me o braço. Dei um grito, sem camaraender o ous forse. e erguendo-a, of que ougram tinha enterrado nille um comprito e notere esainho de eactus.

- O senhorl - cuelamei com

Eie me fitou com olbos de wue ama is mo esantermi, 13a duros. tao crués se mostravam Aa mes. The

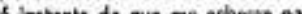
presenca de um louto

- Rona! Sera! - cormecei a gitar, con um fio de sangue me eseorner pela brazo.

De repente o hamem se afas. tort e deszeu pelas pedras, corren. do. O choséu caiu mesta coerida. Ele o apsnhou e cantinuou a cor. dit-10 de vists. 
DOMINGO, Q-2.1947

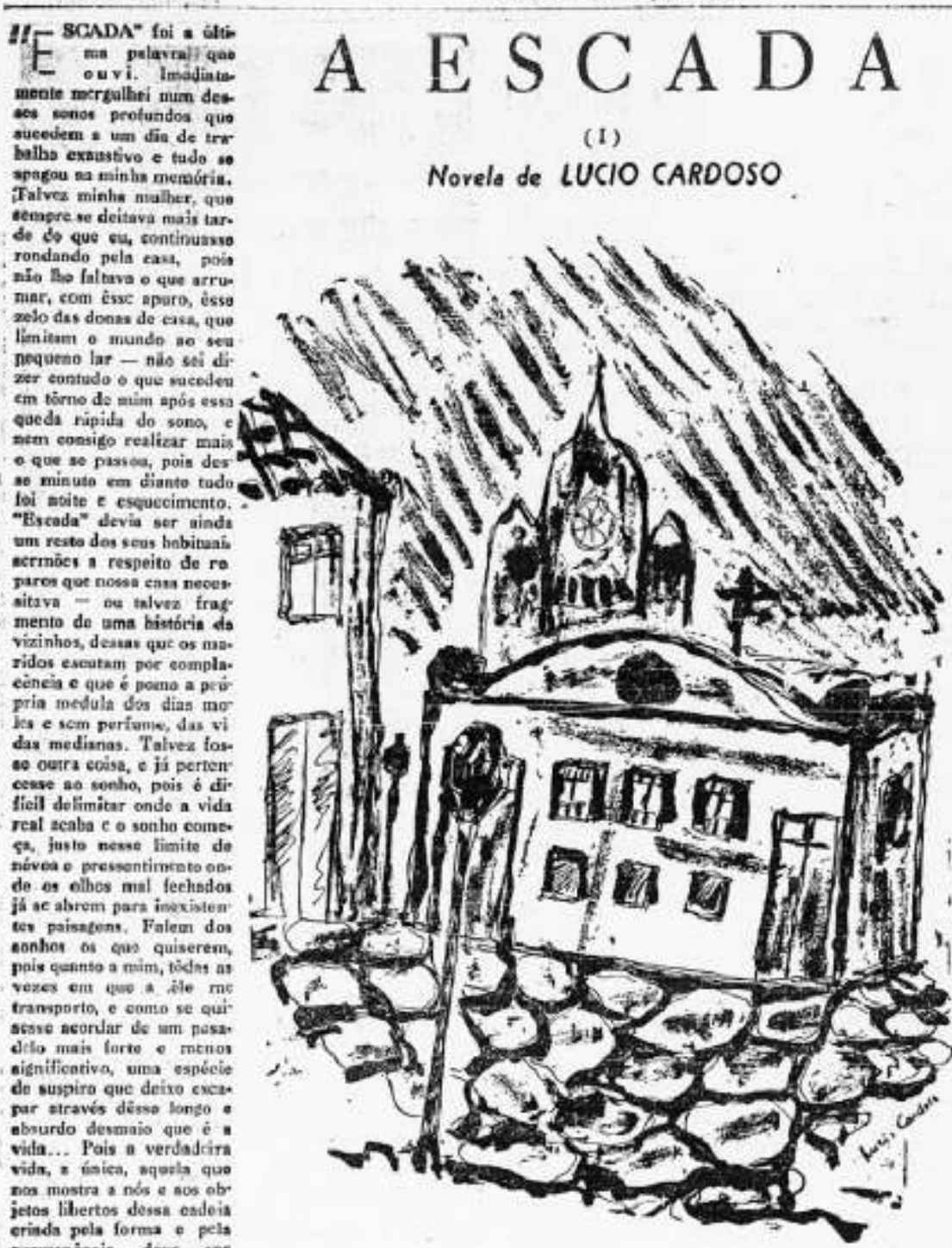

dever mats lonfe, do lado que ainds nāo atiagimos \& at6 ende somtnte o suno not
leva. Sim, repite que năo leva. Sim, repito que năo eiczda, man o certo 6 erie logo depois, em pleno mono, ouvi nitidumente alguén repetir, oom vox insistente e oode II trassparevin uma esta mesma palnvra: "ese: dn, estada". Nlesm soisu en mim estremeceu é meus ouvidos como gue se dilataram. Ouvi entāo, com extraordinária nitidio, uma voz feminins, solest : grave, repetir: "pela escasei se reslmente disse ou so apenas tive inteneón de dixer: "que esesda P" $\mathrm{B}$ a mesms vor, como se tives. ac escutido a minhta, coclar reces: "a do fundo an do rees: "a do fundia, " do tio, comb se eontinenss um dáloto isiciade mais antes, mas de que so afora tivese conseicheis dn wat continuscio, torneis "mas nais sei ende é a casa". B an mocu ouvido: "é na rua X..." Repeti oumise nes.

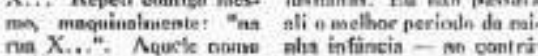
e novo a tons. Som dir de sombras e perfunes da* visäo preservada acio feidn.

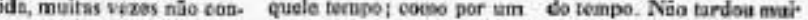

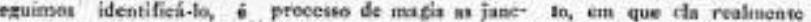

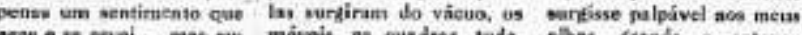

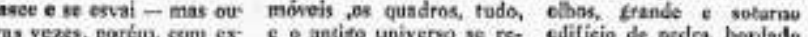

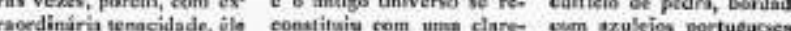

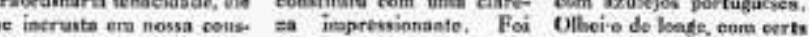

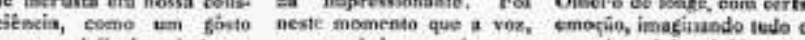

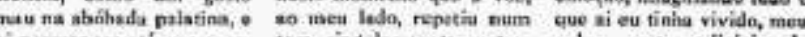

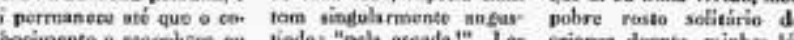

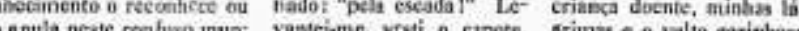

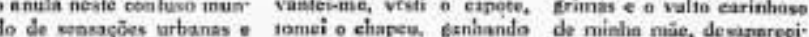
em interésec. A fírça de a raa. Comiga mesmo do há tuatos anos. Um

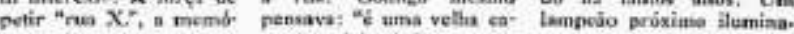

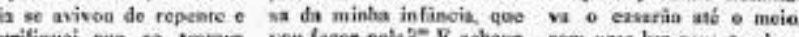

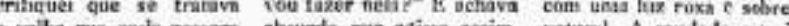

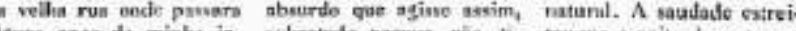

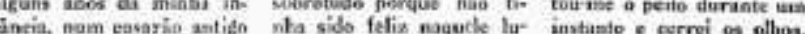

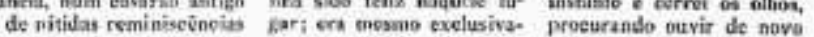

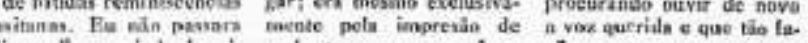

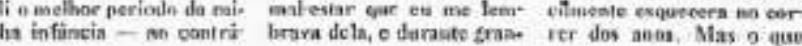
asi noranente toi s vom auteritirin o allita: "Pein e expurrei : porta, uma porn alts, estreita, eneima. da por um arabesco de les ro. Nảo me ndmirei de nue a eieontrasse aberta. Meu cerapio pús-se a bater cem mais fộress, ante $r$ intreme ceada sionosa, creurs. coberts de poeirs, que por ume estrantu fidelidede teropo, aind conserveva meame cheire erreorio pee eu cophecers an into tin. Eers ynse na intara madein vellos o moto do um odor aecrito foros dave to antion loces, que péei de personalida pieno do porvoralidade som lane of misticriosa, sume. entides an andias tentiges ou ambientes abanNio ha muito tempo. Nio existia ecnlama luz exceto no alto uma ciaridade maito tenoe, tîo to nue quants o prinatiro rom sado da manhia entrevisto através das vidracas descidas. Dirse-sal uma laz cor laseds muito lonte, no our tra exirenie da na, e que, reaimente, atraves dos vis dron enviasse iquela esea. da o seu pálido reflexu. Risquei um fósforo e ea mecei a subir devagarinho, Ao chefar no alte estugusi, proeturando orientar me. Alux vinlas de uin quarto ao fundo, no extremo do um corredor que partis do ha. far erm que ev eutava na. ivole momeasa, isto $e_{\text {, uma }}$ unplas sala, de teto elevado t mobiliada eont matveis so" neros $\mathrm{C}$ antiros. As pare des eram forridas de panel manehado, exan desention imitanda erardes ovais eta moidura marres. Una las. tre pendia do slto $x$ seus pingeates de eristal brillat. vam conforme os movimen. pos ques su hazia con a ca beça. Detallbe por detallie, fui reosehotende a exsa ent que habitars autrors, deste as janclas larges, ceultas por peiadas corti. tio me era estranbo. Suat rie, labitara nele numa de parte da minha vida do a ouro, ató a eavidado

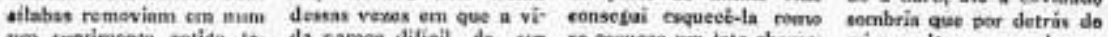
um sentimento antiga, is. da parece dilisil de sir se csqueee un tato aborre: mim ocultava a esonda poe

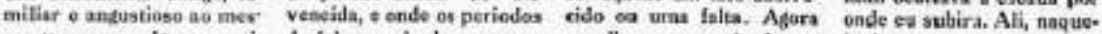
mo tempo, um dosses senti de fohre o do doenga para a vellia cass surgia de so lo ludar emi que cu akora

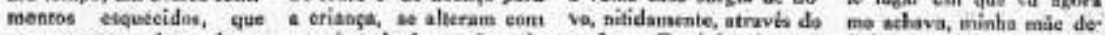
permanecent sob as einzas, as crists de depressán e de sonbo. Caminlanda, eu finhara de estranha molés.

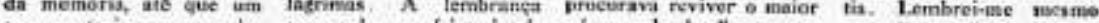

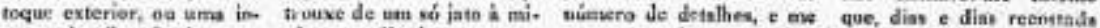

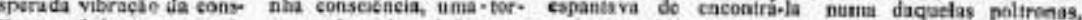

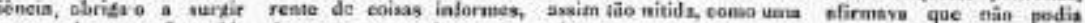
Jormir, aue cicus podia mores, que escutava rur dedo trimalo as anden inanchas, provsveimenso criunds de mofo ou de unidade oue se alartavam nas paredes.

(Contiena).

\section{a ULTIMA DE SARTEE}

Jiar-lival Sartis, a ficun atual, E eriador in exislentis: expseta $\mathrm{cm}$ coufferiblas tas con gee na minores drmaism - Poi procenaso há pouso va Eotes the perseationavis.

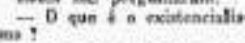
Mtuits caimn Surtre nopoes deci, new ganta-pio. 


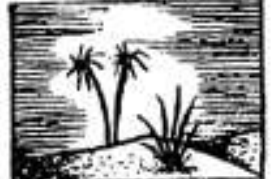
D. $\begin{aligned} & m \text { an patie gronde el- } \\ & \text { mesiata en abrizara }\end{aligned}$ brias llavit dase su gulase

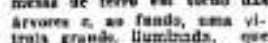
totsus sem consws o bar, prepriamente, eta of hambeso tis. ro eue thava as fundo 0 ande

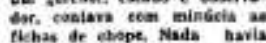

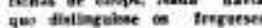

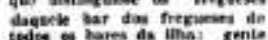

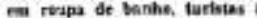
eaper ob barra, penaientatas taw hostis proviteod, Emes nuttidia era ditmics en tora

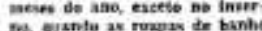

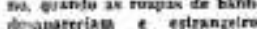

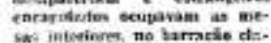
sw. intetives no barmelis cl:tande o proge on itrirenos to. teados nst redonderse. Nibo fai no inverna que vo mesims no verase cam lartie

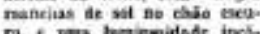
mexês, penistimite, vinas de

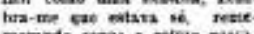
morisdo chas e cedis pase.

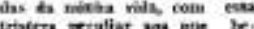

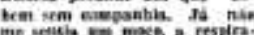
chis se ma tis tersasndo curta

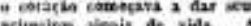
nion newem pergumbasa quan-

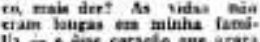
eemecas a se masifestar is ate era a reapensavet par tidus as dewhone de nim ne docarrer de timpe

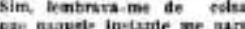

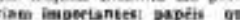

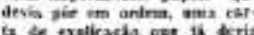

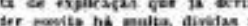
cules. Puer qee nia cheara

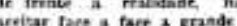

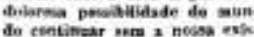
do contingar ma a nosos esh.

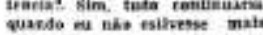

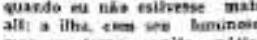
war = tarns, aevide pation

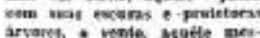
ine wals ves me raskes as fie ré, ô debinia da vids. " c c estrea, apertando entre on deties a croe dearkte pete cho-

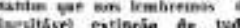
geasele tom turne o prrico pa. ree nais lange $e$ o sids, th elerna mos seis minutas hareatia e candertisule?

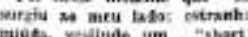

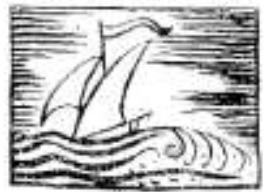

\section{A V E N T U R A}

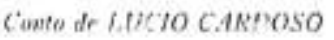

vermollibo qua the is rann entre. crdinints araga Desdllauel in tabeloess stres que tran.

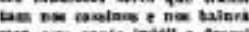

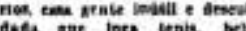

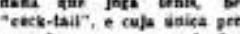

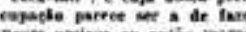

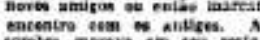
atrsites de chapein te petist of

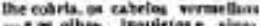
parecilem apesiefio b viotencu himinosids.

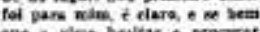
que I viser Meskar e pracw

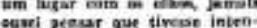

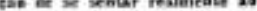
mas bese, senion-se, paik "

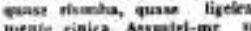

mede láb singlea t compincen.

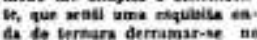

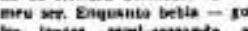
the

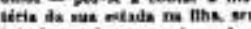
laterisu prito mar, pelou coksus

Nrom ru messa sei ne awris.

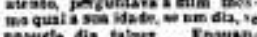
maviele dia taini. Toquan.

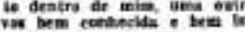
dhitemie Ragetiss milimes sem.

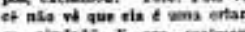

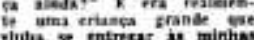
mies, que roeswon a minha po. lee imaginatio de haen

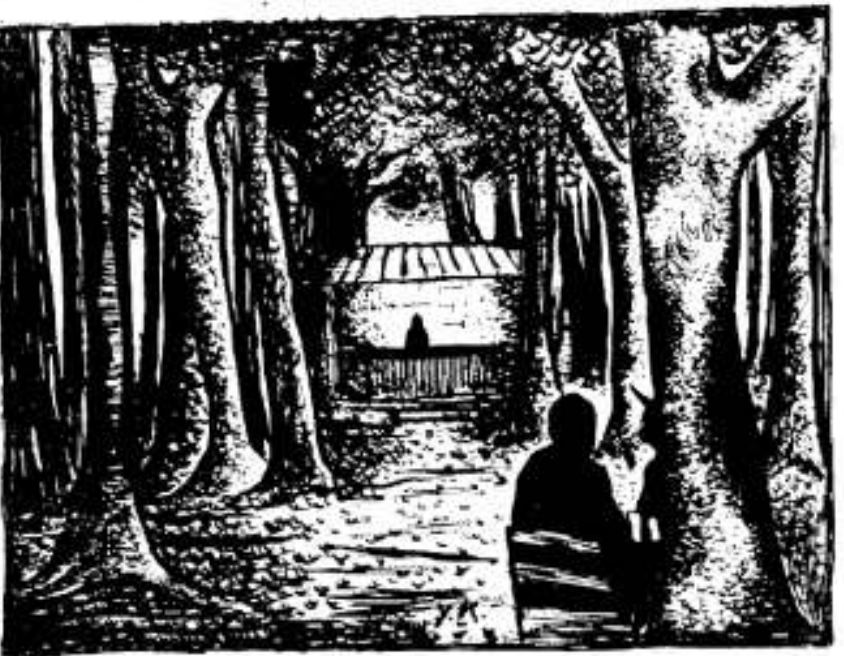

llistracto ts YLLEN KERE

principin, lashisboto-met eom

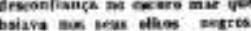

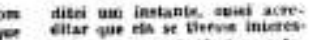

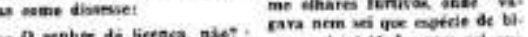

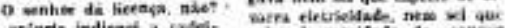

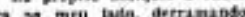
cos a grecizitach de mou ser. 16. A chape vie mothath dian

Oh, que dessutret - $n$

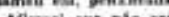

Minnti que nao era madx. - 5 entame meo seasar ae. taiso desta patedra, Ventre aqui todis os diac 0 pition. Fande, max ja é quase our rito park mim,

Ceacerdel ear ere a melie caler de moritade, de ance Mepentiaseneme moti-a azirs: : mar parcese-me muia Saler mais forke, nae mait de

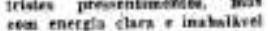
cenfiancto to minkm powibi idates As nik, on haverm stare nease methrets of vside. sent I. the peyarne patie that

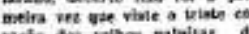

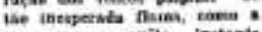
que sovern zquelt instagite

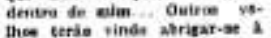

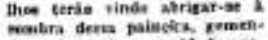
noibra dens paincich. rementdida. A inpesiliatidade As derste coda ve wath prixa.

dall mais 4 motide

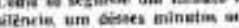

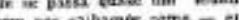

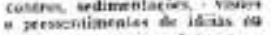
cratimeniss nowis e fatires

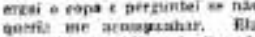
Nio sor quansos thepry tomateon frinia s.nterned.mes c

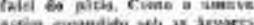

maquile pequene retingule an

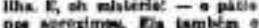

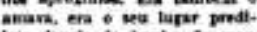
leis depelt do banhe de war.

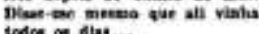
- Setancas: - pertumiel ue unis afolic do-me monzamente. Mees wisbar. - do tin do pasis, sib ell venhe subi, ste o gerente fle

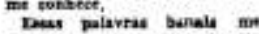
parectran ama expleacha di. mesta pars mient men sento Ae onnfance inundea-rae

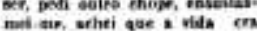

- Puine boje manas:

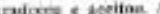

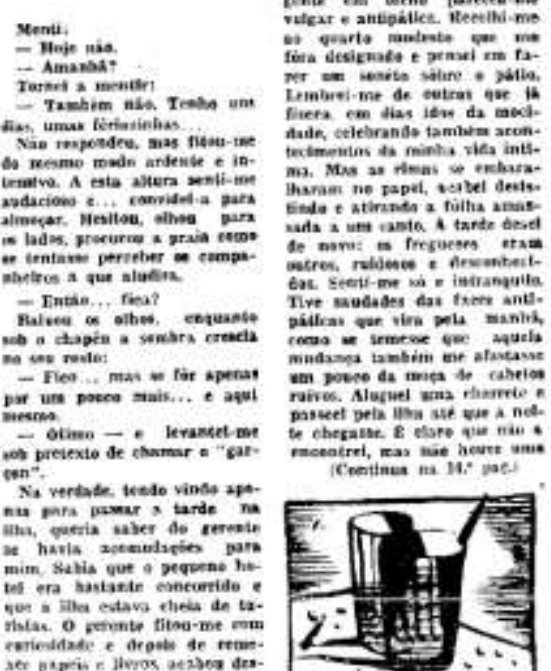

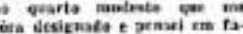

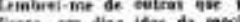
Aaid, celeornonds tamibra aroi m3. Mos as Hens of rebras Eida $t$ atirinds a fiilta anas.

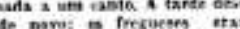

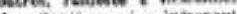
Tre audoces das trers wnt

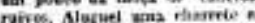

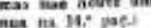

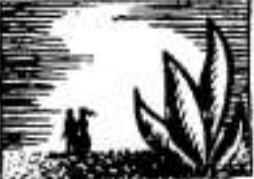

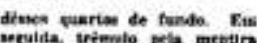

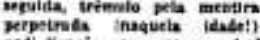

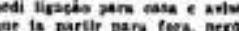

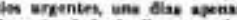

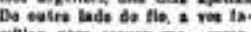

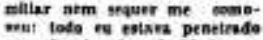
nasuela sianglat claristade yet omige. do vou bullit quente. Que cell co a respetile do que cass gumlitader, mus naliwes - tnite que cosm nde critame

Voluei s sicur.me sels a pat.

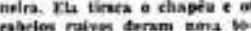
nalldale sa neu rosto mase

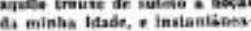
enente o siagser min quelatio e duratir moth mara, etris, en

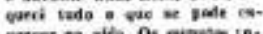
cercer ta nis. Os nimuin to. cos

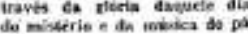
Acobacta a metrikies. weli qae Coorpento da separache whis urta colsa isplasivel k. to ine carazetin mars eolced-ts onir. on wus eleies Fitod-me teu-ne a wase?

Tiu berrot supernitions one

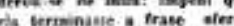
dime pan levis on parte.

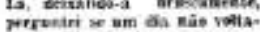
its ao vin sarrin the

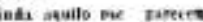

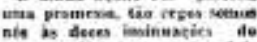

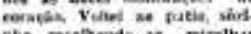

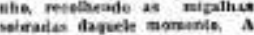
ginle en lectio tareve ne 
Domingo, 23-7.1950

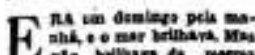

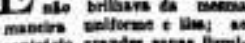

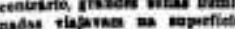
medaluda jeso reato, eestras.

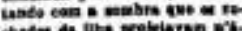
re. Airum amsncader the pedrat pelo allise umperel, ne

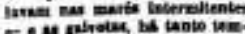
- as aboter, bs tanto in:

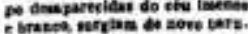
thrmian, necheads ose it ar. themian, recticach of

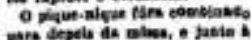

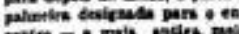

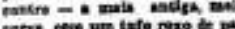

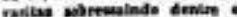
mplichos aegres - duas dus mi.

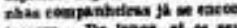
trans. Do lacke, it wo neu

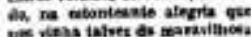

phiacers: La! - erianas ander quen men stram. que irese

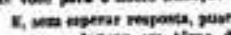
nam-se odetcar en tirne a mim, saltando o basenes pit. - os Lta, cane $t$ llade os se

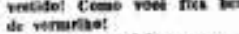
unta sate en trovia, misterieas mente cabirie ceser am tiirda.

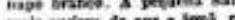
pelie a pergenta: -0 ouc

Alacka Lia?

- Viges o murances - ain 13. Mopredento o pue

- ot et alors werango Tilian

Crlonate a crita jumo is at-

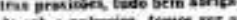

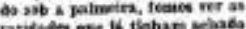
ins arraveida, wikuman een. thas amaradas. Cans on trit

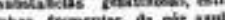

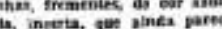

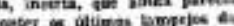
meit selonarin

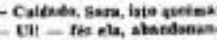

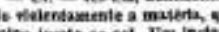

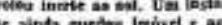

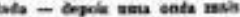
terke lewo-2, incurperande-a de aow ao neu indera
nundo excero e liguido

- Adrus, srates a peeeens kars nas a ceda soe in re: An dow

wisis e eeso as nescin pes.

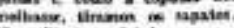

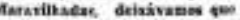

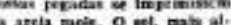

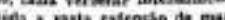

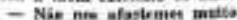
- reapes es - tabors es atato

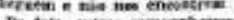

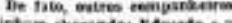

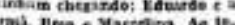

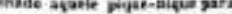

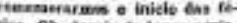
ha Oa, oepir de lente vnie sitreew par isertade, ar lime. - vehie sos arslast come a ins mon paewers um meanide

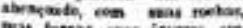
was fareas, sas irveres nia
LRTRAS TARTES

\section{SIMPLES ENCONTRO}

Conto de LUCIO CARDOSO

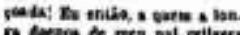

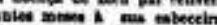

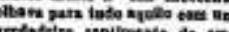

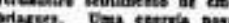

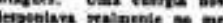

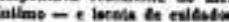

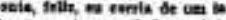

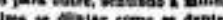

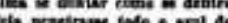
ceaso corrianos on

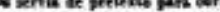
rent

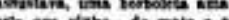

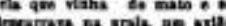

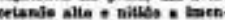
4 vacidet do ces sin, iewirs-met we Eauard.

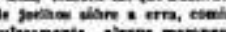
lowark Arsapereetiso as langes as prat

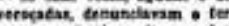
ear dos primutiras pilandas tes. comernas. Mandina wabra.

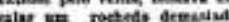
ingrear gar at nas tircas. $E$ an itatio de lads, coeve a

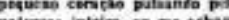

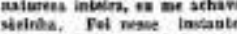

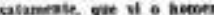

Vleserice. In mapes, sits

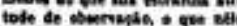

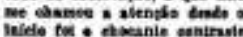
qoe oferecia i paluasen: nb:

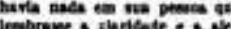
mis ane ous setesns, as cop. trirse poilw de cremmente at geete, cickeats mas os

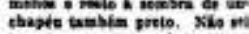
porsoe, ase macis on cete-

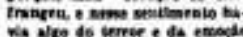

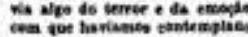

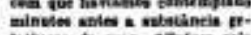

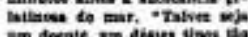
sm deente, sin disies vipas id cemans gas procuras o ctim

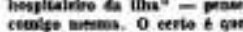

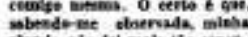

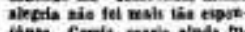

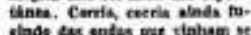
slade ens andas get tinhism

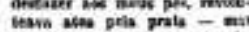
jic sears a fieme to esirant

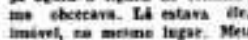
imiveh, na meine lesar. Mel Ders, pamals

In penisiot

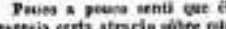
cqee new dites me Hasam te preseriacia. Quase sea garice.

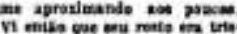
te o nevise.

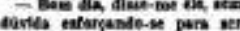
tecelletedr.

- Bow da - mapaedl es.

- Crase at alame reces -

vergaces int

- Bealle sesel E viera ta.

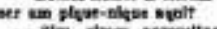
manti.

At mesmo leape gue es tala.

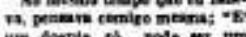
um boente os polo on un

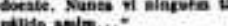

- E que tastil noek, cerrendof

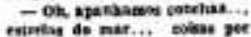
si...

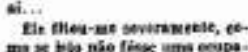
de para ana menten to minita

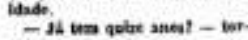

- Voe tazi-las davil a trés dast Alt - ais eare ma mads.

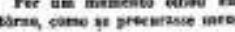

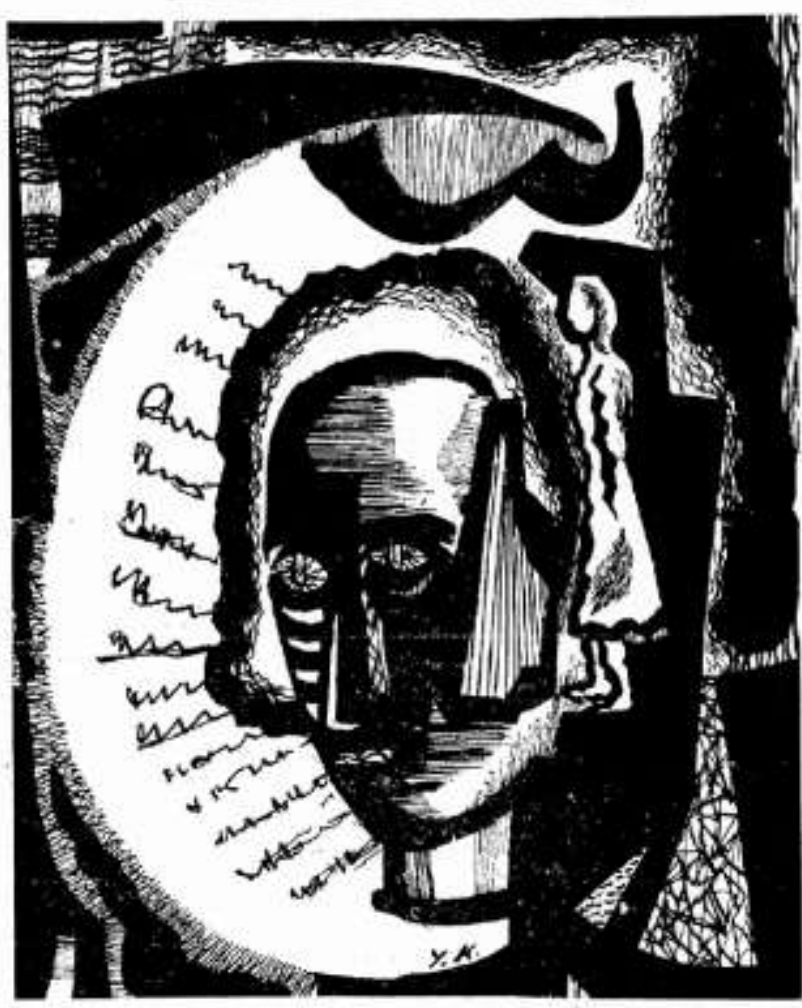

Drienhin din YLLEN KERR
Pigins - 9

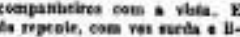

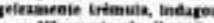

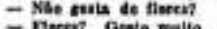
rerpeadi.

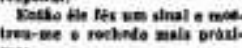
- Ala con tien ho ama, me- ving crompeteder. Mle curedilit, ebervel o rin petres Ele anyeu-se on mes noto so - Erat i ama papeula ope

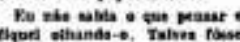

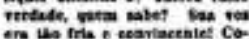

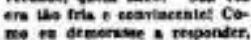

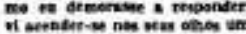

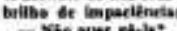

- Qevon... mat suet enih. - Pue iris dagertes eastus. degat nis ove ve

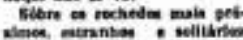

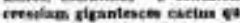
- vento do mar acelises. Sia geete minata, nag ad on aetrtre flos vas papesta azul od apebas wir o miesteria ta quele hoeste we airiala, Acrom-

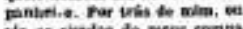

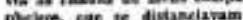
0 heern camintava na a nha ferets, carnads, oflegante

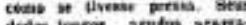

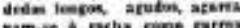
Kas tardos auito on sure che

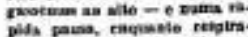
jish pasas, caquesie retiptra ave se tevertlaxns intera,

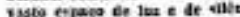

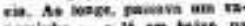
jarnitihe - O a cal tains,

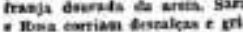
tavam desion iter selado vas.

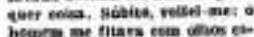
onde mis a sopretar perianat.

- Ali - montroes ane do. civie.

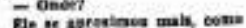
yon mentracome a vier.

- All, bes sil.

Ohei at nare - e de repeai

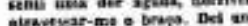
wribe, wes cangersider of lies c. trivende-e, of een

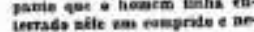
cre espenhe de cactus. - o vmitient - ese

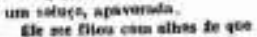
jamais me menererd, Lis duNat to cre temes que the re velane cors isse wasar, nat ifce mals devida de war ee bits.

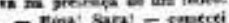

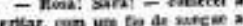
ime necerer pete lanpo. Be bes nalio n haserm ne ahis. low \& devers pelan pelras, car. esiu, de. apantase cen ath

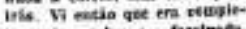

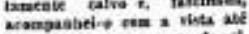

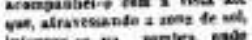
otempartess pata stapet. 